\title{
Radium and Radon in Ground Water in the Chickies Quartzite, Southeastern Pennsylvania
}

By Lisa A. Senior and Karen L. Vogel

U.S. GEOLOGICAL SURVEY

Water-Resources Investigations Report 92-4088

Prepared in cooperation with the

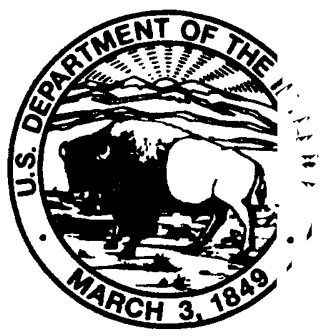

PENNSYLVANIA DEPARTMENT OF ENVIRONMENTAL RESOURCES, BUREAU OF TOPOGRAPHIC AND GEOLOGIC SURVEY BUREAU OF RADIATION PROTECTION 


\title{
U.S. DEPARTMENT OF THE INTERIOR
}

\section{BRUCE BABBITT, Secretary}

\author{
U.S. GEOLOGICAL SURVEY
}

Gordon P. Eaton, Director

For additional information write to:

District Chief

U.S. Geological Survey, WRD

840 Market Street

Lemoyne, Pennsylvania 17043-1586
Copies of this report can be purchased from:

U.S. Geological Survey

Earth Science Information Center Open-File Reports Section Box 25286, MS 517 Denver Federal Center Denver, Colorado 80225 
Abstract

Introduction .1

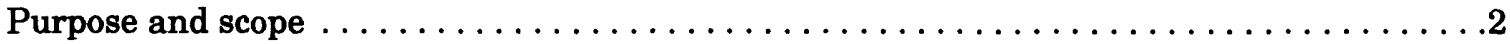

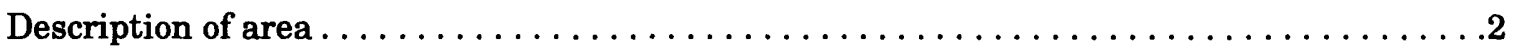

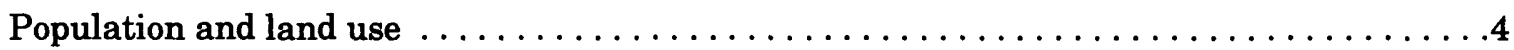

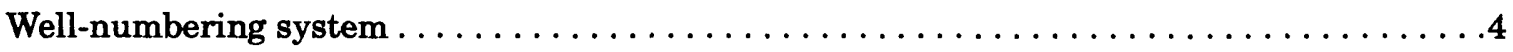

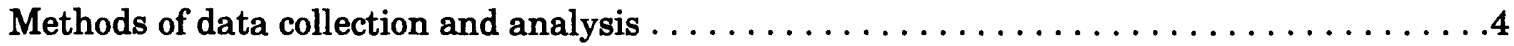

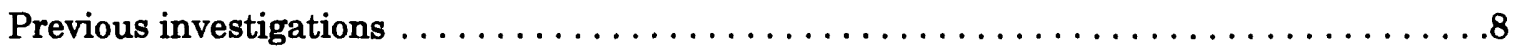

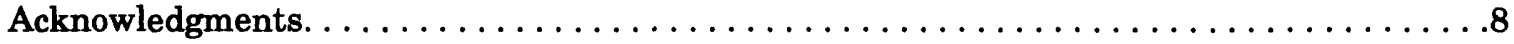

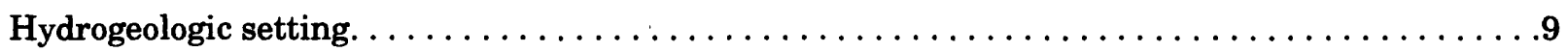

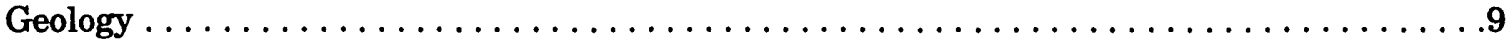

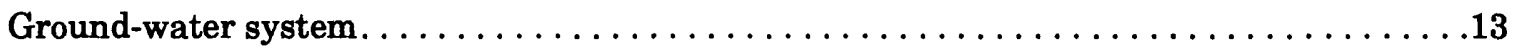

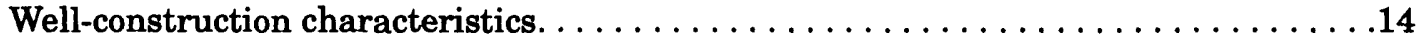

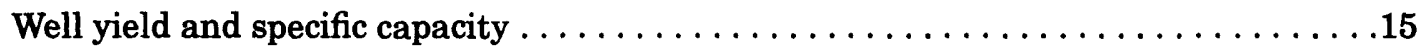

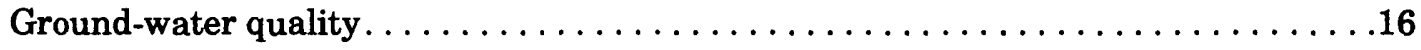

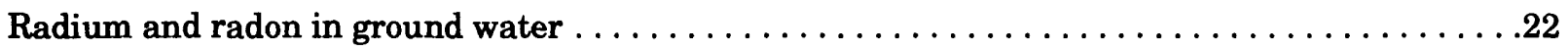

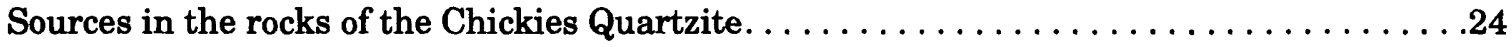

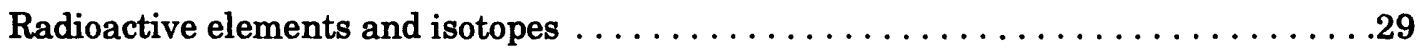

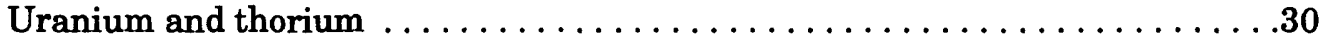

$\mathrm{U}-238$ and $\mathrm{Th}-232$ decay series radionuclides. . . . . . . . . . . 35

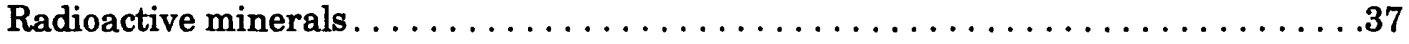

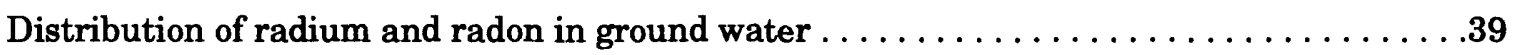

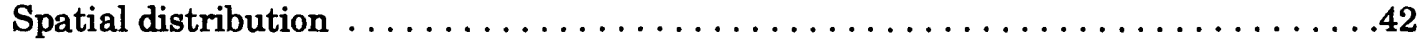

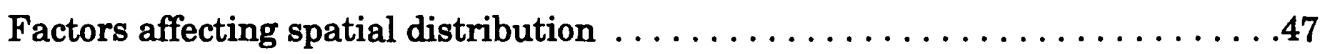

Lithology ...........................

Chemistry of ground water. . . . . . . . . . . . . . . . 49

Aquifer and well-construction characteristics..............59

Hydrogeologic setting . . . . . . . . . . . . 60

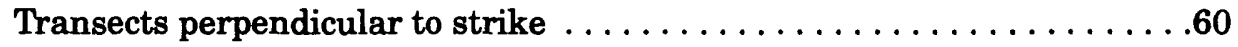

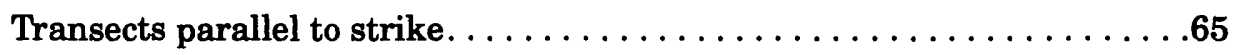

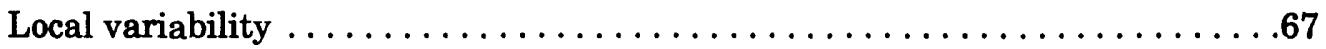

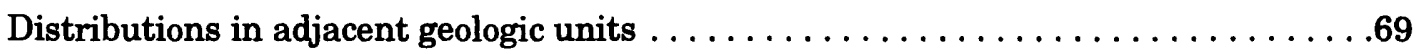

Distributions in other quartzites in the Piedmont . . . . . . . . . . . . . . 71

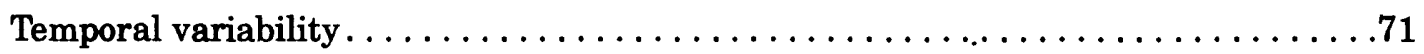

Conceptual model of radium and radon in ground water $\ldots \ldots \ldots \ldots \ldots \ldots \ldots \ldots .74$

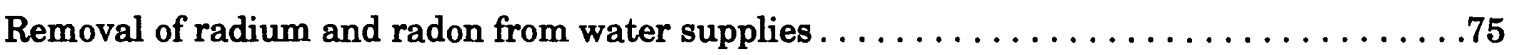

Summary . . . . . . . . . . . . . . . . . . . . . .

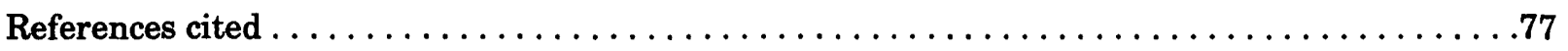

Glossary . . . . . . . . . . . . . . . . . . .

Appendix.--Caliper and natural gamma logs for wells in the Chickies Quartzite, southeastern Pennsylvania .124 


\section{PLATE}

[In pocket]

Plate 1.--Map showing outcrop of Chickies Quartzite and location of selected wells and springs in Berks, Bucks, Chester, Lancaster, Montgomery, and York Counties, Pennsylvania

\section{FIGURES}

Figure 1.--Map showing location of the Chickies Quartzite, southeastern

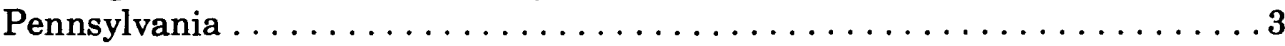

2.--Generalized stratigraphy of lower Ordovician and older rocks in northcentral Chester County, Pennsylvania . . . . . . . . . . . . . . . . 10

3-4.--Piper diagrams showing chemical composition of ground water in the:

3.--Quartzite, conglomerate, slate, and slate-quartzite lithologies of the Chickies Quartzite . . . . . . . . . . . . 19

4.--Eastern, central, and western areas of outcrop of the Chickies Quartzite.........................20

5.--Sketch showing uranium-238 and thorium-232 decay series $\ldots \ldots \ldots \ldots \ldots \ldots 23$

6.--Caliper, natural-gamma-ray, and lithologic logs for well $\mathrm{CH}-3219 \ldots \ldots \ldots \ldots \ldots 25$

7.--Natural-gamma-ray logs for wells drilled into light-colored quartzite, dark-colored quartzite, and conglomerate of the Chickies Quartzite . . . . . . 26

8.--Natural-gamma-ray logs for wells LN-1713, CH-3122, and CH-3188 drilled at the Chickies Quartzite contact with underlying Precambrian

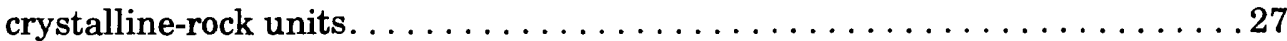

9.--Natural-gamma-ray logs of wells drilled into the Harpers Phyllite

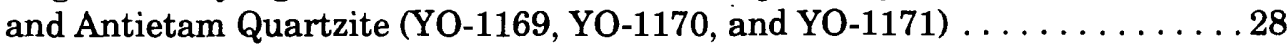

10.--Map showing quarries and outcrop sites for rock samples of the Chickies Quartzite. .............................. 31

11.--Natural-gamma-ray logs of wells $\mathrm{CH}-3315$ and $\mathrm{CH}-3122 \ldots \ldots \ldots \ldots \ldots \ldots$

12.--Photomicrograph of zircon with metamict core from well $\mathrm{CH}-3122$ cuttings . . . . . 37

13.--Autoradiographs and thin sections of heavy-mineral separates from well $\mathrm{CH}-3122$ cuttings . . . . . . . . . . . . . . . . . . . . . . . 38

14-15.--Graphs showing:

14.--Cumulative frequency of radium-226 and radium-228 activities in ground water in the Chickies Quartzite . . . . . . . . . 40

15.--Cumulative frequency of radon-222 and the sum of radium-226 and radium-228 activities in ground water in the Chickies Quartzite .............................41 
Figure 16-18.--Boxplots showing:

16.--Distribution of radium-226 and radium-228 in ground water from the eastern, central, and western areas of Chickies Quartzite ..........................44

17.--Distribution of radon-222 and the sum of radium-226 and radium-228 in ground water from the eastern, central,

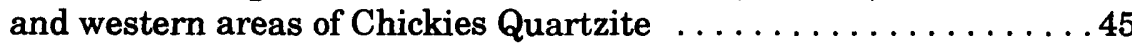

18.--Distribution of radium-226, radium-228, and radon-222 in ground water from the conglomerate, quartzite, and slate lithologies of the Chickies Quartzite . . . . . . . . . . . 48

19.--Piper diagram comparing chemical character of groud water with and without elevated radium activities from wells in the Chickies Quartzite. . . . . . . . . . . . . . . . . . . . . 50

20-23.--Graphs showing:

20.--Relation between $\mathrm{pH}$ and radium-226 and radium-228 for ground water in the quartzite and conglomerate

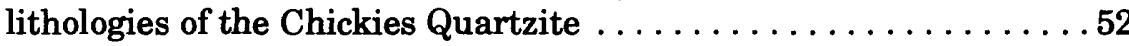

21.--Relation between the sum of radium-226 plus radium-228 and $\mathrm{pH}$ for ground water in the Chickies Quartzite. . . . . . . . 53

22.--Relation among dissolved organic carbon, $\mathrm{pH}$, radium-226, and radium-228 in ground water in the Chickies Quartzite. . . . . 55

23.--Relations among barium, sulfate, radium-226, and radium-228 in ground water in the Chickies Quartzite . . . . . . 56

24.--Boxplots showing distribution of $\mathrm{pH}$, dissolved organic carbon, sulfate, and barium in ground water from the conglomerate, quartzite, and slate lithologies of the Chickies Quartzite . . . . . . . . 58

25-29.--Maps showing:

25.--Location of transects of sampled wells

26.--Geology and location of selected wells, Welsh Mountain,

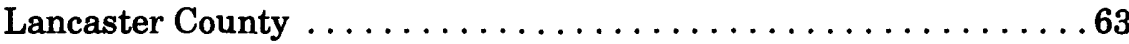

27.--Radium and radon activities and $\mathrm{pH}$ in ground water and schematic geologic sections perpendicular to strike, Welsh Mountain, Lancaster County. . . . . . . . . . . . . 64

28.--Geology and locations of selected wells, Barren Hills, Chester County . . 65

-29.--Radium and radon activities and $\mathrm{pH}$ in ground water and schamatic geologic sections parallel to strike, Barren Hills, Chester County

30.--Graph showing relations among radon-222, radium-226, and radium-228 activities; $\mathrm{pH}$; sulfate; and ammonium concentrations;

and depth to water in well $\mathrm{CH}-3335$, September 1988 to November 1989 . . . 73 
Table 1.--Average bulk composition of 26 rock samples of the Chickies Quartzite, Lancaster County, 1 rock sample from the type locality and 3 rock samples from Bucks and Montgomery Counties

2.--Number of water-bearing zones per 100 feet of uncased borehole for 151 wells drilled in the Chickies Quartzite . . . . . . . . . . . 13

3.--Range and median of depth and casing length of wells drilled in the Chickies Quartzite . . . . . . . . . . . . . . . . . . . . . . . . . . . . 14

4.--Range and median of reported yield and specific capacity of wells drilled in the Chickies Quartzite . . . . . . . . . . . . . . . . . . . . . 15

5.--Range and median concentrations of selected chemical constituents and properties for 160 well-water samples from the Chickies Quartzite . . . . . . . . 17

6.--Spearman rho correlations for selected chemical constituents in 160 well-water

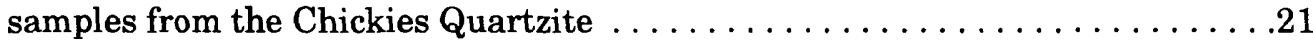

7.--Average uranium and thorium content of the earth's crust and some

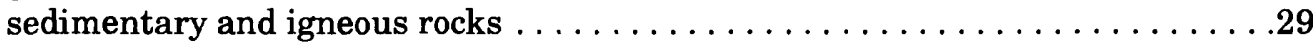

8.--Uranium and thorium content of well cuttings and rock samples determined by neutron activation analysis $\ldots \ldots \ldots \ldots \ldots \ldots \ldots \ldots \ldots \ldots$

9.--Summary of uranium and thorium content of well cuttings and rock samples of the conglomerate, quartzite, and slate lithologies of the Chickies Quartzite . . . . . . . . . . . . . . . . . . . . . . . 33

10.--Solid-phase activities of uranium-238 and thorium-232 series radionuclides and potassium- 40 determined by gamma-ray spectrometry of well-cutting samples from the Chickies Quartzite. . . . . . . 35

11.--Radium-226 and radium-228 activities, calculated uranium-238 and thorium-232 activities, and percent radium-226 and radium-228 loss for six well-cutting samples from the Chickies Quartzite . . . . . . . . . 36

12.--Range and median values of radiochemical constituents for water samples from 160 wells in the Chickies Quartzite . . . . . . . . . . . . . . . 39

13.--Distribution of radium and radon-222 activities in ground water of the

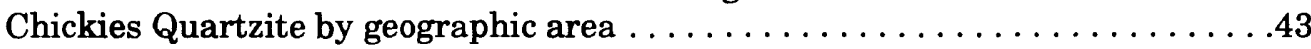

14.--Distribution of radium and radon-222 activities in ground water of the Chickies Quartzite by county . . . . . . . . . . . . . . . . . . . . . . . .46

15.--Correlations among activities of radium-226 and radium-228 and chemical constituents and properties significant at the 95-percent-confidence interval for ground-water samples from 160 wells in the Chickies Quartzite. . . . . . . . . . . . . . . . . . 5

16.--Correlations between radon-222 and chemical constituents and properties significant at the 95-percent-confidence interval for ground-water samples from 160 wells in the Chickies Quartzite . . . . . . . . . . . . .59

17.--Activities of radium-226, radium-228, and radon-222, and concentrations of selected chemical constituents and properties in water from six sets of wells drilled in close proximity in the Chickies Quartzite . . . . .68 
Table 18.--Radium-226, radium-228, and radon-222 activities and uranium concentrations in ground water from geologic units adjacent to the Chickies Quartzite

19.--Activities of radium-226, radium-228, and radon-222 and concentrations of selected dissolved constituents and properties of water from wells in the Chickies Quartzite sampled more than once . . . . . . . . 72

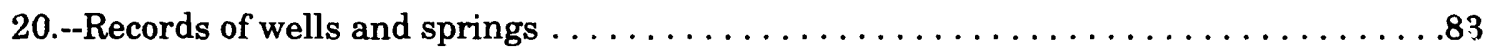

21.--Physical properties and chemical analyses for major ions, selected minor ions, nutrients, and dissolved organic carbon in ground water in the Chickies Quartzite and adjacent geologic units. . . . . . . . . 9

22.--Chemical analyses of radionuclides in ground water in the Chickies Quartzite and adjacent geologic units .110 


\section{CONVERSION FACTORS, VERTICAL DATUM, AND ABBREVIATED WATER-QUALITY UNITS}

Multiply

inch (in.)

foot (ft)

mile (mi)

square mile $\left(\mathrm{mi}^{2}\right)$

gallons per minute (gal/min)

gallon (gal)

gallon per minute per foot $[(\mathrm{gal} / \mathrm{min}) / \mathrm{ft}]$

picocuries per liter ( $\mathrm{pCi} / \mathrm{L})$
By

Length

25.4

0.3048

1.609

Area

2.590

Flow

0.06309

0.00006309

Volume

3.785

0.207

3,785

Radioactivity

0.037

1.46
To obtain

millimeter

meter

kilometer

square kilometer

liter per second

cubic meter per second

liter

liter per second per meter

milliliter becquerel per liter

micrograms per liter as uranium-natural

\section{Other Abbreviations}

micrograms per liter $(\mu \mathrm{g} / \mathrm{L})$

micrometer $(\mu \mathrm{m})$

milliequivalents per liter (meq/L)

milligrams per liter (mg/L)

Temper ature in degrees Celsius $\left({ }^{\circ} \mathrm{C}\right)$ can be converted to degrees Fahrenheit $\left({ }^{\circ} \mathrm{F}\right)$ as follows:

$$
{ }^{\circ} \mathrm{C}=5 / 9\left({ }^{\circ} \mathrm{F}-32\right)
$$

Sea level: In this report "sea level" refers to the National Geodetic Vertical Datum of 1929 (NGVD of 1929) -- a geodetic datum derived from a general adjustment of the first-order level nets of both the United States and Canada, formerly called Sea Level Datur of 1929. 


\title{
RADIUM AND RADON IN GROUND WATER IN THE CHICKIES QUARTZITE, SOUTHEASTERN PENNSYLVANIA
}

\author{
By Lisa A. Senior and Karen L. Vogel
}

\begin{abstract}
The Chickies Quartzite, a Lower Cambrian-age formation comprised of quartzite and slate overlying a basal conglomerate, forms narrow ridges and crops out discontinuously over 112 square miles in the Piedmont physiographic province of southeastern Pennsylvania. The formation is a low-yielding, fracturedrock, water-table aquifer recharged primarily by local precipitation. It is the sole source of water supply for thousands of domestic users. Ground water in the Chickies Quartzite generally is soft and acidic.
\end{abstract}

During 1986-88, the U.S. Geological Survey sampled water from 160 wells that penetrate the Chickies Quartzite to determine the magnitude and distribution of radium-226 (Ra-226), radium-228 (Ra-228), and radon-222 (Rn-222) activities in ground water in the formation and to characterize the geochemical environment associated with elevated activities of radium $(\mathrm{Ra})$. In addition, $28 \mathrm{wells}$ penetrating adjacent geologic units and 1 well in the Hardyston Quartzite were sampled to determine relative background $\mathrm{Ra}$ and $\mathrm{Rn}-222$ activities in ground water. Analyses included determination of activities of dissolved Ra-226, Ra-228, and Rn-222, and concentrations of dissolved uranium (U), dissol rad organic carbon (DOC), and major and minor dissolved inorganic ions. Rock samples were analyzed for $U$ and thorium (Th) and geophysical logs were run to determine sources of Ra and Rn-222 in the Chickies Quartzite. Activities of up to $41 \mathrm{pCi} / \mathrm{L}$ (picocuries per liter) for $\mathrm{Ra}-226,160 \mathrm{pCi} / \mathrm{L}$ for $\mathrm{Ra}-228$, and $32,300 \mathrm{pCi} / \mathrm{L}$ for $\mathrm{Rn}-222$ were measured in ground water in the Chickies Quartzite. Forty-seven percent of the samples contained $\mathrm{Ra}-226$ and $\mathrm{Ra}-228$ activities greater than $5 \mathrm{pCi} / \mathrm{L}$. Median activities measured wore $1.2 \mathrm{pCi} / \mathrm{L}$ for Ra-226, $2.6 \mathrm{pCi} / \mathrm{L}$ for $\mathrm{Ra}-228,4.2 \mathrm{pCi} / \mathrm{L}$ for combined $\mathrm{Ra}-226$ and $\mathrm{Ra}-228$, and 2,400 $\mathrm{pCi} / \mathrm{L}$ for $\mathrm{Rn}-222$. Ra-228 activity exceeded Ra-226 activity in about 92 percent of 100 water samples; the median Ra-228/Ra-226 activity ratio was 2.4 . Ra-228/Ra-226 activity ratios commonly were greater in ground water than calculated $T h / U$ ratios in rock samples, suggesting preferential leaching of Ra-228 from aquifer solids. Of ground water in the adjacent geologic units, the highest activities (up to $2.9 \mathrm{pCi} / \mathrm{L}$ for Ra-226, $12 \mathrm{pCi} / \mathrm{L}$ for $\mathrm{Ra}-228$, and $25,300 \mathrm{pCi} / \mathrm{L}$ for $\mathrm{Rn}-222$ ) were measured in ground water in the Harpers Phyllite and Antietam Quartzite.

Nonparametric (Spearman rho test) statistical correlations show that the activity of dissolved $\mathrm{Rr}$ is inversely related to $\mathrm{pH}$ and directly related to concentrations of total dissolved solids, DOC, barium, and sulfate. Low $\mathrm{pH}$ decreases adsorption of $\mathrm{Ra}$ onto the aquifer matrix. The other factors may favor $\mathrm{Ra}$ mobility by enhancing complexation or increasing solubility. Rn-222 activity does not correlate with and is not supported by the activity of its parent, Ra-226, in solution. Ra-226 activity correlates positively, but. weakly, with $U$ concentrations. Ra-226 does not appear to be supported by its parent, U-238, in solution.

Observed distributions of Ra-228, Ra-226, and Rn-222 activities in ground water in different lithologies of the Chickies Quartzite reflect different geochemical controls on adsorption and distribution of parent thorium-232 (Th-232) and uranium-238 (U-238) in the formation. Radium activities were greatest in acidic ground water in the conglomerate and quartzite (median $\mathrm{pH}$ of 5.0 and 5.2, respectively) and least in the more neutral water in the slate (median $\mathrm{pH}$ of 6.4). For ground water in the conglomerate, quartzite, and slate, respectively, median activities measured were: $1.3,1.5$, and $0.2 \mathrm{pCi} / \mathrm{L}$ for $\mathrm{Ra}-226$; and $3.7,2.5$, and $1.0 \mathrm{pCi} / \mathrm{L}$ for Ra-228. Natural-gamma-ray geophysical logs and results of rock analyses indicate that the conglomerate may contain more $T h$ and $U$ than the quartzite and that the conglomerate may be more enriched in Th with respect to $U$ than the quartzite; Th and $U$ distribution in both lithogies is variable. Median $\mathrm{Rn}-222$ activities in ground-water samples generally are greater progressively from the slate $(1,400 \mathrm{pCi} / \mathrm{L})$ to the quartzite $(2,000 \mathrm{pCi} / \mathrm{L})$ to the conglomerate $(3,400 \mathrm{pCi} / \mathrm{L})$ and may reflect difference in $\mathrm{U}$ content of the lithologies.

Ra-226, Ra-228, and Rn-222 activities in ground water vary locally and temporally. Lithology controls the geochemical environment, topography, and ground-water flow paths, and, therefore, the spatial distribution of $\mathrm{Ra}$ and $\mathrm{Rn}-222$ activities. Temporal variations are seasonal; maximum $\mathrm{Ra}$ and $\mathrm{Rn}-222$ activities in ground water occur with water-table lows in autumn and minimum $\mathrm{Ra}$ and $\mathrm{Rn}-222$ activities occur with water-table highs in the spring. 


\section{INTRODUCTION}

In 1985, during routine sampling of public supply wells, the Pennsylvania Department of Environmental Resources (PaDER) discovered activities of radium (Ra) that exceeded the U.S. Environmental Protection Agency (USEPA) maximum contaminant level (MCL) ${ }^{1}$ for drinking water (U.S. Environmental Protection Agency, 1986) of $5 \mathrm{pCi} / \mathrm{L}$ (picocuries per liter) in water samples from several wells drilled into the Chickies Quartzite. The MCL is for the sum of the activities of Ra isotopes, of which radium-226 (Ra-226) and radium-228 (Ra-228) are the most abundant in nature. Ground water in the Chickies Quartzite is the sole source of supply for thousands of private users and a few public-supply systems. According to Cothern (1987), ingestion of water containing elevated activities of $\mathrm{Ra}$ can cause bone cancer. The health effects of ingesting drinking water that contains elevated concentrations of radon-222 ( $\mathrm{Rn}-222)$, a radioactive isotope produced from the radioactive decay of Ra-226, are not clearly known. Degassing of Rn-222 from well water into closed buildings may pose a health risk (lung cancer) by inhalation (Cothern, 1987).

During 1986-89, the U.S. Geological Survey (USGS), in cooperation with the PaDER Bur ?au of Topographic and Geologic Survey and PaDER Bureau of Radiation Protection, conducted a study of the occurrence of Ra-226, Ra-228, and Rn-222 in ground water in the Chickies Quartzite to determine the distribution and magnitude of elevated $\mathrm{Ra}$ and $\mathrm{Rn}$ activities. The investigation included the collection and analysis of ground-water and rock samples.

\section{Purpose and Scope}

This report presents and summarizes data on the occurrence of Ra-226, Ra-228, Rn-222, uranium (U), and major and minor dissolved constituents in ground-water samples collected frcm the Chickies Quartzite and adjacent formations during 1986-89. It presents data on U and thorium (Th) in the rocks of the Chickies Quartzite as well as results of data analysis by statistical and graphical methods and describes a conceptual model for the occurrence of Ra in ground water. The report identifies the distribution and magnitude of the $\mathrm{Ra}$ and $\mathrm{Rn}$ anomalies in ground water of the Crickies Quartzite and characterizes the geochemical and hydrologic environments associated with elevated $\mathrm{Ra}$ and $\mathrm{Rn}$ activities in ground water.

\section{Description of Area}

The Chickies Quartzite crops out discontinuously over $112 \mathrm{mi}^{2}$ in the Piedmont Physiogr $r$ phic Province of southeastern Pennsylvania (fig. 1). Trending east-northeast, the formation crops out in eight counties in Pennsylvania: Adams, York, Lancaster, Berks, Chester, Montgomery, Philadelphia, and Bucks. The Chickies Quartzite forms a series of discontinuous narrow ridges that define tr ree distinct and separate (fig. 1) structural and lithologic areas: a western area in Adams, York, anf western Lancaster Counties; a central area in eastern Lancaster, Berks, and Chester Counties: and an eastern area in Montgomery, Philadelphia, and Bucks Counties. Generally, the ridges formed by the Chickies Quartzite are flanked by stratigraphically younger carbonate rock underlying valleys and by stratigraphically older, crystalline rock underlying rolling uplands.

\footnotetext{
1 The USEPA in 1991 proposed a MCL for radium of $20 \mathrm{pCi} / \mathrm{L}$ for $\mathrm{Ra}-226$ or $20 \mathrm{pCi} / \mathrm{L}$ for $\mathrm{Ra}-228$ in drinking water.
} 


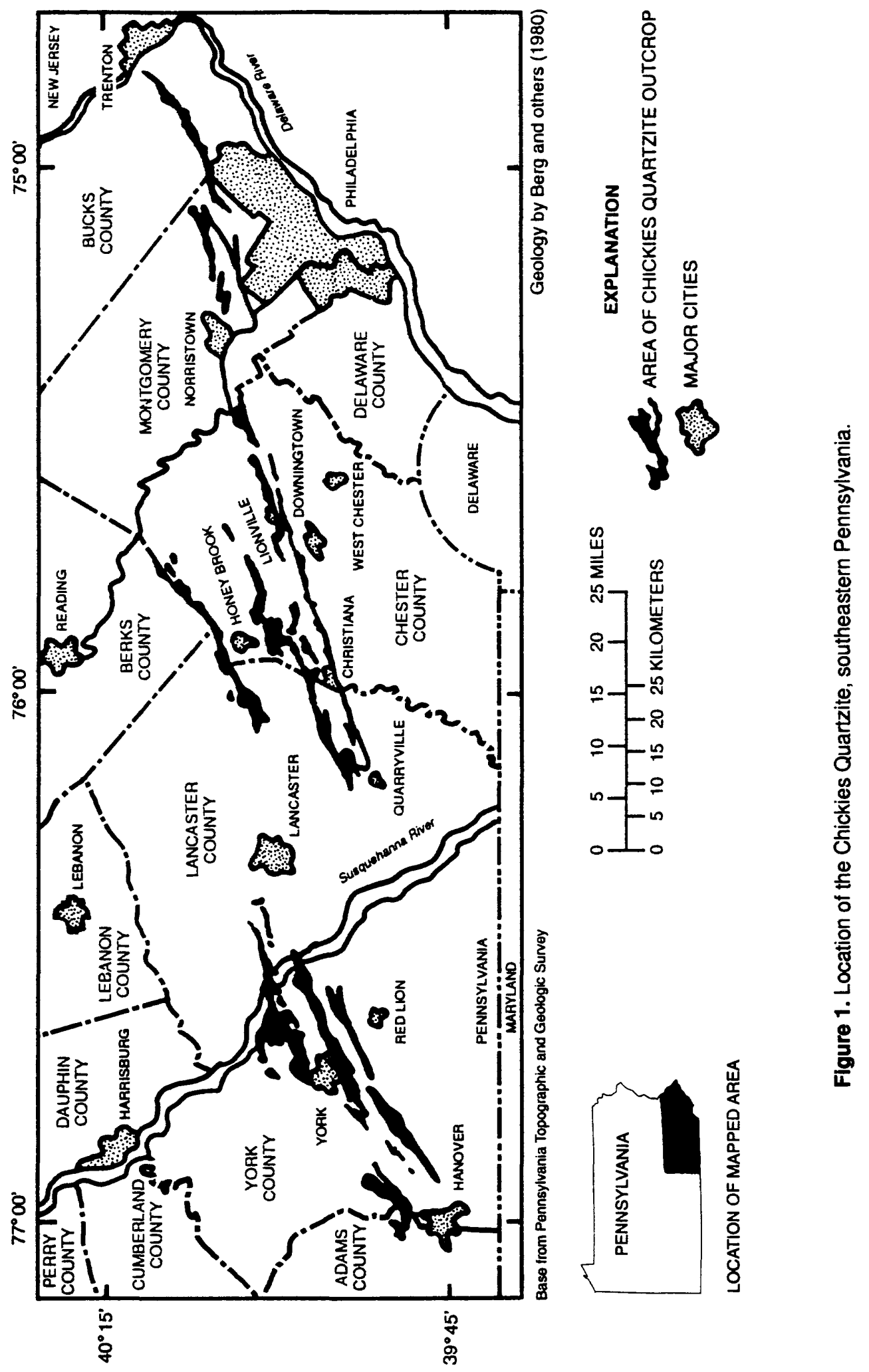




\section{Population and Land Use}

The Chickies Quartzite crops out near areas of high- and low-density population. Several tens of thousands of people rely on ground water from the Chickies Quartzite for their water supply. Economic use of rock and minerals of the Chickies Quartzite includes past mining for iron ore and clay and present quarrying for building stone and aggregate.

In the eastern part of the study area, the formation underlies the northwestern edge of the. City of Philadelphia and its associated suburbs. The eastern part of the study area is the most urbanized, and most of the area's water needs are met by public surface-water supplies and wells in aquifers other than the Chickies Quartzite. Golf courses, country clubs, and a few domestic wells withdraw ground water from the Chickies Quartzite for irrigation, swimming pools, and domestic use.

The central and western parts of the study area are changing rapidly, with farms and fore giving way to residential, commercial, and industrial development. Until recently, ridges underlain by the Chickies Quartzite were forested and sparsely populated because of their relatively steep slopes and thin, poor soil unsuited for agriculture. Most residents rely on wells for water supply and have on-lot septic systems for disposal of waste water. The isolation of the ridges also has made them attractive sites for legal and illegal waste disposal. Two active landfills are located on the formation, one of which is in an abandoned quarry. Several inactive waste-disposal sites are on the USEPA's National Priorities List (Superfund-site designation).

\section{Well-Numbering System}

The well-numbering system in this report consists of a local well number and a siteidentification number. The local well number consists of two parts: (1) a two-letter abbreviation that identifies the county in which the well is located, and (2) a sequentially assigned number. Wells located in Berks, Bucks, Chester, Lancaster, Montgomery, and York Counties are identified by t] $\mathrm{e}$ prefixes BE, BK, CH, LN, MG, and YO, respectively. No wells were sampled in Adams or Philade'vhia Counties.

The 15-digit site-identification number is based on latitude and longitude. The first six digits are the degrees, minutes, and seconds of latitude; the next seven digits are the degrees, minutes, and seconds of longitude; and the last two digits are the sequence number. The sequence number is assigned to distinguish among sites located within a common 1-second grid block of latitude and longitude.

The combined prefix of a county abbreviation and SP denotes a spring in that county. Locations of selected wells and springs are shown on plate 1 . Construction and production data for wells and springs are listed by county and local well number in table 20.

\section{Methods of Data Collection and Analysis}

Samples of ground water were collected and analyzed for activities of dissolved Ra-226, Ra-228, and $\mathrm{Rn}-222$, and concentrations of other chemical constituents in three phases between Novemk or 1986 and September 1988. Ground-water samples were from 1 spring and 160 wells completed in the Chickies Quartzite and from 1 spring and 28 wells completed in adjacent geologic units. The first, phase of data collection was a reconnaissance to determine the extent and magnitude of elevate $\mathrm{Ra}$ activity and to define, in general terms, ground-water chemistry. Sites were selected to distribute sample collection evenly over area of outcrop, with about two wells sampled on each 7.5-minute topographic quadrangle map where the Chickies Quartzite crops out. The next two phases of data and sample collection increased the areal sampling density, increased sampling coverage in an area vhere the hydrogeology was relatively well known, and provided additional data on hydrologic and genlogic factors controlling Ra activity in ground water. Hydrologic data collected included well yield, specific

capacity, depth, length of casing, and depth to water. Geologic data included lithology, gamma-ray and other geophysical logs of wells, rock-sample analyses, and mineral identifications. Several clusters of 
closely-spaced wells were sampled to study the range of Ra activity in water from wells within a small area. Several transects of wells penetrating different intervals in the Chickies Quartzite and adjacent formations were sampled to study the lithologic and flow-path controls on Ra activity in ground water.

Most of the sampling sites were domestic wells equipped with submersible pumps. Pumping rates ranged from 2 to $9.5 \mathrm{gal} / \mathrm{min}$. All filters and treatment systems were bypassed. Wells were pumped until temperature, $\mathrm{pH}$, and specific conductance stabilized, usually 30 to 60 minutes. Probes to monitor $\mathrm{pH}$, temperature, and specific conductance were placed below the surface of a continuously overflowing sampling container supplied by the well discharge; use of the overflowing container reduced contact of the water with the atmosphere.

Field measurements of $\mathrm{pH}$, temperature, alkalinity, dissolved oxygen (DO) concentration, and specific conductance of ground-water samples were made by established methods (Wood, 1976). Alkalinity titrations were conducted to an endpoint of $4.5 \mathrm{pH}$ units and are reported as milligrams per liter of calcium carbonate $\left(\mathrm{CaCO}_{3}\right)$. Bicarbonate $\left(\mathrm{HCO}_{3}\right)$ is assumed to be the dominant component of alkalinity in dilute ground waters with neutral to acidic $\mathrm{pH}$ and (or) organic content. For water with an initial $\mathrm{pH}$ of 4.5 or less, alkalinity is reported as zero $\mathrm{mg} / \mathrm{L} \mathrm{CaCO}_{3} . \mathrm{DO}$ concentration was determined by use of the azide modification of the Winkler titration method (American Public Health Association and others, 1975).

Samples of ground water for inorganic chemical and radiochemical analysis were filtered through a $0.45-\mu \mathrm{m}$ filter. Samples for dissolved organic carbon (DOC) analysis were filtered through a $0.1-\mu \mathrm{m}$ silver filter by use of a peristaltic pump. Sample preservation included acidification for radiochemical and metals analysis, chilling for DOC analysis, and addition of mercuric chloride and chilling to $4^{\circ} \mathrm{C}$ for nutrient analysis. Concentrated hydrochloric acid was used to preserve samples for radionuclide analysis during phase one of sampling; otherwise, concentrated nitric acid was use $\mathrm{f}$ for all acidified samples. At each site, two samples for radon analysis by liquid scintillation were collected with a syringe (U.S. Environmental Protection Agency, 1978).

Analysis of ground-water samples for inorganic constituents, including nutrients, and DOC was done by the USGS National Water-Quality Laboratory by use of standard methods (Fishman and Friedman, 1989). Inorganic constituents analyzed were: calcium (Ca), magnesium ( $\mathrm{Mg})$, sodium $(\mathrm{Na})$, potassium $(\mathrm{K})$, iron $(\mathrm{Fe})$, manganese $(\mathrm{Mn})$, barium $(\mathrm{Ba})$, chloride $(\mathrm{Cl})$, fluoride $(\mathrm{F})$, sulfate $\left(\mathrm{SO}_{4}\right)$, roron (B), nitrate $\left(\mathrm{NO}_{3}\right)$, nitrite $\left(\mathrm{NO}_{2}\right)$, ammonium $\left(\mathrm{NH}_{4}\right)$, and phosphate $\left(\mathrm{PO}_{4}\right)$. Minimum reporting levels for metals depends on the analytical method; reporting levels for $\mathrm{Ba}, \mathrm{Fe}$, and $\mathrm{Mn}$ are higher for analysis by atomic absorption spectrometry than for analysis by atomic emission spectrometry by use of inductively-coupled plasma.

Radiochemical analysis of ground water included the determination of Ra-226, Ra-228, and gross alpha- and beta-particle activities and $U$ concentrations by use of methods outlined by Thatcher and others (1977). Rn-222 was measured by liquid scintillation by use of methods outlined by Pritchard and Gesell (1977) at the University of Maine, ${ }^{2}$ Orono, Maine. Ra-226, Ra-228, and gro's alpha- and beta-particle activity and dissolved $U$ concentrations were determined by Teledyne Isotopes, ${ }^{2}$ Westfield, N.J., for phases one and two of the study and by U.S. Testing, ${ }^{2}$ Richland, Wash., for phase three. Several duplicate samples from phases two and three and 12 samples from well CH-3335 were analyzed by the PaDER Bureau of Laboratories; samples compared acceptably, with no laboratory showing bias. Ra-226 activity was determined by Rn-222 emanation. Ra-228 activity was determined by coprecipitation with barium sulfate and subsequent beta counting. Dissolved $U$ concentration was determined by laser fluorometry (Teledyne) or laser-induced phosphorimetry (U.S. Testing). Gross alpha- and beta-particle activity was determined by precipitation of solids on plar het and counting. Alpha standards were americium-241 for analyses by Teledyne Isotopes and result: are reported as pCi/L. Alpha standards were natural-uranium (U-nat) for analyses by U.S. Testing, and results are reported as $\mu \mathrm{g} / \mathrm{L}$ as $U$-nat. Eighteen samples also were analyzed for isotopic $\mathrm{U}$ (U-23? .

\footnotetext{
2 The use of names of private laboratories is for identification purposes only and does not constitute endorsement by the U.S. Geological Survey.
} 
U-235, and U-234) by U.S. Testing by use of alpha spectrometry. Lowest level of reporting (lower limit of detection) and margin of error for each radionuclide varied depending on laboratory and background radioactivity during counting. Generally, the magnitude of counting error increases witl the magnitude of the determined activity for radionuclides. Reported activity values should be interpreted with caution because of the uncertainty associated with measurement.

Borehole geophysical logging of domestic and monitoring wells penetrating the Chickies Quartzite was completed by the USGS. Geophysical logs included some or all of the following on each well: caliper, fluid-temperature, fluid-resistivity, electrical (single-point-resistance and spontaneouspotential), natural-gamma-ray, and fluid-velocity (brine-trace) logs. Logging probes and tools for gamma-ray and electrical logs were not calibrated, and logs are interpreted relative to each other. The gamma-ray-logging tool measures total gamma-ray radiation in a selected energy range and dons not differentiate among gamma-ray emitters. Usually, about 90 percent of the gamma radiation detected originates within 12 in. of the borehole, and higher energy radiation travels farther than lower energy radiation (Keys, 1989). Among natural gamma-ray emitters, gamma activities of the Th-232 and U-238 decay series are much greater than that of K-40 (Keys, 1989).

The Ra-226 and Ra-228 activities in six rock samples were determined by use of standard methods for dissolved Ra-226 and Ra-228 following total dissolution of the rock by PaDER Bureau of Laboratories. Rock samples and well cuttings were analyzed using neutron activation to determine total $U$ concentration by delayed neutron counting and Th content by instrumental activation analysis (INAA) by Nuclear Activation Services, Ann Arbor, Mich. Gamma-ray spectrometry of well cuttings and suspended solids collected by filtering ground-water samples were performed by Teledyne Isotopes. Gamma-ray spectrometry measures the gamma-ray activity of several high-energy gamma rays, including those of K-40 and some radionuclides in the U-238 and Th-232 decay series.

Heavy minerals were identified in collaboration with C. Gil Wizwall and David Sinson at West Chester University, West Chester, Pa., and by Linda C. Gunderson, USGS, in Reston, Va. Rock samples and well cuttings were crushed, sieved, and panned. Dense liquids (bromoform) were used to further separate the heavy minerals, and a Frantz magnetic separator at Bryn Mawr College was used to remove magnetite.

Nonparametric statistics were used in data analysis. Parametric statistics traditionally are used in the analysis of normally distributed data sets; however, hydrologic data, and water-quality data in particular, commonly are not normally distributed (Helsel, 1987, p. 180). Ra-226, Ra-228, and Rn-222 activity data are positively skewed. In addition, the data are bounded at the detection limit of the analytical method, and some concentrations are reported as less than the detection limit. Nonparametric statistics are powerful and robust when used to analyze nonnormally distributed data, such as badly skewed environmental data.

Multiple detection limits for radionuclides arise because of (1) variances in the background radioactivity during counting at time of the analysis, and (2) the use of two laboratories having different reporting levels. All data less than the maximum detection limit is set equal to that detection limit; nonparametric statistical tests assign the same rank to all concentrations that aro the same (Helsel, 1987, p. 189). The maximum detection limits for Ra-226 and Ra-228 activities are $0.1 \mathrm{pCi} / \mathrm{L}$ and $1.0 \mathrm{pCi} / \mathrm{L}$, respectively.

Differences in Ra-226, Ra-228, and Rn-222 activities in ground water in different lithologies were tested by use of the Kruskal-Wallis test, a nonparametric one-way analysis of variance (ANOVA). The Kruskal-Wallis null hypothesis is that a number of independent groups come from the same population or from populations with equal mean rank. The significance of the equality of the means of the ranks is tested against the chi-square distribution. For this study, the null hypothesis was rejected at a 95-percent confidence level. If the null hypothesis is rejected, the alternative hypothesis is that at least one group is from a different population. However, the test does not indicate which group is different. Further testing by use of a nonparametric multiple comparison test (MCT) must be performed to identify the group or groups that come from a separate population.

6 WATER-RESOURCES INVESTIGATIONS REPORT 92-4088 
A multiple comparison test (MCT) is a procedure to determine the relative ordering of population mean rank. This test was used only after the null hypothesis of the ANOVA was rejected. The MCT using the Kruskal-Wallis statistic recommended by Campbell and Skillings (1985) was used. The purpose of the MCT is to find differences in smaller subsets as long as test results are statistically significant; for this study, the null hypotheses of no differences was rejected at the overall 95-percent confidence level.

Spearman's rho correlation coefficient $\left(r_{s}\right)$ test was used to determine the specific chemical constituents and properties that correlated with $\mathrm{Ra}-226, \mathrm{Ra}-228$, and $\mathrm{Rn}-222$ in ground water. Spearman's rho is a nonparametric test to measure monotonic correlation between two variables. Monotonic correlations are not necessarily linear but arise when two parameters either change magnitude at any rate in the same or opposite directions. It is calculated by use of rank-transformed data. Positive correlation results when large values of the first variable are associated with large. values of the second variable. A negative correlation results when large values of the first variable are associated with small values of the second variable. All correlations discussed in this report have at least a 95-percent significance level (p-values less than 0.05).

Values of $r_{\mathrm{s}}$ should not be interpreted in the same manner as values for the equivalent parametric test, Pearson's product-moment correlation coefficient (r). If the relation between the two variables is curvilinear rather than linear, the value of $r_{s}$ will tend to be higher (closer to -1 or +1 ) than the value for $r$ (Iman and Conover, 1983, p. 127 and 340). Spearman's rho, unlike Pearson's product-moment correlation coefficient, is not sensitive to outliers in the data since ranks of the values are used instead of the actual values. It is an inappropriate procedure to square $\mathbf{r}_{\mathbf{s}}$ to determine the percent variability of y explained by $x$ (D.R. Helsel, U.S. Geological Survey, oral commun., 1989).

A positive or negative correlation between a chemical constituent and radionuclide activity may be used in two ways. A statistically significant correlation can be used to characterize the environment associated with elevated radionuclide activities. A significant, but low, $\mathbf{r}_{\mathrm{s}}$ indicates that a relation exists between the two parameters. This relation does not necessarily imply cause and effect; therefore, the correlations are evaluated in terms of possible geochemical reactions or phy:ical processes that may control the concentration and distribution of radionuclides and other chemical constituents that behave in a manner similar to the radionuclides. A statistically significant correlation between a chemical constituent can also be used to indicate the presence (positive correlation) or absence (negative correlation) of elevated radionuclide activity if the $r_{\mathrm{s}}$ is high and the plot of the two variables does not show much scatter. An $r_{s}=0.60$ is considered a strong correlation for the nonparametric Spearman's rho correlation (D.R. Helsel, U.S. Geological Survey, oral commun., 1989). 


\section{Previous Investigations}

The geology of the Chickies Quartzite was first described by Rogers (1858). The formation was later studied by Lesley and Frazer who differentiated it from other "primal quartzites" and named it Chickies Quartzite in 1878, on the basis of the type locality of Chickies Rock in Lancaster County (Knopf and Jonas, 1929). Bascom and others (1909), Bascom and Stose (1938), Knopf and Jonas (1929), Stose and Jonas (1939), Stose and Stose (1944), and Willard and others (1959) further describe the formation. A summary of the early work is given by Engelder (1976). More recent geologic investigations have been performed for senior and master's theses, covering topics such as structural relations with underlying crystalline rocks (Murphy, 1973), facies descriptions (Hyde, 1971), and friability and geochemistry (Engelder, 1976). Recent papers focusing on the Chickies Quartzite include discussions of tectonic implications (Adams and Goodwin, 1975), and sedimentary structures and environments of deposition (Goodwin and Anderson, 1974). Chemical analyses of Chickies Quartzite whole rock and minerals are given in Berkheiser (1985).

In addition to geologic description, Bascom and Stose (1938), Knopf and Jonas (1929), and Stose and Jonas (1939) included remarks about economic use and water resources in their reports. General economic, engineering, and hydrologic characteristics of the formation are given in McGlade and others (1972) and Wilshusen (1979).

Publications presenting data and preliminary results of this study include Cecil, Smith, and others (1987), Cecil (1989), and Cecil, Senior, and others (1991). A relation between elevated Ra and low $\mathrm{pH}$ was reported by Cecil and others (1987).

\section{Acknowledgments}

The cooperation of well owners for providing data and granting access to wells for water samples is gratefully acknowledged. Assistance in quality assurance and interpretation of $\mathrm{Ra}$ and $\mathrm{Rn}$ analyses of water samples was provided by Margaret Reilly of the PaDER Bureau of Radiation Protection, Michael Webb of the PaDER Bureau of Laboratories, and Charles T. Hess of the University of Maine, Orono. Donna Snyder of the Pennsylvania Bureau of Topographic and Geologic Survey (PAGS) provided driller's records of wells. The cooperation of geologists of Environmental Resources Management, Inc. and Jack Kelly of the USEPA for data is appreciated.

Valuable contributions to solid-phase investigations were made by Robert C. Smith, II, of the PAGS, C. Gil Wizwall and David Sinson of West Chester University, Michael Webb, PaDER, Bureau of Laboratories, and William Crawford and Robert Cook of Bryn Mawr College. 


\section{HYDROGEOLOGIC SETTING}

The Chickies Quartzite crops out in the Piedmont Physiographic Province of southeastern Pennsylvania. In the Piedmont, ground-water basins are relatively small and generally have boundaries or divides coincident with ridge tops. Ground water discharges to nearby perennial streams. Geologic formations are not flatlying, and water is present in fractures in bedrock and in the overlying weathered material. Flowpaths are short and are controlled, in part, by topography.

\section{Geology}

The Chickies Quartzite is the basal member of the Lebanon Valley sequence (Berg and others, 1986) and Chester and Conestoga Valley sequences (Lyttle and Epstein, 1987) of Paleozoic metasediments that crop out in the Piedmont Physiographic Province. The Chickies Quartzite-a basal metaconglomerate, quartzite, and slate-is Lower Cambrian in age and rests unconformably on deformed and metamorphosed Precambrian crystalline rocks. The Chickies Quartzite is one of sevaral Cambrian quartzose formations that rest unconformably on older crystalline rocks in the Piedmont. In Pennsylvania, the conglomerates are basal members of these quartzose formations and crop out in discontinuous east-northeast- or northeast-trending belts. To the north of the Chickies Quartzite in east-central Pennsylvania is the Hardyston Quartzite, a Cambrian-age basal conglomerate and quartzite formation that is associated with the Reading Prong of the New England Physiographic Province.

The Antietam Quartzite and Harpers Phyllite are Cambrian-age quartzite, quartz schist, and phyllite units that lie conformably above the Chickies Quartzite. In the eastern part of the study area, the Antietam Quartzite and Harpers Phyllite are missing or not recognized. In this region, the Cambrian-age Ledger Dolomite and Cambrian- and Ordovician-age Conestoga Limestone are mapred in depositional contact with the Chickies Quartzite. The Antietam Quartzite and Harpers Phyllite are mapped as one undifferentiated unit in most areas. A generalized section (fig. 2) for the central part, of the study area shows the stratigraphic relations.

The rocks of the Piedmont and Great Valley Physiographic Provinces have undergone sever 1 episodes of deformation and metamorphism, resulting in structurally complex assemblage of greenschist and greenschist-retrograde metamorphic rocks (Lyttle and Epstein, 1987). The Chickjes Quartzite in association with Precambrian crystalline rocks and overlying Paleozoic sediments has been mapped as part of large anticlinal and synclinal structures (Bascom and others, 1909; Stose and Stose, 1944). These structures have been further deformed and commonly are overturned and cut by faults. The Chickies Quartzite in some places is in fault contact with Precambrian basement and younger Paleozoic metasediments. Regional faults bound larger structures and generally trend northeast-southwest, with faults and folds commonly dipping to the southeast.

Composition of the underlying Precambrian crystalline basement rocks varies. Felsic gneiss is present in the eastern part of the study area; felsic and intermediate gneiss and mafic gneiss are present in the central part of the study area; and metavolcanic rocks, such as metarhyolite, are present in the western part of the study area. The variable composition of the basement could, in part, reflect the structural juxtaposition of different crystalline rock units prior to deposition of the Chickies Quartzite.

After deposition, the Chickies Quartzite was deformed and metamorphosed (up to greenschist facies). Some telescoping of basement units and associated cover rocks may have occurred, such t] at different slices of the Chickies Quartzite presently located near one another may have originally baen deposited far apart with different source areas for clasts. Sources for clasts were sedimentary, igneous, and metamorphic rocks and probably were located to the northwest of the Chickies Quartzite (Hyde, 1971).

Along the northern edge of the outcrop area, contacts between the Chickies Quartzite and overlying sedimentary units (Antietam Quartzite, Harpers Phyllite, Ledger Dolomite, or Conestogף Limestone) are covered in places by the Triassic Stockton Formation of the Newark Basin and the 


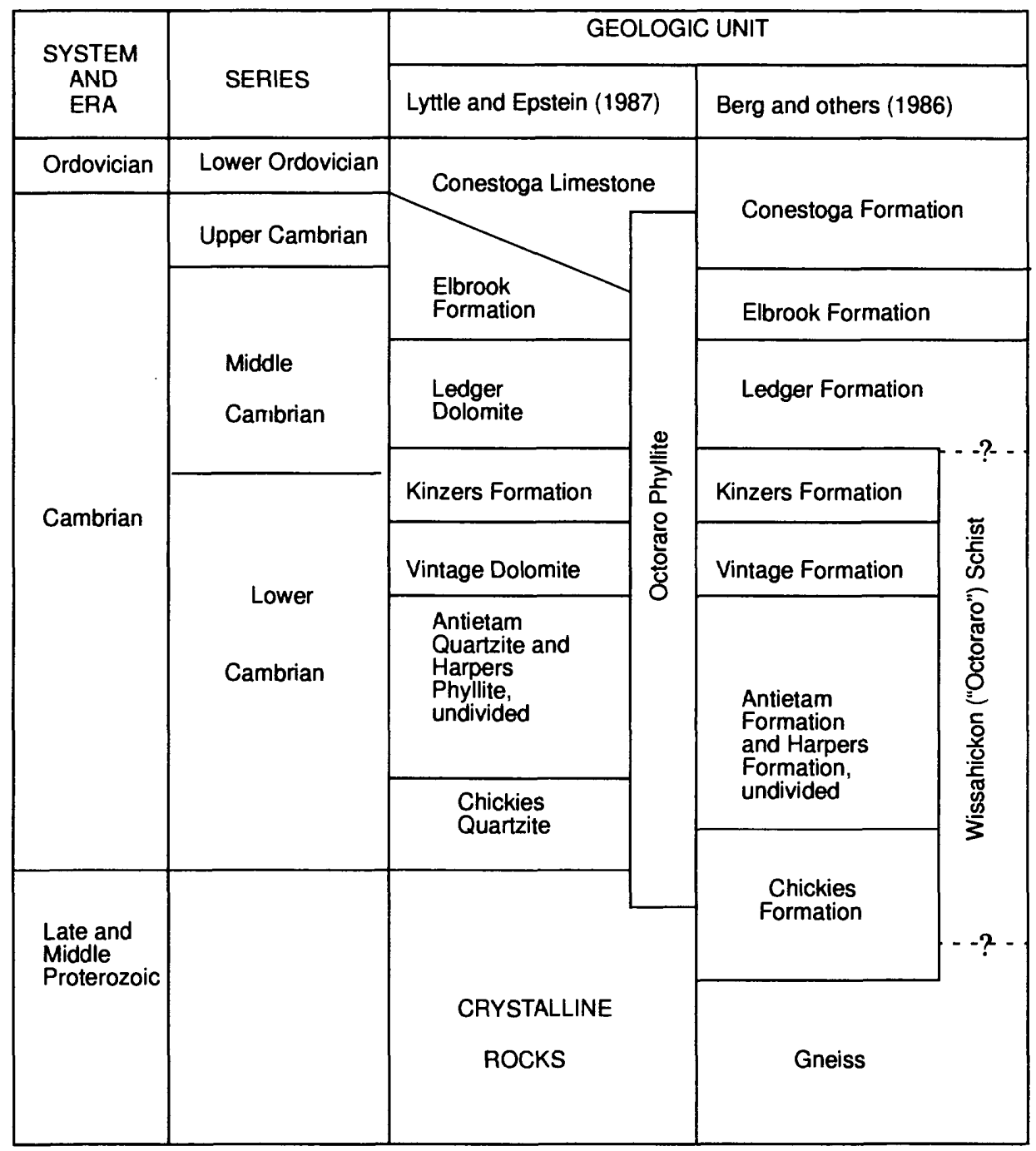

Figure 2. Generalized stratigraphy of lower Ordovician and older rocks in northcentral Chester County, Pennsylvania.

New Oxford Formation of the Gettysburg Basin. Lower Mesozoic diabase dikes intrude the Chickies Quartzite, cutting across contacts with underlying and overlying rocks.

The Chickies Quartzite is comprised of three lithologies-conglomerate, quartzite, and slatethat previously have been mapped as three members of the formation, the lower Hellam Membor and the upper Chickies Quartzite and Chickies Slate Members (Bascom and Stose, 1938; Stose and Stose, 1944). The PAGS uses the names of these members and the term Chickies Formation to refer to the separate lithologies and the entire formation, respectively (Berg and others, 1986; Wilshusen, 1979). This report uses the nomenclature of the USGS, Chickies Quartzite, to describe the entire form ation. The type locality of the Chickies Quartzite is an exposure of quartzite and slate named Chickies Rock on the east bank of the Susquehanna River in Lancaster County. The Chickies slate lithology has been mapped separately only in York County (Stose and Stose, 1944), and both other lithologies have been mapped in all counties where the formation occurs. Hyde (1971) recognized six facies with in the 
formation: conglomerates, cross-stratified quartz arenites, burrowed quartz arenites, feldspathic. wackes and arenites, quartz wackes, and mudstone. Thickness of the Chickies Quartzite is reported to range from 430 to 1,300 $\mathrm{ft}$ (Lyttle and Epstein, 1987). The environments of deposition have been interpreted as braided streams and intertidal and subtidal zones along a coastal margin (Hyde, 1971; Adams and Goodwin, 1975; Goodwin and Anderson, 1974).

The basal part of the Chickies Quartzite ("Hellam Member") is a coarse feldspar- and quart"pebble conglomerate grading into conglomeratic quartzite, with a quartz and sericitic matrix and accessory zircon, magnetite, and hematite (Bascom and Stose, 1938; Knopf and Jonas, 1929), rutile (G.C. Wizwall, West Chester University, oral commun., 1989), monazite, titanite and apatite (L.C. Gunderson, U.S. Geological Survey, oral commun., 1989). The conglomerate commonly consists of blue quartz pebbles in a pale green matrix. Interbeds of slate are reported by Stose and Stose (1914). Tourmaline crystals formed in-situ are found in the central and eastern areas of exposure of the conglomerate. Thickness of the conglomerate ranges from 200 to $500 \mathrm{ft}$ (Bascom and Stose, 1938; Stose and Jonas, 1939). The conglomerate is most prominent in York County, where it forms the Hellam Hills east of York; here are the coarsest conglomerate beds of the entire exposed formation. Sources of clasts in the conglomerate may have included the Precambrian crystalline rocks that currently are exposed and differ in composition from east (mafic gneiss and felsic gneiss) to west (metabasalt and metarhyolite).

Above the conglomerate, the Chickies Quartzite is a light-gray to white, vitreous to granular, massive to thin-bedded quartzite and sericitic quartz schist (Bascom and Stose, 1938). Thickness of the quartzite lithology ranges from 200 to $800 \mathrm{ft}$. In general, the quartzite is very "clean" but may contain small amounts of feldspar and accessory zircon, rutile, apatite, monazite, limonite after pyrite, hematite, magnetite, and unidentified opaque minerals. The sericitic quartz schist is pale gray to pale green. Murphy (1973) identified the pale-green mica as the phengite variety of muscovite. The quartzite and quartz schist has undergone recrystallization and commonly contains tourmaline (often stretched) and mica, especially in the central and eastern areas. Thin discontinuous beds of kaolinite in the quartzite have been interpreted as weathered mica- or feldpar-rich layers (Bascom and Stose, 1938). Quartz veins are present between and within beds. Hyde (1971) divided the quartzite lithology into four facies: (1) argillaceous quartzite and (2) quartz wacke dominant in the eastern area; (3) cross-bedded and burrowed quartz arenites in the east-central, north-central, and western areas; and (4) feldspathic wackes in the south-central area.

Some of the compositional differences between the facies of the quartzite are shown by rocksample analyses. In the eastern part of the study area, sericitic quartzite from Bucks and Montgomery Counties is reported to contain up to 22 percent $\mathrm{Al}_{2} \mathrm{O}_{3}$ and 12.6 percent $\mathrm{K}_{2} \mathrm{O}$ (table 1 ). In the east-central and north-central areas in Chester and Lancaster Counties, the quartzite is a relatively clean quartzite, and some samples are 99 percent or more $\mathrm{SiO}_{2}$ (Berkheiser, 1985). Bulk chemistry of the quartzite in western Lancaster County was determined by Engelder (1976) from 26 samples (table 1). The Fe content of the quartzite increases to the west from Lancaster County (Berkheiser, 1985). Large pyrite crystals are common in the quartzite in York County.

Engelder (1976) determined that the quartzite contains more $\mathrm{K}$ and titanium (Ti) and less $\mathrm{Si}$, $\mathrm{Ca}$, and $\mathrm{Na}$ than an average quartzite or an average arkose; more $\mathrm{Al}$ and $\mathrm{Mn}$ than an average orthoquartzite; but less $\mathrm{Al}, \mathrm{Fe}, \mathrm{Mg}$, and $\mathrm{Mn}$ than an average arkose. The samples of quartzite from Bucks and Montgomery Counties (table 1 ) also contain less $\mathrm{Ca}$ and more $\mathrm{Ti}$ and $\mathrm{K}$ than the averare arkose or orthoquartzite (Pettijohn, 1963). In an analysis of texture, mineralogy, and composition. quartz correlated negatively with feldspar, mica, and matrix associated with $\mathrm{K}, \mathrm{Fe}, \mathrm{Mg}$, and $\mathrm{Ti}$ (Engelder, 1976). 
Table 1. Average bulk composition of 26 rock samples of the Chickies Quartzite, Lancaster County, 1 rock sample from the type locality, and 3 rock samples from Bucks and Montgomery Counties

[In percent; --, no data]

\begin{tabular}{lccccc}
\hline \multicolumn{1}{c}{ Constituent } & $\begin{array}{c}\text { Lancaster } \\
\text { County }\end{array}$ & $\begin{array}{c}\text { Bucks } \\
\text { County }\end{array}$ & $\begin{array}{c}\text { Bucks } \\
\text { County }\end{array}$ & $\begin{array}{c}\text { Montgomery } \\
\text { County }\end{array}$ & $\begin{array}{c}\text { Type } \\
\text { locality }\end{array}$ \\
\hline $\mathrm{SiO}_{2}$ & 93.17 & 87.87 & 58.97 & 56.35 & 97.10 \\
$\mathrm{Al}_{2} \mathrm{O}_{3}$ & 2.88 & 6.61 & 22.61 & 22.28 & 1.39 \\
$\mathrm{Fe}_{2} \mathrm{O}_{3}$ & 4.62 & 2.39 & 5.67 & 3.21 & 1.25 \\
$\mathrm{MgO}$ & .14 & Trace & .25 & 1.40 & .13 \\
$\mathrm{MnO}$ & .06 & .13 & - & Trace & -- \\
$\mathrm{CaO}$ & .02 & .24 & .08 & .19 & .18 \\
$\mathrm{TiO}$ & .42 & .38 & 1.11 & .82 & -- \\
$\mathrm{Na}_{2} \mathrm{O}$ & .02 & .19 & .32 & .38 & - \\
$\mathrm{K}_{2} \mathrm{O}$ & 1.24 & 1.73 & 7.34 & 12.63 & - \\
$\mathrm{Na}_{2} \mathrm{O} / \mathrm{K}_{2} \mathrm{O}$ & .01 & .11 & .04 & .03 & -- \\
\hline
\end{tabular}

1 From Engelder (1976).

2 From Bascom and others (1909).

3 Chickies Rock, Lancaster County, from Jonas and Stose (1930).

4 Given as total Fe.

Engelder (1976) interpreted the quartzite in western Lancaster County to be arkosic and a near-source deposit of sediment based on chemical analyses and mineral distributions. Goodwin and Anderson (1974) described the environment of deposition of the quartzite as a mosaic of subtidal channels, intertidal flats, and tidal flat ponds based on identifiable physical and biogenic structures, such as stratification, bed form, grain size, and fossil burrow forms. The variable composition of the quartzite is a result of the environment of deposition (Berkheiser, 1985) as well as possible differences in source material.

The Chickies slate lithology lies above the conglomerate and is probably stratigraphically equivalent to the quartzite. It is mapped as a separate unit (Stose and Jonas, 1939) south of the Hanover-York carbonate valley in York County. The slate lithology consists of interbedded slate, phyllite, and quartzite and contains quartz, albite, chlorite, muscovite, magnetite, zircon, and tourmaline (Stose and Stose, 1944). Slate and quartzite have been mapped separately within the Chickies slate unit (Stose and Stose, 1944). The Chickies slate unit corresponds to the mudstore facies of Hyde (1971) that was deposited in a subtidal shelf. 


\section{Ground-Water System}

The Chickies Quartzite is a water-table aquifer recharged directly by precipitation. Geners.lly, soil cover is thin ( 1 to $5 \mathrm{ft}$ ), and depth to competent bedrock commonly is $10 \mathrm{ft}$ or less. Openings to the surface and within the aquifer have developed along a complex interconnected network of beddiro, joints, and structurally controlled planes, such as cleavage, faults, and fractures.

Generally, the water table is a subdued replica of the topography, and ground-water divide.coincide with ridge tops. Median depth to water was $69 \mathrm{ft}$ in wells on hilltops (31 measurements ranged from 29 to $105 \mathrm{ft}$ ) and $50 \mathrm{ft}$ in wells on slopes (67 measurements ranged from 1.3 to $130 \mathrm{f}$ ). Springs on slopes are indicative of a shallow water table and (or) a local flow system. Because th: Chickies Quartzite is resistant to erosion, it forms ridges and is topographically higher than adjacent geologic units; therefore, ground water from the Chickies discharges to the surface or to adjacent geologic units. Ground water flows from the quartzite, which commonly underlies ridge crests, through the conglomerate that underlies slopes, and toward the contact with underlying Precamk rian crystalline rocks to one side of the ridge. On the other side of the ridge, ground water flows from the quartzite through the Antietam Quartzite and Harpers Phyllite, which underlie slopes, and toward the contact with overlying carbonates. The strike of the Chickies Quartzite is roughly parallel to the ridge line. Ground-water divides commonly coincide with ridge crests, and, thus, geologic, topographic, and hydrologic conditions coincide to create a situation where the maximum horizontal hydraulic gradient is approximately perpendicular to strike.

Ground-water flow in the Chickies Quartzite is driven by the hydraulic gradient through a network of fractures. Each fracture opening penetrated by a well may have a different hydraulic head, and ground water flows from higher to lower head. The existence of a vertical hydraulic gradient between openings is shown by the downward movement of a tracer observed in the geophysical log of a ridge-top well (CH-3315). Water-level data and geophysical logs from four pairs of deep and shallow monitoring wells drilled for the investigation of William Dick Lagoons Nationel Priorities List (Superfund) site suggest that vertical gradients (down) are greatest near the ridg!? crest and decline to almost zero near mid-slope areas of discharge.

Analysis of frequency of water-bearing zones in the Chickies Quartzite shows most zones \& re within $150 \mathrm{ft}$ of land surface (table 2). Frequency of water-bearing zones decreases with depth, ard no zones are reported at depths greater than $400 \mathrm{ft}$ below land surface, although data are limited b:low $400 \mathrm{ft}$. This analysis supports the model of a shallow, local flow system in the Chickies Quartzite. similar to other geologic units in the Piedmont (Trainer, 1988). The data do not preclude groundwater flow at depths greater than $400 \mathrm{ft}$.

Table 2. Number of water-bearing zones per 100 feet of uncased borehole for 151 wells drilled in the Chickies Quartzite

\begin{tabular}{lccc}
\hline $\begin{array}{c}\text { Interval of depth } \\
\text { below land surface } \\
\text { (in feet) }\end{array}$ & $\begin{array}{c}\text { Number of water- } \\
\text { bearing zones }\end{array}$ & $\begin{array}{c}\text { Footage of open } \\
\text { hole sampled }\end{array}$ & $\begin{array}{c}\text { Water-bearing } \\
\text { zones per } \\
\text { foot } \times 100\end{array}$ \\
\hline $0-50$ & 32 & 808 & 3.96 \\
$51-100$ & 103 & 4,134 & 2.49 \\
$101-150$ & 82 & 4,887 & 1.68 \\
$151-200$ & 43 & 3,189 & 1.35 \\
$201-250$ & 22 & 2,046 & 1.08 \\
$251-300$ & 17 & 1,117 & 1.52 \\
$301-350$ & 3 & 374 & .80 \\
$351-400$ & 2 & 150 & 1.33 \\
Below 400 & 0 & 57 & 0 \\
Total & 304 & 16,762 & 1.81 \\
\hline Most data are from driller reports. Some data are from geophysical log \\
interpretations.
\end{tabular}




\section{Well-Construction Characteristics}

Wells in the Chickies Quartzite are drilled by air hammer, air-rotary, or cable-tool methods. Wells are commonly 6 in. in diameter, although nondomestic wells may be larger. Steel or plastic casing is set into competent rock, and the interval below the casing is left as an open hole. Water enters the well from one or more water-bearing zones intercepted by the uncased section of the well. Submersible pumps commonly are set about $20 \mathrm{ft}$ above the bottom of the hole.

The range and median of well depth and casing length for wells completed in the Chickies Quartzite and sampled for this study are given in table 3. Median depth and casing length for wells in the Chickies Quartzite are similar to those for other minor aquifers in Chester County (Poth, 1968) and York County (Wilshusen, 1979). Wells on hilltops tend to be deeper and require less casing t $\mathrm{t}$ ?n wells on slopes or at the base of slopes. In the Chickies Quartzite, the median well depth is slightly greater for wells drilled on hilltops than slopes; the median casing length is slightly less for wells drilled on hilltops than slopes (table 3).

Table 3. Range and median of depth and casing length of wells drilled in the Chickies Quartzite [Min, minimum; Max, maximum]

\begin{tabular}{lrrrr}
\hline \multirow{2}{*}{ Well characteristics } & Number of wells & \multicolumn{2}{c}{ Range } & \multirow{2}{*}{ Median } \\
\cline { 3 - 4 } Well depth (feet) & & Min & Max & \\
All wells & 137 & & & 162 \\
Hilltop & 50 & 70 & 500 & 169 \\
Slope & 87 & 40 & 500 & 160 \\
Conglomerate & 51 & 63 & 407 & 150 \\
Quartzite & 79 & 40 & 500 & 175 \\
Slate & 7 & 100 & 407 & 160 \\
Casing length (feet) & & & 300 & \\
All wells & 120 & 13 & & 47 \\
Hilltop & 40 & 20 & 168 & 43 \\
Slope & 80 & 13 & 168 & 47 \\
Conglomerate & 45 & 13 & 145 & 43 \\
Quartzite & 70 & 20 & 125 & 52 \\
Slate & 5 & 30 & 168 & 40 \\
\hline
\end{tabular}

The median well depth and casing length is greater for wells drilled in the quartzite than the conglomerate or the slate (table 3). The quartzite commonly underlies hilltops, although at depth, the quartzite may weather to a loose quartz sand. In Chester County, well owners in some areas repcrt continual pumping of fine sand. 


\section{Well Yield and Specific Capacity}

Reported yield and specific capacity are indicators of aquifer productivity and hydraulic conductivity (permeability). Nondomestic wells commonly are drilled and constructed for the largest yield obtainable. Specific capacity is the measure of well yield per foot of drawdown of water leve' in a well. The range and median yield and specific capacity for 116 domestic and 4 nondomestic wells completed in the Chickies Quartzite and sampled for this study are given in table 4. Specific capacities are less than 1.0 ( $\mathrm{gal} / \mathrm{min}) / \mathrm{ft}$ for more than 80 percent of the wells. Median specific capacity and yield of wells completed in the Chickies Quartzite are less than those reported for most major and some minor aquifers in Chester County (Poth, 1968) and York County (Wilshusen, 1979). Few public supply wells are completed in the Chickies Quartzite.

Table 4. Range and median of reported yield and specific capacity of wells drilled in the Chickies Quartzite

[Min, minimum; Max, maximum; <, less than; --, no data]

\begin{tabular}{lcccc}
\hline \multirow{2}{*}{ Well characteristic } & Number of wells & \multicolumn{2}{c}{ Range } & \multirow{2}{*}{ Median } \\
\cline { 2 - 3 } & & Min & Max & \\
\hline Reported yield (gallons per minute) & & & 10 \\
All wells & 120 & 0.5 & 100 & 8 \\
Hilltop & 41 & 1 & 40 & 10 \\
Slope & 79 & .5 & 100 & 11 \\
Conglomerate & 43 & .5 & 100 & 7.8 \\
Quartzite & 72 & .5 & 96 & 10 \\
Slate & 5 & 4 & 20 & \\
Specific capacity (gallons per minute per foot of drawdown) & & .14 \\
All wells & 48 & $<.01$ & 15 & .14 \\
Hilltop & 15 & .02 & 15 & .15 \\
Slope & 33 & $<.01$ & 2.5 & .34 \\
Conglomerate & 13 & .02 & 1.7 & .13 \\
Quartzite & 35 & $<.01$ & 15 &.- \\
Slate &.- & -- & - & \\
\hline
\end{tabular}

Differences in well yield and specific capacity related to topography and lithology appear to be small for the Chickies Quartzite. The range and median yield and specific capacity for wells drilled on hilltops and slopes in different lithologies of the Chickies Quartzite are given in table 4. The metian yield and specific capacity are slightly greater for wells drilled on slopes than on hilltops. Rocks underlying slopes erode more easily and may be more permeable than rocks underlying hilltops. The median yield and specific capacity is greater for wells completed in conglomerate, which commonly underlies slopes, thain in quartzite, which commonly underlies hilltops. Median yield for wells completed in the slate (underlying slope and hilltop) is slightly less than that for the conglomerrte. 


\section{Ground-Water Quality}

The chemical composition of ground water in a water-table aquifer is determined by the chemical composition of recharge and the subsequent chemical reactions along the flow path thrcigh the soil zone and aquifer. Many chemical reactions and processes are associated with mineral weathering, including dissolution and precipitation of minerals, oxidation-reduction, ion-exchang ${ }^{\circ}$, and adsorption. Some reactions may be biologically mediated. Recharge water can acquire additional $\mathrm{NO}_{3}$ and salts from anthropogenic sources such as fertilizer, road salt, and septic-system dischar $: e$.

The Chickies Quartzite is recharged primarily by acidic precipitation. In 1979-80, 22 samples of precipitation were collected in central Chester County for chemical analysis. Median total concentrations measured were $0.2 \mathrm{mg} / \mathrm{L} \mathrm{Na}, 0.1 \mathrm{mg} / \mathrm{L} \mathrm{K}, 0.6 \mathrm{mg} / \mathrm{L} \mathrm{Ca}, 0.15 \mathrm{mg} / \mathrm{L} \mathrm{Mg}, 0.4 \mathrm{mg} / \mathrm{L} \mathrm{Cl}$. $0.6 \mathrm{mg} / \mathrm{L} \mathrm{NO}_{3}$ as $\mathrm{N}, 4.3 \mathrm{mg} / \mathrm{L} \mathrm{SO}_{4}$, and $1.5 \mathrm{mg} / \mathrm{L} \mathrm{DOC}$; the median $\mathrm{pH}$ was 4.1 . Maximum concentrations were $1.2 \mathrm{mg} / \mathrm{L}$ for $\mathrm{Na}, 5.8 \mathrm{mg} / \mathrm{L}$ for $\mathrm{Ca}, 19 \mathrm{mg} / \mathrm{L}$ for $\mathrm{Mg}, 2.9 \mathrm{mg} / \mathrm{L}$ for $\mathrm{Cl}$, and $10 \mathrm{mg} / \mathrm{L}$ for $\mathrm{SO}_{4}$; $\mathrm{pH}$ was as low as 3.6.

The Chickies Quartzite is composed mostly of quartz, which is a source of dissolved $\mathrm{SiO}_{2}$; however, quartz has a low solubility in the $\mathrm{pH}$ range of most natural waters. Some silicate miner $\mathrm{als}$, such as mica and feldspar, are soluble in the $\mathrm{pH}$ range of the ground water. Silicate-mineral weathering results in an increase in $\mathrm{pH}$, alkalinity, and concentrations of $\mathrm{SiO}_{2}, \mathrm{Ca}, \mathrm{Mg}, \mathrm{K}$, and $\mathrm{Na}$ in ground water. Silicate-mineral sources include microcline for $\mathrm{K}$; plagioclase for $\mathrm{Ca}$; micas (biotite, sericite, phengite) for $\mathrm{K}, \mathrm{Mg}$, and $\mathrm{Fe}$; and tourmaline for $\mathrm{B}$. Ba and other trace elements may be present as replacement ions in or be adsorbed by silicates, by Mn-oxides or Fe-oxides, or by other minerals in the Chickies Quartzite. The weathering of pyrite involves the oxidation of sulfur and results in a decrease in $\mathrm{pH}$ and an increase in $\mathrm{SO}_{4}$ concentration in ground water; Fe released may be precipitated as an iron oxide.

The ground water of the Chickies Quartzite is generally acidic, soft (less than $60 \mathrm{mg} / \mathrm{L} \mathrm{Ca} \mathrm{F}^{1} \mathrm{us}$ $\mathrm{Mg}$ ), and low in total dissolved solids (TDS) and alkalinity. Table 5 lists the range and median of analyzed chemical constituents and measured chemical properties for well-water samples. Acidic recharge water, low solubility of quartz, sparsity of easily dissolved $\mathrm{Ca}$ - and $\mathrm{Mg}$-bearing minerals in the aquifer, and the small amount of mineral weathering because of a short residence time of ground water can account for the soft, acidic, and dilute character of the ground water.

The median concentrations of major ions in ground water of the Chickies Quartzite are up to 20 times greater than the median concentrations of those ions measured in precipitation in centr?l Chester County. The ground water acquires these ions from sources other than precipitation. Beca use median concentrations of $\mathrm{Na}, \mathrm{Cl}$, and $\mathrm{Mg}$ in ground water are up to 20 times as great as those in precipitation and $\mathrm{Na}, \mathrm{Cl}$, and $\mathrm{Mg}$ are not known to be abundant in the aquifer materials (table 1), enrichment of salts in ground water from septic systems or road salt is likely. The maximum concentrations of $\mathrm{Na}(59 \mathrm{mg} / \mathrm{L}), \mathrm{Cl}(100 \mathrm{mg} / \mathrm{L})$, and $\mathrm{NO}_{3}(16 \mathrm{mg} / \mathrm{L}$ in ground water) (table 5) probably are from wells affected by septic systems, road salt, and (or) fertilizers.

The median DOC concentration of $0.8 \mathrm{mg} / \mathrm{L}$ (table 5) is similar to the median DOC concentration of $0.7 \mathrm{mg} / \mathrm{L}$ in ground water for aquifers in the United States (Leenheer and others, 1974), but less than the median DOC concentration of $1.5 \mathrm{mg} / \mathrm{L}$ measured in precipitation in Chester Count.r. The specific organic compounds contributing to naturally occurring DOC is not known, although fulvic and humic acids are the most abundant naturally occurring compounds in ground water (Thurman, 1985). Naturally elevated DOC concentrations may indicate short residence time or ra pid infiltration of organic-rich recharge waters. Concentrations above $5 \mathrm{mg} / \mathrm{L}$ are uncommon and may indicate unnatural sources of DOC (Leenheer and others, 1974). The sample that contains $10 \mathrm{mg} / \mathrm{L}$ DOC is from a well (CH-3113) contaminated by benzene and other manufactured organic compounds.

Ground water in the Chickies Quartzite generally is well oxygenated; the median DO concentration is $7.6 \mathrm{mg} / \mathrm{L}$. DO at detectable concentrations (greater than $0.1 \mathrm{mg} / \mathrm{L}$ ) is associated with recharge areas having sandy or gravelly soils and shallow ground water or areas having little or no soil overlying permeable fractured rock (Freeze and Cherry, 1979). Dissolved oxygen concentrations similar to those in surface water may persist far into the flow system if ground water does not re $\varepsilon$, 
Table 5. Range and median concentrations of selected chemical constituents and properties for 160 wellwater samples from the Chickies Quartzite

[ $\mathrm{mg} / \mathrm{L}$, milligrams per liter; $\mu \mathrm{g} / \mathrm{L}$, micrograms per liter; $\mu \mathrm{S} / \mathrm{cm}$, microsiemens per centimeter at $25 \mathrm{~d}$ ?arees Celsius; ${ }^{\circ} \mathrm{C}$, degrees Celsius; <, less than]

\begin{tabular}{|c|c|c|c|c|}
\hline $\begin{array}{l}\text { Constituent } \\
\text { or property }\end{array}$ & $\begin{array}{c}\text { Number of } \\
\text { samples }\end{array}$ & \multicolumn{2}{|r|}{ Range } & Median \\
\hline \multicolumn{5}{|l|}{ Dissolved chemical constituents } \\
\hline $\mathrm{Ca}(\mathrm{mg} / \mathrm{L})$ & 159 & $<0.1-$ & 33 & 3.4 \\
\hline $\mathbf{M g}(\mathbf{m g} / \mathrm{L})$ & 159 & .2 & 14 & 2.9 \\
\hline $\mathrm{Na}(\mathrm{mg} / \mathrm{L})$ & 159 & .7 & 59 & 4.0 \\
\hline $\mathrm{K}(\mathrm{mg} / \mathrm{L})$ & 159 & 3 & 11 & 1.8 \\
\hline $\mathrm{Ba}(\mu \mathrm{g} / \mathrm{L})$ & 159 & $<2 \quad$ & 380 & 63 \\
\hline B $(\mu \mathrm{g} / \mathrm{L})$ & 58 & $<10$ & 290 & $<10$ \\
\hline $\mathrm{Fe}(\mu \mathrm{g} / \mathrm{L})$ & 159 & $<3$ & - $\quad 27,000$ & 20 \\
\hline $\operatorname{Mn}(\mu g / L)$ & 159 & $<1$. & 870 & 36 \\
\hline $\mathrm{Cl}(\mathrm{mg} / \mathrm{L})$ & 160 & 3 & 100 & 7.3 \\
\hline $\mathrm{SO}_{4}(\mathrm{mg} / \mathrm{L})$ & 160 & $<.2$ & 62 & 5.7 \\
\hline$F(m g / L)$ & 160 & $<.1-$ & .5 & $<.1$ \\
\hline $\mathrm{SiO}_{2}(\mathrm{mg} / \mathrm{L})$ & 160 & 3.4 & 28 & 8.3 \\
\hline $\mathrm{NO}_{3}(\mathrm{mg} / \mathrm{L}$ as $\mathrm{N})$ & 57 & $<.1$ & 16 & 1.1 \\
\hline $\mathrm{NH}_{4}(\mathrm{mg} / \mathrm{L}$ as $\mathrm{N})$ & 57 & $<.01$ & 1.4 & $<.01$ \\
\hline $\mathrm{PO}_{4}(\mathrm{mg} / \mathrm{L}$ as $\mathrm{P})$ & 58 & $<.001$ & .052 & $<.001$ \\
\hline $\mathrm{DOC}(\mathrm{mg} / \mathrm{L})$ & 147 & .30 & 10 & .80 \\
\hline \multicolumn{5}{|l|}{ Total chemical constituent } \\
\hline $\mathrm{Fe}(\mu \mathrm{g} / \mathrm{L})$ & 159 & $<10$ & 44,000 & 180 \\
\hline Total dissolved solids (mg/L) & 159 & 7 & 299 & 51 \\
\hline \multicolumn{5}{|c|}{ Chemical and physical properties measured in the field } \\
\hline pH units & 160 & 4.3 . & 6.9 & 5.1 \\
\hline Alkalinity $\left(\mathrm{mg} / \mathrm{L}\right.$ as $\left.\mathrm{CaCO}_{3}\right)$ & 156 & $<1 \quad-$ & 130 & 6.0 \\
\hline Specific conductance $(\mu \mathrm{S} / \mathrm{cm})$ & 160 & 10 & 633 & 85 \\
\hline Dissolved oxygen (mg/L) & 154 & $<.1-$ & 12.1 & 7.6 \\
\hline Temperature $\left({ }^{\circ} \mathrm{C}\right)$ & 159 & 9.0 & 16.0 & 12.0 \\
\hline
\end{tabular}

with oxidizable species, the most important being organic materials and reduced inorganic minerals, such as pyrite and siderite (Hem, 1986). The oxidation of pyrite, a mineral in the Chickies Quartzite, would be favored in the acidic and oxygen-rich ground water.

Dissolved and total iron concentrations greater than $1 \mathrm{mg} / \mathrm{L}$ were measured in water from wells in all areas. Concentrations of dissolved $\mathrm{Mn}$ and Fe exceed USEPA secondary maximum contaminant level (SMCL) standards for these constituents $(50 \mu \mathrm{g} / \mathrm{L}$ and $300 \mu \mathrm{g} / \mathrm{L}$, respectively) in 35 percent of the samples analyzed for $\mathrm{Mn}$ and 15 percent of the samples analyzed for $\mathrm{Fe}$. Over the observed $\mathrm{pH}$ range, bivalent (reduced) Fe and Mn cations probably are stable in solution. Field determination of ferrous and total Fe at a few sites by use of a spectro-photometric method (American Public Health Association and others, 1975) showed that the ferrous form predominates, consistent with low-pH conditions. 
The range of compositions shown on piper diagrams (figs. 3 and 4) indicates that the ground water in Chickies Quartzite does not have narrowly defined chemical character in terms of relative ion concentrations, although some differences in chemical character in different geographic areas and lithologies are indicated. Samples that have a cation-anion balance (difference less than 10 percent) are plotted on piper diagrams (figs. 3 and 4). In dilute waters, small differences or errors in ion concentrations have a large relative effect on composition. The sum of major cations for all samples ranges from 0.1 to $7.0 \mathrm{meq} / \mathrm{L}$, with a median of $0.9 \mathrm{meq} / \mathrm{L}$.

$\mathrm{Na}$ and $\mathrm{K}$ are the dominant cations in some ground-water samples, especially those from the central area and from the quartzite and conglomerate lithologies. In other water samples, especially those from the eastern and western areas and from the slate lithology, $\mathrm{Ca}$ and $\mathrm{Mg}$ are the dominant cations and $\mathrm{HCO}_{3}$, and $\mathrm{Cl}$ (plus $\mathrm{NO}_{3}$, when available) are the dominant anions. In a few water samples, mostly from the quartzite and conglomerate lithologies in the central area, $\mathrm{SO}_{4}$ is the dominant anion. Ground water in the slate is less acidic (median $\mathrm{pH}$ is 6.4) than ground water in the conglomerate, quartzite, or slate quartzite (median $\mathrm{pH}$ of 5.0,5.2, and 5.7, respectively).

Associations between major ions vary. The nonparametric Spearman rho correlation test performed on chemical constituents identified some statistically significant correlations at the 95-percent confidence interval (table 6). Na most strongly correlates with $\mathrm{Cl}$ and is associated to a successively lesser degree with $\mathrm{NO}_{3}$ and other major ions. $\mathrm{K}$ most strongly correlates with $\mathrm{NO}_{3}$ and less strongly with $\mathrm{Cl}$ and other major ions. $\mathrm{Ca}$ and $\mathrm{Mg}$ most strongly correlate with each other ard with $\mathrm{NO}_{3}, \mathrm{Cl}, \mathrm{Na}$, and $\mathrm{SO}_{4}$, but less strongly with $\mathrm{K}, \mathrm{SiO}_{2}$, and alkalinity $\left(\mathrm{HCO}_{3}\right)$. Increases in all major cations are accompanied by increases in specific conductance. Relatively high $\mathrm{pH}$ correlates with high alkalinity and high $\mathrm{SiO}_{2}$ and $\mathrm{Ca}$ concentrations and low $\mathrm{K}, \mathrm{Cl}$, and $\mathrm{SO}_{4}$ concentrations Relatively high DO concentrations correlate with low $\mathrm{pH}$ and alkalinity and low concentrations of all ions. Relatively high DOC concentrations correlate with low $\mathrm{pH}$, high concentrations of most major ions, but low alkalinity and low $\mathrm{SiO}_{2}$ concentrations.

$\mathrm{Ba}$ is similar to $\mathrm{Ca}$ in correlation with other ions except that relatively high concentrations of $\mathrm{Ba}$, unlike $\mathrm{Ca}$, correlate with low $\mathrm{pH}$ and alkalinity and low concentrations of $\mathrm{SiO}_{2}$. Relatively high concentrations of $\mathrm{Mn}$ correlate with low $\mathrm{pH}$ and alkalinity, low concentrations of $\mathrm{DO}$ and $\mathrm{SiO}_{2}$, and high concentrations of $\mathrm{DOC}, \mathrm{Ba}$, and most major ions. Although $\mathrm{Fe}$ (total and dissolved) also negatively correlates with $\mathrm{DO}, \mathrm{Fe}$, unlike $\mathrm{Mn}$, only positively correlates with $\mathrm{pH}$ and alkalinity. The correlations for $\mathrm{Mn}$ and Fe suggest that these metals are present in reıatively greater concentrat:ons in reducing water (relatively low DO concentrations) but differ in their relation to other chemical constituents and $\mathrm{pH}$. The correlations for $\mathrm{NH}_{4}, \mathrm{PO}_{4}$, and $\mathrm{B}$ are based on small numbers of samples having concentrations greater than the reporting level and may not indicate important ion associations; concentrations greater than reporting level were measured in 29 of 57 water samples for $\mathrm{NH}_{4}$, in 21 of 58 samples for $\mathrm{PO}_{4}$, and in 10 of 58 samples for $\mathrm{B}$. $\mathrm{NH}_{4}$ only correlates with $\mathrm{K}$, and the positive correlation could reflect similar chemical properties as monovalent cations. Relatively high concentrations of $\mathrm{PO}_{4}$ correlate with high $\mathrm{pH}$ and concentrations of $\mathrm{SiO}_{2}$, and low concentrations of $\mathrm{SO}_{4}, \mathrm{Ba}, \mathrm{Fe}$ (total and dissolved), $\mathrm{Mn}$, and DOC. $\mathrm{B}$, probably present in ground water as undissociated boric acid, is similar to $\mathrm{Cl}$ and $\mathrm{SO}_{4}$ in correlation with other chemical constituents and properties

These ion associations indicate that the ground water in the Chickies Quartzite (1) is contaminated with nitrogen and salts, especially $\mathrm{NaCl}$, from septic systems and(or) road salt; (2) partly reflects the weathering of Ca- and $\mathrm{Mg}$-bearing silicate minerals; (3) tends to be more dilute where more oxygenated; and (4) is acidic and contains more $\mathrm{Mn}, \mathrm{Ba}, \mathrm{SO}_{4}$, and $\mathrm{K}$ where concentrat ins of DOC are relatively high.

Spearman rho correlations are significant at the 95-percent confidence interval between spe ific capacity and $\mathrm{NO}_{3}\left(r_{\mathrm{s}}=0.70\right)$ and also between specific capacity and $\mathrm{Cl}\left(r_{\mathrm{s}}=0.39\right)$, suggesting that contaminant transport (of contaminants from surface sources, such as septic tanks and road salt) increases with increacing hydraulic conductivity. 
EXPLANATION

PERCENTAGE OF IONS IN MILLIEQUIVALENTS

LITHOLOGY

+ CONGLOMERATE

$\nabla$ QUARTZITE

$\otimes \quad$ SLATE

- SLATE-QuartZite

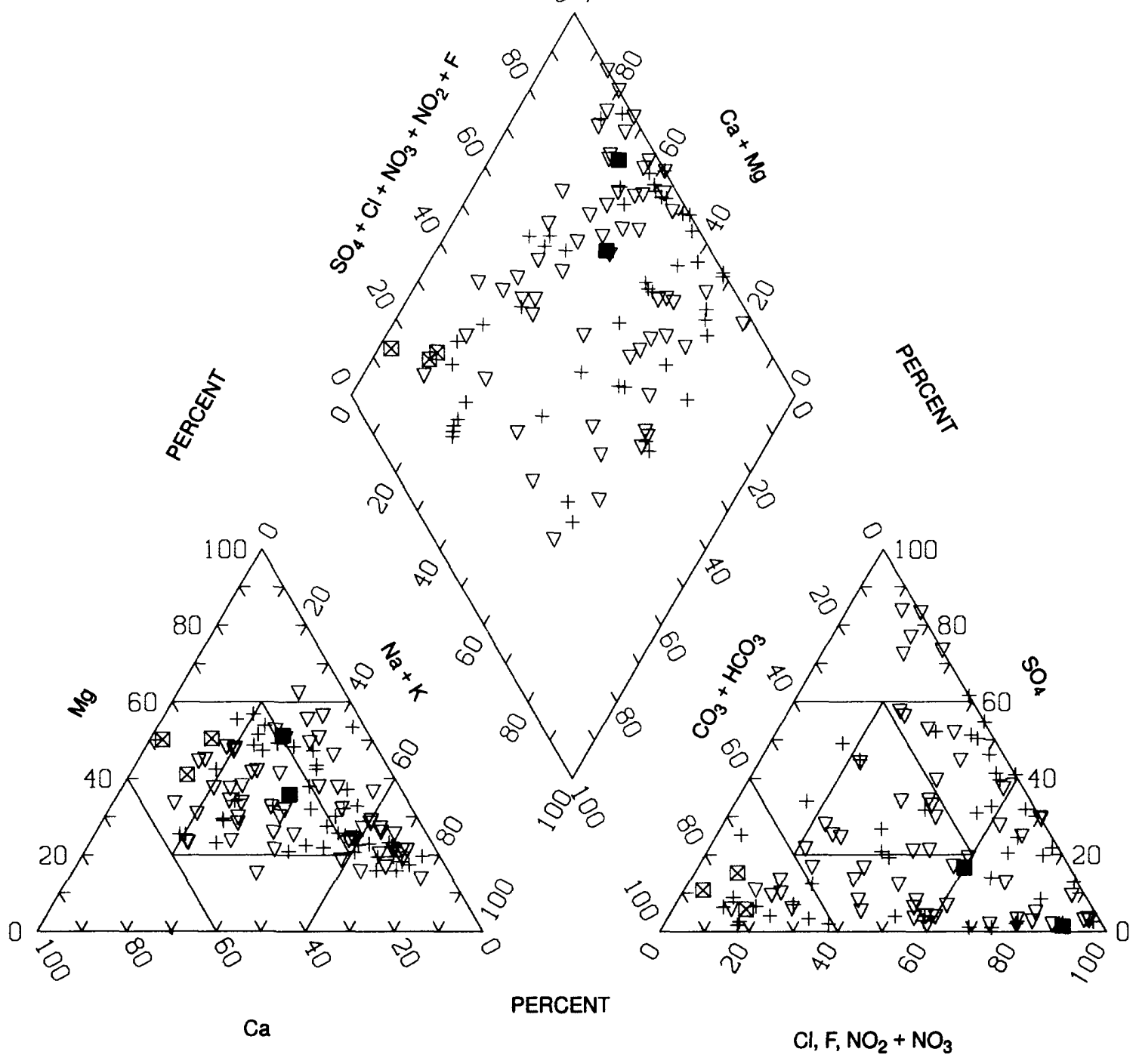

Figure 3. Chemical composition of ground water in the quartzite, conglomerate, slate, and slatequartzite lithologies of the Chickies Quartzite. 
EXPLANATION

PERCENTAGE OF IONS IN MILLIEQUIVALENTS

AREAS OF OUTCROP

$\oplus$ EASTERN

$\diamond$ CENTRAL

- WESTERN

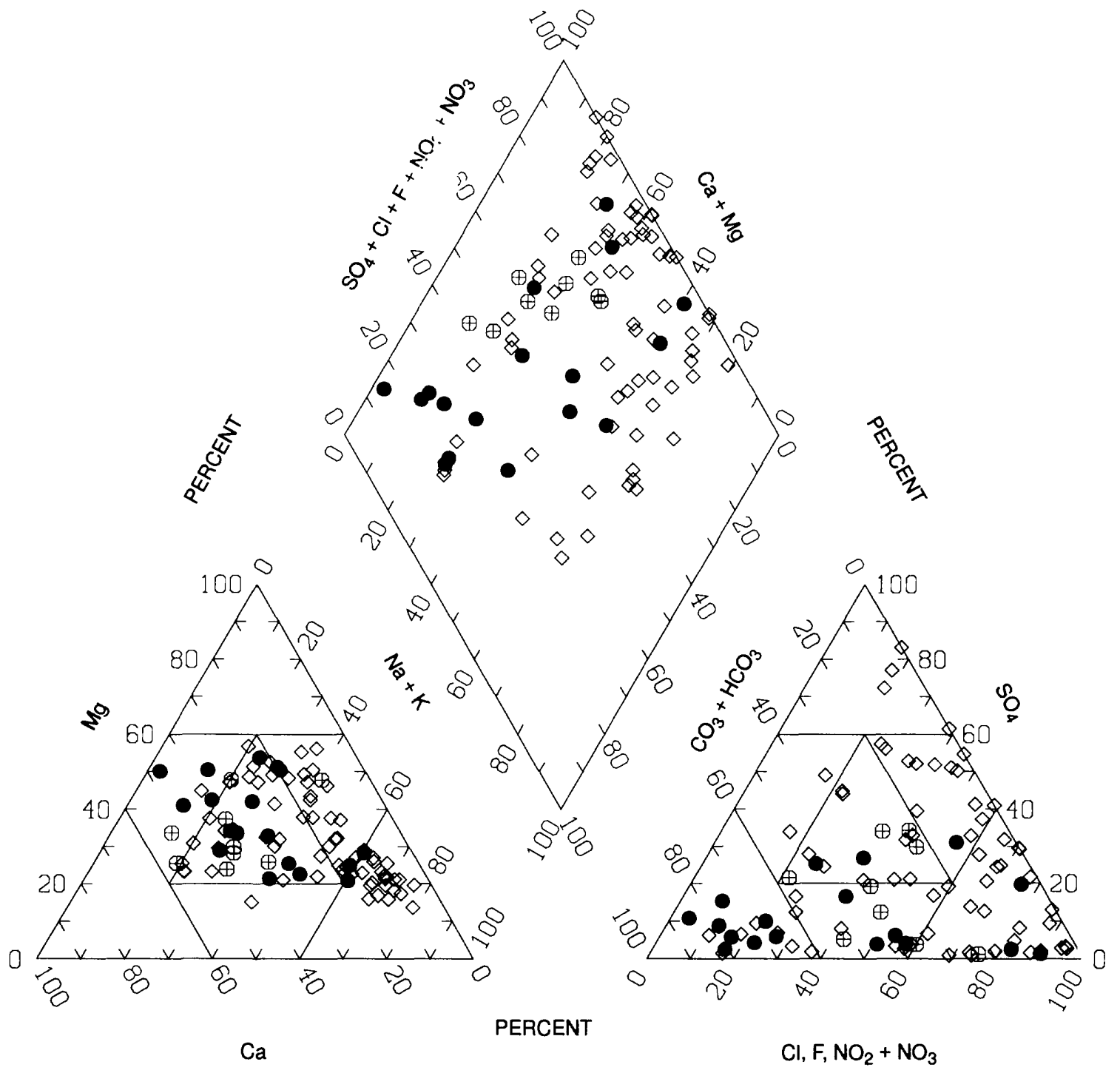

Figure 4. Chemical composition of ground water in the eastern, central, and western areas of outcrop of the Chickies Quartzite. 


\section{RADIUM AND RADON IN GROUND WATER}

Radionuclides are present in ground water in variable concentrations because sources are present and physical and chemical conditions favor mobilization or retardation specific radionuclides in the ground-water-flow system. In the Chickies Quartzite, minerals in the aquifer are the sour es of $R a$ and $R n$ in the ground water. Physical and chemical controls on the presence of $R a$ and $R n$ in ground water involve rock-water interactions and include aquifer mineralogy, chemical composit: $n$ of recharge, aquifer hydraulic conductivity, and paths of ground-water flow. In this study, the spatial distribution of elevated $\mathrm{Ra}$ and $\mathrm{Rn}$ activities in ground water is described and related to factors that include sources within the aquifer, and lithology, aquifer and well-construction characteristics, ground-water chemistry, and hydrogeologic setting.

Ra-226, Ra-228, and Rn-222 are naturally occurring radionuclides that belong to the U-238 and Th-232 decay series (fig. 5). U-238 and Th-232 are the most abundant naturally occurring isotor $:$ of $\mathrm{U}$ and $\mathrm{Th}$ and are the primary parents of the radioactive-decay series that ends in the stable iso ${ }^{+}$opes lead-206 (Pb-206) and lead-208 (Pb-208), respectively. U-238 and Th-232 have long half-lives and, therefore, decay slowly. Other radionuclides in the decay series have half-lives many orders of magnitude shorter and decay rapidly. Ra-226 and Rn-222 belong to the U-238 series and Ra-228 belongs to the Th-232 series. A short-lived $\mathrm{Rn}$ isotope, Rn-220, also belongs to the Th-232 series, but its activity is difficult to measure because of its short half-life of 55.6 seconds.

Radioactive decay proceeds with alpha- or beta-particle emission and accompanying release of energy through gamma-ray and other electromagnetic radiation. Alpha particles are heavy, highenergy particles that do not travel far because matter impedes their progress and absorbs the particles' energy. Alpha particles are composed of two protons and two neutrons and are emitted from the nucleus of a radionuclide undergoing alpha decay. Beta particles are lighter, lower-energy particles that travel greater distances than alpha particles and, like alpha particles, can transfer kinetic energy to matter. Beta particles are electrons (or positrons) that are derived from the transformation of a neutron to a proton (or proton to neutron) during beta- (or betat) decay. During radioactive decay, each radionuclide emits gamma rays of a specific energy and wavelength. Gamma radiation is not as effectively blocked by matter as are alpha and beta particles.

The activity of a radionuclide is a measure of the mass amount of the radionuclide and the rate of its decay. Activity is defined as being equal to $n \cdot \lambda$, where $n$ is the number of atoms of the radionuclide and $\lambda$ is the decay constant. The decay constant, $\lambda$, is equal to the natural $\log$ of 2 divided by the half-life of the radionuclide.

U-238 and Th-232 have fixed mass and activity ratios with their decay products in a closed system. A closed system can be defined as a given volume of solid, such as rock, or of a solid and liquid, such as rock and water, where no net gain or loss of radioactive decay products occurs by transport in or out of the system. Within a decay series, if no intermediate decay product is lost from the system, secular equilibrium is reached after a period dependent on the half-lives of isotopes in the series (approximately 10 half-lives of longest-lived intermediate radionuclide of the decay series). Secular equilibrium describes a state in which activities of all members of a decay series are equal, and mass ratios are fixed at some constant value. In an open system, transport of some decay products or parent radionuclides out of the system occurs, and secular equilibrium no longer prevails. Many ground-water systems are open systems at the local scale.

Differences in the chemical properties of radionuclides within a decay series may result in partitioning of the radionuclides within a closed physical-chemical system. If the system is open, partitioning of radionuclides may result in transport out of the system. Each isotope is chemically like any other isotope of the same element; conditions favoring mobility of $U$, for example, would equally favor mobility of U-238, U-234, and U-235. Physical mechanisms associated with radioactive denay, however, may cause one isotope to move in or out of a system more easily than another. For example, alpha recoil of the product nucleus in alpha decay (Friedlander and others, 1981) may promote ejection of U-234 from a solid (crystal structure or disordered surface condition). 


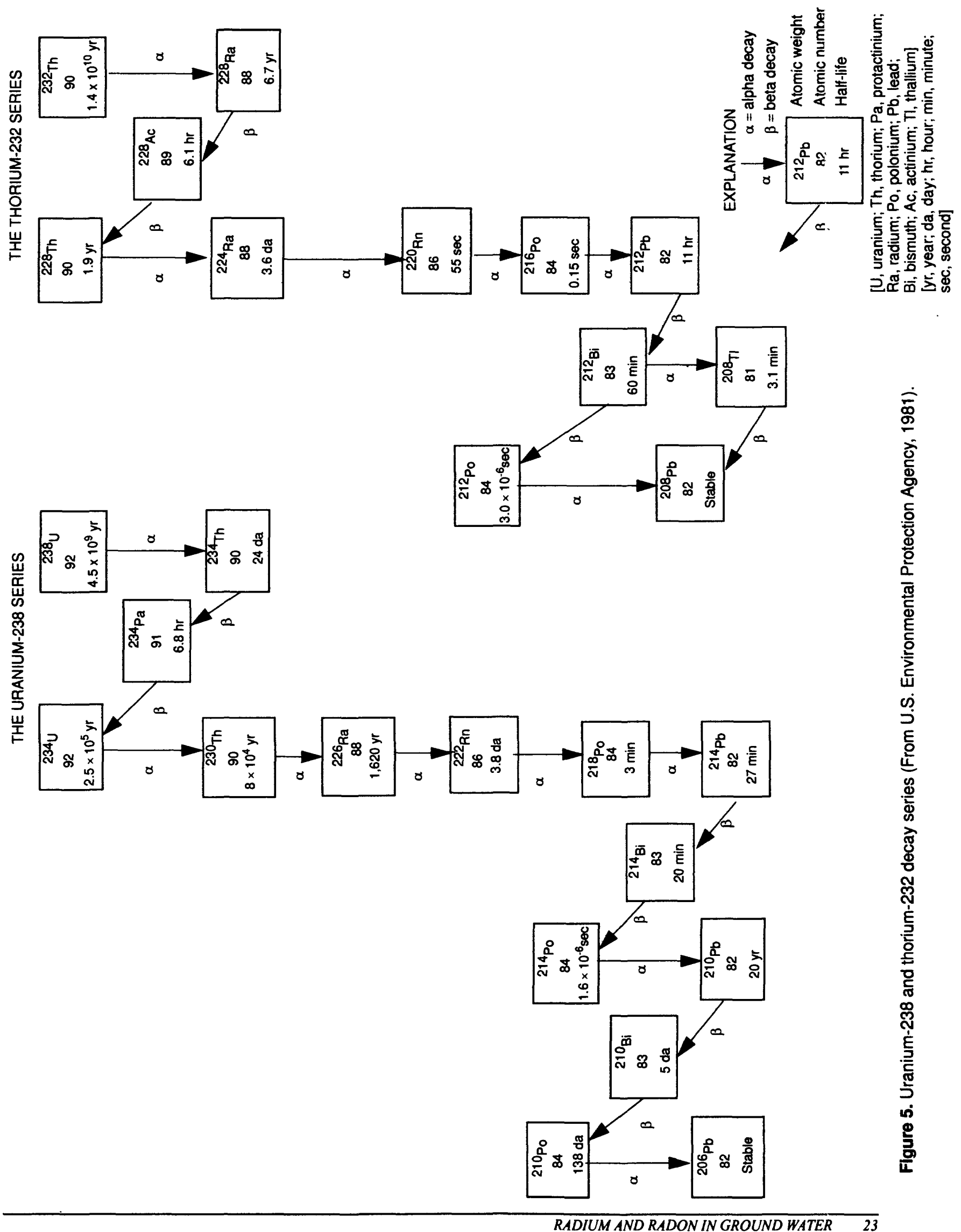


Generally, U, Th, and Ra are soluble under different geochemical conditions. $\mathrm{U}$ is most solt ble in oxidizing waters in the +6 oxidation state (especially as a uranyl complex $\mathrm{UO}_{2}{ }^{+}$) and in the +8 oxidation state (uranyl carbonates at $\mathrm{pH}$ greater than 8) (Langmuir, 1978). Th only is found ir the +4 oxidation state and has low solubility, but it is soluble in strongly acidic waters (Langmuir and Herman, 1980). Ra only is found in the +2 oxidation state and is most mobile in reducing, Cl-rick ground water with elevated TDS (Tanner, 1964). Solubility of $U$ and Th is strongly enhanced by complexation; the extent of Ra complexation is not well known (Langmuir and Riese, 1985).

\section{Sources in the Rocks of the Chickies Quartzite}

Solid-phase analysis of the Chickies Quartzite was conducted to determine sources of Ra and $\mathrm{Rn}$ in the ground water of the formation. Natural-gamma-ray geophysical logs were run in recently drilled wells to determine the vertical distribution of radioactivity in the formation and to identify radioactive zones or strata. Most logged wells were drilled during the study and, when possible, well cuttings were collected at 5 -ft intervals. Water from most of these wells was later sampled for laboratory analysis of chemical constituents, including Ra and U. Gamma-ray logs were used to select well-cutting samples for solid-phase analyses. Rock samples of the conglomerate, quartzite, and s'ate lithologies were collected at several quarries and road cuts and from cuttings of recently drilled wells. Results of rock-sample analyses for total Th and U; Ra-226, Ra-228, and some other radionuclide $s$ in the U-238 and Th-232 decay series; and potential mineral hosts for $U$ and $T h$ are discussed below.

Natural-gamma-ray logs were run in 31 wells penetrating the Chickies Quartzite, underlying Precambrian crystalline rocks, and Antietam Quartzite and Harpers Phyllite. The wells penetrating the Chickies Quartzite represent the conglomerate and quartzite lithologies in the western and central areas and include one well in the Hellam Hills in York County; 1 well on Gap Hill in Lanca ster County; 14 wells on Welsh Mountain in Lancaster and Chester Counties; and 5 wells, in the Barren Hills in Chester County (pl. 1). Natural-gamma-ray and caliper logs for all 31 wells are presented in the appendix.

Generally, the magnitude and distribution of natural-gamma-ray activity is related to lithology. The lowest measured natural-gamma-ray activity is associated with clean, white, pale pink, and gray quartzite that crops out in the Welsh Mountains and Barren Hills and corresponds to the quartz arenite facies of Hyde (1971). The maximum measured natural-gamma-ray activity is associated with the conglomerate that crops out in the Hellam Hills in York County and the Barren Hills in Chester County. Examples of the relations between lithology and gamma-ray logs are shown in figures 6-9.

The gamma-ray logs for wells drilled into the white, pale gray, and pink quartzite $(\mathrm{CH}-3166$, $\mathrm{LN}-1702, \mathrm{LN}-1703$, and upper sections of CH-3213, CH-3219, and CH-3315) show gamma activities of about $50 \mathrm{cps}$ (counts per second) and little variability. The gamma-ray logs for wells drilled into gray and dark-gray quartzite (CH-3160, CH-3305, and lower sections of $\mathrm{CH}-3213, \mathrm{CH}-3219$, and $\mathrm{CH}-3315$ ) and in rusty-colored quartzite (CH-3189 and LN-1716) show gamma activities up to $250 \mathrm{cps, \text {which }}$ are higher than "cleaner" quartzites. A down-section increase in gamma activity is shown on the log for well CH-3219 drilled into light and dark quartzite (fig. 6).

Natural-gamma-ray logs of the conglomerate include wells CH-3131, CH-3133, and YO-1172 and the upper sections of $\mathrm{CH}-3122$ and $\mathrm{CH}-3188$. Figure 7 shows that natural-gamma-ray logs of wells in the conglomerate (such as $\mathrm{CH}-3133$ and YO-1172) have rock that contains higher background and peak radioactivity than clean, white, pink and pale gray quartzite (such as wells LN-1702 ard CH-3166). Geophysical logging of well CH-3122 (fig. 8) identified increased gamma activity near the contact between the Chickies Quartzite and the underlying mafic gneiss. The lithologic log of the well describes a comparatively dark quartzite and conglomeratic quartzite containing small blue pebkles near the contact. Subsequent logging of wells LN-1713 (fig. 8) and LN-1715 located near the Chic'ries 
Quartzite-crystalline rock contact on Welsh Mountain in Lancaster County also indicated some increase in gamma activity near the contact, suggesting that the conglomerate is more radioactive than the overlying, cleaner quartzite. The magnitude of peak gamma activity in well $\mathrm{CH}-3122$ at a depth of about $210 \mathrm{ft}$, the largest peak observed, is more than twice that of the peak in well LN-1713. The logs of well CH-3188 (fig. 8), which penetrates the contact between the Chickies Quartzite and underlying crystalline rock, show a smaller increase in gamma activity near the contact, suggesting the concentration of gamma emitting material is variable. Lateral and vertical variability of radioactive and other minerals in the Chickies Quartzite reflects the original depositional variability of the sedimentary-rock precursor.

Natural-gamma-ray logs of wells drilled into the Harper's Phyllite and Antietam Quartzite in York County (YO-1169, YO-1170, and YO-1171) show that these rocks contain background and peak radioactivity similar to the dark gray quartzite of the Chickies Quartzite (fig. 9).

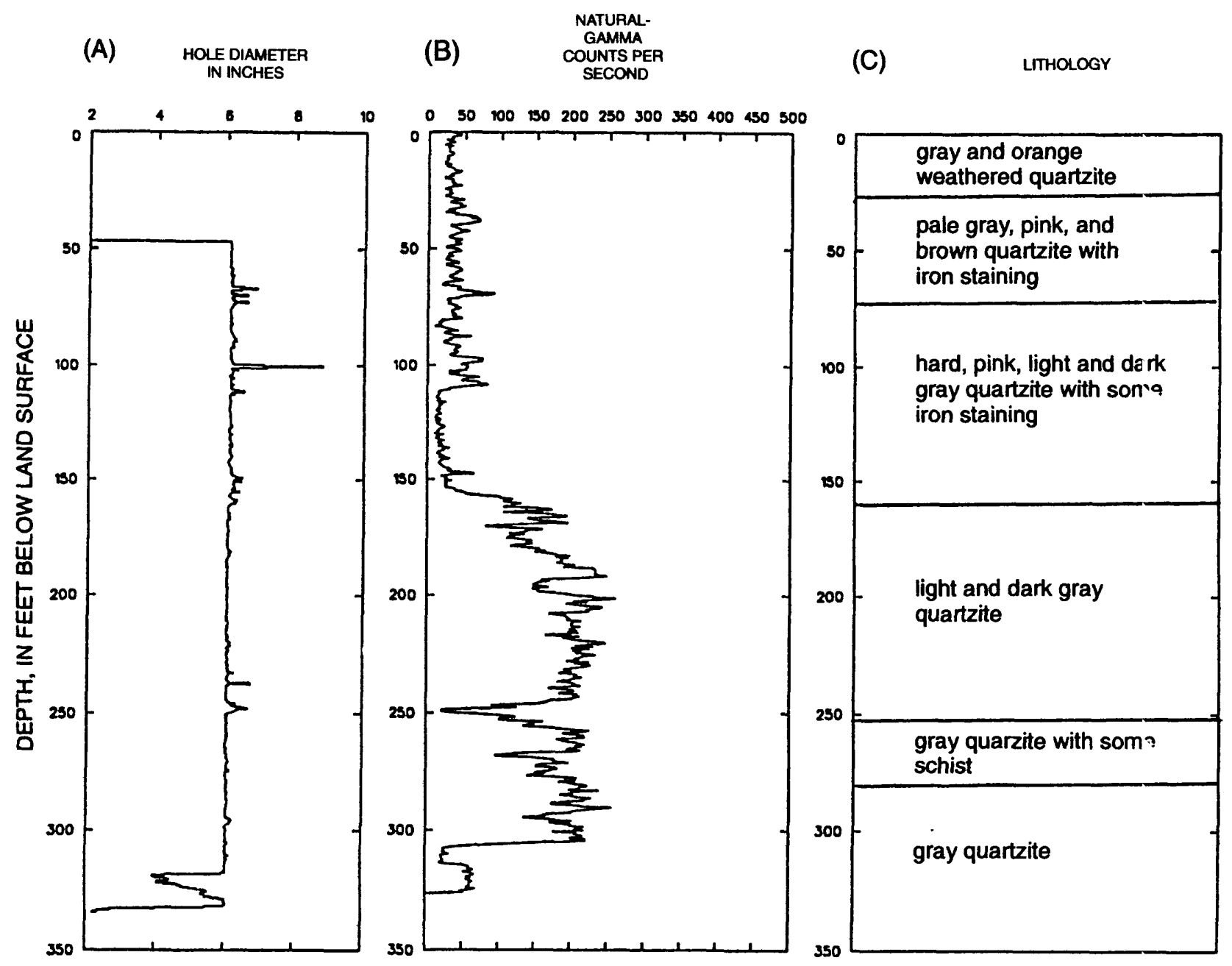

Figure 6. Caliper (A), natural-gamma-ray (B), and lithologic (C) logs for well $\mathrm{CH}-3219$. 


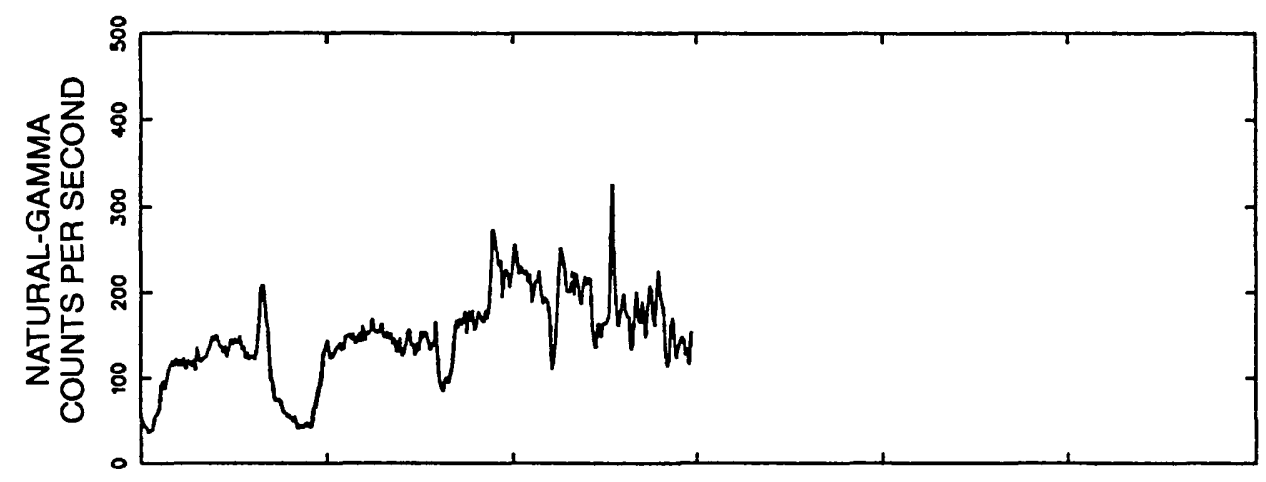

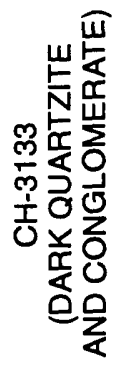
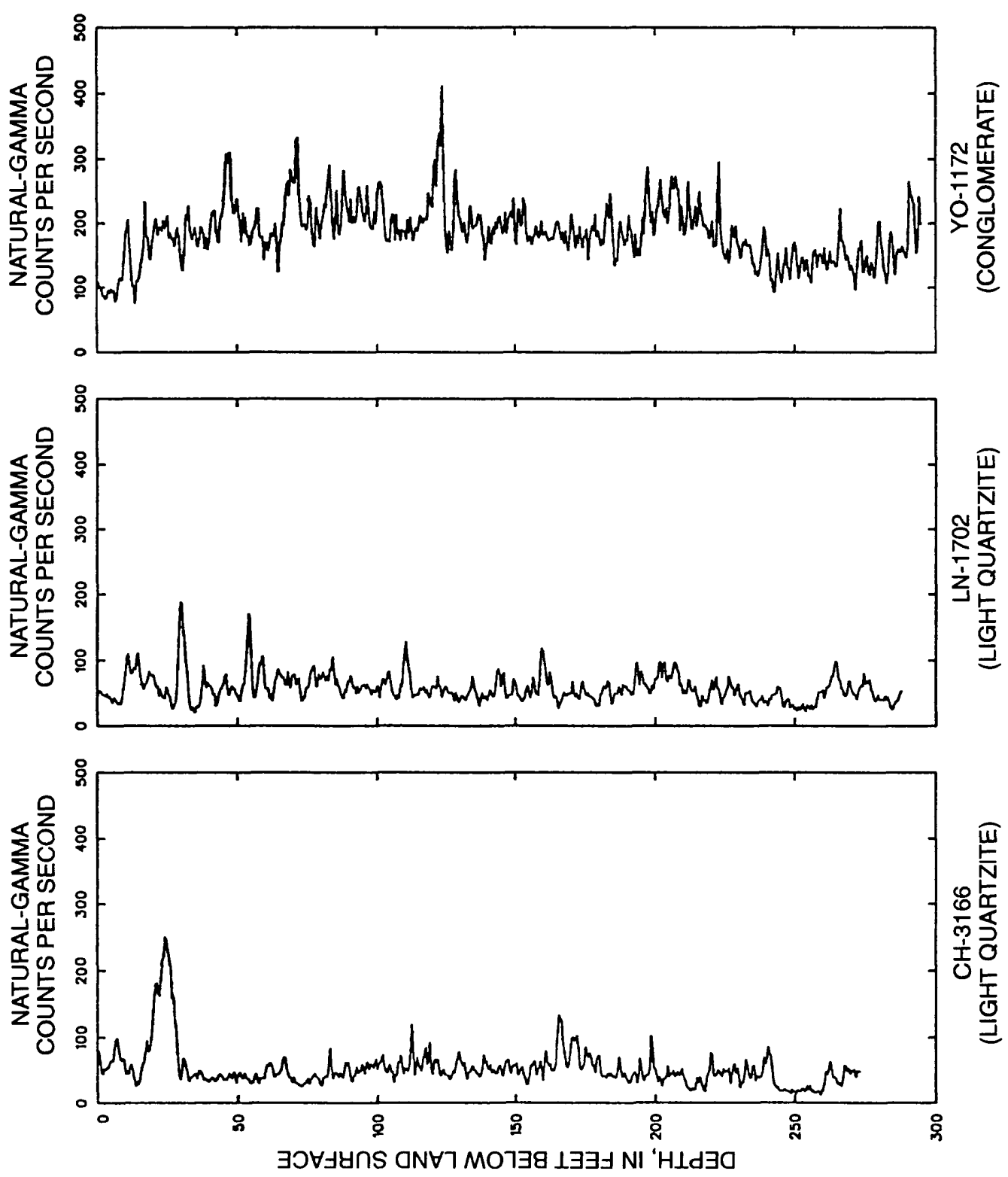

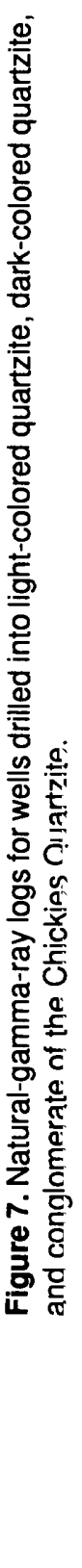




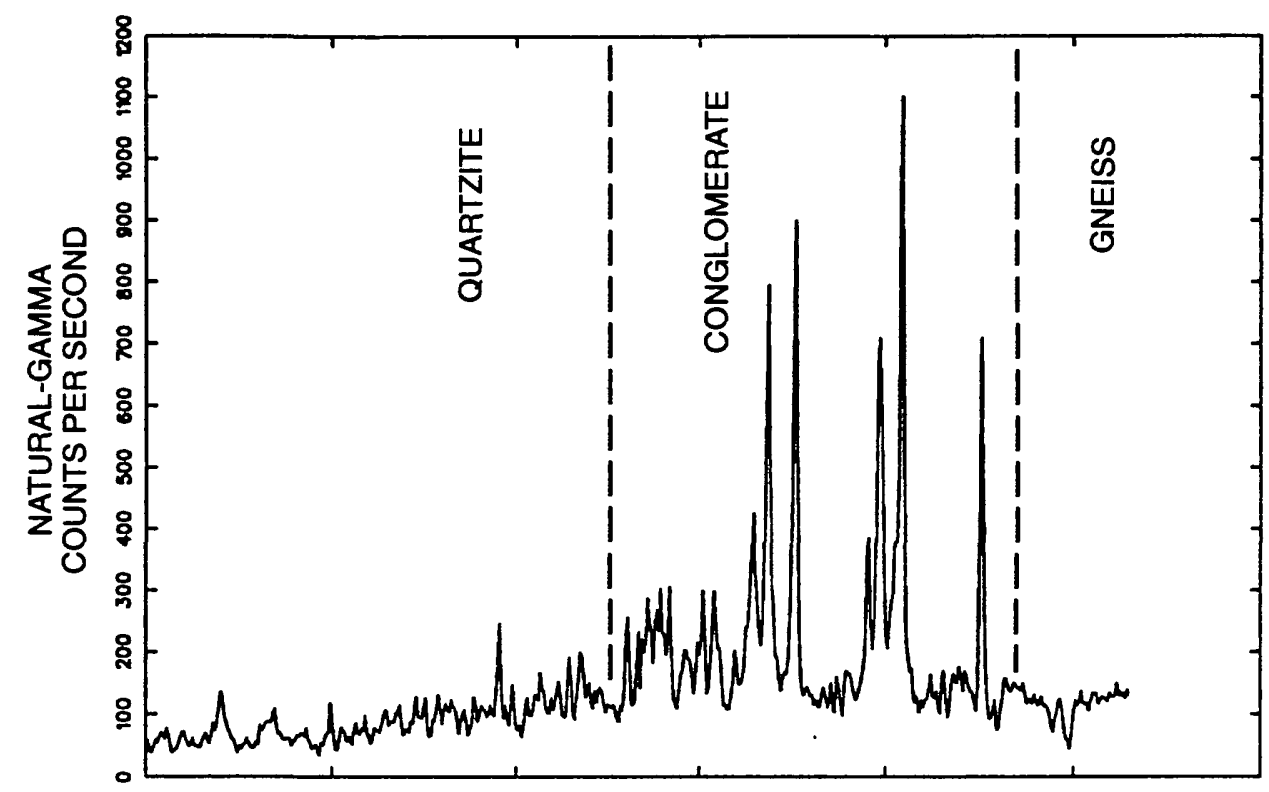

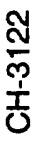

(1)
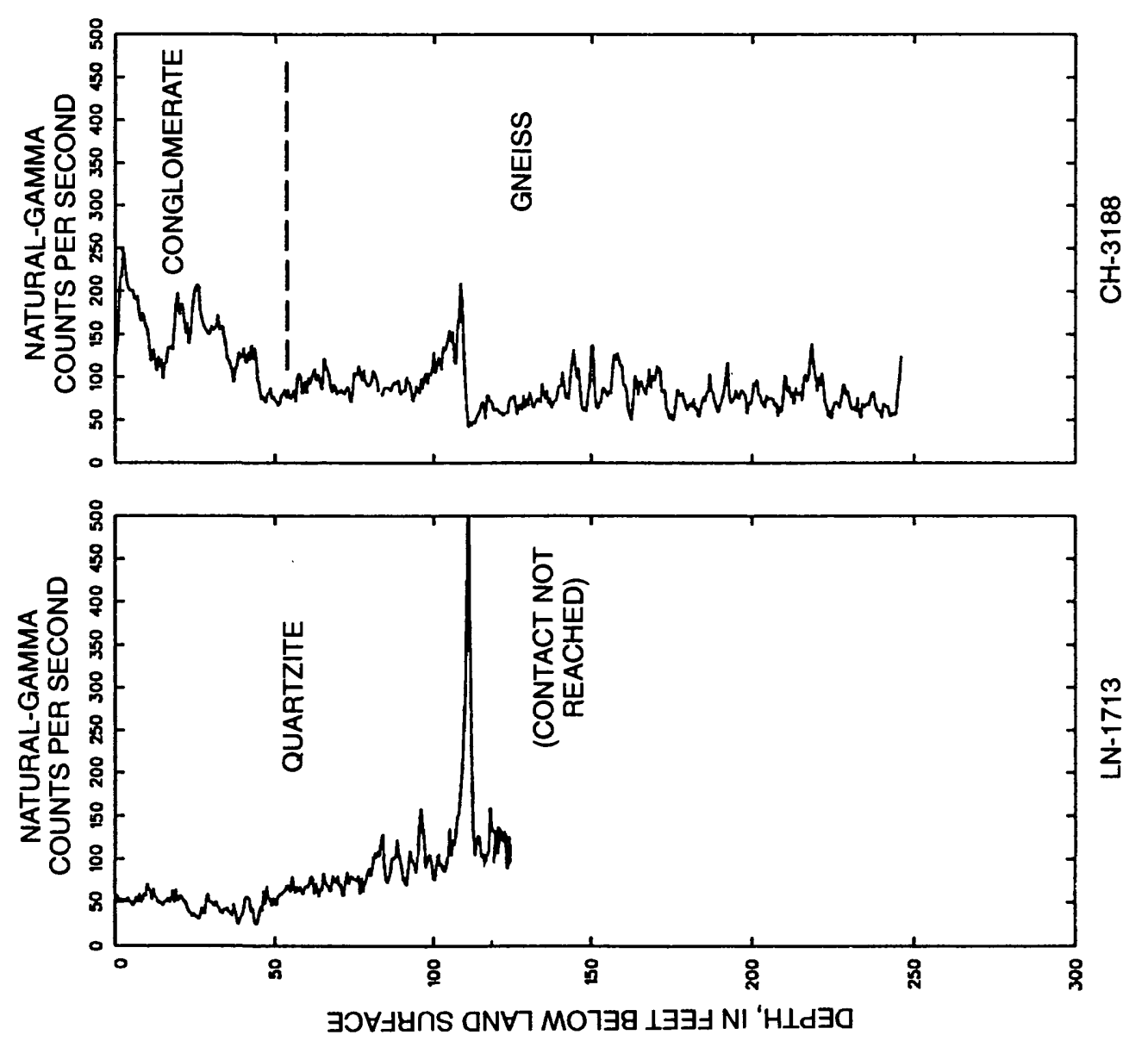

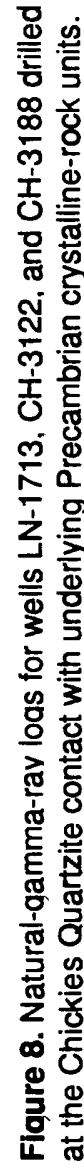



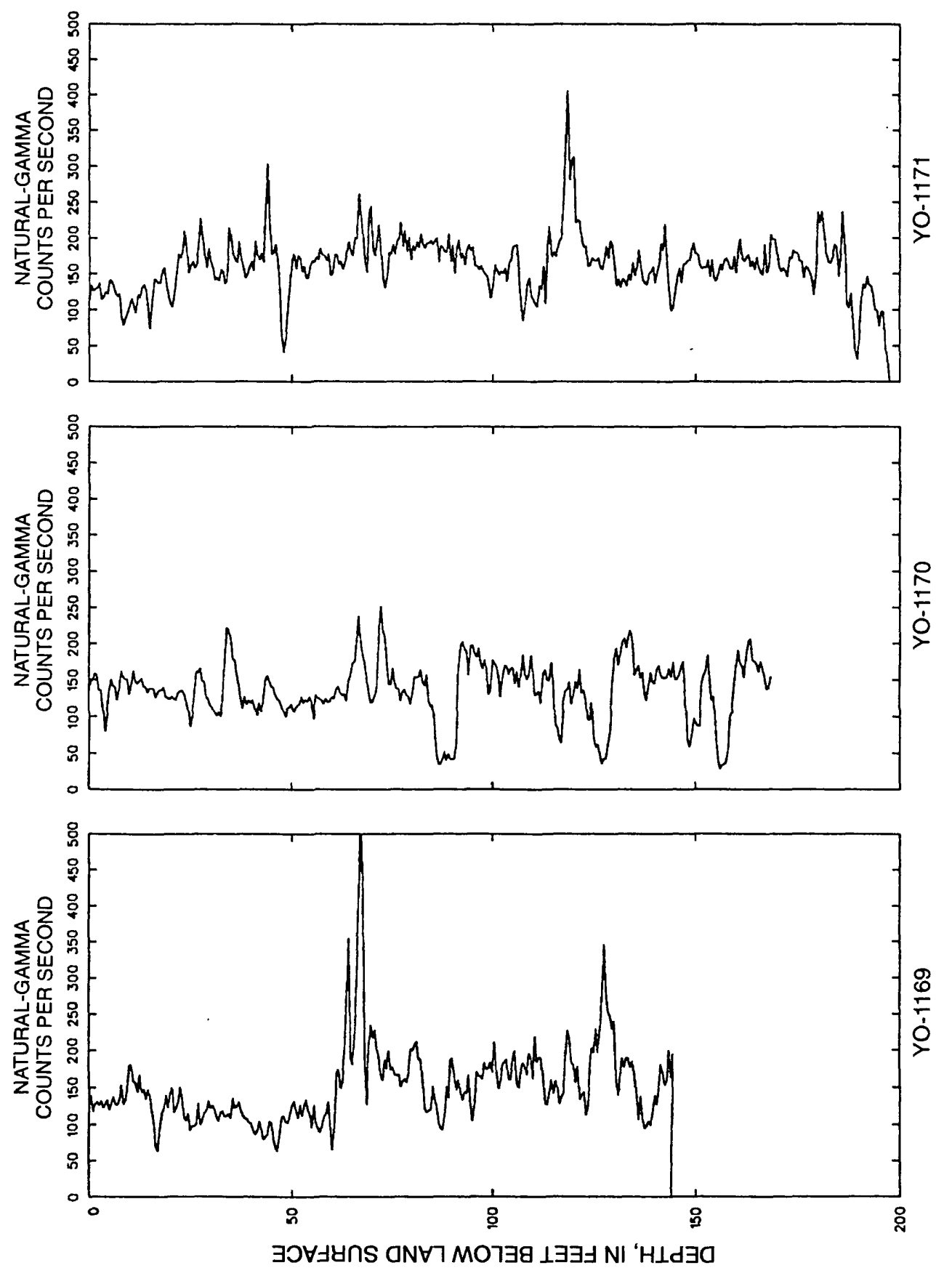

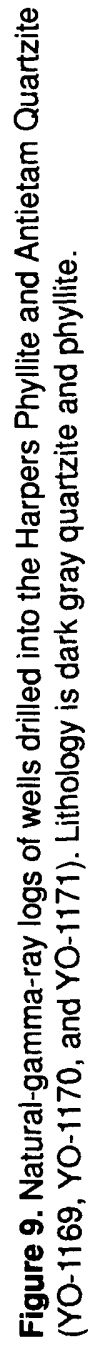




\section{Radioactive Elements and Isotopes}

Elevated activities of $R a$ and $R n$ in ground water may be associated with enriched concentrations of $\mathrm{U}, \mathrm{Th}$, or $\mathrm{Ra}$ in the mineral grains or matrix of the solid phase. In sandstone and quartzite, $U$ and Th are contained in detrital primary minerals and in secondary minerals. Detrital U- and Th-bearing primary minerals from crystalline source rocks, especially resistates such as zircon and monazite, may be concentrated in rocks by sedimentary processes. Primary minerals firm by crystallization during cooling of igneous melts and during metamorphism. Secondary mineralr form by precipitation from aqueous solutions containing dissolved components of primary minerals. The initial $U, T h$, and $R a$ content of rocks can be altered by subsequent diagenetic, metamorphic, and weathering processes that leach or deposit those elements. Migration of $U$, Th, and Ra causes enrichment or depletion of these elements in some rocks or zones within rocks.

Among sedimentary rocks, $U, T h$, and $R a$ contents are greater on the average in shales than in limestones, sandstones, and quartzites (table 7), although $U$ and Th enrichment is possible in all of these rock types (Durrance, 1986). Precambrian source rocks may have contained more $U$ than dn average rocks of younger ages (Durrance, 1986). Precambrian source rocks for the Chickies Quart rite could have included igneous, metamorphic, and sedimentary rocks, and reworked unconsolidated sediments.

Table 7. Average uranium and thorium content of the earth's crust and some sedimentary and igneous rocks (from Durrance, 1986, p. 31-33)

[ppm, parts per million]

\begin{tabular}{|c|c|c|c|c|}
\hline & $\begin{array}{c}\text { Th } \\
\text { (ppm) }\end{array}$ & $\underset{(p p m)}{U}$ & $\begin{array}{c}T h / U^{1} \\
\text { mass ratio }\end{array}$ & $\begin{array}{c}\mathrm{Th} / \mathrm{U}^{2} \\
\text { activity } \\
\text { ratio }\end{array}$ \\
\hline Earth's crust & 8.5 & 2.7 & 3.2 & 1.1 \\
\hline Sandstone & 1.7 & .45 & 3.8 & 1.3 \\
\hline Shale & 12 & 3.7 & 3.2 & 1.1 \\
\hline Limestone & 1.7 & 2.2 & .8 & .3 \\
\hline Basalt & 4 & 1 & 4.0 & 1.3 \\
\hline
\end{tabular}

${ }^{1}$ Mass ratio calculated from average Th and $U$ values.

2 Activity ratio calculated by use of the approximation that the activity of $9 \mathrm{ppm} \mathrm{Th}=1 \mathrm{pCi} / \mathrm{g}$ and the activity of $3 \mathrm{ppm} \mathrm{U}=1 \mathrm{pCi} / \mathrm{g}$, assuming most Th is Th-232 and most $U$ is U-238. 


\section{Uranium and thorium}

Rock samples of the Chickies Quartzite were analyzed for $U$ and Th to determine the concentrations of $U$ and $T h$ in the formation and the relation between $U$ and $T h$ concentrations in the rock and Ra-226, Ra-228, and Rn-222 activities in the ground water. Analyses for activities of radionuclides in the U-238 and Th-232 decay series, including Ra-226 and Ra-228, may indicate whether or not secular equilibrium is maintained, the degree of secular disequilibrium, and whether preferential leaching or accumulation of radionuclides is suggested.

Rock samples and well cuttings analyzed for $U$ and Th were collected in different geograpl ic areas and are from outcrops and subsurface rocks of different lithologies of the Chickies Quartzite and adjacent geologic units. Sample locations of seven rock samples from six quarries in the quartzite and five hand samples from four outcrops of the quartzite, conglomerate, and slate lithologies of Chickies Quartzite are shown in figure 10. Well cuttings are from 18 wells drilled into the Chickies Quartzite, underlying crystalline rock and overlying phyllite and quartzite in the central and western areas of outcrop (pl. 1). Because well-cutting samples were not selected randomly and the limiter number of sample sites and samples per site and lithology, rock samples may not be representative of the formations and provide only reconnaissance data on $U$ and Th content.

Forty-one samples of well cuttings from 18 wells were analyzed, including samples from several different depths in 10 wells. Eight wells were drilled into the quartzite lithology and six were drilled into the conglomerate lithology of the Chickies Quartzit, , ine was drilled through the Chickies Quartzite into underlying crystalline rock, and three weie drilled into the Antietam Quartzite and Harpers Phyllite. Well cuttings generally are a composite sample of a 5-ft drilling interval. Most cuttings were selected from zones where geophysical logs showed elevated gamma activity. For comparison, a few samples from zones with low gamma-ray activity also were analyzed.

All of the 12 quarry samples are quartzite or sericitic quartz schist. Two quarries in Chester County, the Valley Forge quarry in Honeybrook and the Green Gold quarry in Parkesburg, are artive; the others are inactive. Samples from the Valley Forge quarry-screen pile are assumed to be representative of the bulk composition of the formation in the quarry area. All other quarry and rock samples were single hand samples and may not be representative of the formation at the site.

The concentrations of $U$ and Th in rock samples and well cuttings of the Chickies Quartzite and adjacent geologic units are given in table 8 and are summarized for the Chickies Quartzite samples in table 9. The highest Th and $U$ concentrations analyzed in samples of the Chickies Quartzite are from zones of peak gamma activity associated with conglomerate near the crystalline-rock contact in well CH-3122 (fig. 11) and were $61 \mathrm{ppm}$ Th and $8.1 \mathrm{ppm}$ U. The lowest Th and U concentrations are from a zone of low gamma activity associated with light quartzite in well CH-3315 (fig. 11) and were $2.2 \mathrm{ppm}$ $T h$ and $0.8 \mathrm{ppm} U$. The $U$ and Th concentrations in quartzite and conglomerate rock samples from the Chickies Quartzite are greater than those concentrations for average sandstones; and the U and Th concentrations in the slate lithology samples of the Chickies Quartzite are similar to those in an average shale (table 7).

Analyses of the quarry, rock, and well-cutting samples suggest that $U$ content of the litholngies of the Chickies Quartzite in all areas varies less than the Th content, especially in the conglomerate. Some samples of the conglomerate are enriched in Th with respect to $U$, as indicated by Th concentrations and $\mathrm{Th} / \mathrm{U}$ activity ratios greater than the mean crustal average (table 7). Elevate $\mathrm{Th}$ concentrations in sandstones may be associated with the presence of heavy minerals, such as monazite (Durrance, 1986). Average Th/U activity for rocks with crustal abundance of $U$ and $T h$ is about 1.1, although estimates range as great as 1.6 (Mason, 1958); most samples of the Chickies Quartzite have $\mathrm{Th} / \mathrm{U}$ activity ratios in this range. Generally, the $\mathrm{Th} / \mathrm{U}$ mass and activity ratio is greatest in the conglomerate, comparatively less in the slate, and least in the quartzite. In the quartzite lithology, the dark quartzite and sericitic quartz schist samples have a higher $\mathrm{Th} / \mathrm{U}$ mass ratio than clean quartzite. 

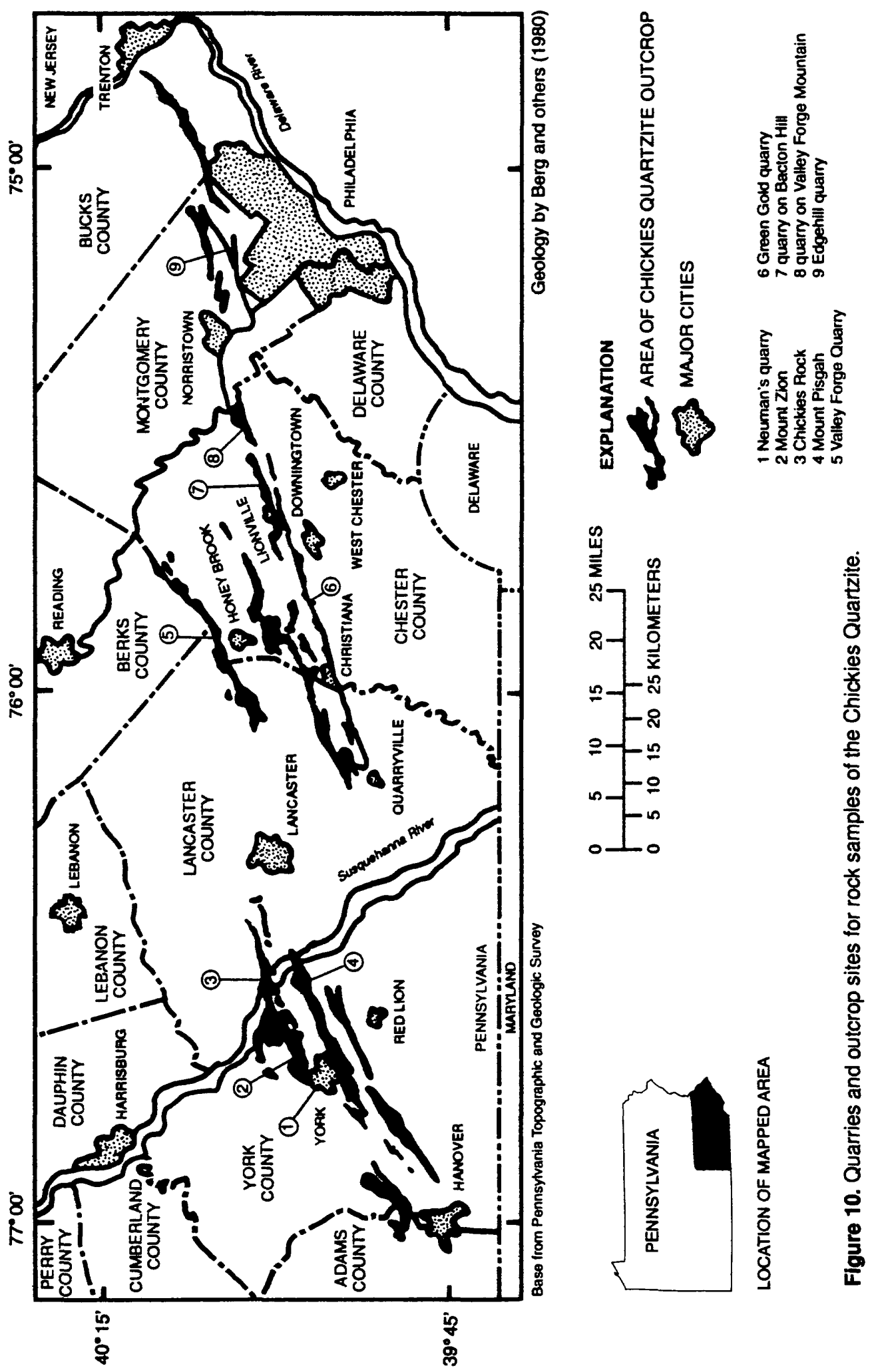
Table 8. Uranium and thorium content of well cuttings and rock samples determined by neutron activation analysis

[ppm, parts per million; Єc, Chickies Quartzite; Єah, Harper's Phyllite and Antietam Quartzite, undivided; Yhma, mafic gneiss; --, no data]

\begin{tabular}{|c|c|c|c|c|c|c|}
\hline $\begin{array}{c}\text { Well } \\
\text { number }\end{array}$ & $\begin{array}{l}\text { Depth of } \\
\text { sample } \\
\text { (feet }\end{array}$ & $\begin{array}{c}\text { Th } \\
\text { (ppm) }\end{array}$ & $\underset{(p p m)}{U}$ & $\begin{array}{c}\text { Th/U } \\
\text { mass ratio }\end{array}$ & $\begin{array}{l}\text { Geologic } \\
\text { unit }\end{array}$ & Lithology \\
\hline \multicolumn{7}{|c|}{ Well cuttings } \\
\hline $\mathrm{CH}-3122$ & 105 & 9.3 & 6.8 & 1.4 & $€ c$ & conglomerate \\
\hline CH-3122 & 175 & 31 & 5.2 & 6.0 & $€ c$ & conglomerate \\
\hline CH-3122 & 205 & 43 & 6.6 & 6.5 & $€ c$ & conglomerate \\
\hline CH-3122 & 210 & 61 & 8.1 & 7.5 & $\epsilon c$ & conglomerate \\
\hline CH-3122 & 235 & 6.8 & 2.1 & 3.2 & $\epsilon_{c}$ & conglomerate \\
\hline CH-3122 & 265 & .5 & .6 & .8 & Yhma & mafic gneiss \\
\hline CH-3122 & 275 & .4 & 2.3 & .2 & Yhma & mafic gneiss \\
\hline CH-3131 & 135 & 12 & 4.3 & 2.8 & $\epsilon c$ & conglomerate \\
\hline CH-3133 & 115 & 4.9 & 2.3 & 2.1 & $\epsilon c$ & conglomerate \\
\hline CH-3133 & 135 & 11 & 2.9 & 3.8 & $\epsilon_{c}$ & conglomerate \\
\hline CH-3133 & 140 & 5.3 & 2.4 & 2.2 & $\epsilon_{c}$ & conglomerate \\
\hline CH-3133 & $145-150$ & 5.6 & 2.3 & 2.4 & $\epsilon_{c}$ & conglomerate \\
\hline CH-3166 & $225-230$ & 3.9 & 1.2 & 3.3 & $\epsilon_{c}$ & quartzite (light) \\
\hline CH-3189 & 75 & 13 & 3.2 & 4.1 & $€ c$ & quartzite (rusty) \\
\hline $\mathrm{CH}-3213$ & $180-185$ & 7.6 & 2.7 & 2.8 & $\epsilon_{c}$ & quartzite (dark) \\
\hline $\mathrm{CH}-3213$ & $205-210$ & 13 & 3.2 & 4.1 & $\epsilon_{c}$ & quartzite (dark) \\
\hline CH-3213 & $210-215$ & 16 & 4.3 & 3.7 & $\epsilon c$ & quartzite (dark) \\
\hline CH-3219 & $90-95$ & 4 & 1.4 & 2.9 & $\epsilon_{c}$ & quartzite (light) \\
\hline CH-3219 & $205-210$ & 13 & 3.2 & 4.1 & $\epsilon_{c}$ & quartzite (dark) \\
\hline CH-3219 & $295-300$ & 10 & 3.4 & 2.9 & $€ c$ & quartzite (dark) \\
\hline $\mathrm{CH}-3305$ & $125-130$ & 10 & 3.7 & 2.7 & $€ c$ & quartzite (dark) \\
\hline CH-3305 & $135-140$ & 7.6 & 2.6 & 2.9 & $\epsilon_{c}$ & quartzite (dark) \\
\hline CH-3315 & 100 & 2.2 & .8 & 2.8 & $\epsilon_{c}$ & quartzite light) \\
\hline CH-3315 & 170 & 15 & 3.8 & 4.0 & $€ c$ & quartzite (dark) \\
\hline CH-3315 & 200 & 11 & 3.6 & 3.1 & $€ c$ & quartzite (dark) \\
\hline CH-4146 & -- & 15 & 4.0 & 3.8 & $\epsilon_{c}$ & conglomerate \\
\hline LN-1702 & $221-226$ & 4.8 & 1.8 & 2.7 & $\epsilon_{c}$ & quartzite (light) \\
\hline LN-1713 & 115 & 13 & 3 & 4.3 & $\epsilon_{c}$ & conglomerate \\
\hline LN-1713 & 120 & 5.4 & 1.9 & 2.8 & $€ c$ & conglomerate \\
\hline LN-1715 & $110-115$ & 6.2 & 6.2 & 1 & $\epsilon_{c}$ & conglomerate \\
\hline LN-1715 & $120-125$ & 7.5 & 2.6 & 2.9 & $\epsilon_{c}$ & conglomerate \\
\hline $\mathrm{LN}-1716$ & 55 & 13 & 3.9 & 3.3 & $\epsilon_{c}$ & quartzite (rusty) \\
\hline LN-1716 & 98 & 13 & 4.5 & 2.9 & $\epsilon_{c}$ & quartzite (rusty) \\
\hline YO-1169 & $70-75$ & 31 & 5.7 & 5.4 & Єah & quartzite-phyllite \\
\hline YO-1170 & $105-110$ & 13 & 3.6 & 3.6 & €ah & quartzite-phyllite \\
\hline YO-1171 & $125-130$ & 20 & 4.5 & 4.4 & Єah & quartzite-phyllite \\
\hline YO-1172 & $130-135$ & 20 & 2.6 & 7.7 & $\epsilon_{c}$ & conglomerate \\
\hline YO-1172 & $200-205$ & 10 & 2.2 & 4.6 & $\epsilon_{c}$ & conglomerate \\
\hline YO-1172 & $210-215$ & 10 & 2.2 & 4.6 & $\epsilon_{c}$ & conglomerate \\
\hline YO-1172 & $215-220$ & 16 & 4 & 4 & $€ c$ & conglomerate \\
\hline YO-1172 & $260-265$ & 10 & 1.7 & 5.9 & $€ c$ & conglomerate \\
\hline
\end{tabular}


Table 8. Uranium and thorium content of well cuttings and rock samples determined by neutron activation analysis --Continued

\begin{tabular}{|c|c|c|c|c|c|}
\hline Sample location & $\begin{array}{c}\text { Th } \\
(\mathrm{ppm})\end{array}$ & $\underset{(p p m)}{U}$ & $\begin{array}{c}\mathrm{Th} / \mathrm{U} \\
\text { mass ratio }\end{array}$ & $\begin{array}{c}\text { Geologic } \\
\text { unit }\end{array}$ & Lithology \\
\hline \multicolumn{6}{|l|}{ Quarry rocks and hand samples } \\
\hline Valley Forge Quarry & 8.2 & 3.1 & 2.7 & $€ c$ & quartzite (light) \\
\hline Valley Forge Quarry & 5.8 & 3.1 & 1.9 & $€ c$ & quartzite (light) \\
\hline Green-Gold Quarry & 5.3 & 1.6 & 3.3 & $€ c$ & sericitic schist \\
\hline Neuman's Quarry & 5.5 & 2.3 & 2.4 & $\epsilon c$ & quartzite (light) \\
\hline Quarry on Bacton Hill & 3.1 & 1.6 & 1.9 & $\epsilon c$ & quartzite (light) \\
\hline Quarry near Valley Forge & 5.8 & 2.8 & 2.1 & $\epsilon c$ & quartzite (light) \\
\hline Quarry on Edgehill Rd. & 9.6 & 1.7 & 5.7 & $€ c$ & sericitic schist \\
\hline Chickies Rock & 3.9 & 1.2 & 3.3 & $\epsilon c$ & quartzite (light) \\
\hline Mt. Zion & 40 & 2.8 & 14 & $\epsilon c$ & conglomerate \\
\hline Mt. Pisgah & 14 & 2.8 & 5 & $€ c$ & slate \\
\hline Mt. Pisgah & 13 & 3 & 4.3 & $\epsilon c$ & slate \\
\hline Bacton Hill & 29 & 2.7 & 11 & $\epsilon c$ & conglomerate. \\
\hline
\end{tabular}

Table 9. Summary of uranium and thorium content of well cuttings and rock samples of the conglomerate, quartzite, and slate lithologies of the Chickies Quartzite

[ppm, parts per million]

\begin{tabular}{|c|c|c|c|c|c|}
\hline Sample source & $\begin{array}{l}\text { Number of } \\
\text { samples }\end{array}$ & $\begin{array}{c}\text { Th (ppm) } \\
\text { Range } \\
\text { Median }\end{array}$ & $\begin{array}{l}\text { U (ppm) } \\
\text { Range } \\
\text { Median }\end{array}$ & $\begin{array}{c}\text { Th/U } \\
\text { mass ratio } \\
\text { Range } \\
\text { Median }\end{array}$ & $\begin{array}{c}\text { Th/U } \\
\text { activity ratio } \\
\text { Range } \\
\text { Median }\end{array}$ \\
\hline \multicolumn{6}{|l|}{ Well cuttings } \\
\hline \multirow[t]{2}{*}{ Quartzite (light) } & 4 & $2.2-4.8$ & $0.8-1.8$ & $2.7-3.3$ & $0.9-1.1$ \\
\hline & & 4.0 & 1.3 & 2.9 & 1.0 \\
\hline \multirow[t]{2}{*}{ Quartzite (dark) } & 12 & $7.6-16$ & $2.6-4.5$ & $2.7-4.1$ & $.9-1.4$ \\
\hline & & 13 & 3.5 & 3.2 & 1.1 \\
\hline \multirow[t]{2}{*}{ Conglomerate } & 20 & $4.9-60$ & $1.7-8.1$ & $1.0-7.7$ & $.3-2.6$ \\
\hline & & 10 & 2.8 & 3.9 & 1.3 \\
\hline \multicolumn{6}{|c|}{ Quarry rocks and hand samples } \\
\hline \multirow[t]{2}{*}{ Quartzite (light) } & 6 & $3.1-8.2$ & $1.2-3.1$ & $1.9-3.3$ & $.6-1.1$ \\
\hline & & 5.7 & 2.6 & 2.3 & .8 \\
\hline \multirow[t]{2}{*}{ (schist) } & 2 & $5.3-9.6$ & $1.6-1.7$ & $3.3-5.7$ & $1.1-1.9$ \\
\hline & & 7.4 & 1.7 & 4.5 & 1.5 \\
\hline \multirow[t]{2}{*}{ Conglomerate } & 2 & $29-40$ & $2.7-2.8$ & $11-14$ & $3.6-4.8$ \\
\hline & & 35 & 2.8 & 13 & 4.0 \\
\hline \multirow[t]{2}{*}{ Slate } & 2 & $13 \cdot 14$ & $2.8-3.0$ & $4.3-5.0$ & $1.4 \cdot 1.7$ \\
\hline & & 14 & 2.9 & 4.7 & 1.6 \\
\hline
\end{tabular}

${ }^{1}$ Activity ratio calculated by use of the approximation that the activity of $9 \mathrm{ppm} \mathrm{Th}=1 \mathrm{pCi} / \mathrm{g}$ and the activity of $3 \mathrm{ppm} \mathrm{U}=1 \mathrm{pCi} / \mathrm{g}$. 


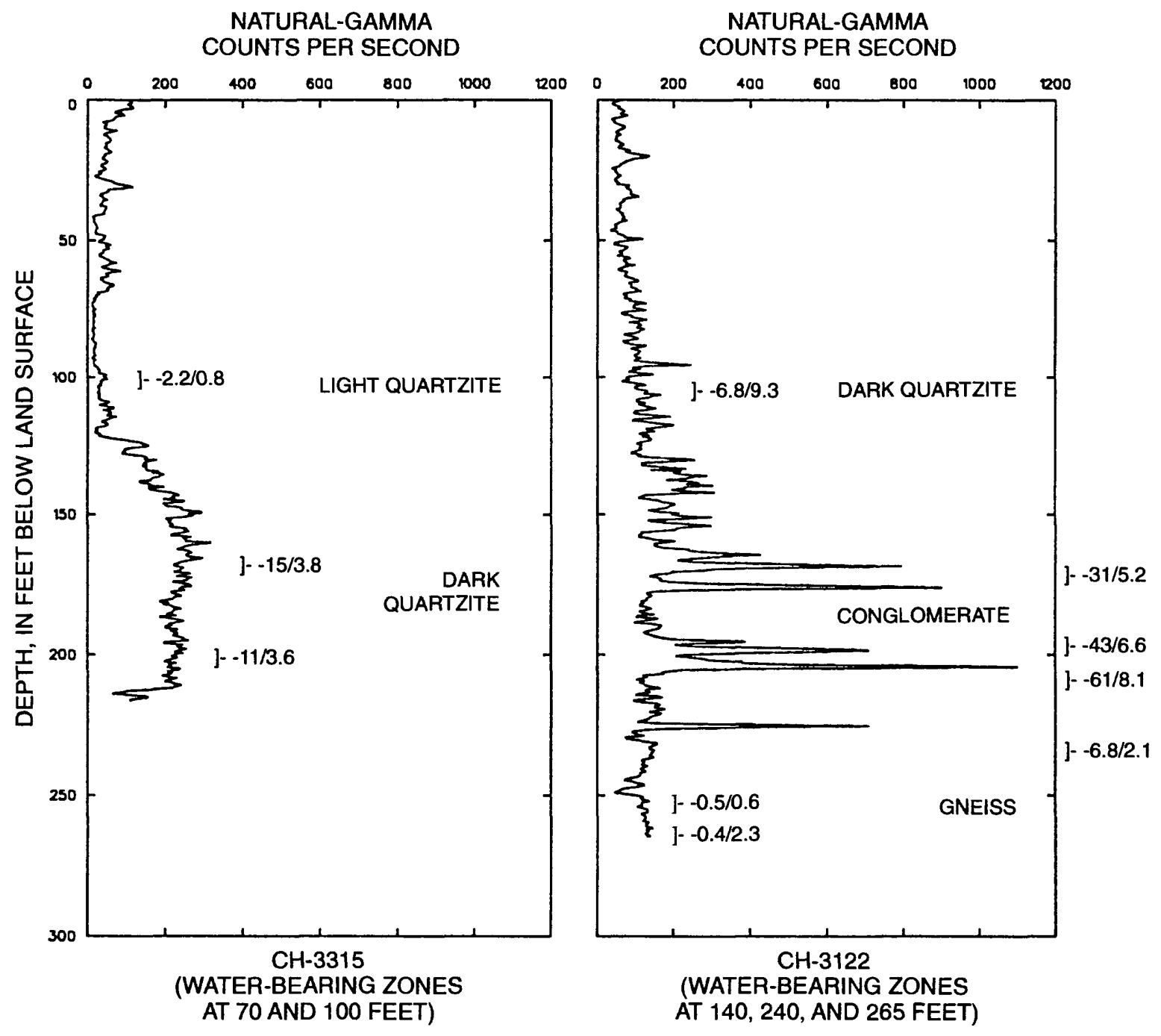

Figure 11. Natural-gamma-ray logs of wells $\mathrm{CH}-3315$ and $\mathrm{CH}-3122$. Annotated values are thorium/uranium content in parts per million for well cuttings from indicated depth intervals.

For comparison, well cuttings from geologic units adjacent to the Chickies Quartzite were analyzed (table 8). Low $U$ and Th concentrations were measured in well cuttings of mafic gneiss (well $\mathrm{CH}-3122$ at depths of 265 and $275 \mathrm{ft}$ ), the underlying crystalline rock in the Barren Hills of the central area; the low concentrations are consistent with the average for mafic rocks (basalt, $\operatorname{tak}^{1} \mathrm{e}$ 7). The $U$ and Th content of the Harpers Phyllite and Antietam Quartzite well cuttings from York Co'inty (YO-1169, YO-1170, and YO-1171) are as great or greater than content of the Chickies Quartzite. 


\section{U-238 and Th-232 decay series radionuclides}

Secular equilibrium can be determined by comparing the activities of members within the U-238 or Th-232 decay series. In the absence of secular equilibrium, inferences may be drawn about the losses from or gains to the solid phase in the aquifer. In a natural ground-water system, loss of radionuclides from the rock can occur by alpha recoil, dissolution of minerals, and radon gas emanation.

The first radionuclide in the U-238 decay series measured by gamma-ray spectrometry is Th-234, the product of U-238 alpha decay (fig. 5). No significant losses from a system are expected to occur between U-238 and Th-234; therefore, activities of U-238 estimated from total U concentration and activities of Th-234 should be equal. Comparison of Ra-226 and Th-234 activities should indicate if Ra-226 or intermediate U-234 has been lost from the rock. The first radionuclide in the Th-232 decay series measured by gamma-ray spectrometry is actinium-228 (Ac-228), the product of Ra-228 beta decay (fig. 5). The activity of Ac-228, the short-lived daughter of Ra-228, is a good estimator of Ra-228 activity. Comparison of Ac-228 and Th-232 activity estimated from total Th concentration may indicate whether or not Ra-228 has been lost from the rock.

A total of 17 well-cutting samples from 10 wells were analyzed by gainma-ray spectrometry (table 10) to determine the activity of some members of the U-238 and Th-232 decay series. K-40 activity is also reported and contributes to the total gamma activity meastred by geophysical logging. Total $U$ and Th concentrations were determined by neutron activation analysis for all 17 samples (table 10). For some of the samples, estimates for U-238 and Th-232 activities from total $U$ and $T$. concentrations are lower than those extrapolated from Th-234 and Ac-228 activities determined kv gamma-ray spectrometry. Uncertaintios and bias of each method and underlying assumptions are beyond the scope of this report.

Table 10. Solid-phase activities of uranium-238 and thorium-232 series radionuclides and potassium- 40 determined by gamma-ray spectrometry of well-cutting samples from the Chickies Quartzite

[pCi/g, picocuries per gram; <, less than]

\begin{tabular}{|c|c|c|c|c|c|c|c|c|c|c|c|}
\hline \multirow{2}{*}{$\begin{array}{c}\text { Well } \\
\text { number }\end{array}$} & \multirow{2}{*}{$\begin{array}{c}\text { Depth of } \\
\text { sample } \\
\text { (feet) }\end{array}$} & \multicolumn{5}{|c|}{ U-238 series } & \multicolumn{4}{|c|}{ Th-232 series } & \multirow{2}{*}{$K-40$} \\
\hline & & U-238 ${ }^{1}$ & Th-234 & Ra-226 & $\mathrm{Pb}-214$ & $\mathrm{Bi}-214$ & Th-232 ${ }^{1}$ & Ac-228 & $\mathrm{Pb}-212$ & Tl-208 & \\
\hline CH-3122 & 175 & 1.7 & 3.0 & 2.4 & 1.6 & 1.4 & 3.4 & 3.8 & 3.4 & 3.3 & 14 \\
\hline CH-3122 & 235 & .7 & $<1.0$ & 1.9 & .85 & .54 & .8 & 1.4 & 1.2 & .77 & 16 \\
\hline CH-3122 ${ }^{2}$ & 265 & .2 & $<.5$ & $<.7$ & .27 & .34 & .1 & $<.2$ & .65 & $<.1$ & 43 \\
\hline CH-3131 & 135 & 1.4 & $<2.0$ & 2.6 & 1.6 & 1.3 & 1.3 & 2.0 & 1.7 & 1.5 & 16 \\
\hline CH-3133 & 135 & 1.0 & $<1.0$ & $<2.0$ & 1.3 & .99 & 1.2 & 1.9 & 2.0 & 1.3 & 5.3 \\
\hline CH-3133 & $145-150$ & .8 & $<.9$ & $<1.0$ & .76 & .62 & .6 & .95 & .85 & .69 & 24 \\
\hline CH-3189 & 75 & 1.1 & $<2.0$ & $<2.0$ & .92 & 1.1 & 1.4 & 1.6 & 1.8 & 1.3 & 39 \\
\hline CH-3213 & $205-210$ & 1.1 & $<2.0$ & 2.2 & .94 & .8 & 1.4 & 1.9 & 1.7 & 1.5 & 49 \\
\hline CH-3213 & $210-215$ & 1.4 & 2.9 & 2.2 & 1.3 & 1.1 & 1.8 & 1.8 & 1.7 & 1.5 & 59 \\
\hline CH-3219 & $205-210$ & 1.1 & 2.0 & 2.0 & 1.5 & 1.1 & 1.4 & 2.6 & 1.7 & 1.6 & 82 \\
\hline CH-3219 & $295-300$ & .6 & $<2.0$ & $<2.0$ & 1.6 & 1.3 & 1.1 & 2.5 & 1.7 & 2.0 & 93 \\
\hline CH-3315 & 170 & 1.3 & 1.6 & 2.1 & 1.3 & 1.1 & 1.7 & 2.1 & 2.1 & 1.7 & 73 \\
\hline YO-1169 & $70-75$ & 1.9 & 2.9 & 2.7 & 1.7 & 1.4 & 3.4 & 3.6 & 3.1 & 3.1 & 32 \\
\hline YO-1171 & 125 & 1.5 & 1.7 & 2.7 & 1.4 & 1.3 & 2.2 & 2.7 & 2.7 & 2.4 & 32 \\
\hline YO-1172 & $130-135$ & .9 & $<.9$ & 1.6 & .89 & .64 & 2.2 & 2.4 & 2.2 & 2.2 & 23 \\
\hline YO-1172 & $200-205$ & .7 & $<.7$ & 1.3 & .75 & .65 & 1.1 & 1.4 & 1.3 & 1.2 & 14 \\
\hline YO-1172 & $210-215$ & .7 & $<.6$ & 1.2 & .62 & .52 & 1.1 & 1.3 & 1.0 & 1.0 & 14 \\
\hline
\end{tabular}

${ }^{1}$ U-238 and Th-232 activities calculated from mass of $U$ and Th (determined by neutron activation analysis) by use of tl ? approximation that $1 \mathrm{pCi} / \mathrm{g} \mathrm{U}-238=3 \mathrm{ppm} \mathrm{U}$ and $1 \mathrm{pCi} / \mathrm{g}$ Th-232 $=9 \mathrm{ppm}$ Th.

2 Mafic gneiss. 
Comparison of Ra-226 and Ac-228 activities with U-238 and Th-232 activities calculated from masses of $U$ and Th, respectively, and comparison of Ra-226 with Th-234 activities indicates n? apparent loss of $\mathrm{Ra}$ from the solid phase; however, differences in accuracy and magnitude of errors in analytical methods may not permit exact comparison by ratio of radionuclides in a series. Genorally, activities of $\mathrm{Pb}-214$ in the $\mathrm{U}-238$ series and $\mathrm{Pb}-212$ in the Th-232 series are less than activitier of $\mathrm{Rn}-226$ and $\mathrm{Ac}-228$, respectively. Both $\mathrm{Pb}-214$ and $\mathrm{Pb}-212$ occur after $\mathrm{Rn}-222$ and $\mathrm{Rn}-220$ in their respective series (fig. 5). The relatively low $\mathrm{Pb}-214$ and $\mathrm{Pb}-212$ activities may reflect loss of $\mathrm{Rn}$ gas from the solid phase.

The maximum K-40 activity was measured for well cuttings of light-colored quartzites (wells $\mathrm{CH}-3213, \mathrm{CH}-3219$, and $\mathrm{CH}-3315)$. The minimum $\mathrm{K}-40$ activity was measured in well cuttings of mafic gneiss (well CH-3122 at a depth of $265 \mathrm{ft}$ ) and conglomerates (wells CH-3122, CH-3131, $\mathrm{CH}-3133$, and YO-1172). Potassium feldspar is a possible source of $\mathrm{K}-40$ in the light-colored quartzites.

Six well-cutting samples were analyzed for Ra-226 and Ra-228 activities (table 11). The samples were from zones of high, moderate, and low gamma activity in three wells drilled within one half-mile of each other into the conglomerate and quartzite lithologies of the Chickies Quartzite. The Th and U concentrations in these six well-cutting samples also were determined by neutron activation analysis (table 8). One sample (CH-3133 at depth of $135 \mathrm{ft}$ ) was analyzed by gamma-ray spectrometry as well.

Activities of Ra-226 and Ra-228 are from 7 to nearly 100 percent less than those calculated for U-238 and Th-232 (table 11); these lower activities suggest that Ra-226 and Ra-228 may have been lost from the rock through natural processes. Although the mean percentage lost is about the seme for $\mathrm{Ra}-226$ and Ra-228, the proportion of Ra-226 lost is less variable than the proportion of Ra-228 lost from the rock samples; the variance of percentage of Ra-226 lost is significantly less than for F.a-228 as determined statistically by the nonparametric squared ranks test (Conover, 1980). The difference in the losses of Ra-226 and Ra-228 from the solid phase may reflect different mineral hosts or loss mechanisms for Th-232 and U-238 decay series radionuclides. Although the $\mathrm{Th} / \mathrm{U}$ mass ratios and approximately equivalent activity ratios of rock samples for the Chickies Quartzite are within the range of $<1.0$ to 14.2 (table 9 ) and $<0.3$ to 4.7 , respectively, observed activity ratios of the $T h$ and $U$ daughter products (Ra-228/Ra-226) in the aqueous phase may be different because leaching rates for the two $\mathrm{Ra}$ isotopes differ.

Table 11. Radium-226 and radium-228 activities, calculated uranium-238 and thorium-232 activities, and percent radium-226 and radium-228 loss for six well-cutting samples from the Chickies Quartzite

[pCi/g, picocuries per gram; --, no data]

\begin{tabular}{|c|c|c|c|c|c|c|c|c|c|}
\hline $\begin{array}{c}\text { Well } \\
\text { number }\end{array}$ & $\begin{array}{c}\text { Depth of } \\
\text { sample } \\
\text { (feet) }\end{array}$ & $\begin{array}{c}\text { U-238 } \\
{ }^{1}(\mathrm{pCi} / \mathrm{g})\end{array}$ & $\mathrm{Ra}-226$ & $\begin{array}{c}\text { Percent } \\
\text { Ra-226 } \\
\text { loss }\end{array}$ & $\begin{array}{l}\text { Th-232 } \\
\text { (pCi/g) }\end{array}$ & $\begin{array}{c}\text { Ra-228 } \\
\text { (pCi/g) }\end{array}$ & $\begin{array}{c}\text { Percent } \\
\text { Ra-228 } \\
\text { loss }\end{array}$ & $\begin{array}{l}\text { U-238/Th-232 } \\
\text { activity ratio }\end{array}$ & $\begin{array}{c}\text { Ra-228/Ra-226 } \\
\text { activity ratio }\end{array}$ \\
\hline $\mathrm{CH}-3122$ & 105 & 2.3 & 1.11 & 52 & 1.0 & 0.32 & 68 & 0.4 & 0.3 \\
\hline CH-3122 & 205 & 2.2 & 1.70 & 21 & 4.8 & 4.46 & 7 & 2.2 & 2.6 \\
\hline CH-3122 & 210 & 2.7 & 1.54 & 43 & 6.8 & 4.60 & 32 & 2.5 & 3.0 \\
\hline CH-3133 & 135 & 1.0 & .42 & 58 & 1.2 & 0 & 100 & -- & -- \\
\hline CH-3133 & 140 & .8 & .45 & 44 & .6 & .47 & 22 & .8 & 1.0 \\
\hline CH-3213 & $180-185$ & .8 & .44 & 45 & .9 & .42 & 53 & 1.1 & 1.0 \\
\hline
\end{tabular}

${ }^{1}$ U-238 and Th-232 activities calculated from mass of $U$ and Th (determined by neutron activation analysis) by use of the approximation that $1 \mathrm{pCi} / \mathrm{g}$ U-238 $=3 \mathrm{ppm} \mathrm{U}$ and $1 \mathrm{pCi} / \mathrm{g}$ Th-232 $=9 \mathrm{ppm}$ Th. 


\section{Radioactive Minerals}

U- and Th-bearing heavy minerals, such as zircon and monazite, in the Chickies Quartzite are potential sources of $\mathrm{Ra}$ and $\mathrm{Rn}$ in the ground water. Generally, zircon can contain up to 13.1 percent Th and 2.7 percent $U$, and monazite can contain up to 26.5 percent Th and 0.1 percent $U$ (Frondel and others, 1967; Durrance, 1986). Other possible sources are secondary minerals that may be the product of primary mineral weathering or such minerals as iron or other metal oxides that adsorb or incorporate $\mathrm{U}$, $\mathrm{Th}$, or $\mathrm{Ra}$.

Heavy-mineral separations of well cuttings from wells YO-1172, CH-3122, and LN-1715 yielded magnetite, zircon, rutile, monazite, titanite, iron oxides, and some unidentified minerals. Zircon crystals with dark, metamict cores (fig. 12) were identified in well cuttings from well CH-3122 (Gil Wizwall, West Chester University, oral commun.). Metamict cores are indications of radiation damage from $U$ or Th decay in the crystal lattice.

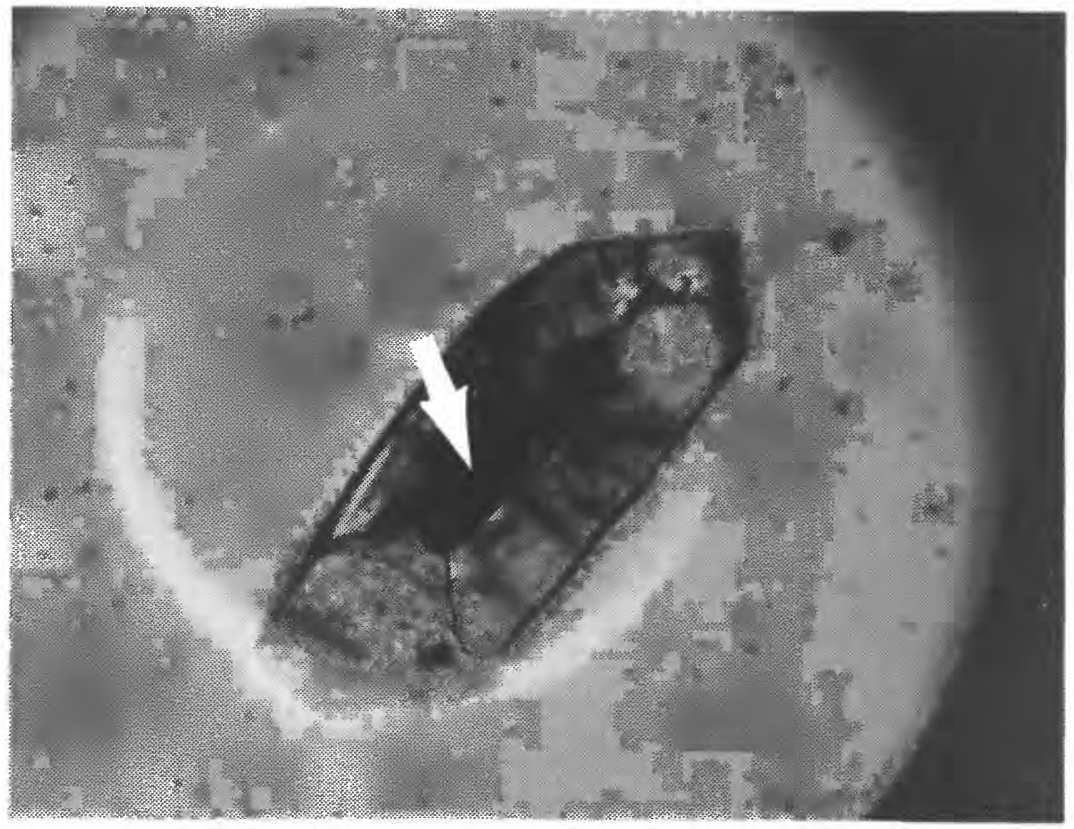

Figure 12. Photomicrograph of zircon with metamict core from well $\mathrm{CH}-3122$ cuttings. Reflected light $10 \times$ magnification. Photograph by David A. Sinson of West Chester University.

Radioactive minerals emit radiation that exposes photographic film, and a "picture" of the radioactivity, or autoradiograph, can be used to locate sources of radioactivity in a rock sample or thin section. Autoradiographs of a few thin sections of mounted heavy mineral separates and well cuttings were prepared by Linda C. Gunderson of the USGS. Point sources of radiation were found on the thin sections, indicating radioactivity was contained in and on edges of minerals and not disseminated in the matrix. The autoradiograph of well cuttings and heavy minerals from well CH-3122 shows that the heavy minerals are radioactive and that some radioactivity is associated with opaque minerals that surround larger mineral grains (fig. 13). The radioactivity at the edges of mineral grains could be from $\mathrm{U}, \mathrm{Th}$, or Ra in secondary minerals, such as iron oxides, that accumulate during weathering processes.

These heavy resistate minerals in the Chickies Quartzite are from Precambrian rocks that also probably were sources for the zircons in other rocks in southeastern Pennsylvania. Detrital zircons in the Devonian Catskill Formation in east-central Pennsylvania are reported to contain up to about 0.17 percent Th and 1.2 percent $U$ (Tole, 1979). 

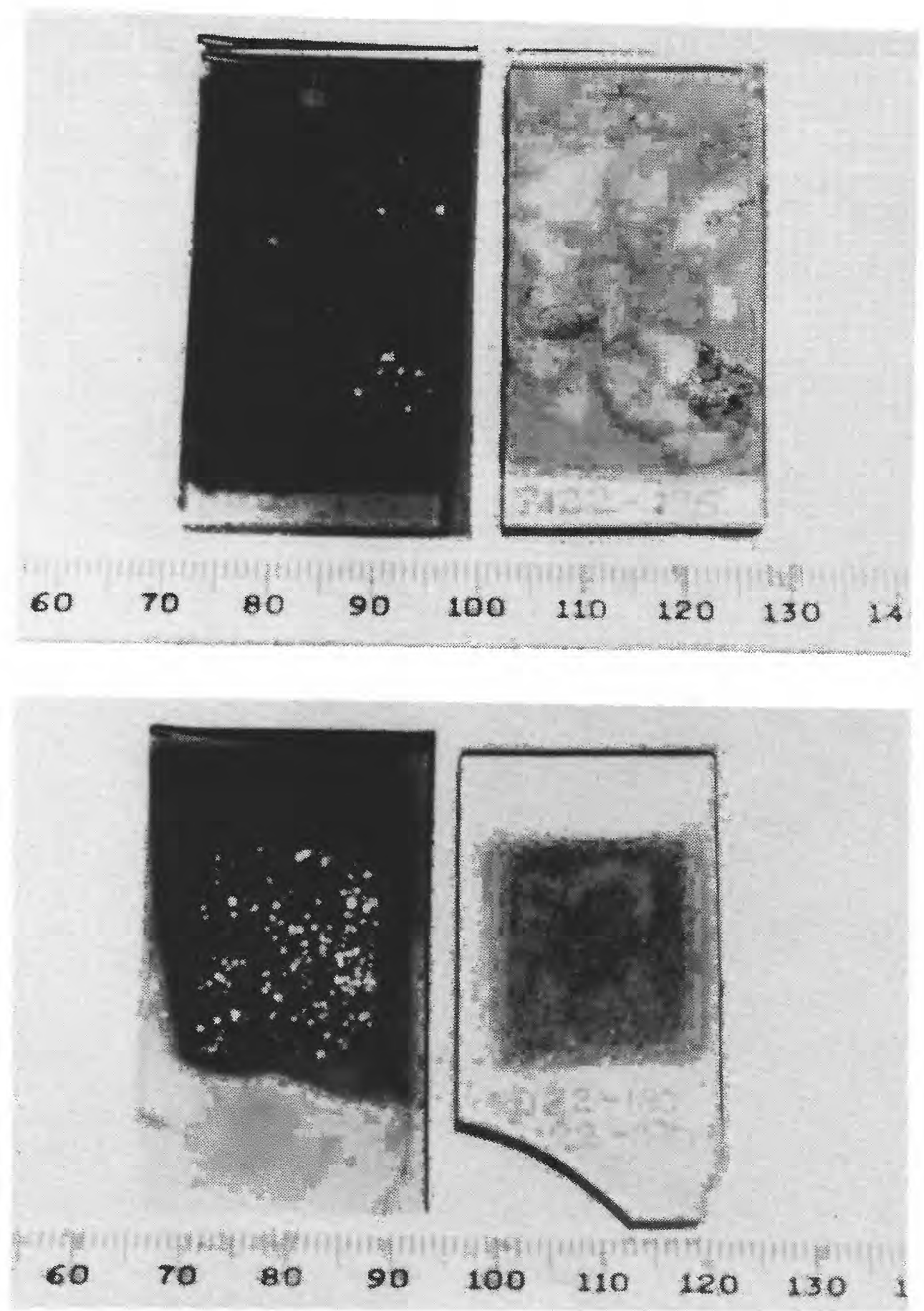

Figure 13. Autoradiographs (left) and thin sections (right) of heavy-mineral separates from well $\mathrm{CH}-3122$ cuttings. Light areas of autoradiographs indicate radioactivity. Minerals are from well cuttings from (a) 175 feet and (b) 180 feet below land surface. Scale is in centimeters. Photographs by Linda C. Gunderson, U.S. Geological Survey. 


\section{Distribution of Radium and Radon in Ground Water}

The range and median of Ra-226, Ra-228, combined Ra-226 and Ra-228, and Rn-222 activities, gross alpha- and gross beta-particle activity, Ra-228/Ra-226 activity ratios, and $\mathrm{U}$ concentrations in ground water from 160 wells penetrating the Chickies Quartzite are listed in table 12 . Activities cf Ra-226, Ra-228, and Rn-222 range over two orders of magnitude. Ra-228 activity exceeds Ra-226 activity in about 92 percent of the water samples from the Chickies Quartzite. The median Ra-22 $\AA^{\prime}$ Ra-226 activity ratio of 2.4 in ground water in the Chickies Quartzite is greater than the ratio of J.1 for mean crustal abundance of $U$ and $T h$ (table 7).

Cumulative frequency distributions of Ra-226, Ra-228, and Rn-222 (figs. 14 and 15) are useful for estimating the likelihood of observing activities of a given magnitude of these radionuclides in ground water in the Chickies Quartzite. Forty-seven percent of the 160 samples contained combined Ra-226 and Ra-228 activities greater than $5 \mathrm{pCi} / \mathrm{L}$, the USEPA MCL for Ra in drinking water.

Table 12. Range and median values of radiochemical constituents for water samples from 160 wells in the Chickies Quartzite

[pCi/L, picocuries per liter; $\mu \mathrm{g} / \mathrm{L}$, micrograms per liter; alpha, gross alpha-particle activity; beta, gross beta-particle activity; $<$, less than]

\begin{tabular}{lcrrr}
\hline \multicolumn{1}{c}{ Constituent or property } & $\begin{array}{c}\text { Number of } \\
\text { samples }\end{array}$ & \multicolumn{2}{c}{ Range } & Median \\
\hline Radiochemical consitituents & & & & \\
Ra-226 (pCi/L) & 160 & $<0.1-$ & 41 & 1.2 \\
Ra-228 (pCi/L) & 160 & $<1.0-160$ & 2.6 \\
Alpha (pCi/L as U-nat) & 160 & $<.1-171$ & 4.5 \\
Beta (pCi/L as Cs-137) & 160 & $1.0-230$ & 7.0 \\
Rn-222 (pCi/L) & 160 & $114-32,300$ & 2,400 \\
U ( $\mu$ g/L) & 160 & $<.05-\quad 6.6$ & .09 \\
Calculated values & & & & \\
Ra-226 + Ra-228 (pCi/L) & 160 & $<1.2-\quad 172$ & 4.2 \\
Ra-228/Ra-226 ${ }^{1}$ & 100 & $.37-$ & 30 & 2.4 \\
\hline
\end{tabular}

${ }^{1}$ Activity ratio calculated only where both $\mathrm{Ra}-226$ and $\mathrm{Ra}-228$ activities are above lowest reporting level. 

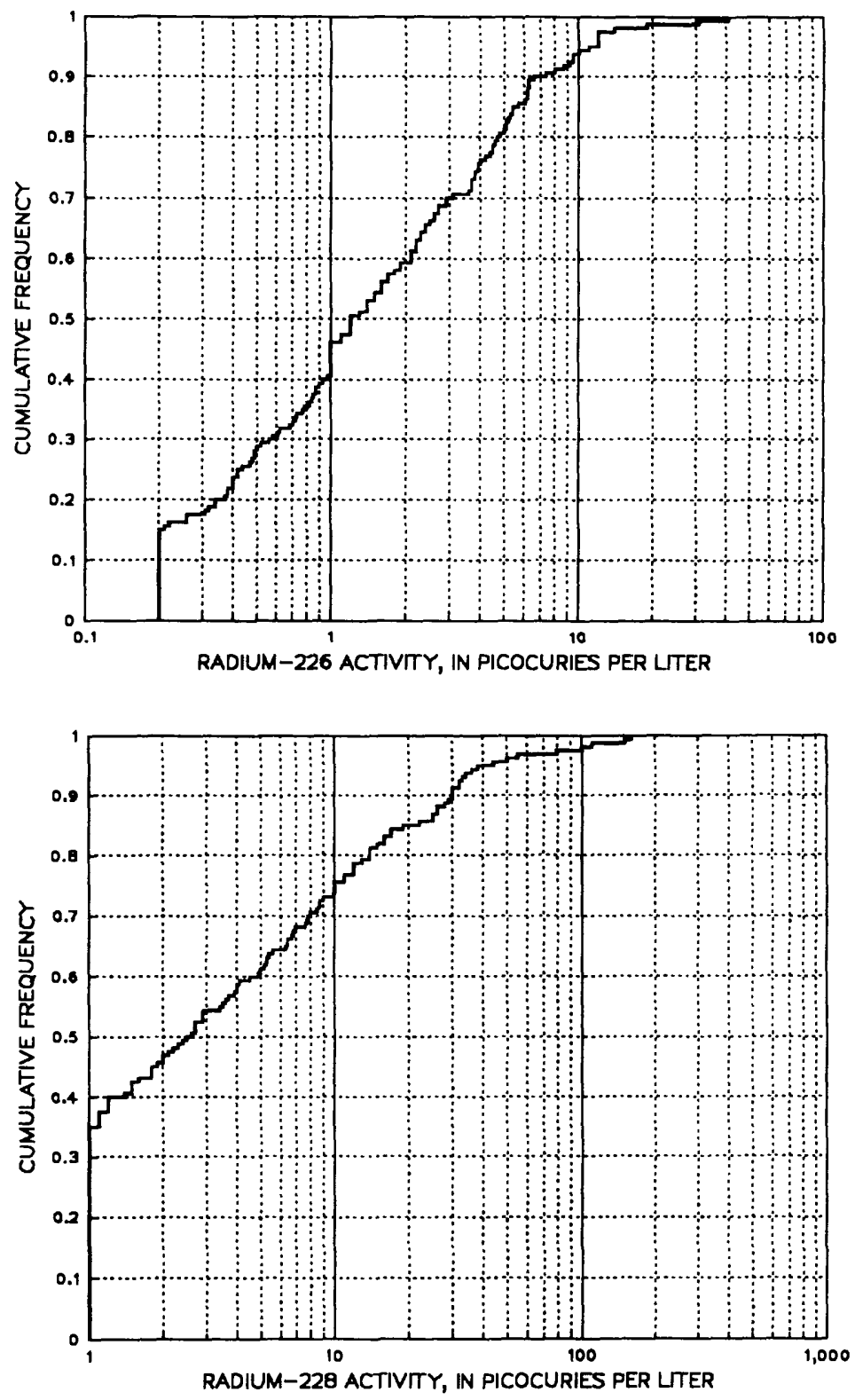

Figure 14. Cumulative frequency of radium-226 and radium-228 activities in ground water in the Chickies Quartzite. Total number of samples is 160 . 

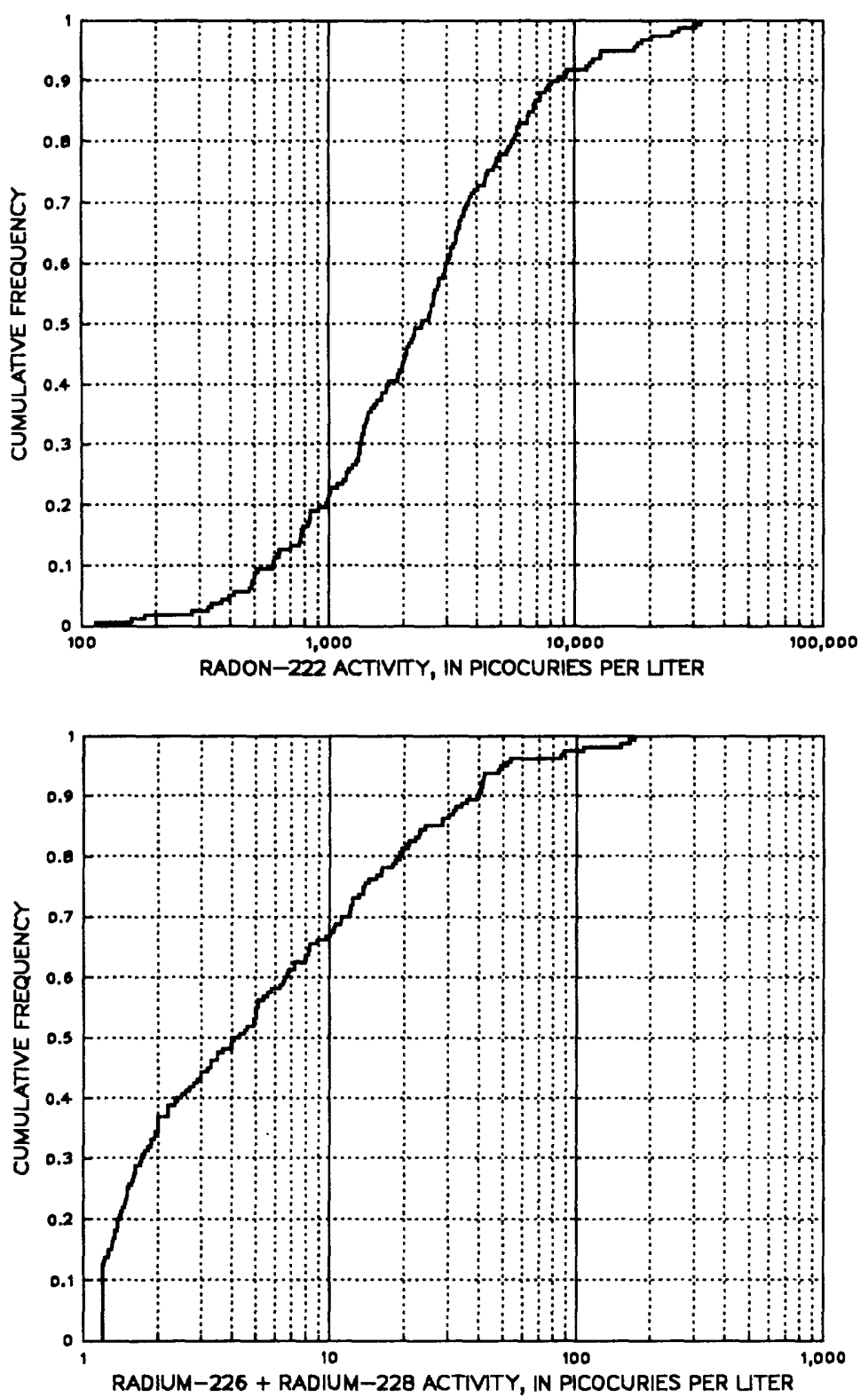

Figure 15. Cumulative frequency of radon-222 and the sum of radium-226 and radium-228 activities in ground water in the Chickies Quartzite. Total number of samples is 158 for radon-222 and 160 for radium-226 + radium-228. 


\section{Spatial Distribution}

$\mathrm{Ra}$ and $\mathrm{Rn}$ activities in ground water are not evenly distributed over the area of outcrop of the Chickies Quartzite, although elevated Ra activities were measured in ground water throughout the entire area. Spatial distributions of $\mathrm{Ra}$ and $\mathrm{Rn}$ in ground water are controlled by geologic and hydrologic factors that may cause regional patterns. The geographic distribution of $\mathrm{Ra}$ and $\mathrm{Rn}$ activity in ground water from sampled wells penetrating the Chickies Quartzite, grouped into the eastern, central, and western areas, is given in table 13 and shown in boxplots in figures 16 and 17. The distribution of $\mathrm{Ra}$ and $\mathrm{Rn}$ activity by county is given in table 14 .

Ground-water samples from the central area of the Chickies Quartzite have the greatest median activities of Ra-226, Ra-228, combined Ra-226 and Ra-228, and Rn-222 and the greatest percentage of combined Ra-226 and Ra-228 activities that exceed $5 \mathrm{pCi} / \mathrm{L}$ (table 13). Ground water in both the eastern and western areas had similar median activities that are lower than the median activities in the central area for Ra-226, Ra-228, and combined Ra-226 and Ra-228. Ground-wnter samples from the western and central areas have a greater median Rn-222 activity than those of the eastern area. The median Ra-228/Ra-226 activity ratios are greater in the eastern and central areas than those in the western area and are especially high in Chester County.

$\mathrm{Ra}$ activities exceeding $5 \mathrm{pCi} / \mathrm{L}$ were detected in ground-water samples from the ChickieQuartzite in York, Lancaster, Chester, and Bucks Counties (table 14). Elevated Ra activities wore not detected in ground-water samples from Montgomery and Berks Counties; however, this may b? the result of the small number of samples collected in these counties. The maximum median activities for Ra-226, Ra-228 and combined Ra-226 and Ra-228 are in ground water in Chester and Lancaster Counties. Ground water in Berks, Bucks, Montgomery, and York Counties have similar median activities that are less than the median activities of ground water in Chester and Lancaster Counties for Ra-226, and Ra-228, and combined Ra-226 and Ra-228. Median Rn-222 activities are greatest in ground water in Chester, Lancaster, and York Counties. 
Table 13. Distribution of radium and radon-222 activities in ground water of the Chickies Quartzite by geographic area

$[<$, less than; pCi/L, picocuries per liter]

\begin{tabular}{|c|c|c|c|}
\hline & \multicolumn{3}{|c|}{ Area } \\
\hline & East & Central & West \\
\hline \multicolumn{4}{|c|}{ Sum of Ra-226 and Ra-228 activities } \\
\hline Number of samples & 9 & 113 & 38 \\
\hline Minimum (pCi/L) & $<1.2$ & $<1.2$ & $<1.2$ \\
\hline Maximum $(\mathrm{pCi} / \mathrm{L})$ & 54 & 172 & 42 \\
\hline Median (pCi/L) & 1.4 & 6.5 & 1.6 \\
\hline \multicolumn{4}{|c|}{$\begin{array}{l}\text { Sum of Ra-226 and Ra-228 activities } \\
\text { exceeding } 5 \mathrm{pC} \text { C } / \mathrm{L}\end{array}$} \\
\hline Number of samples & 2 & 65 & 8 \\
\hline Percent of samples in area & 22 & 58 & 21 \\
\hline \multicolumn{4}{|l|}{ Ra-226 activitiy } \\
\hline Number of samples & 9 & 113 & 38 \\
\hline Minimum (pCi/L) & $<.1$ & $<.2$ & $<.2$ \\
\hline Maximum $(\mathrm{pCi} / \mathrm{L})$ & 3.8 & 41 & 12 \\
\hline Median (pCi/L) & .4 & 2.1 & .5 \\
\hline \multicolumn{4}{|l|}{ Ra-228 activity } \\
\hline Number of samples & 9 & 113 & 38 \\
\hline Minimum $(\mathrm{pCi} / \mathrm{L})$ & $<1.0$ & $<1.0$ & $<1.0$ \\
\hline Maximum $(\mathrm{pCi} / \mathrm{L})$ & 50 & 160 & 30 \\
\hline Median (pCi/L) & $<1.0$ & 4.0 & $<1.0$ \\
\hline \multicolumn{4}{|l|}{ Ra-228/Ra-226 activity ratio } \\
\hline Number of samples & 3 & 84 & 13 \\
\hline Minimum & 1.9 & .6 & .9 \\
\hline Maximum & 13 & 30 & 9 \\
\hline Median & 2.8 & 2.7 & 1.7 \\
\hline \multicolumn{4}{|l|}{ Rn-222 activity } \\
\hline Number of samples & 9 & 111 & 38 \\
\hline Minimum (pCi/L) & 160 & 110 & 180 \\
\hline Maximum (pCi/L) & 3,500 & 32,300 & 20,300 \\
\hline Median (pCi/L) & 1,600 & 2,600 & 2,300 \\
\hline
\end{tabular}



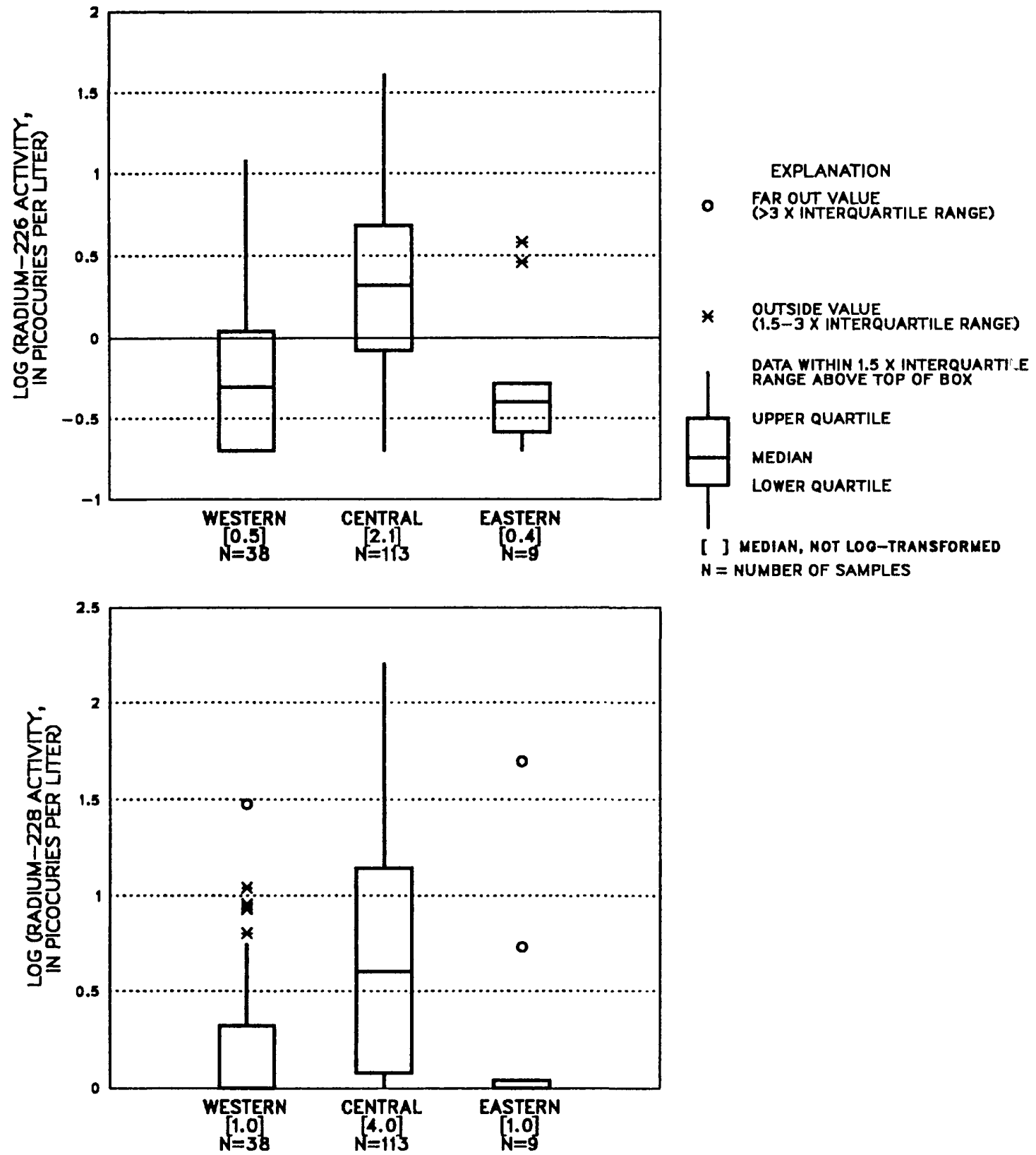

Figure 16. Distribution of radium-226 and radium-228 in ground water from the eastern, central, and western areas of outcrop of the Chickies Quartzite. Lower limit of detection is 0.2 picocuries per liter for radium-226 and 1.0 picocuries for radium-228. 

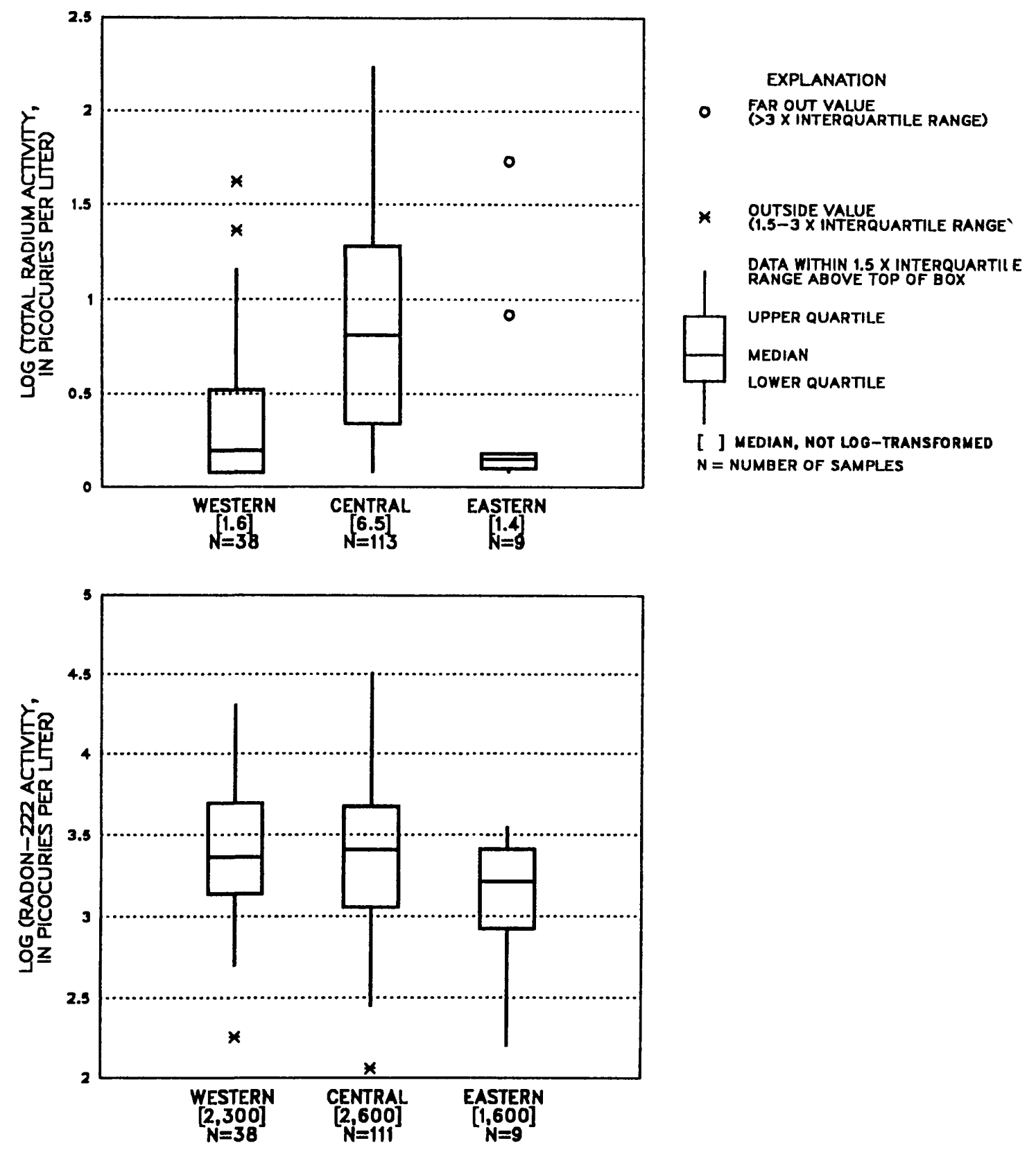

Figure 17. Distribution of radon-222 and the sum of radium-226 and radium-228 in ground water from the eastern, central, and western areas of outcrop of the Chickies Quartzite. Lower limit of detection is 1.2 picocuries per liter for radium-226 + radium-228. 
Table 14. Distribution of radium and radon-222 activities in ground water of the Chickies Quartzite by county $[--$, no data; <, less than; pCi/L, picocuries per liter]

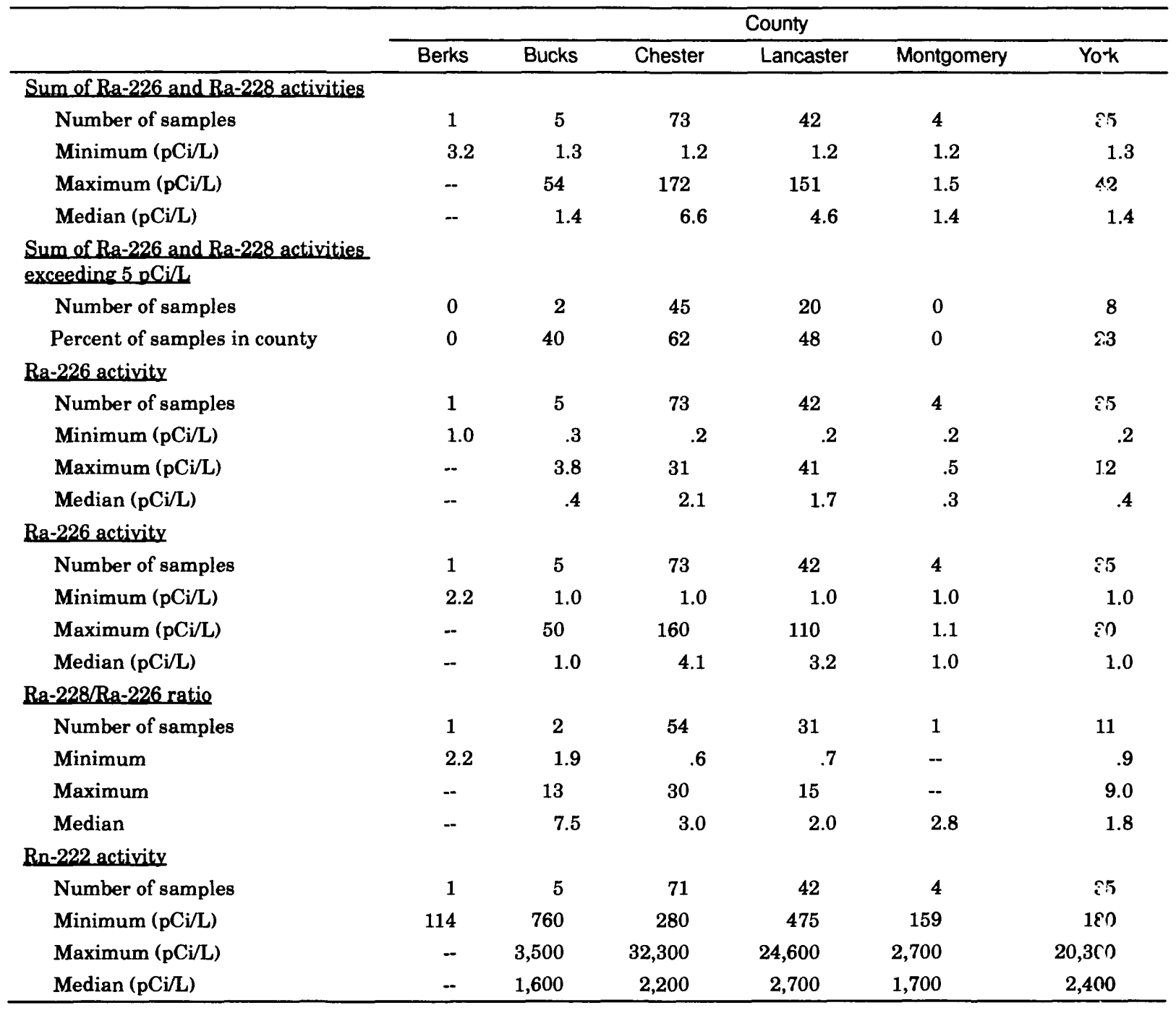




\section{Factors affecting spatial distribution}

The distribution of $\mathrm{Ra}-226, \mathrm{Ra}-228$, and $\mathrm{Rn}-222$ activities in ground water of the Chickies Quartzite was examined by use of nonparametric statistics with respect to lithology, ground-water chemistry, aquifer and well-construction characteristics, and topographic setting. Statistically significant correlations between $\mathrm{Ra}, \mathrm{Rn}-222$, and physical and chemical factors are discussed and related to the hydrogeologic setting. The differences in distribution of $\mathrm{Ra}$ and $\mathrm{Rn}$ activities reflec ${ }^{+}$. differences in rock composition, including variable $T h$ and $U$ distributions indicative of different source areas and depositional environments. Reactions with other chemical constituents along ground-water flow paths also affect the distribution of $\mathrm{Ra}$ and $\mathrm{Rn}$ activities in the ground water.

Lithology,--The nonparametric Kruskal-Wallis one-way analysis of variance (ANOVA) w:th rank transformed data was used to determine whether the mean rank of $\mathrm{Rn}-222, \mathrm{Ra}-226$, and $\mathrm{Ra}-228$ activities in ground water in the three mapped lithologies (conglomerate, quartzite, and slate) are significantly different at the 95-percent-confidence interval. If any difference was significant, a nonparametric multiple comparison test (MCT) was used to determine which lithologic-group mean rank was different. Corrections for tied ranks in this test were made (Conover, 1980, p. 230). Differences in mean ranks for the slate should be interpreted with caution because the small sarnple size may not accurately represent that lithology.

The Kruskal-Wallis test for Ra-226, Ra-228, and Rn-222 was significant at the 95-percent confidence level ( $p$-values $<0.05$ ), indicating that the mean rank of activities was not the same for all of the lithologies. The MCT was then performed on subsets to determine which lithologies were different. For Ra-226, the Kruskal-Wallis p-value was 0.002 for all three lithologies. The MCT test showed that the mean ranks for the quartzite and the conglomerate ( $p$-value $=0.67$ ) were the same, and the mean ranks for the quartzite and slate were different ( $\mathrm{p}$-value $=0.001$ ). For $\mathrm{Ra}-228$, the Kruskal-Wallis p-value was 0.002 for all three lithologies. The MCT showed that the mean ranks for quartzite and conglomerate were the same $(p-v a l u e=0.64)$, and the mean ranks for the quartzite and slate were different $(p$-value $=0.001$ ). For $R n-222$, the Kruskal-Wallis $p$-value was 0.005 for all tl ree lithologies. The MCT test showed that the mean ranks for the quartzite and slate were the same ( $p$-value $=0.50$ ), and the mean ranks for the quartzite and conglomerate were different ( $\mathrm{p}$-value = 0.003 ). Thus, the mean rank of Ra-226 and Ra-228 activity in ground water is greater for the conglomerate and quartzite than for the slate, and the mean rank of $\mathrm{Rn}-222$ activity in ground water is greater for the conglomerate than for the quartzite and slate. Median ground-water Ra-226 and Ra-228 activities increase from the slate (median is less than level of detection) to the conglomerate and quartzite (fig. 18). Median ground-water Rn-222 activity increases from the slate to the quartzite to the conglomerate (fig. 18).

Differences in $\mathrm{Ra}$ and $\mathrm{Rn}-222$ activities in ground water (fig. 18) in the three lithologies could be explained by differences in $\mathrm{U}, \mathrm{Th}$, and $\mathrm{Ra}$ concentrations and (or) mode of occurrence in the aquifer material. Loomis (1987, p. 33) found that the average Rn concentration in ground water in the Piedmont of North Carolina was consistent with the relative abundance of $U$ in rocks, and that aquifer lithology was a useful predictor of $R n$ concentration in ground water. The relative magnitıdes of median Rn-222 activity in ground water from the three lithologies suggest that the $U$ concentrat in is progressively greater from the slate to the quartzite to the conglomerate. However, the limited number of rock analyses (tables 8 and 9) do not indicate mode difference in $U$ concentrations in the three lithologies. Distribution of Rn-222's parent, Ra-226, within the aquifer is controlled by the presence of parent $U$-bearing minerals and of Ra-bearing minerals in the aquifer; $U$ and $R a$ can $\mathrm{I}$ ? adsorbed on edges of mineral (clays and Fe and Mn oxides) or incorporated into the crystal structure of a mineral $U$ (in zircon) or $\operatorname{Ra}$ (in barite). 


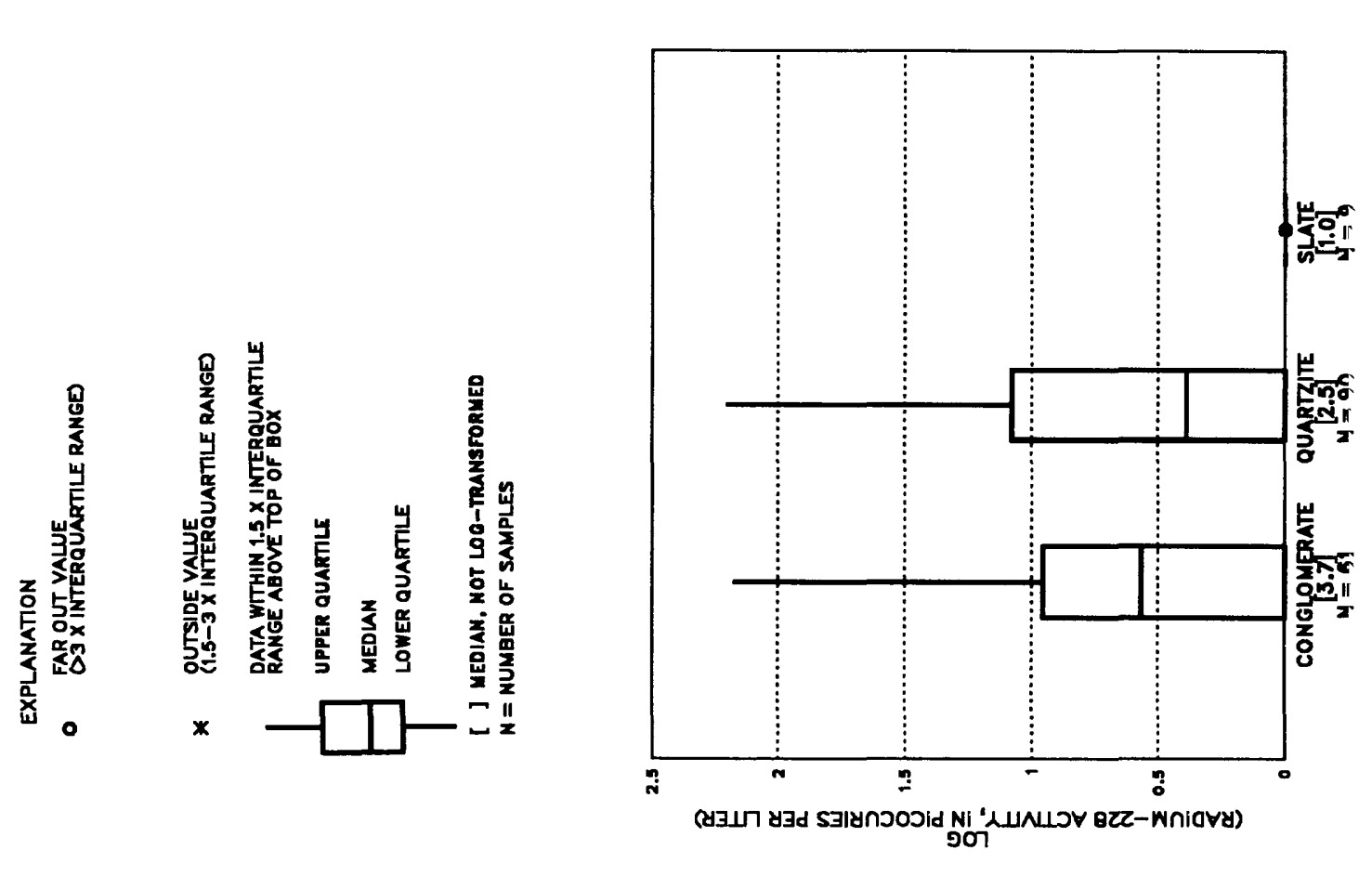

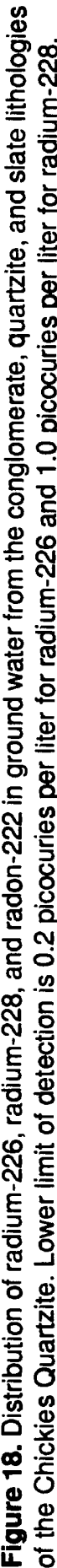
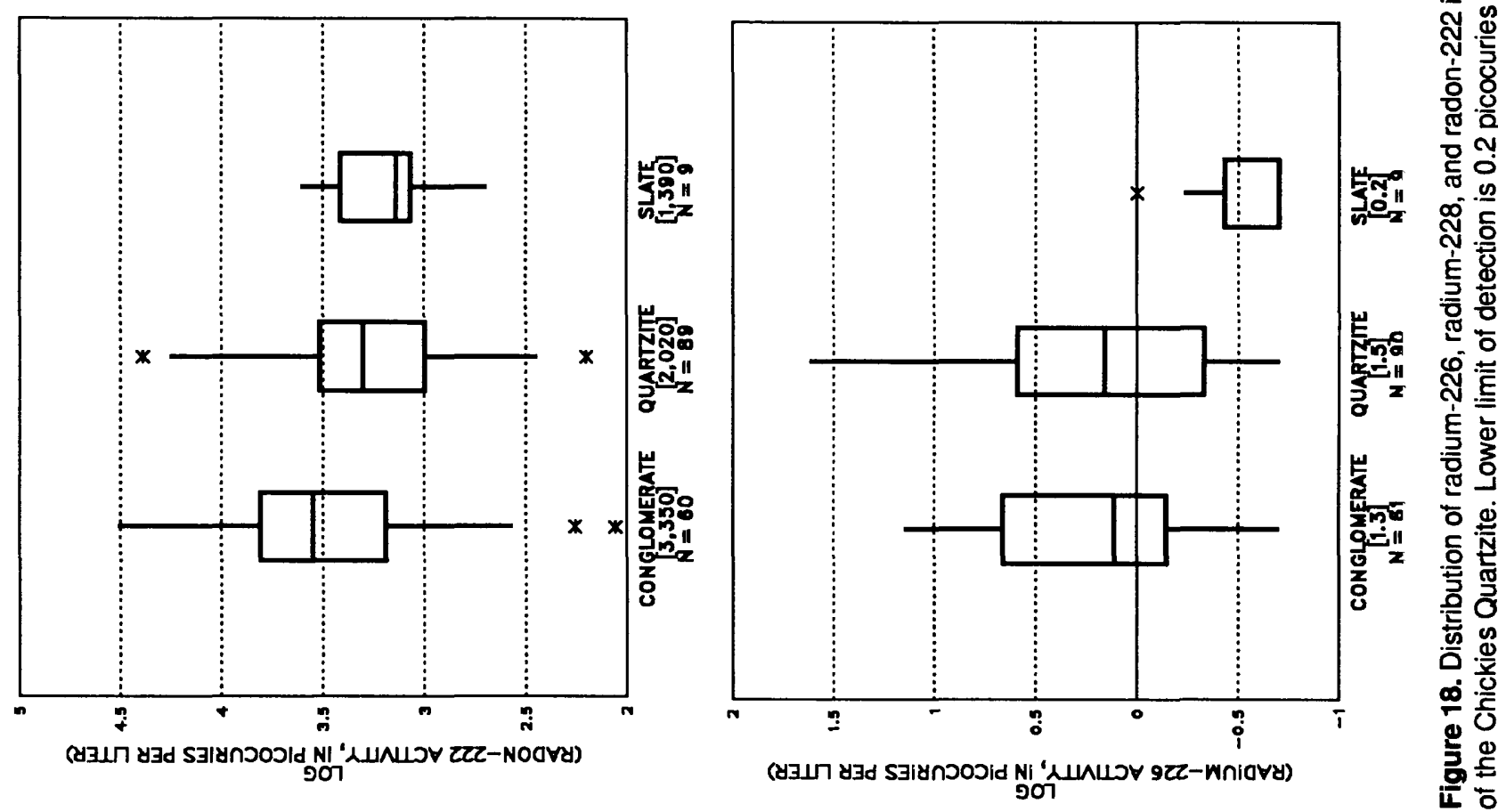
Chemistry of ground water,--Differences in Ra-226 and Ra-228 activities in ground wster of the Chickies Quartzite are related to ground-water chemistry and to the U and Th content of tro rocks. The general chemical character of ground water associated with elevated $\mathrm{Ra}$ activities is displayed on piper diagrams showing relative concentrations of major cations and anions in milliequivalent percents for ground-water samples that contain total Ra activities greater than or equal to $5 \mathrm{pCi} / \mathrm{L}$ and less than $5 \mathrm{pCi} / \mathrm{L}$ (fig. 19). A comparison of the piper diagrams (fig. 19) indica te that elevated $\mathrm{Ra}$ activities are associated with relatively greater concentrations of $\mathrm{Na}, \mathrm{K}, \mathrm{SO}_{4}, \mathrm{Mg}^{\text {, }}$, and $\mathrm{Cl}+\mathrm{NO}_{3}$, and relatively lower concentrations of $\mathrm{Ca}$ and $\mathrm{HCO}_{3}$.

Statistically significant correlations between chemical constituents and the activities of Ra-226, Ra-228, and Rn-222 in the ground water were determined by use of Spearman's rho rank correlat:on test. Because the MCT analyses indicate that the conglomerate and quartzite contain ground water with activities of $\mathrm{Ra}$ different from ground water in the slate, correlations for $\mathrm{Ra}$ isotopes included only the data from ground water in the conglomerate and quartzite, which are assumed to be representative of a single population. Results of the two-tailed Spearman's rho correlation test at the 95-percent-confidence interval are given in table 15.

The correlations indicate that elevated Ra-226 and Ra-228 activities are strongly inversely related to $\mathrm{pH}$, alkalinity, and $\mathrm{SiO}_{2}$ concentration, and strongly positively related to $\mathrm{DOC}, \mathrm{Ba}, \mathrm{SO}_{4}, \mathrm{Mn}$ concentrations and specific conductance. Weak, but significant, positive correlations were noted between $\mathrm{Ra}$ and $\mathrm{Cl}, \mathrm{NO}_{3}, \mathrm{Na}, \mathrm{Mg}, \mathrm{K}, \mathrm{U}$, and TDS concentrations. Both Ra-226 and Ra-228 correlate with the same constituents and properties, and, therefore, correlations are discussed for $\mathrm{Ra}$ in general, unless otherwise specified. Ra-226 and Ra-228 activities also strongly correlate with each other; each isotope has the identical chemical properties of $\mathrm{Ra}$. Because of variable $\mathrm{Ra}-228 / \mathrm{Ra}-22 \epsilon$ activity ratios related to variable distribution of $T h$ and $U$ in the aquifer, the $r_{s}$ measuring correlation between Ra-226 and Ra-228 is less than 1.0.

Alpha-particle activity correlates more strongly with Ra-226 than Ra-228 activity, and betaparticle activity correlates more strongly with Ra-228 activity than Ra-226 activity. The magnitude and order of the alpha- and beta-particle correlations with Ra-226 and Ra-228 is expected because. $\mathrm{Ra}-226$ is an alpha-particle emitter and Ra-228 is a beta-particle emitter. Alpha-particle and betaparticle activities are good predictors of Ra-226 and Ra-228 activities, respectively.

Ra-226 of the U-238 decay chain and Ra-228 of the Th-232 decay chain correlates positively, but weakly, with U. Ra-226 and parents, U-238 and U-234, may enter ground water from the same source area in the aquifer but be separated in the aqueous phase because of differences in chemical behavior between $\mathrm{Ra}$ and $\mathrm{U}$. $U$, unlike $\mathrm{Ra}$, correlates positively with $\mathrm{Ca}$ and alkalinity $\left(r_{s}=0.38\right.$ and 0.22 , respectively). $\mathrm{U}$ commonly forms anion complexes, especially in oxidizing solutions, whereas $\mathbf{R a}$ commonly exists as a free cation (Riese, 1982). $U$ forms carbonate complexes, and U mobility is enhanced in the presence of $\mathrm{HCO}_{3}$ (Chatham and others, 1981) in neutral or alkaline waters, wherizas $\mathrm{Ra}$ is most mobile in acidic waters. Sorption of $\mathrm{U}$ onto Fe-oxides is greatest at pH near 5 (Ames and others, 1983), which is close to the median $\mathrm{pH}$ for ground water from the quartzite and conglomerate.

Ra-226 does not appear to be in secular equilibrium with its parent U-234. For two samples with sufficient concentrations of $U$ for detection of isotopic $U, U-234$ and U-238 analyses were performed. $U$ isotopic disequilibrium in water caused by fractionation between solid and aqueous phases can occur by a number of mechanisms, including alpha recoil (Osmond and Lowart, 1976). Water from well YO-1179 contained $12 \mathrm{pCi} / \mathrm{L}$ Ra-226 and $0.67 \mu \mathrm{g} / \mathrm{L} \mathrm{U}$, comprised of $0.2 \mathrm{pCi} / \mathrm{L}$ each of U-238 and U-234. Water from well LN-1725 contained $41 \mathrm{pCi} / \mathrm{L} \mathrm{Ra-226}$ and $0.74 \mu \mathrm{g} / \mathrm{L} \mathrm{U}$, comprised of $0.2 \mathrm{pCi} / \mathrm{L} \mathrm{U}-238$ and $0.3 \mathrm{pCi} / \mathrm{L} \mathrm{U}-234$. In these two samples, activity of Ra-226 is two orders of magnitude greater than the activity of its parent in solution. Activities of relatively shorter-lived isotopes may increase in ground water more rapidly than longer-lived isotopes of the same decay series in aquifers where the radioactivity of the rock matrix is high, but the rock is resistant to solution (Durrance, 1986), such as the Chickies Quartzite. 
TOTAL RADIUM ACTIVITY

GREATER THAN OR EQUAL TO

5 PICOCURIES PER LITER

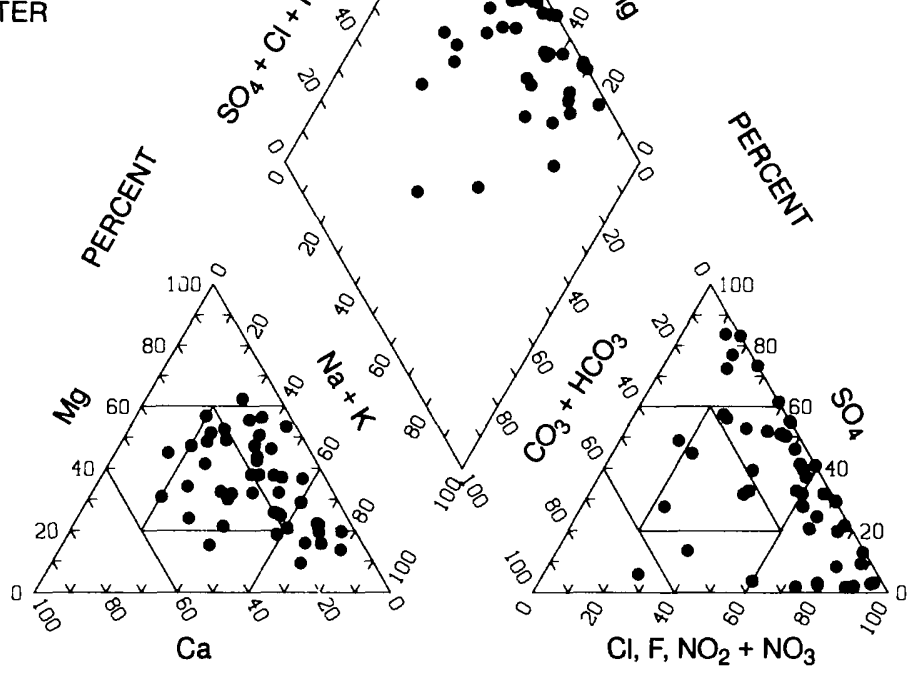

PERCENT

TOTAL RADIUM ACTIVITY LESS THAN 5 PICOCURIES

PER LITER

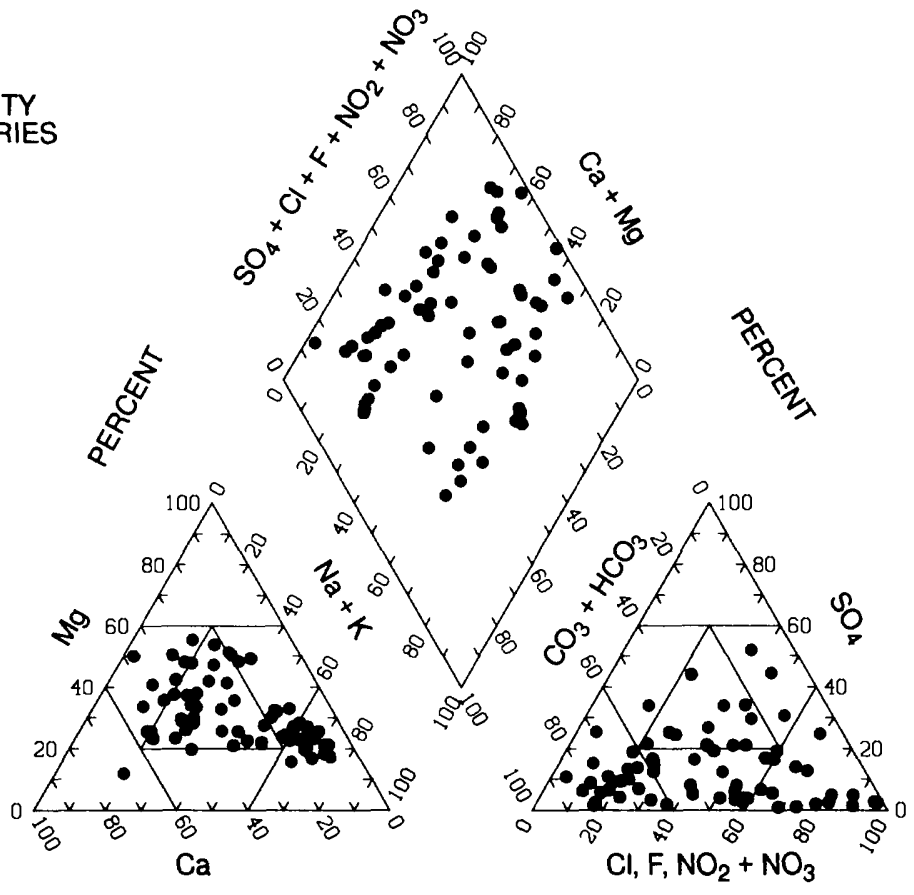

PERCENT

Figure 19. Piper diagrams comparing chemical character of ground water with and without elevated radium activities from wells in the Chickies Quartzite. Percentage of ions in milliequivalents. 
Table 15. Correlations among activities of radium-226 and radium-228 and chemical constituents and properties significant at the 95-percent confidence interval for ground-water samples from 160 wells in the Chickies Quartzite

[ $r_{s}$, Spearman rho correlation coefficient; alpha, gross alpha-particle activity; beta, gross beta-particle activity]

\begin{tabular}{|c|c|c|c|c|}
\hline \multicolumn{2}{|l|}{ Ra-226 } & \multicolumn{3}{|l|}{ Ra-228 } \\
\hline Chemical constituent or property & $r_{s}$ & Chemical constituent or property & $r$ & $r_{s}$ \\
\hline \multicolumn{5}{|l|}{$\begin{array}{l}\text { Correlation coefficient p-values } \\
\text { less than } 0.0001\end{array}$} \\
\hline Total $\mathbf{R a}^{1}$ & 0.93 & Total $\mathbf{R a} 1$ & $0.9^{\prime}$ & \\
\hline Alpha & .91 & Beta & .88 & \\
\hline Ra-228 & .85 & Alpha & $.8^{\prime}$ & \\
\hline Beta & .85 & Ra-226 & .8 & \\
\hline $\mathrm{pH}$ & -.68 & $\mathrm{pH}$ & $-.6^{\prime}$ & \\
\hline $\mathbf{B a}$ & .62 & DOC & $.6^{\prime}$ & \\
\hline DOC & .60 & $\mathrm{Ba}$ & .6 & \\
\hline Alkalinity & -.60 & Alkalinity & -.5 & \\
\hline $\mathrm{SiO}_{2}$ & -.51 & $\mathrm{SiO}_{2}$ & -.5 & \\
\hline $\mathbf{M n}$ & .49 & $\mathrm{SO}_{4}$ & .4 & \\
\hline $\mathrm{SO}_{4}$ & .37 & Mn & .4 & \\
\hline Specific conductance & .33 & Specific conductance & .3 & \\
\hline \multicolumn{5}{|c|}{$\begin{array}{l}\text { Correlation coefficient } p \text {-values greater than or } \\
\text { equal to } 0.0001 ; p \text {-value in parenthesis ( ) following } \\
\text { coefficient }\end{array}$} \\
\hline $\mathrm{PO}_{4}$ & $-0.41(.0019)$ & $\mathrm{PO}_{4}$ & -0.45 & $(.0005)$ \\
\hline $\mathrm{NO}_{3}$ & $.39(.0034)$ & $\mathrm{NO}_{3}$ & .30 & $(.0272)$ \\
\hline B & $.36(.0058)$ & B & .35 & $(.0075)$ \\
\hline $\mathrm{Cl}$ & $.29(.0003)$ & $\mathrm{Cl}$ & .29 & $(.0003)$ \\
\hline $\mathbf{F}$ & $.29(.0003)$ & $\mathbf{F}$ & .28 & $(.0004)$ \\
\hline TDS & $.26(.0006)$ & TDS & .28 & $(.0004)$ \\
\hline $\mathbf{M g}$ & $.26(.0013)$ & $\mathbf{M g}$ & .26 & $(.0014)$ \\
\hline $\mathbf{K}$ & $.24(.0030)$ & $\mathrm{Na}$ & .24 & (.0028) \\
\hline $\mathrm{Na}$ & $.23(.0040)$ & $\mathrm{U}$ & .20 & $(.0132)$ \\
\hline U & $.09(.0176)$ & $\mathbf{K}$ & .16 & $(.0497)$ \\
\hline
\end{tabular}

1 Total radium activity equals combined activities of radium-226 and radium-228.

Ra-226 does not correlate with its daughter, $R n-222$, in solution. Elevated $R n-222$ activity in ground water is expected where Ra-226 is concentrated in aquifer materials and not necessarily where Ra-226 is dissolved and, therefore, actively being leached from the aquifer materials. Ra-22 $\mathrm{S}$ is not in secular equilibrium in solution with daughter Rn-222. The activity of Ra-226 is as much as fivo orders of magnitude less than that of Rn-222 in ground water in the Chickies Quartzite.

The negative relation of $\mathrm{Ra}$ with $\mathrm{pH}$ (fig. 20) shows $\mathrm{pH}$ is a strong control on Ra activities. $f 11$ ground-water samples from the Chickies Quartzite with $\mathrm{pH}$ less than 4.7 have combined activitie ${ }^{-}$of Ra-226 and Ra-228 greater than $5 \mathrm{pCi} / \mathrm{L}$ (fig. 21). Low pH decreases adsorption of $\mathrm{Ra}$ and other cations onto $\mathrm{SiO}_{2}$, kaolinite (Riese, 1982), and other mineral surfaces, such as $\mathrm{Fe}$ and $\mathrm{Mn}$ hydroxides. 

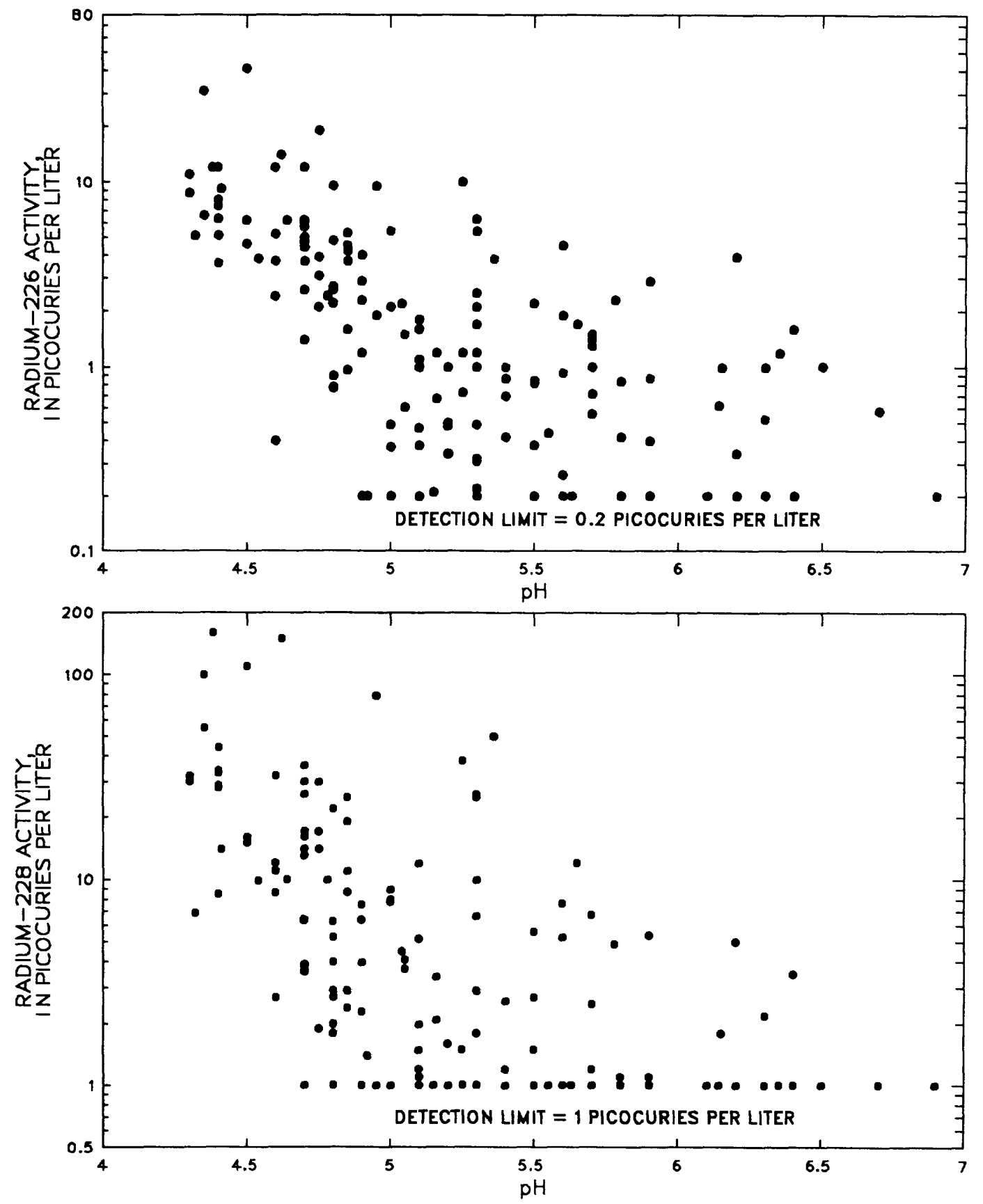

Figure 20. Relation between $\mathrm{pH}$ and radium-226 and radium-228 for ground water from the quartzite and conglomerate lithologies of the Chickies Quartzite. [pCi/L, picocuries per liter] 


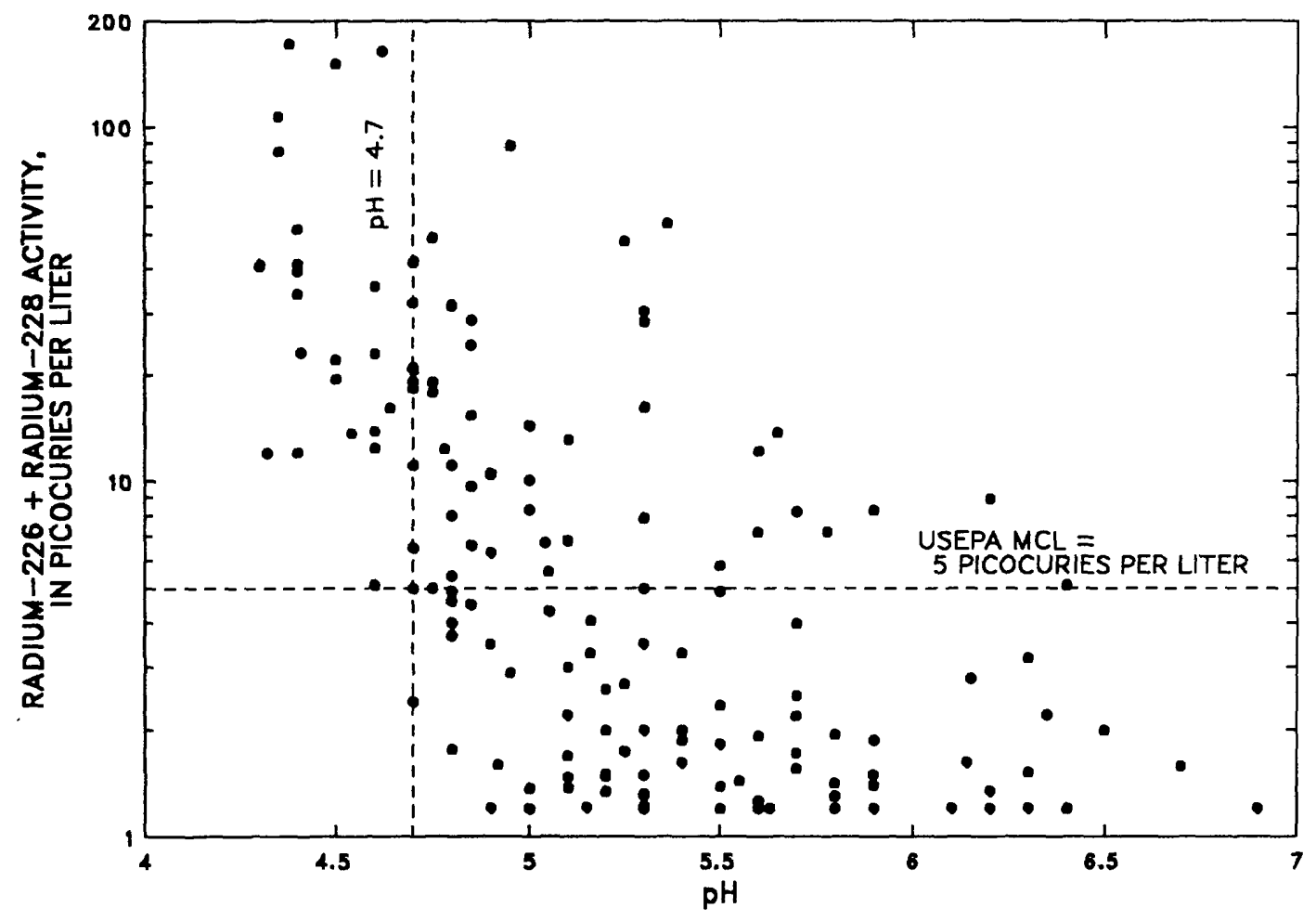

Figure 21. Relation between the sum of radium-226 plus radium-228 and $\mathrm{pH}$ for ground water in th? Chickies Quartzite. [USEPA MCL, U.S. Environmental Protection Agency Maximum Contaminant Level; pCi/L, picocuries per liter] 
Because $\mathrm{pH}$ is an important geochemical control in general, negative correlations are expected between $\mathrm{Ra}$ and constituents that correlate positively with $\mathrm{pH}$. Ra correlates negatively with alkalinity and $\mathrm{SiO}_{2}$ because both correlate positively with $\mathrm{pH}\left(\mathrm{r}_{\mathrm{s}}=0.65\right.$ and 0.55 , respectively) (table 6).

Maximum activities of $\mathrm{Ra}$ are observed in samples containing DOC concentrations above the median and having $\mathrm{pH}$ below the median (fig. 22). DOC concentrations, like Ra, also correlate negatively $\left(\mathrm{r}_{\mathrm{s}}=-0.53\right)$ with lower $\mathrm{pH}$ (table 6 ). The relation between decreasing $\mathrm{pH}$ and increasir . DOC may indicate decreased adsorption and slow degradation of DOC in acidic ground water (Thurman, 1985) or recharge from low $\mathrm{pH}$, DOC-rich waters of meteoric origin. Because natural DOC is commonly composed of organics acids that have equilibrium dissociation constants (pKa's) in the $\mathrm{pH}$ range of 3 to 5 (Lasaga, 1984), DOC may contribute to the acidity of the ground water. Howerer, high DOC concentrations appear to be associated with high $\mathrm{Ra}$ isotope activities independent of $\mathrm{pH}$ (fig. 22). Dissolved organic acids may enhance Ra mobility by complexation (Schubert and others, 1950). Thurman (1985) estimated that $1 \mathrm{mg} / \mathrm{L} \mathrm{DOC} \mathrm{has} \mathrm{about} 1$ microequivalent of metal-bindir 9 capacity, although that capacity generally decreases with decreasing $\mathrm{pH}$ because of hydrogen-ion competition for binding sites. The degree of ion complexation varies depending on $\mathrm{pH}$, relative binding capacities, specific complexing agents, and competing ions present (Stumm and Morgan. 1970). Thus, $\mathrm{Ra}$ ions may be preferably complexed by organic acids even at low $\mathrm{pH}$ despite the abundance of competing cations (sample median is 0.8 milliequivalents).

$\mathrm{Ba}$ is one of the heavier alkaline earth elements like $\mathrm{Ra}$, and, consequently, $\mathrm{Ba}$ and $\mathrm{Ra}$ can exhibit similar chemical behavior that is reflected in the strong positive correlation between $\mathrm{Ba}$ and $\mathrm{Ra}$. $\mathrm{Ba}$ also correlates positively (in decreasing order) with $\mathrm{DOC}, \mathrm{NO}_{3}$, specific conductance, $\mathrm{Cl}$, I In, $\mathrm{Mg}, \mathrm{K}, \mathrm{Na}$, and $\mathrm{SO}_{4}$ and negatively with $\mathrm{pH}$ and alkalinity (table 6). The correlations for $\mathrm{Ba}$ are similar in magnitude to those for Ra. Relations between $\mathrm{Ba}$ and $\mathrm{SO}_{4}$ and $\mathrm{Ra}-226$ and $\mathrm{Ra}-228$ are shown in figure 23. The correlations among $\mathrm{Ba}, \mathrm{Ra}, \mathrm{SO}_{4}, \mathrm{DOC}$, specific conductance, and $\mathrm{pH}$ sugsest that precipitation and (or) coprecipitation of $\mathrm{Ra}$ as the relatively insoluble $\mathrm{Ba}$ and $\mathrm{Ra}$ sulfates [log Ksp = -10 and -11.4 , respectively (Riese, 1982)] do not limit dissolved Ra activities in ground waters in the Chickies Quartzite, especially where these waters have a low pH (less than 5.0), have concentrations of DOC greater than $1 \mathrm{mg} / \mathrm{L}$, and a relatively high specific conductance. Even whore the ground water appears to be oversaturated with respect to $\mathrm{Ba}$ and $\mathrm{Ra}$ sulfates in water, the activities of $\mathrm{Ra}-226$ and Ra-228 may remain elevated. Riese (1982) states that $\mathrm{Ra}$ activity will be. limited by precipitation of $\mathrm{RaSO}_{4}$ only in waters with extremely elevated concentrations of $\mathrm{SO}_{4}$ or extremely elevated concentrations of Ra. In the Chickies Quartzite, most elevated activities of Ra are found in ground-water samples that appear to be theoretically oversaturated with $\mathrm{BaSO}_{4}(\log$ of the

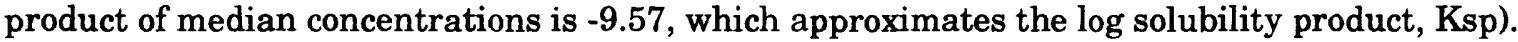

The relations among $\mathrm{pH}, \mathrm{Ra}, \mathrm{Ba}$, and $\mathrm{SO}_{4}$ could be the result of pyrite oxidation and dissolution, a process that decreases ground-water $\mathrm{pH}$, increases desorption of $\mathrm{Ba}$ and $\mathrm{Ra}$ from cation-bindin minerals, and increases dissolution of $\mathrm{Ba}$ - and Ra-bearing minerals. $\mathrm{SO}_{4}$ correlates negatively, b'tt weakly, with $\mathrm{pH}\left(\mathrm{r}_{\mathrm{s}}=-0.17\right)$, suggesting that pyrite may be a source of sulfate ions. The oxidation of dissolved ferrous $\mathrm{Fe}$ and precipitation of $\mathrm{Fe}(\mathrm{OH})_{3}$ following pyrite dissolution in oxygen-rich ground water causes further acidification. Oxidation of dissolved ferrous $\mathrm{Fe}$ is suggested by the negative correlations of total $\mathrm{Fe}$ with dissolved oxygen $\left(r_{\mathrm{s}}=-0.21\right)$. The lack of significant correlations betreen dissolved or total $\mathrm{Fe}$, and $\mathrm{SO}_{4}$ (table 6) may be caused by other controlling reactions or sources of $\mathrm{Fe}$ and $\mathrm{SO}_{4}$. For example, atmospheric deposition (acid rain) or fertilizer are sources of $\mathrm{SO}_{4}$ unaccompanied by $\mathrm{Fe}$. Minerals such as biotite and ilmenite are sources of $\mathrm{Fe}$ with no $\mathrm{SO}_{4}$. Ra also complexes with $\mathrm{SO}_{4}$ (Langmuir and Riese, 1985), a process that increases Ra solubility. 


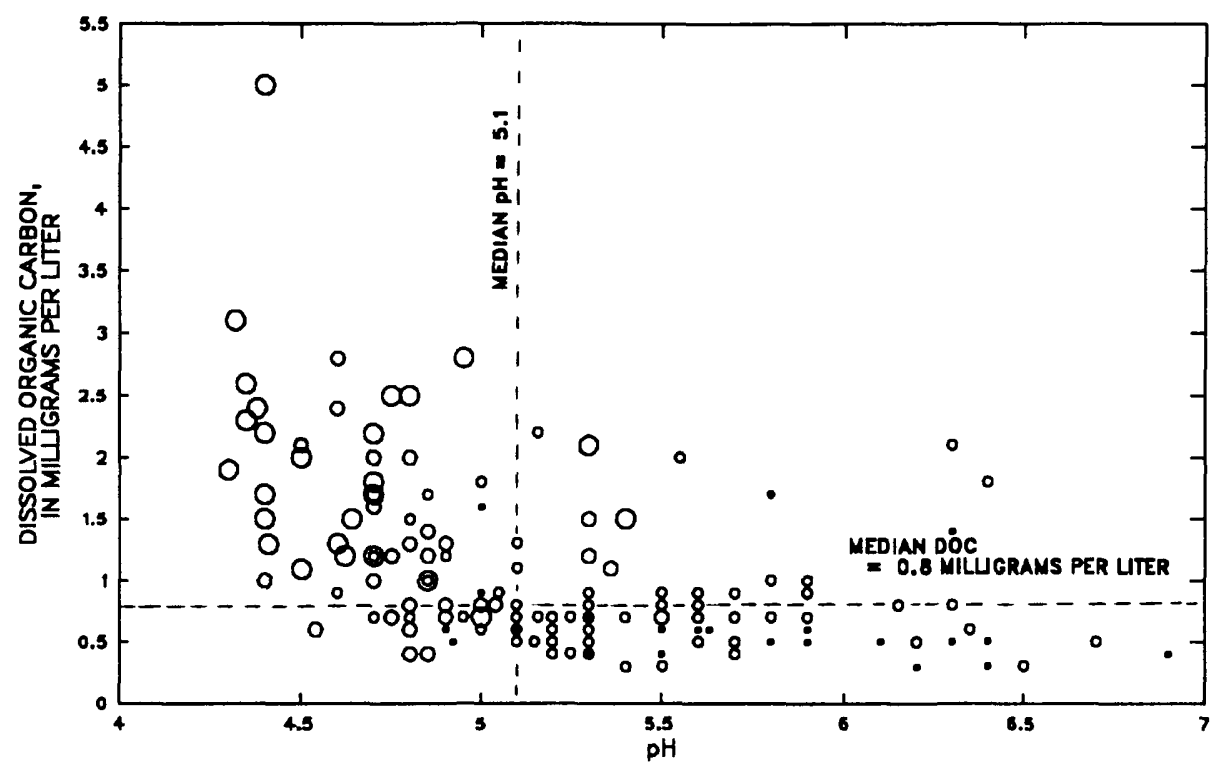

\section{EXPLANATION}

RADIUM-226 ACTIVITY,

- $\quad 0.2$

$0>0.2-2.0$

$0>2.0-5.0$

$0>5.0$

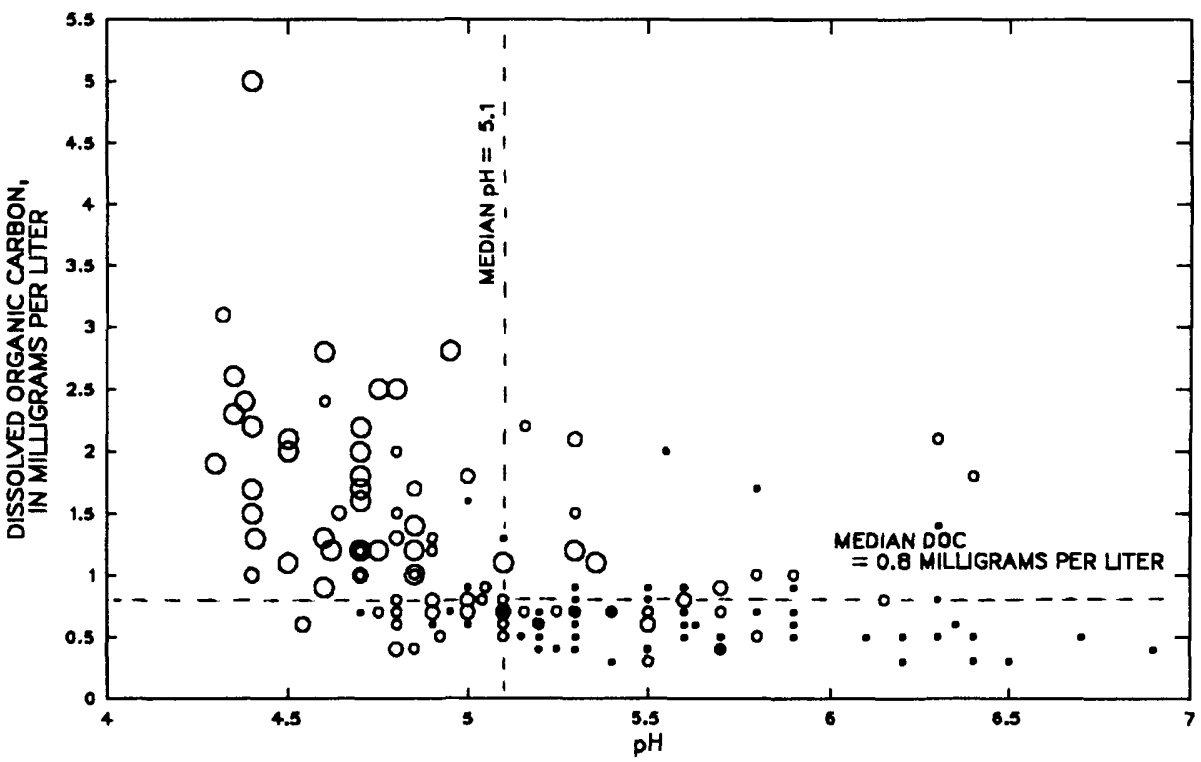

EXPLANATION

RADIUM-228 ACTIVITY. IN PICOCURIES PER LITER

$-<1.0$

$0>1.0-5.0$

$0>5.0-10.0$

$0>10.0$

Figure 22. Relation among dissolved organic carbon, $\mathrm{pH}$, radium-226, and radium-228 in ground water from the Chickies Quartzite. 

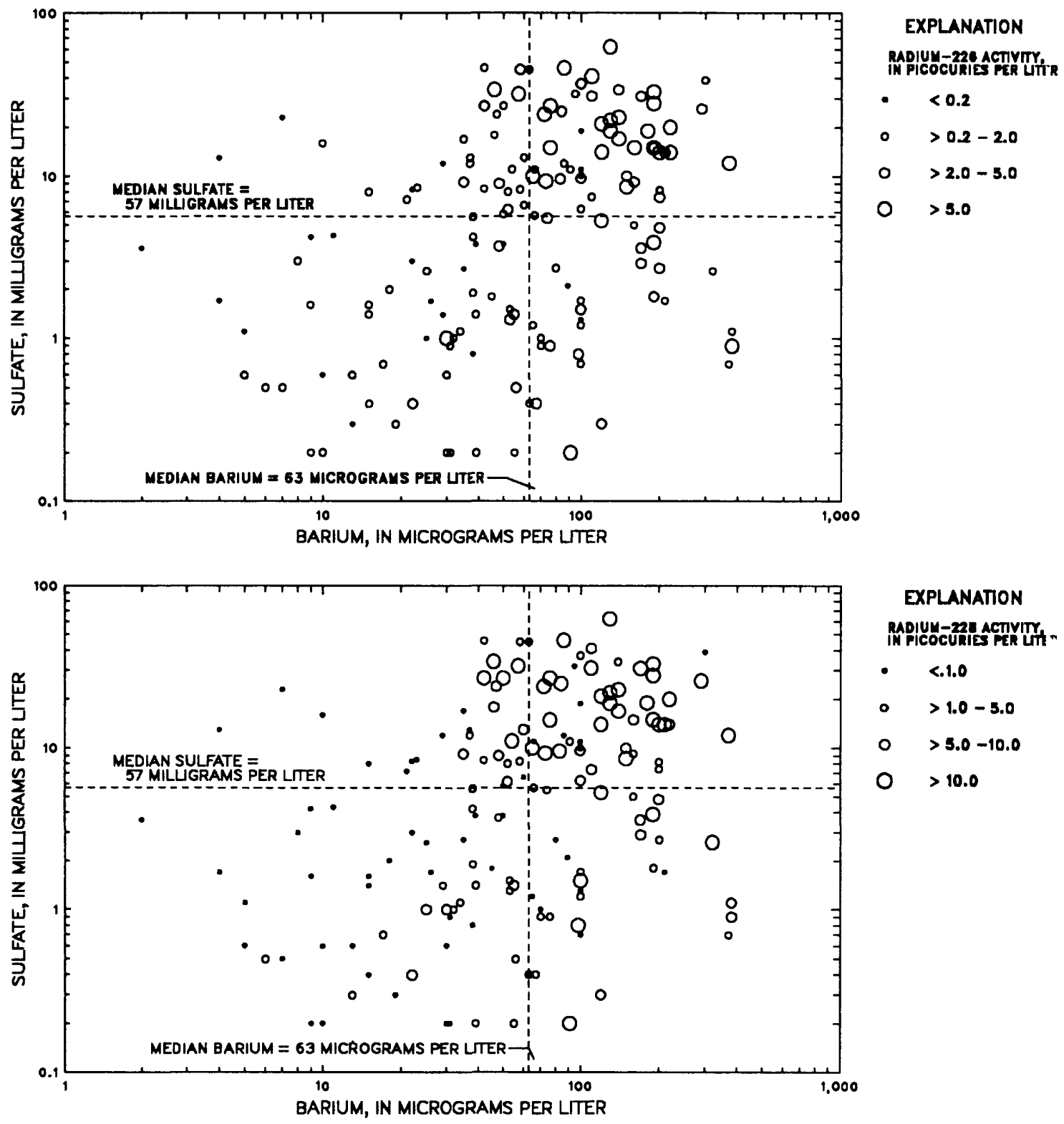

Figure 23. Relation among barium, $\mathrm{pH}$, sulfate, radium-226, and radium-228 in ground water from the Chickies Quartzite. 
The positive correlation between $\mathrm{Ra}$ and $\mathrm{Mn}$ and negative correlation between $\mathrm{Mn}$ and $\mathrm{pH}$ ? $\left(r_{s}=-0.26\right)$ indicate that the mobility of $\mathrm{Mn}$, like $\mathrm{Ra}$, increases as $\mathrm{pH}$ decreases. $\mathrm{Mn}$ also correlates with DOC $\left(r_{s}=0.33\right)$. Mn is soluble in its reduced form, and DOC can act as a reducing agent. Dissolution of some Mn-bearing minerals, including Mn oxides, in reducing, low $\mathrm{pH}$ water may be accompanied by concurrent release of $\mathrm{Ra}$ that otherwise might be adsorbed by $\mathrm{Mn}$ oxides and hydroxides.

$\mathrm{Ra}$ correlates positively with specific conductance, $\mathrm{Cl}$, and TDS. Ra solubility may be greater in water with higher specific conductance because ion solubility tends to increase with increases ir specific conductance and ionic strength and because increasing concentrations of competing ions limits adsorption. In laboratory experiments, leaching of $\mathrm{Ra}$ from $\mathrm{U}$ and $\mathrm{Th}$ ores was enhanced toy increasing concentrations of $\mathrm{NaCl}$, and the leaching was further enhanced by lowering $\mathrm{pH}$; $\mathrm{Na}-\mathrm{Ra}$ ion exchange was interpreted to be part of the process (Dickson, 1985). However, elevated Ra activities are found only in high specific-conductance waters of low $\mathrm{pH}$ (low alkalinity) because $\mathrm{pH}$ appears to be the dominant control on $\mathrm{Ra}$ sorption in the Chickies Quartzite, as indicated by the relative strength of correlations between $\mathrm{Ra}$ and $\mathrm{pH}$ and between $\mathrm{Ra}$ and specific conductance. $\mathrm{Ra}$ also forms complexes with $\mathrm{Cl}$ (Langmuir and Riese, 1985), as it does with $\mathrm{SO}_{4}$, that may increase Ra solub:lity.

Thus, the general ground-water chemistry associated with elevated $\mathrm{Ra}$ for 160 ground-water samples from the Chickies Quartzite is as follows, where the ground water: (1) has relatively low $\mathrm{pH}$ and elevated concentrations of DOC; (2) can contain relatively higher concentrations (above the median) of $\mathrm{Ba}$ and $\mathrm{SO}_{4}$; (3) has relatively high specific conductance; (4) has low alkalinity; and (5) also may contain elevated concentrations of $\mathrm{NO}_{3}, \mathrm{NaCl}$, or other constituents from septic systems, rcad salt, or fertilizers. This type of ground water could have had a short residence time in the aquif $\epsilon^{r}$ or retain the chemical character of recharge water because of the unreactive nature of the bedrock.

Distribution of $\mathrm{pH}, \mathrm{DOC}, \mathrm{Ba}$, and $\mathrm{SO}_{4}$, the chemical property and constituents with the strongest statistical correlations to $\mathrm{Ra}$, are shown, by lithology, in boxplots (fig. 24) to determine whether geochemical environments favorable to Ra mobility are more common in a particular lithology. Ground water from the conglomerate and quartzite is more acidic and contains greater concentrations of $\mathrm{DOC}, \mathrm{Ba}, \mathrm{SO}_{4}$ (fig. 24), $\mathrm{Ra}-226$, and $\mathrm{Ra}-228$ than the ground water from the slate. None of the nine ground-water samples from the slate contained elevated $\mathrm{Ra}$, although the small number of samples may not be representative of ground water in the lithlogy as a whole.

Spearman's rho correlation test was used to determine the chemical constituents and phyrical properties that correlated with Rn-222 in ground water. Because the MCT indicated that the quartzite and slate represent a different population than the conglomerate, data for the slate an $\mathrm{d}$ the quartzite were combined. Results of the Spearman's rho correlation tests (table 16) show that correlations among Rn-222 and chemical constituents and physical properties differ between the two lithologic groups. Only the inverse correlation with $\mathrm{SO}_{4}$ is shared by the all lithologies (table 16). Sulfate positively correlates with $\mathrm{Ra}$. Sulfate may directly enhance $\mathrm{Ra}$ mobility or may be in the low $\mathrm{pH}$ waters associated with elevated $\mathrm{Ra}$ such that $\mathrm{Ra}$ is not sorbed as well in the presence of elevated $\mathrm{SO}_{4}$. $\mathrm{Rn}-222$ concentrations in ground water may be lower where $\mathrm{Ra}$ is mobile. The different significant correlations suggest different geochemical controls on $\mathrm{Rn}-222$ in the quartzite than the conglomerate, despițe similar ground-water chemistry.

The correlation analysis for the conglomerate shows that Rn-222 activity is inversely correlated with concentrations of dissolved Fe. The relatively greater concentrations of dissolved Fe may reflect a relatively greater abundance of Fe-bearing minerals (pyrite or biotite) associated with U-bearing minerals in the solid phase. $U$ and Ra sorb onto Fe-oxides and biotite (Ames and Walker, 1983b; Ames and others, 1983). Rn-222 is negatively correlated with $\mathrm{Ba}, \mathrm{SO}_{4}, \mathrm{DOC}$, TDS, and specific conductance; these chemical constituents and property all are positively correlated with $\mathrm{Ra}$. The chemical environment associated with Rn-222 is opposite of the chemical environment that favors Ra motility. 

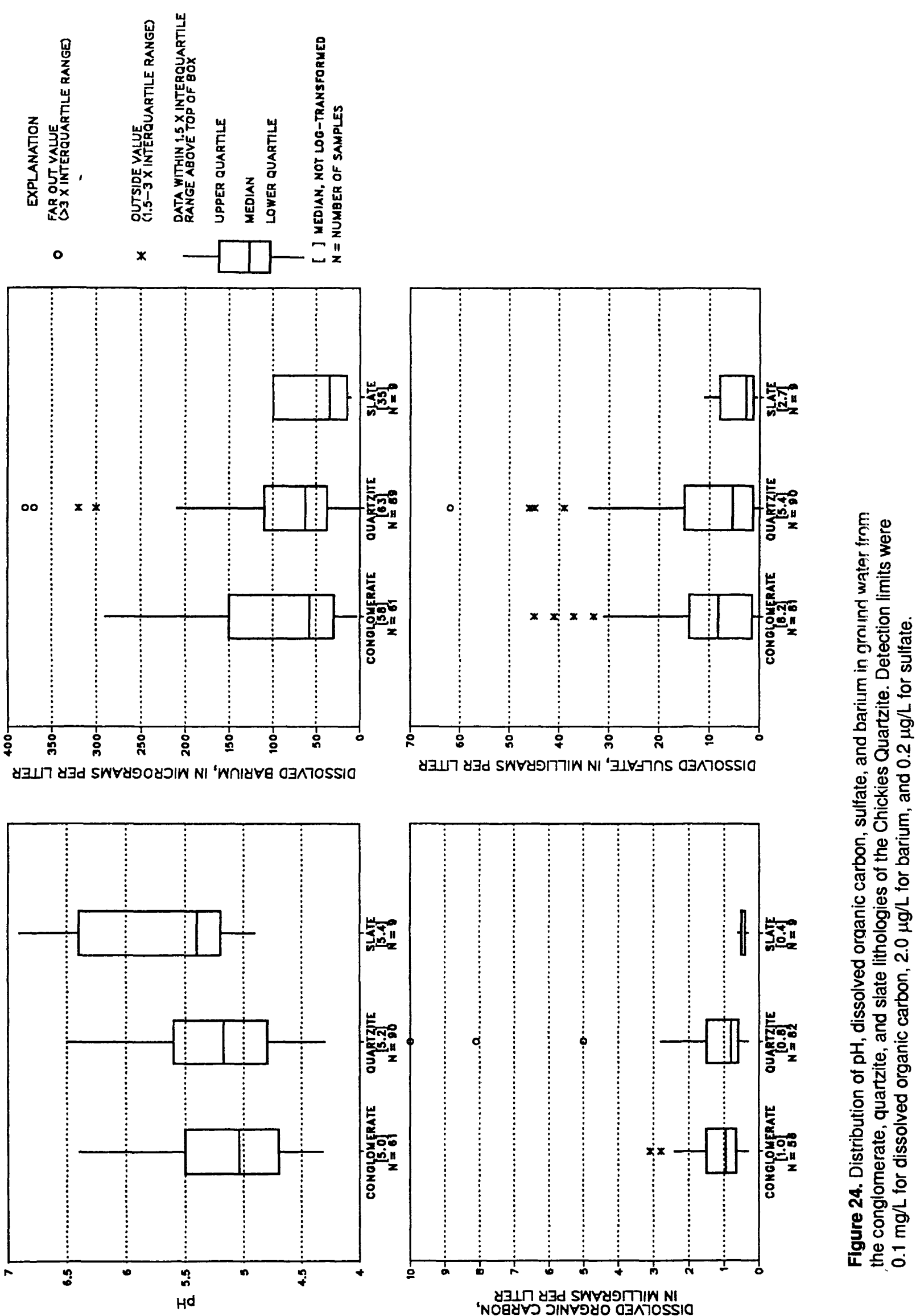
Table 16. Correlations between radon-222 and chemical constituents and properties significant at the 95-percentconfidence interval for ground-water samples from 160 wells in the Chickies Quartzite

$\left[r_{s}\right.$, Spearman rho correlation coefficient $]$

\begin{tabular}{|c|c|c|c|c|c|}
\hline \multicolumn{3}{|c|}{ Conglomerate } & \multicolumn{3}{|c|}{ Quartzite and slate } \\
\hline $\begin{array}{l}\text { Chemical constituent } \\
\text { or property }\end{array}$ & $r_{s}$ & $p$-value & $\begin{array}{c}\text { Chemical constituent } \\
\text { or property }\end{array}$ & $r_{s}$ & p-value \\
\hline Fe, dissolved & -0.42 & 0.0009 & $\mathrm{NO}_{3}$ & 0.45 & 0.0091 \\
\hline $\mathrm{Ba}$ & -.36 & .0051 & $\mathbf{K}$ & .38 & .0001 \\
\hline $\mathrm{SO}_{4}$ & -.32 & .0120 & $\mathrm{SO}_{4}$ & -.27 & .0081 \\
\hline DOC & -.29 & .0306 & $\mathrm{SiO}_{2}$ & .23 & .0220 \\
\hline TDS & -.29 & .0260 & $\mathbf{F}$ & -.23 & .0236 \\
\hline Specific conductance & -.27 & .0367 & & & \\
\hline
\end{tabular}

For the quartzite and slate, the strongest positive correlation is between $\mathrm{NO}_{3}$ and $\mathrm{Rn}-222$ (table 16). Elevated activities of Rn-222 in ground water could be present where the aquifer is susceptible to contamination by septic systems, fertilizers, or other sources of $\mathrm{NO}_{3}$ through relatively rapid infiltration of surface water; the conditions for rapid infiltration can include a relatively large rock-water surface-area ratio related to extensive fracturing or weathering that yields relatively large Rn-222 concentrations. The positive correlation between $\mathrm{Rn}-222$ and $\mathrm{SiO}_{2}$ and negative correlation between $\mathrm{Rn}-222$ and $\mathrm{SO}_{4}$ are opposite those of $\mathrm{Ra}$ and are indicative of a geochemical environment that does not favor $\mathrm{Ra}$ mobility. The positive correlations between $\mathrm{Rn}-222$ and $\mathrm{K}$ and between $\mathrm{Rn}-222$ and $\mathrm{SiO}_{2}$ also suggest that $\mathrm{Rn}-222$ is associated with areas of the quartzite containing more $\mathrm{K}$-bearing silicates, such as muscovite, that can sorb $U$ and $\mathrm{Ra}$ (Ames and others, 1983a, 1983b).

Because Rn-222 in ground water has a short half life, it does not travel far from its source (Fing and others, 1982). Elevated Rn-222 activity in ground water can occur where Ra-226 (and U) is relatively concentrated in or on aquifer materials. The general ground-water chemistry associate $\mathrm{X}$ with elevated $\mathrm{Rn}-222$ activity in the Chickies Quartzite is relatively low concentrations of $\mathrm{SO}_{4}$, and $\mathrm{Fe}$ and relatively high concentrations of $\mathrm{SiO}_{2}, \mathrm{~K}$, and $\mathrm{U}$. The general ground-water chemistry indicates that higher $\mathrm{Rn}-222$ activity is found where Ra-226 is likely to be concentrated in aquifer materials.

Aquifer and well-construction characteristics..-The concentrations of $R a$ and $R n$ in ground water are controlled partly by the rock-water ratio and rate of flushing or ground-water movement. Spearman's rho correlation test was used to determine if significant correlations exist between Ra-226, Ra-228, and Rn-222 activity and aquifer and well-construction characteristics. Tested variables include topographic setting (hillside or hilltop), well depth, reported casing length, well yield, specific capacity, and depth to water below land surface.

Significant negative correlations were found only between Ra activity and both specific caparity $\left(r_{s}=-0.37\right.$ for both Ra-226 and Ra-228) and casing length $\left(r_{s}=-0.26\right.$ for Ra-226 and -0.32 for Ra-228). No significant correlations were found between Rn-222 and aquifer and well-construction characteristics. Wells with a low specific capacity penetrate rock containing few fractures that are small and not well connected; therefore, the rock has low overall hydraulic conductivity and the $\mathrm{Ra}$ in solution has little chance of being diluted.

Casing commonly is set slightly below the depth where competent bedrock is encountered in drilling; therefore, the length of casing commonly indicates the depth of weathering or depth to competent bedrock. Casing length correlates positively with $\mathrm{SiO}_{2}$ and alkalinity; the concentratior $\&$ of these constituents that negatively correlate with $\mathrm{Ra}$ increase by chemical weathering. Casing len $: t h$ correlates negatively with $\mathrm{DOC}, \mathrm{Cl}, \mathrm{Na}, \mathrm{Mg}$, and $\mathrm{SO}_{4}$; the concentrations of these chemical constituents that correlate positively with $\mathrm{Ra}$ decrease with increasing length of casing. The correlations 
among these chemical constituents, casing length, and Ra suggest that elevated Ra in ground water is associated with areas of the aquifer that have undergone relatively less extensive chemical weathering. Also, leaching of $U, T h$, and Ra occur during weathering of the bedrock (Michel and others, 1978); thus, the depth of weathering can indicate the extent to which sources of $\mathrm{Ra}$ in tho rock are depleted in the zone flushed during recharge.

\section{Hydrogeologic setting}

The chemical composition of ground water, which includes dissolved Ra and $\mathrm{Rn}$, reflects the hydrogeologic setting and is related to aquifer mineralogy, the origin of the ground water, and the chemical and physical changes that occur during ground-water flow. The hydrogeologic setting of the Chickies Quartzite is controlled by lithology; the quartzite lithology commonly caps ridges, and the underlying conglomerate crops out just below one side of the ridge crest. The overlying Harpers Phyllite and Antietam Quartzite crops out downslope on the other side of the crest. The strike of the Chickies Quartzite is roughly parallel to the ridge line.

Sets of wells located on transects perpendicular and parallel to strike were sampled to investigate changes in water chemistry caused by lithologic changes and ground-water flow acr iss and along strike. Changes in water quality in a series of wells located along a down-gradient tre.nsect in a fractured-rock aquifer can progress along the vertical and horizontal flow paths. Transects perpendicular to strike included wells in adjacent aquifers to investigate ground-water transpo 't of $\mathrm{Ra}$ and $\mathrm{Rn}$ across lithologic units. The detection of Ra-226 and $\mathrm{Ra}-228$ in springs CH-SP-33 and BK-SP-21 (table 22) shows that Ra can be transported in ground water to surface discharge points. Transects were selected on the basis of availability of wells, geology, and known elevated Ra activities in ground water in the vicinity.

Schematic hydrogeologic sections showing chemical characteristics of Ra and Rn-222 activities and $\mathrm{pH}$ in well water, well depth, altitudes of land surface and the water table, and lithology for transects perpendicular and parallel to strike are discussed below to illustrate general conditions. The $\mathrm{Ra}$ and $\mathrm{Rn}-222$ activities in ground water from individual wells in any hydrogeologic setting may not conform to general patterns because of local variability of controlling factors discussed in the preceding sections.

Transects perpendicular to strike.-.Five transects perpendicular to strike that include wells near or in the crystalline rocks are located on Welsh Mountain and Mine Ridge in Lancaster County and in the Barren Hills southeast of Honeybrook in Chester County (fig. 25).

Generally, the transects show that water from wells drilled at the ridge crest has relatively greater Ra activities, lower $\mathrm{Rn}-222$ activities, and lower $\mathrm{pH}$ than water from wells on slopes. Correlation between $\mathrm{Ra}$ and Rn-222 activities and topographic setting (hilltop or slope) was not statistically significant for the categories tested, although low $\mathrm{pH}$ correlated with hilltop wells. Water from wells located downgradient and at or near the contact between the Chickies Quartzite and underlying crystalline rocks commonly contained relatively low total $\mathrm{Ra}$ activities, elevated $\mathrm{Rn}-222$ activities, and had a higher $\mathrm{pH}$ than water from ridge-crest wells. Ground water from wells on $s^{1}$ opes correlated positively with $\mathrm{SiO}_{2}$ and alkalinity.

Lithologic comparisons generally indicate that ground water in the conglomerate, which is nearest the crystalline-rock contact, contains more $\mathrm{Rn}-222$ than ground water in the quartzite. This relation may reflect the higher $U$ content of the conglomerate. The flow path, as well as litholog: can be an important factor controlling $\mathrm{Ra}$ and $\mathrm{Rn}-222$ activity and $\mathrm{pH}$ in ground water sampled progressively downgradient from the ridge crest. Chemical reactions, such as dissolution of minorals, can increase $\mathrm{pH}$ and decrease sorption causing changes in water chemistry along a flow path from recharge at ridge crests to discharge at Chickies Quartzite-crystalline rock contacts. 


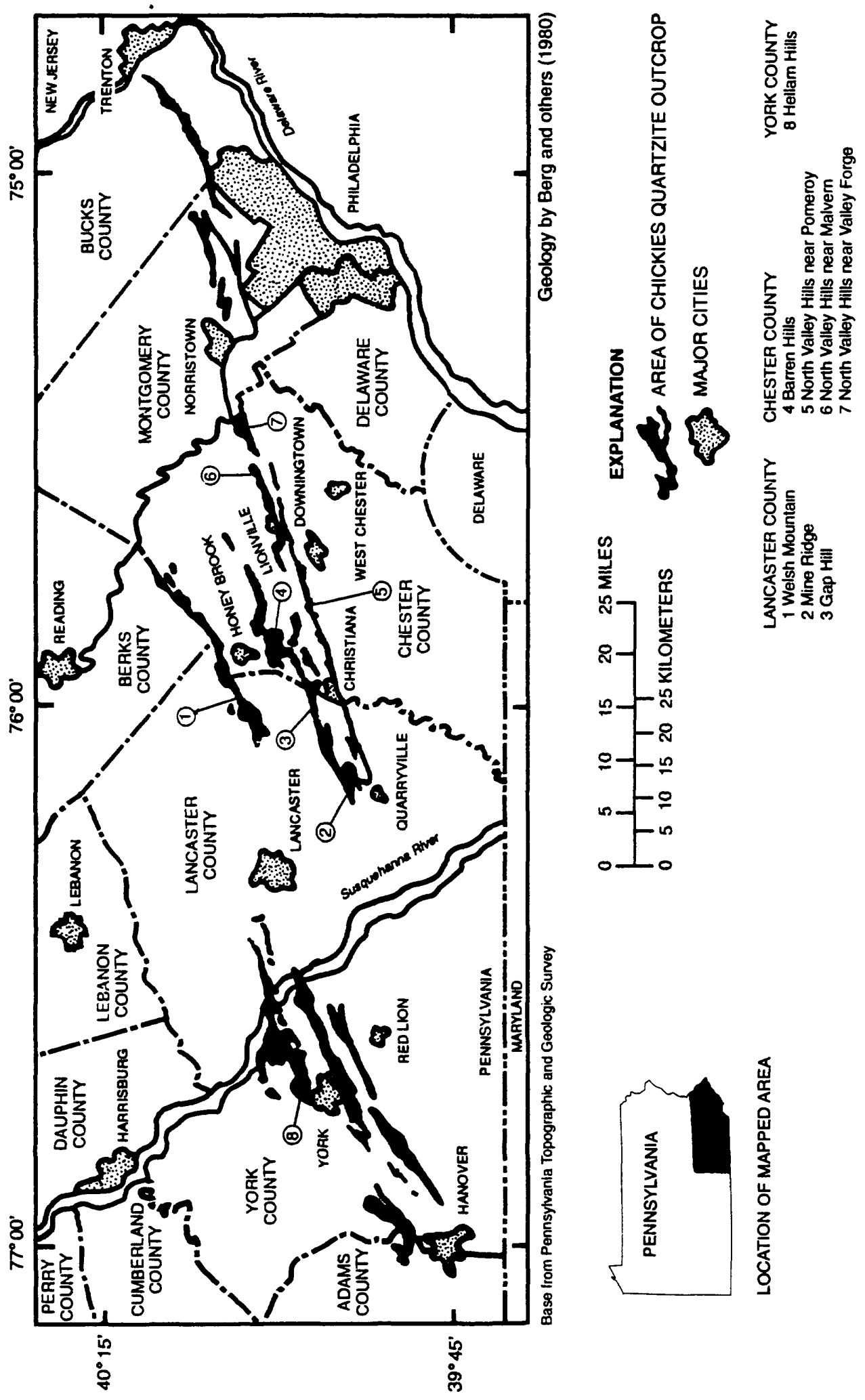

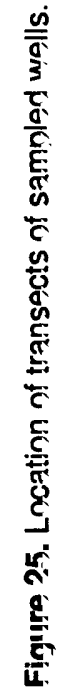


Two closely spaced transects are on Welsh Mountain near Narvon, Lancaster Countrr (fig. 26). One transect includes three wells and runs nearly perpendicular from the contact with the Precambrian crystalline rocks to the ridge crest (fig. 27). The other transect, located about $0.25 \mathrm{mi}$ to the west along strike (fig. 27), includes four wells and also runs perpendicular to strike from the conglomerate north to the mid-section of overlying quartzite lithology. Water-level measurements indicate that the ground-water divide is located at the ridge crest; ground water flows to the north and the south from the ridge crest.

$\mathrm{Ra}$ activities are greatest and $\mathrm{Rn}-222$ activities and $\mathrm{pH}$ are lowest in water from wells at the ridge crest compared to wells on slopes. The $\mathrm{Rn}-222$ activities in water from wells downslope from the ridge crest could be caused by high $U$ content of the aquifer as inferred from gamma-ray logs of wells near the crystalline rock contact (see logs of $\mathrm{LN}-1713$ and $\mathrm{LN}-1715$, in appendix). Ra-226 is immobilized by precipitation and (or) adsorbtion as the $\mathrm{pH}$ increases downgradient in the aquifer. Because $\mathrm{pH}$ is an important control on Ra mobility, the relatively greater $\mathrm{Rn}-222$ activities in water from downslope wells can reflect immobilization of Ra that originated upgradient in the acidic recharge zone on ridge crests.

These general conditions are also seen in other transects perpendicular to strike that include wells in adjacent sedimentary rocks (fig. 25). Generally, water from wells on ridge crests in the Chickies Quartzite contains higher total $\mathrm{Ra}$ activities and has a lower $\mathrm{pH}$ than water from downgradient wells in the Chickies Quartzite and overlying sedimentary rocks. Rn-222 activities in water from wells in the Chickies Quartzite are similar to those in water from wells in the Harpers Phyllite and Antietam Quartzite but greater than those in water from wells in carbonate rocks. Rn-222 in the ground water in the Harpers Phyllite and Antietam Quartzite is derived frcm U in the aquifer materials and (or) from the precipitation or adsorption of dissolved $\mathrm{Ra}$ originating in the Chickies Quartzite. The median U concentration (3.6 ppm) for three rock samples of Harpers Phyllite and Antietam Quartzite is as great or greater than median $U$ concentrations for samples of the Chickies Quartzite (tables 8 and 9). The low Ra activities in water samples from wells in carbonate rocks indicates that $R a$ is not mobile or that little $R a$ is present in aquifer materials. The low $R n-222$ activities in water from the carbonate rocks reflects low $U$ concentration in aquifer materials and (or) dilution of $\mathrm{Rn}-222$ in carbonate aquifers with comparatively high hydraulic conductivity. 

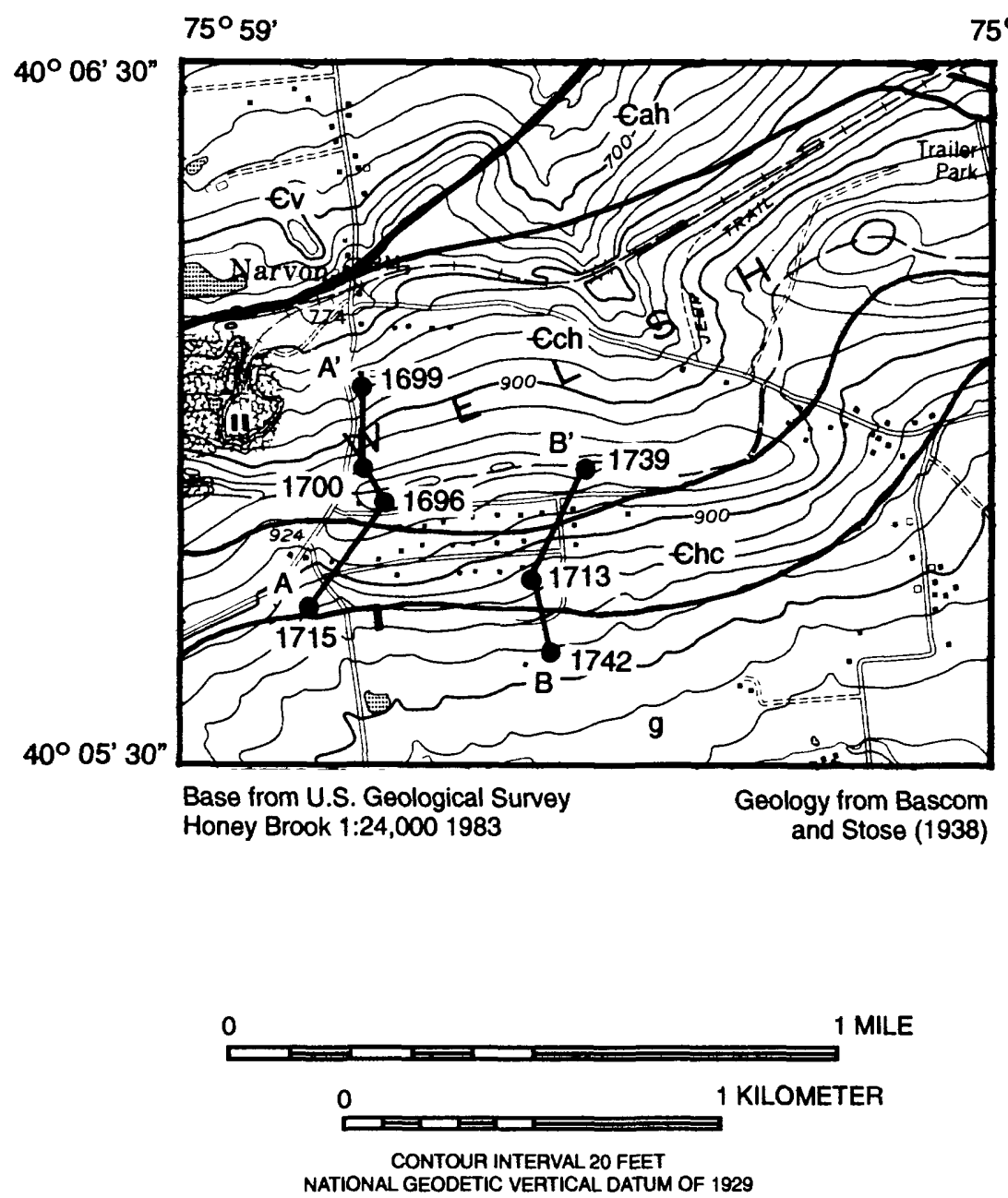

EXPLANATION

$\begin{array}{ll}\text { €ah } & \text { HARPERS PHYLLITE AND } \\ & \text { ANTIETAM QUARTZITE, undivided } \\ \text { €ch } & \text { CHICKIES QUARTZITE - quartzite } \\ \text { Chc } & \text { CHICKIES QUARTZITE - conglomerate } \\ \mathrm{g} & \text { GNEISS } \\ \text { Cv } & \text { VINTAGE DOLOMITE }\end{array}$

- 1696 WELL AND IDENTIFICATION NUMBER A A' LINE OF CROSS SECTION

- FAULT, dashed where infered

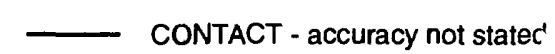

Figure 26. Geology and location of selected wells, Welsh Mountain, Lancaster County. 

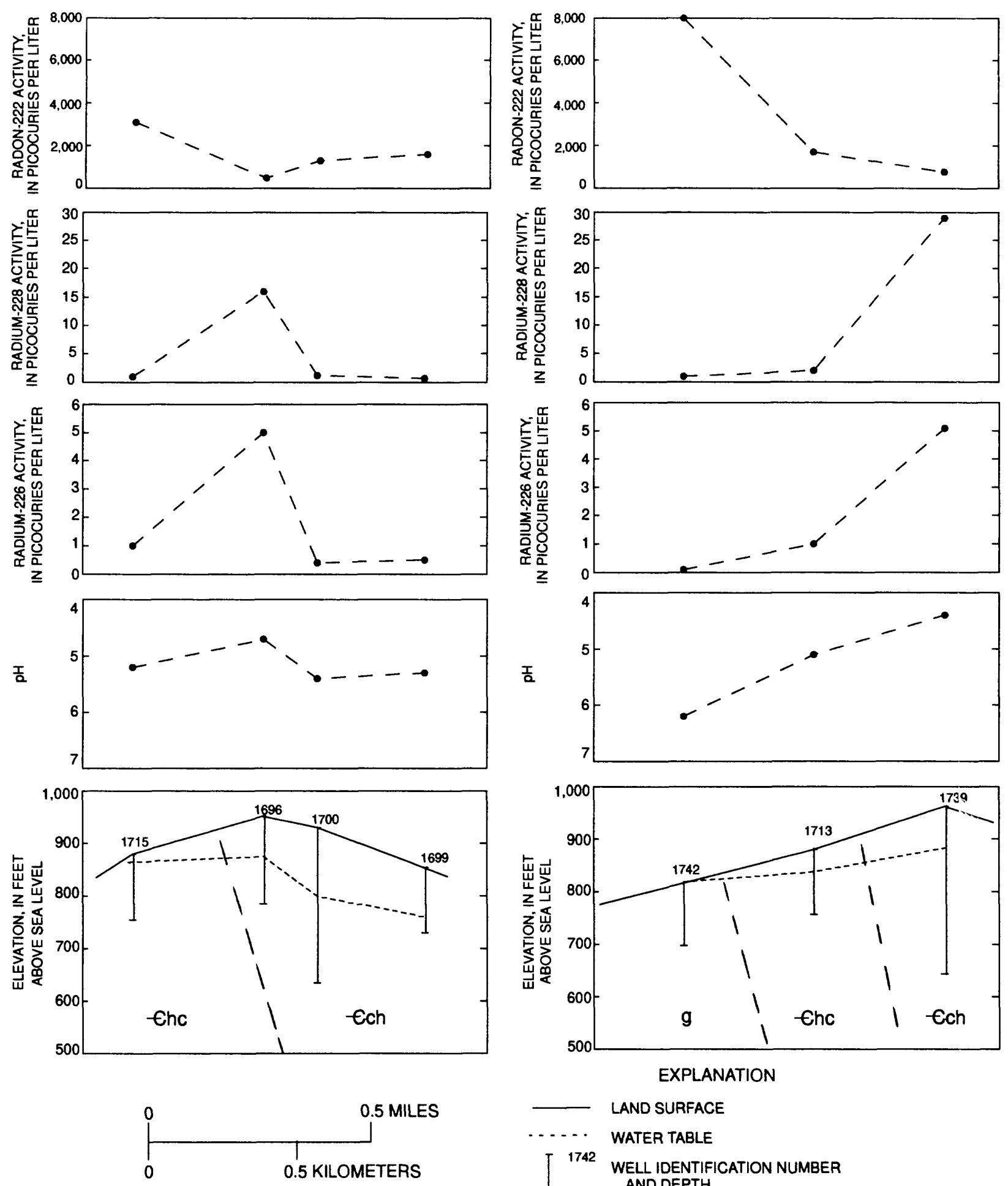

\section{EXPLANATION}

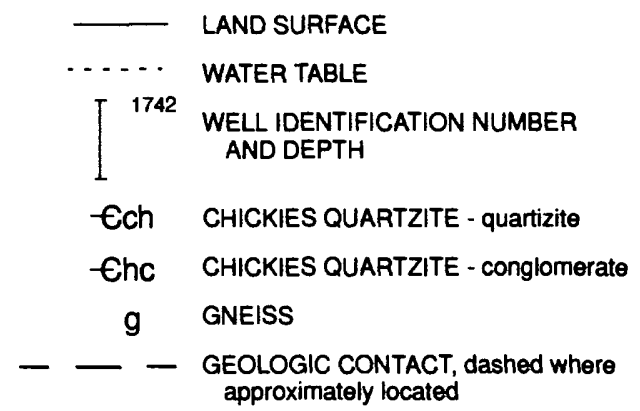

Figure 27. Radium and radon activities and $\mathrm{pH}$ in ground water and schematic geologic sections perpendicular to strike, Welsh Mountain, Lancaster County. 
Transects parallel to strike,--Five transects parallel to strike that include wells on ridge crests are located on Mine Ridge in Lancaster County west of Gap, in the Barren Hills in Chester County southeast of Honeybrook, and in the North Valley Hills in Chester County north of Malvirn and near Valley Forge (fig. 25). Generally, the transects show that Ra and Rn-222 activities and pH in water from wells along the ridge crest are similar as a result of similar aquifer composition and hydro'ngic conditions along strike. Rn-222 activities appear to vary less in water from wells along a ridge crest than in water from wells on slopes. On Mine Ridge, the contact between the conglomerate and quartzite lithologies underlies the crest, and there activities of $\mathrm{Rn}-222$ are greater in wells on the crest than slopes. One of these transect areas is described below.

Two sets of wells were sampled along strike in the Barren Hills, Chester County (figs. 28 ع.nd 29). Both sets of wells are drilled near the ridge crest where the altitude of the land surface and the water table changes little along the transect. Water from wells $\mathrm{CH}-3327, \mathrm{CH}-3315, \mathrm{CH}-3213$, and $\mathrm{CI}^{\mathrm{T}}-3219$ along transect A-A' (fig. 29) contain Ra activities greater than $20 \mathrm{pCi} / \mathrm{L}$. Water samples from we'ls $\mathrm{CH}$ 3189, CH-1098, CH-3166, and CH-1094 along transect B-B' (fig. 29) contain Ra activities less tl an 10 $\mathrm{pCi} / \mathrm{L}$. Both sets of wells are in similar hydrogeologic settings. Water from wells within in each set contains a similar range of $\mathrm{Ra}$ and $\mathrm{Rn}-222$ activities for that set. The difference in the range of $\mathrm{Pa}$ activity between the sets of wells probably reflects differences in the $U$ and Th content of the aq'ifer.

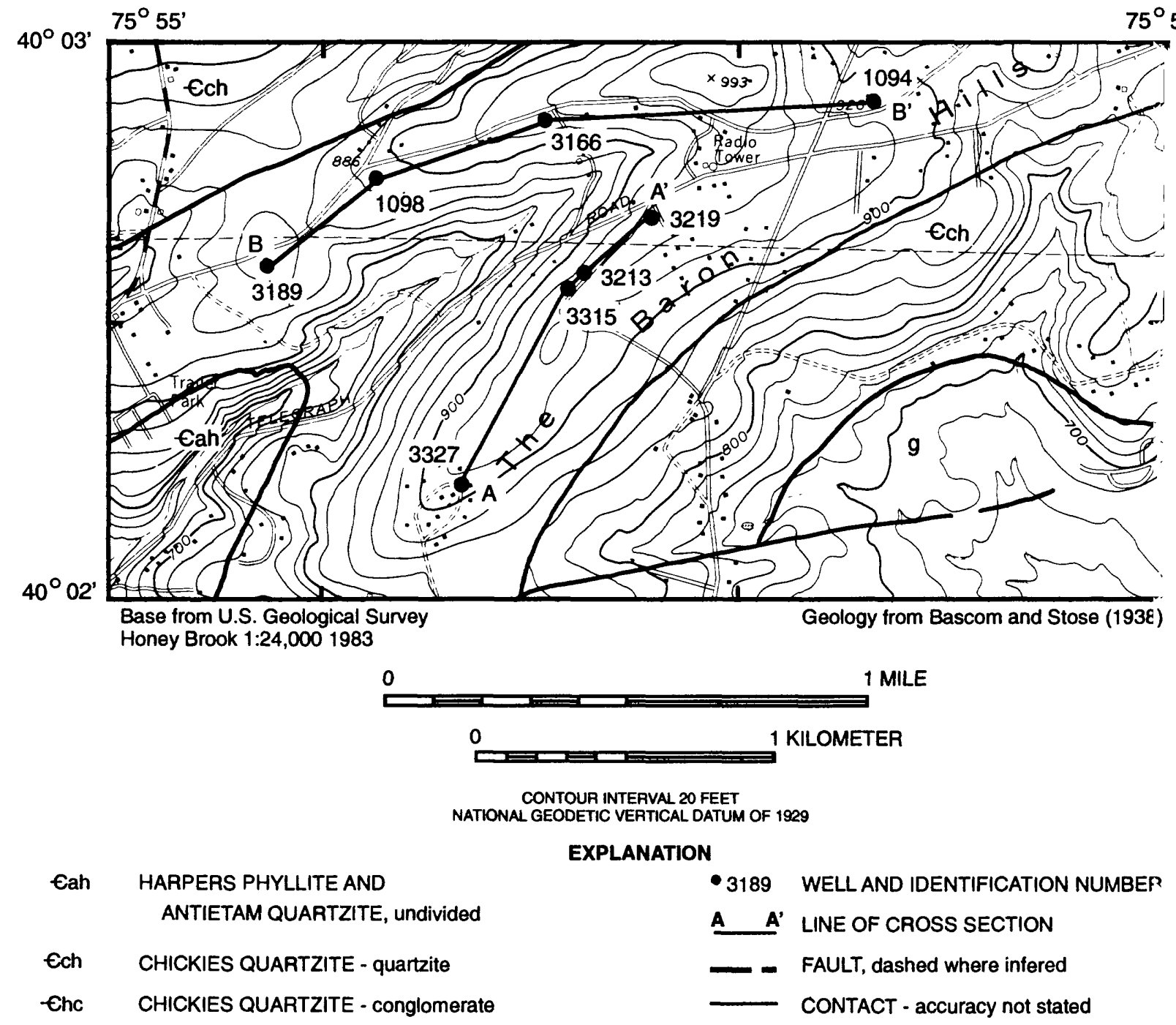

g GNEISS

Figure 28. Geology and locations of selected wells, Barren Hills, Chester County. 


\section{EXPLANATION}

$\begin{array}{cl}---- & \text { LAND SURFACE } \\ -3189 & \text { WATER TABLE } \\ & \begin{array}{c}\text { WELL IDENTIFICATION NUMBER } \\ \text { ANDEPTH }\end{array} \\ - \text { Ech } & \text { CHICKIES QUARTZITE - quartzite }\end{array}$

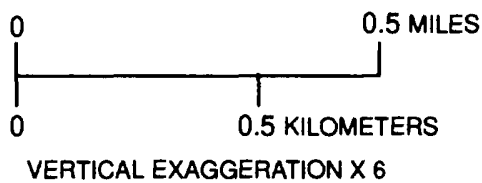

Figure 29. Radium and radon activities and $\mathrm{pH}$ in ground water and schematic geologic sections parallel to strike, Barren Hills, Chester County.
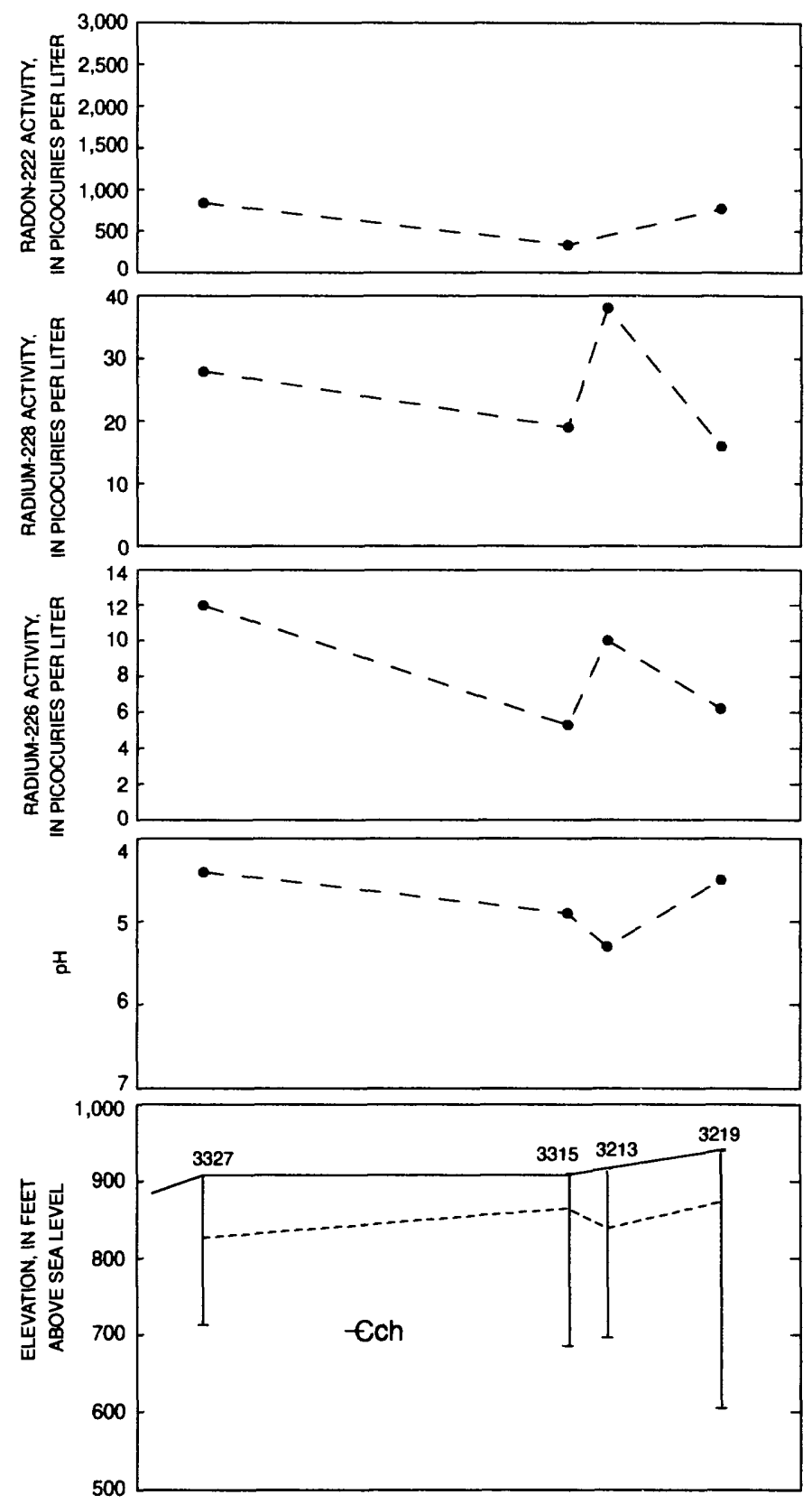

Local variability,--Ra and $\mathrm{Rn}-222$ activities and water chemistry differ locally as well as regionally. Water from nearby wells with similar depths does not necessarily contain similar $\mathrm{Ra}$ and Rn-222 activities. Local variability represents departures from general patterns described in the discussions on transects. The transects generally show elevated $\mathrm{Ra}$ activities and low $\mathrm{pH}$ in wate- from ridge crest wells; elevated Rn-222 activities generally are found in water from wells drilled into the conglomerate lithology and from wells drilled on slopes. Factors unique to each well that affect lo sal variability of $\mathrm{Ra}, \mathrm{Rn}-222$, and water chemistry include well characteristics (depth, yield, specific capacity, location of water-bearing zones, and casing length), position in the flow path, and aquifer mineralogy and lithology. Fracture patterns also differ, exposing different sections of the lithologies to ground-water flow.

Six sets of closely spaced wells with similar geologic and hydrologic settings were sampled to investigate the local variability of water chemistry. Each set includes two to three wells sampled on the same day. The wells are in Welsh Mountain and Gap Hill in Lancaster County, and in the North Valley Hills near Malvern in Chester County (fig. 25). Selected data for these wells are given in table 17. 

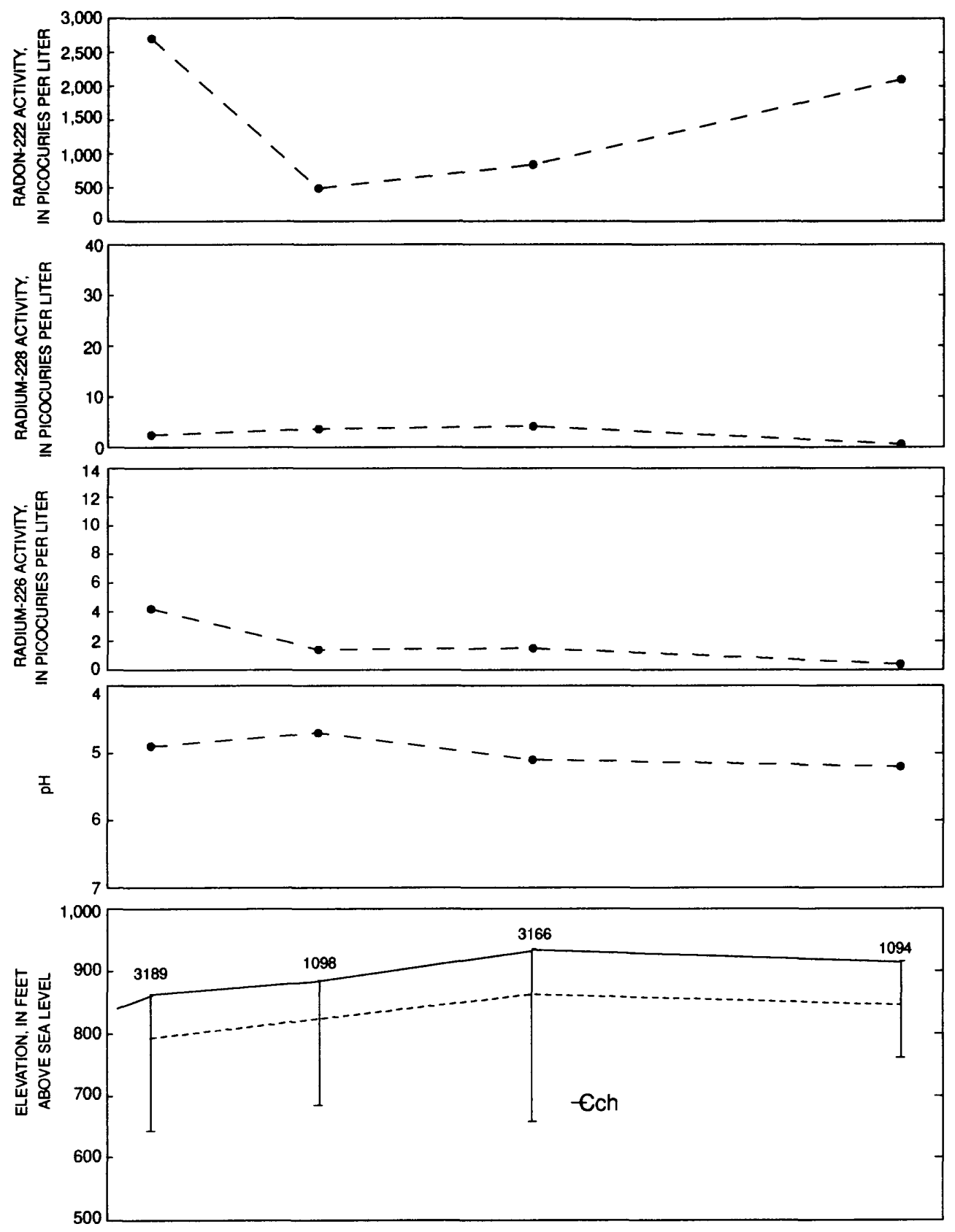

Three closely spaced wells (LN-1738, LN-1740, and LN-1741) located on a ridge crest on Welsh Mountain were sampled. Water samples from these wells show that ground-water chemistry, including radium activities, may be similar if the water is derived from similar depths but can differ by depth from well to well in a small area. The results also show that not all water from wells on ridge crests in the Chickies Quartzite contains elevated Ra activities. Water samples from wells LN-1740 and LN-1741 come from at least one water-bearing zone of similar depth, have a similer chemical character ( $\mathrm{pH}$ of 5.3, similar specific conductance, and low $\mathrm{DOC}, \mathrm{Ba}$, and $\mathrm{SO}_{4}$ concentrations), and low $\mathrm{Ra}$ and Rn-222 activities (table 17). Well LN-1738, which is located nearby, is drilled deeper and taps deeper water-bearing zones than wells LN-1740 and LN-1741. Water from well LN-1738 has only slightly higher Rn-222 activities, but is more acidic and has a higher specific conductance, higher $\mathrm{DOC}, \mathrm{Ba}$, and $\mathrm{SO}_{4}$ concentrations, and higher $\mathrm{Ra}$ activities than water from the other two wells. Because the Rn-222 activities are similar in samples from this group of wells, chemical factors probably account for the observed differences in radium activities more than otler factors, such as the distribution of $U$ in aquifer materials or well characteristics. 


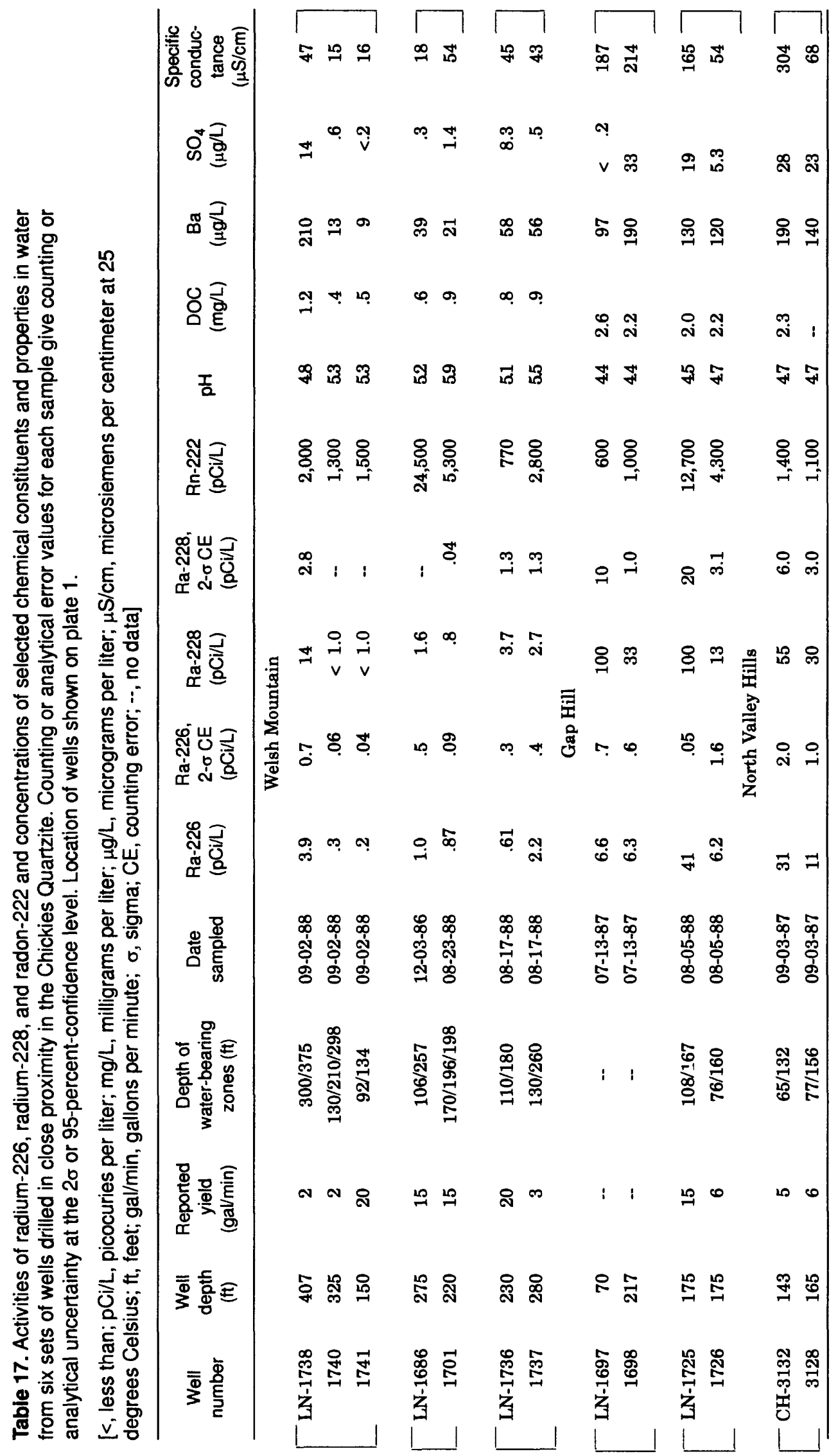


Wells LN-1686 and LN-1701, located on a slope on Welsh Mountain, are about $300 \mathrm{ft}$ apart and have the same reported yield, but the depths of water-bearing zones differ (table 17). Both wells lave elevated Rn-222 activities and similar, moderate radium activities, yet water from well LN-1686 has more than five times the Rn-222 activity than does the water from well LN-1701 (table 17). Despite the proximity and similarity of the two wells, factors affecting Rn-222 activities appear to differ ly individual water-bearing zones in the aquifer. These differences in Rn-222 activities in ground water probably reflect differences in the concentration of $U$ and $R a-226$ sources and(or) emanation rate: from host minerals near the wells, because other physical factors, such as well yield (a measure of aquifer porosity) and hydrologic setting, for the two wells are similar.

Water from wells LN-1736 and LN-1737, located near a ridge crest on Welsh Mountain, has similar chemistry, contains similar Ra-228 activities, but different Ra-226 and Rn-222 activities. Water from well LN-1737 contains a higher Ra-226 activity, despite having higher $\mathrm{pH}$, and a hig] er Rn-222 activity than water from well LN-1736 nearby. This suggests that the aquifer may contain similar amounts of Th, but more $U$ and(or) Ra-226 in aquifer materials in the immediate area of well LN-1737 than in the area near LN-1736.

Differences in $\mathrm{Rn}-222$, Ra-226, and Ra-228 activities were measured in water from two pairs of closely spaced wells near the ridge crest on Gap Hill. Water from wells LN-1697, LN-1698, LN-1\%25, and $\mathrm{LN}-1726$ has a relatively similar chemical character (low $\mathrm{pH}$, high specific conductance, except for well LN-1726, and high DOC concentrations) that apparently favors Ra mobility, and elevated activities of Ra-226 and Ra-228 were measured in each water sample (table 17). The differences in $\mathrm{Ra}-228, \mathrm{Ra}-226$, and $\mathrm{Rn}-222$ activities in water from these wells probably reflect differences in aquifer mineralogy, including locally variable distribution of both Th and $U$.

Elevated Ra activities were measured in water from two wells (CH-3128, CH-3132) with low $\mathrm{pH}$ and relatively high DOC and $\mathrm{SO}_{4}$ concentrations, located near a ridge crest in the North Valley Hills (table 17). The wells differ only slightly in depth, yield, and depth of water-bearing zones, and water from the wells contains similar Rn-222 activities. Although radium activities are elevated in water from both wells, water from well $\mathrm{CH}-3132$ contains substantially more radium-226 and radium-228 than water from well $\mathrm{CH}-3128$. This set of wells shows that elevated $\mathrm{Ra}$ in a range of concentrations is found in ground water with characteristics favoring Ra mobility and that differences in the radium activities can be greater than the differences in $\mathrm{Rn}-222$ activities in closely spaced wells with similar construction and hydraulic characteristics.

Thus, results of sampling closely spaced wells show that the chemical character of ground water commonly is similar in one area, but $\mathrm{Ra}$ and $\mathrm{Rn}-222$ activities can range over two orders of magnitude. Ra activities of similar magnitude tend to be found in water from wells in similar hydrogeologic settings, although elevated $\mathrm{Ra}$ activities are not necessarily present in ground water with geochemical conditions favorable for $\mathrm{Ra}$ mobility. $\mathrm{Rn}-222$ activity in ground water differs from well to well, but commonly is similar in water from wells in similar hydrogeologic settings. Ra and $\mathrm{Rn}-222$ activities in ground water may be unpredictable in fractured-rock aquifers with variable $U$ and Th distribution, variable mineralogy (caused by sedimentary facies changes), variable hydraulic conductivity, fracture spacing, and complex flow paths. $R a$ and $R n-222$ generally do not travel in ground water far from sources because of the short-half life of Rn-222 and rapid sorption of $\mathrm{Ra}$ from aqueous phase onto aquifer materials (King and others, 1982).

\section{Distributions in Adjacent Geologic Units}

Ground water from a total of 28 wells in geologic units adjacent to the Chickies Quartzite u'as sampled to determine the radiochemical activities of these formations, the relative magnitude of $\mathrm{Ra}$ and $\mathrm{Rn}$ activities, and the possible effect of migration of Ra-rich waters from the Chickies Quartzite. Water samples were taken from wells penetrating the Harpers Phyllite and Antietam Quartzite, carbonate rocks and crystalline rocks immediately adjacent to and downgradient from the Chickies Quartzite (within $1 \mathrm{mi}$ of the contact). The crystalline-rock units include felsic, intermediate, and mafic gneiss. The carbonate units are the Ledger Dolomite, Conestoga Limestone, and Vintage Dolomite. Range and median values of $\mathrm{Ra}-226, \mathrm{Ra}-228$, and $\mathrm{Rn}-222$ activities and $\mathrm{U}$ concentrations in water samples are given in table 18.

Of the adjacent units, only water samples from wells penetrating the Harpers Phyllite and Antietam Quartzite contained Ra activities greater than $5 \mathrm{pCi} / \mathrm{L}$. Ground water in these units is acidic (median is 5.3; $\mathrm{pH}$ range is 4.9 to 6.6). The median and range of $\mathrm{Rn}-222$ activities in ground water in the Harpers Phyllite and Antietam Quartzite (median is $2,300 \mathrm{pCi} / \mathrm{L}$; range is 228$25,300 \mathrm{pCi} / \mathrm{L}$ ) is about equal to that of the Chickies Quartzite (median is $2,400 \mathrm{pCi} / \mathrm{L}$; range is 114 . 
$32,300 \mathrm{pCi} / \mathrm{L}) . \mathrm{Ra}$ enrichment of ground water in adjacent units by migration of $\mathrm{Ra}$ in ground water from the Chickies Quartzite is not indicated by the data. The analysis of cuttings from wells drilled in Harpers Phyllite and Antietam Quartzite indicate that $U$ and Th concentrations in these rocks are similar to $U$ and Th concentrations in the Chickies Quartzite (table 9), and, therefore, the sourres of $R a$ and Rn-222 in ground water in the Harpers Phyllite and Antietam Quartzite are minerals in these units.

The low $\mathrm{Ra}$ and $\mathrm{Rn}-222$ activities in the ground water in carbonate rocks may reflect geochemical conditions unfavorable for Ra mobility (median $\mathrm{pH} 7.3$; range 7.0 to 7.8), low $\mathrm{U}$ and $\mathrm{Th}$ content of aquifer materials, and possibly dilution because of higher permeability. Slightly greater concentrations of $U$ are observed in the ground water in carbonate rocks than in the ground water in other rocks because the mobility of $U$ tends to increase in high $\mathrm{pH}$, bicarbonate-rich waters.

The 10 water samples from the crystalline rocks are grouped into water samples from eit] er felsic or basic rocks for comparison because of the small sample size for individual rock units. $U$ and Th content of felsic rocks generally is greater than that of mafic rocks (table 7). For the wells sanipled, ground water in felsic rocks has a lower $\mathrm{pH}$ (median 5.5) than ground water in mafic rocks (median 6.4). The highest $R \mathrm{a}$ and $\mathrm{Rn}-222$ activities and $U$ concentrations in water from a well in crystalline rock were detected in amphibolite facies of a felsic and intermediate gneiss (CH-3117).

In addition to wells that penetrate only adjacent geologic units, wells drilled through the contact between the Chickies Quartzite and adjacent geologic units also were sampled. Elevated $\mathrm{Ra}$ activities were not detected in water from wells drilled through the Chickies Quartzite into other geologic units. Water samples from well MG-1003, which probably penetrates the Ledger Dolomite, and wells CH-3122, CH-3135, and LN-1742, which penetrate Precambrian crystalline rocks, have a relatively high $\mathrm{pH}$ which reduces $\mathrm{Ra}$ mobility. $\mathrm{Rn}-222$ activities in these water samples range from $76 \mathrm{pCi} / \mathrm{L}$ for well MG-1003 to $9,200 \mathrm{pCi} / \mathrm{L}$ for well $\mathrm{CH}-3122$; the $\mathrm{Rn}-222$ activity partly depends $\mathrm{c} n$ the $\mathrm{U}$ content of the contributing aquifers. Some of the highest $\mathrm{Rn}-222$ activities (up to $30,000 \mathrm{pCi} / \mathrm{h}$ ) in the Chickies Quartzite were detected in water samples from wells (CH-3122, CH-3328, and CH-3337) drilled near the contact with mafic rocks; these elevated Rn-222 activities are probably caused by high $\mathrm{U}$ content of the Chickies Quartzite near the contact but could reflect increased precipitation of $\mathrm{Ra}$ at the contact with the mafic rocks, which have a higher $\mathrm{pH}$ ground water than does the Chickies Quartzite.

Table 18. Radium-226, radium-228, and radon-222 activities and uranium concentrations in ground water from geologic units adjacent to the Chickies Quartzite

[pCi/L, picocuries per liter; $\mu \mathrm{g} / \mathrm{L}$, micrograms per liter; --, insufficient data to calculate median]

\begin{tabular}{|c|c|c|c|c|}
\hline & \multirow{2}{*}{$\begin{array}{c}\text { Harpers Phyllite and } \\
\text { Antietam Quartzite, } \\
\text { undivided }\end{array}$} & \multirow{2}{*}{$\begin{array}{l}\text { Carbonate } \\
\text { rocks }\end{array}$} & \multicolumn{2}{|c|}{ Crystalline rocks } \\
\hline & & & felsic & basic \\
\hline Number of samples & 13 & 5 & 8 & 2 \\
\hline \multicolumn{5}{|l|}{$\mathrm{Ra}-226(\mathrm{oCj} / \mathrm{L})$} \\
\hline Minimum & $<.2$ & $<.2$ & $<.2$ & $<.2$ \\
\hline Maximum & 2.9 & 1.0 & 1.1 & .6 \\
\hline Median & .3 & $<.2$ & $<.2$ & -- \\
\hline \multicolumn{5}{|l|}{$\operatorname{Ra}-228(0 \mathrm{Ci} / \mathrm{L})$} \\
\hline Minimum & $<1.0$ & ${ }^{1}<1.0$ & $<1.0$ & $<1.0$ \\
\hline Maximum & 12 & -- & 1.7 & $<1.0$ \\
\hline Median & $<1.0$ & -- & $<1.0$ & -- \\
\hline \multicolumn{5}{|l|}{ Total Ra (oCi/L) } \\
\hline Minimum & $<1.2$ & $<1.2$ & $<1.2$ & $<1.2$ \\
\hline Maximum & 14.9 & $<2.0$ & 2.8 & $<1.6$ \\
\hline Median & 1.4 & $<1.2$ & $<1.2$ & -- \\
\hline \multicolumn{5}{|l|}{$\mathrm{Rn}-222(\mathrm{oC} / / \mathrm{L})$} \\
\hline Minimum & 230 & 65 & 140 & 1,600 \\
\hline Maximum & 25,300 & 520 & 8,200 & 8,000 \\
\hline Median & 2,300 & 366 & 900 & $-\cdot$ \\
\hline \multicolumn{5}{|l|}{$\mathrm{U}(\mathrm{mg} / \mathrm{h})$} \\
\hline Minimum & $<.05$ & $<.05$ & $<.05$ & $<.01$ \\
\hline Maximum & 1.8 & 2.4 & 1.7 & .25 \\
\hline Median & $<.05$ & .36 & $<.05$ & -- \\
\hline
\end{tabular}

${ }^{1}$ Ra-228 activity in all samples was less than detection limit. 


\section{Distribution in Other Quartzites in the Piedmont}

Other quartzites in Pennsylvania have acidic ground water that is part of a geochemical environment supportive of elevated Ra activities. Data from other quartzites that crop out in the Piedmont are discussed below to compare to data for the Chickies Quartzite. The Hardyston Quartzite is reported to contain monazite, a Th-rich mineral, as an "unusually common accessor:" (Smith, 1974; Aaron, 1969) and to have radioactive minerals in a thin bed near the base of the unit (Smith, 1975). The presence of Th-and U-bearing minerals in the aquifer matrix indicates that ground water in the Hardyston Quartzite could contain elevated $\mathrm{Ra}$ activities where geochemical conditions favor Ra mobility. Th-rich aquifer materials are associated with elevated Ra-228 activities in ground water.

One water sample was collected from a randomly selected well (BK-1288) that penetrates the Hardyston Quartzite on Buckingham Mountain in Bucks County. The sample contained $1.7 \mathrm{pCi} / \mathrm{L}$ $\mathrm{Ra}-226$ and $3.6 \mathrm{pCi} / \mathrm{L} \mathrm{Ra}-228(5.3 \mathrm{pCi} / \mathrm{L}$ total $\mathrm{Ra}), 12,000 \mathrm{pCi} / \mathrm{L} \mathrm{Rn}-222$, and $0.14 \mu \mathrm{g} / \mathrm{L} \mathrm{U}$. These activities and concentration are above the median but within the range for Chickies Quartzite ground-water samples.

The Setters Quartzite and the Peters Creek Schist (a quartzite schist) are Paleozoic or older, and are not clean quartzites like the Chickies Quartzite. Both units crop out south of the Chickies Quartzite and are associated with Wissahickon and Octoraro Schists. Ground-water samples from the Setters Quartzite and Peters Creek Schist in Chester County were analyzed for Ra-226, Ra-228, Rn-222 activities, and U concentration (Sloto, 1989). Water from some wells in both the Precamk rian Setters Quartzite and Peters Creek Schist contained some low, but detectable, activities of Ra-22a and Ra-228. The ground-water samples from the Peters Creek Schist contained relatively elevated activities of $\mathrm{Rn}-222$ (up to $9,100 \mathrm{pCi} / \mathrm{L}$, with a median of $5,800 \mathrm{pCi} / \mathrm{L}$ ). Probable sources of Th and $\mathrm{U}$ in the Setters Quartzite and Peters Creek Schist are minerals such as monazite and zircon that have been identified in the Wissahickon Schist (Dryden and Dryden, 1964). In comparison to the Chic'ries Quartzite, Ra mobility in the ground water of these aquifers may by limited by relatively less acidic or neutral $\mathrm{pH}$, greater abundance of sorption sites, and (or) other unfavorable geochemical conditions.

\section{Temporal Variability}

Ra-226, Ra-228, and Rn-222 activities and chemistry can vary in the water from a well through time. In order to determine if $\mathrm{Ra}-226, \mathrm{Ra}-228$, and $\mathrm{Rn}-222$ activities changed over time, 3 wells from different areas of the Chickies Quartzite (BK-1202, CH-3219, and YO-1148) were sampled twice, 1 well (CH-1616) 3 times, and 1 well (CH-3335) 14 times. Wells BK-1202 and $\mathrm{CH}-3219$ are drilled into the quartzite lithology and well YO-1148 is drilled into the conglomerate lithology of the Chickie: Quartzite. Wells CH-1616 and CH-3335 are near each other and drilled in the conglomerate litho'ngy. Water from wells sampled two or three times was analyzed for major and minor ions, Ra-226, Ra-228, $\mathrm{Rn}-222$, and $\mathrm{U}$. Water from well $\mathrm{CH}-3335$ was analyzed each time for Ra-226, Ra-228, Rn-222 activities, once for major and minor ions, and 10 times for $\mathrm{Cl}, \mathrm{SO}_{4}, \mathrm{NO}_{3}$, and $\mathrm{NH}_{4} . \mathrm{Ra}$ and $\mathrm{Rn}-222$ activities and selected chemical constituents and properties in water from wells $\mathrm{CH}-1616, \mathrm{CH}-32.19$, and BK-1202 are given in table 19. Complete chemical and radiochemical analyses for all wells are presented in tables 21 and 22, respectively.

$\mathrm{Ra}$ and Rn-222 activities in well-water samples fluctuate over periods of months; measured fluctuations range up to 40 percent of the lowest Rn-222 activity and more than 100 percent of tro lowest activities for Ra-226 and Ra-228. Increases in Rn-222 activities are not necessarily accompanied by increases or decreases in $\mathrm{Ra}$ in ground water. The smallest observed change (8 percent) in Rn-222 activity was in water from well $\mathrm{CH}-1616$, which was sampled three times in about 1 year. The largest observed change (40 percent) was in water from well YO-1148, which was sampled in the winter and summer. Another well, BK-1202, was also sampled in the winter and summer, but Rn-222 activity differed by only 9 percent. Water from wells in different hydrogeolo xic settings probably differ in the extent of temporal fluctuations in $\mathrm{Ra}$ and $\mathrm{Rn}-222$ activities; temporal variability may be caused by seasonal changes in water levels, recharge, and biological activity, cr by other changes, including withdrawal rates. 
Table 19. Activities of radium-226, radium-228, and radon-222 and concentrations of selected dissolved constituen+s and properties of water from wells in the Chickies Quartzite sampled more than once. Counting or analytical error values for each sample give counting or analytical uncertainty at the $2 \sigma$ or 95 -percent-confidence level.

[pCi/L, picocuries per liter; $\mathrm{mg} / \mathrm{L}$, milligrams per liter; $\mu \mathrm{S} / \mathrm{cm}$, microsiemens per centimeter at 25 degrees Celsius; $\mathrm{U}$, uranium; $\mu \mathrm{g} / \mathrm{L}$, micrograms per liter; $\sigma$, sigma; $C E$, counting error; $A E$, analytical error; --, no data]

\begin{tabular}{|c|c|c|c|c|c|c|c|c|c|c|c|c|}
\hline $\begin{array}{c}\text { Well } \\
\text { number }\end{array}$ & $\begin{array}{c}\text { Date } \\
\text { sampled }\end{array}$ & $\begin{array}{l}\text { Ra-226 } \\
\text { (pCi/L) }\end{array}$ & $\begin{array}{l}\mathrm{Ra}-226 \\
2-\sigma \mathrm{CE} \\
\text { (pCi/L) }\end{array}$ & $\begin{array}{l}\mathrm{Ra}-228 \\
\text { (pCi/L) }\end{array}$ & $\begin{array}{l}\text { Ra-228 } \\
2-\sigma C E \\
\text { (pCi/L) }\end{array}$ & $\begin{array}{l}\mathrm{Rn}-222 \\
\text { (pCi/L) }\end{array}$ & $\begin{array}{c}U \\
(\mu g / L)\end{array}$ & $\begin{array}{c}U \\
\text { 2- } \sigma A E \\
(m g / L)\end{array}$ & $\mathrm{pH}$ & $\begin{array}{c}D O C \\
(\mathrm{mg} / \mathrm{L})\end{array}$ & $\begin{array}{c}\mathrm{Ba} \\
\text { (mg/L) }\end{array}$ & $\begin{array}{c}\text { Specific } \\
\text { conduc- } \\
\text { tance } \\
(\mu \mathrm{S} / \mathrm{cm})\end{array}$ \\
\hline \multirow[t]{2}{*}{ BK-1202 } & $12-31-86$ & 3.8 & 0.5 & 50 & 2.0 & 2,600 & 0.33 & 0.05 & 5.4 & 1.1 & $<100$ & 58 \\
\hline & $05-07-87$ & 5.7 & .6 & 66 & 2.0 & 2,800 & .39 & .06 & 4.9 & - & 58 & 75 \\
\hline \multirow[t]{2}{*}{ CH-1265 } & $11-21-86$ & 2.7 & .5 & 2.7 & .7 & 370 & .18 & .03 & -- & - & - & -- \\
\hline & $05-06-87$ & 2.0 & .2 & 2.4 & .5 & -- & .23 & .03 & -- & -- & .- & .- \\
\hline \multirow[t]{3}{*}{ CH-1616 } & $11-12-86$ & 2.7 & .6 & 17 & 3.0 & 3,400 & .30 & .05 & 5.3 & 1.2 & 42 & 203 \\
\hline & $08-11-87$ & 2.9 & .1 & 25 & 1.0 & - & $<.05$ & -- & 5.0 & 1.0 & 40 & 230 \\
\hline & $10-23-87$ & 4.1 & .4 & 29 & 3.0 & 3,700 & .87 & .01 & 5.1 & -. & 40 & 242 \\
\hline \multirow[t]{2}{*}{ CH-3219 } & $06-16-87$ & 4.6 & .8 & 13 & 2.7 & 671 & -. & - & 5.4 & 1.4 & 53 & 44 \\
\hline & $08-23-87$ & 6.2 & 1.0 & 16 & 3.1 & 772 & .02 & .01 & 4.5 & 1.1 & 65 & 44 \\
\hline \multirow[t]{2}{*}{ YO-1148 } & $12-09-86$ & 5.4 & .6 & 9 & .9 & 20,300 & .86 & .13 & 5.0 & .7 & 30 & 48 \\
\hline & $07-22-87$ & 2.1 & .1 & 4 & .7 & 28,500 & .79 & .12 & 5.1 & .8 & 15 & 35 \\
\hline
\end{tabular}

Ra-226, Ra-228, and Rn-222 activities in water samples from well $\mathrm{CH}-3335$ exhibit a seasnnal rise and decline that is inversely related to the seasonal rise and decline of the water table and the $\mathrm{SO}_{4}$ concentrations. $\mathrm{Ra}-226$ activities ranged from 4.4 to $15.3 \mathrm{pCi} / \mathrm{L}, \mathrm{Ra}-228$ activities ranged from 64 to $160 \mathrm{pCi} / \mathrm{L}$, and $\mathrm{Rn}-222$ activities ranged from 2,800 to $7,900 \mathrm{pCi} / \mathrm{L}$ (table 22). Ra-226, Ra-228, and Rn-222 activities; $\mathrm{pH}, \mathrm{SO}_{4}$, and $\mathrm{NH}_{4}$ concentration; and depth to water in well CH-3335 are show'n in figure 30 for September 1988 through November 1989. The lowest Ra and Rn-222 activities occur during April-June when the water table is highest, concentrations of $\mathrm{SO}_{4}$ are greatest (up to $31 \mathrm{~m} \sigma / \mathrm{L}$ ), and concentrations of $\mathrm{NH}_{4}$ are lowest (below level of detection) (tables 21 and 22). These low $\mathrm{Ra}$ and $\mathrm{Rn}-222$ activities may reflect dilution by recharge of meteoric origin. Increased $\mathrm{SO}_{4}$ and decreased $\mathrm{NH}_{4}$ concentrations in ground water indicate more oxidizing conditions that are consistent with recharge through shallow fractures. Increased $\mathrm{SO}_{4}$ concentrations in ground water can be associated with $\mathrm{SO}_{4}$-enriched recharge, where sources are acid rain and $\mathrm{SO}_{4}$ accumulated in the unsaturated zone during dry periods. Precipitation collected in 1979-86 in Chester County west of well CH-3335 contained $\mathrm{SO}_{4}$ concentrations of up to $10 \mathrm{mg} / \mathrm{L}$.

The inverse temporal relation between $\mathrm{Ra}$ and $\mathrm{SO}_{4}$ for water from well CH-3335 is opposite to the positive correlation shown by statistical analysis of data for 160 wells sampled once. However, concentrations of $\mathrm{SO}_{4}$ in water from well CH-3335 (median concentration is $24 \mathrm{mg} / \mathrm{L}$ ) are relativoly elevated compared to all 160 wells (median of $5.7 \mathrm{mg} / \mathrm{L}$ ). Some ground water with elevated Ra activity (well LN-1697; for example, see table 17) do not contain an elevated $\mathrm{SO}_{4}$ concentration; this suggrests that the chemical relation between $\mathrm{Ra}$ and $\mathrm{SO}_{4}$ is not as strong as it is between $\mathrm{Ra}$ and other controlling factors, such as $\mathrm{pH}$. 

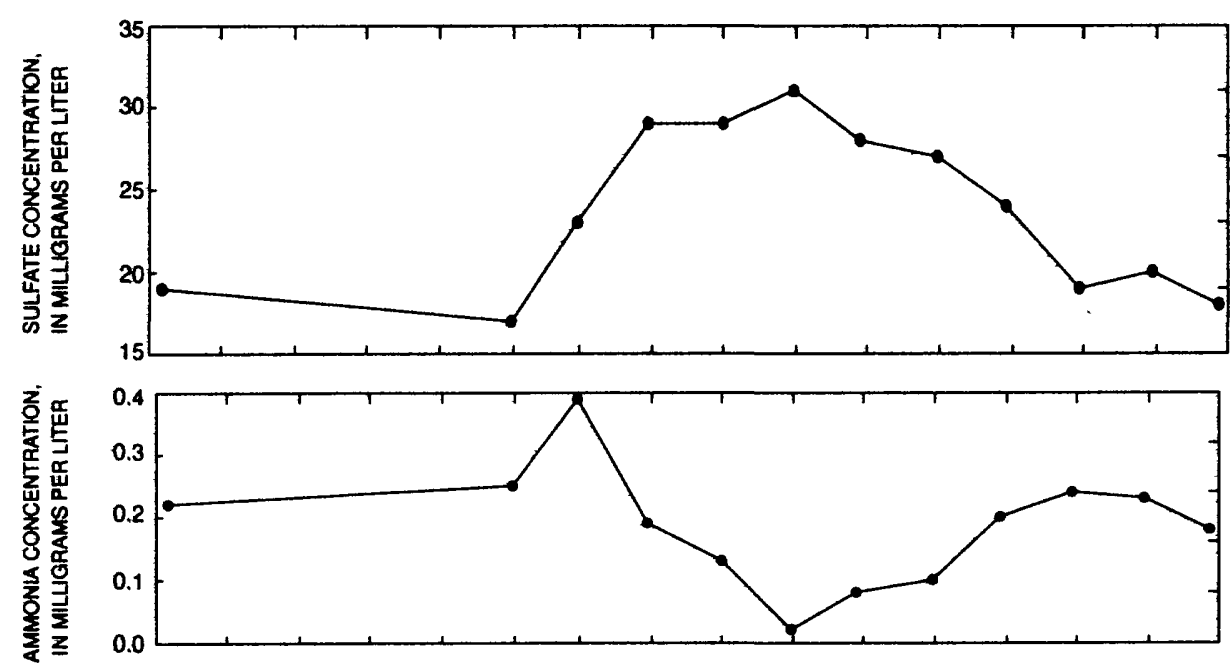

I
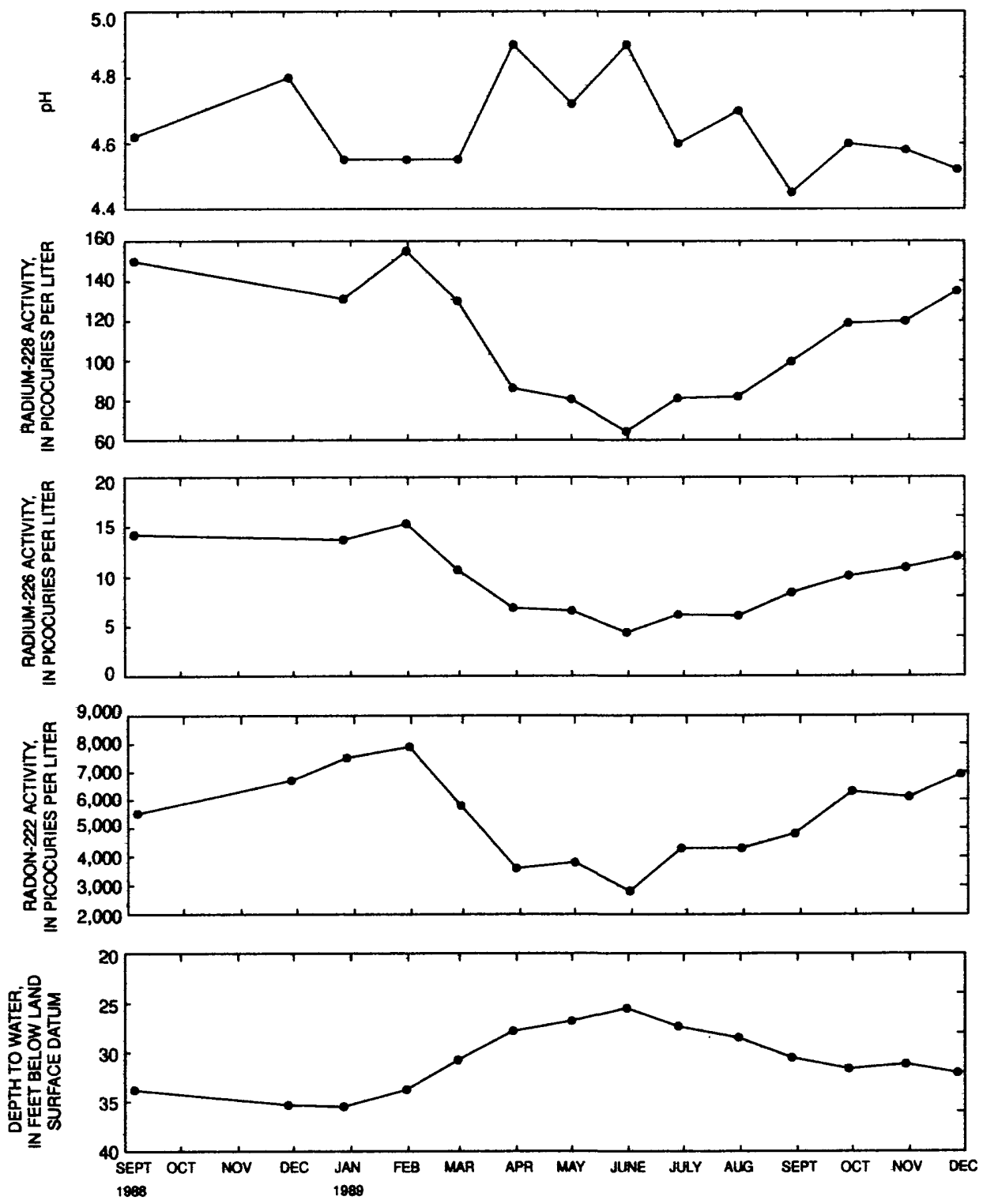

Figure 30. Relations among radon-222, radium-226, and radium228 activities; pH; sulfate and ammonic concentrations; and depth to water in we'l CH-3335, Septembe1988 to November 1989. 


\section{Conceptual Model of Radium and Radon in Ground Water}

Elevated $\mathrm{Ra}$ activities in ground water are found in a geochemical environment that favors $\mathrm{Ra}$ mobility. Ground-water chemistry depends on both geologic and hydrologic controls that include aquifer lithology and mineralogy, and flow paths. Primary sources of $\mathrm{Ra}$ in ground water are UJ- and Th-bearing minerals in the aquifer matrix. The abundance of $U$ and $T h$ in rocks is not as important as geochemical controls in determining $\mathrm{Ra}$ activities in ground water. Elevated activities of Ra-226 and Ra-228 are found in ground water in rocks that are not especially enriched in $U$, Th, and Ra bacause geochemical controls, such as $\mathrm{pH}$, limit solubility.

Elevated $\mathrm{Ra}$ in ground water in the Chickies Quartzite is associated with low $\mathrm{pH}$ waters. Differences in $\mathrm{pH}$ partly reflects differences in mineralogy between the facies or lithologies of the Chickies Quartzite. Dissolution of silicate minerals is an acid-neutralizing process that raises the $\mathrm{pH}$ of ground water. Silicate minerals are more abundant in the feldspathic arenites and wackes than in the quartz arenites and conglomerates of the Chickies Quartzite described by Hyde (1971). Elevated $\mathrm{Ra}$ commonly is found in the most acidic ground water in the quartzite and conglomerate lithc'ogies (quartz arenite and conglomerate facies), and is less commonly detected in the less acidic ground water in feldspathic arenites of the quartzite lithology. Elevated Ra was not detected in the water in the slate lithology that has the least acidic (most neutral) $\mathrm{pH}$ of the Chickies Quartzite aquifer lithologies.

The spatial distribution of elevated $\mathrm{Ra}$ in ground water generally corresponds to the distribution of lithologies. The quartz arenite and conglomerate facies crop out in the central $\varepsilon$ nd western areas, feldspathic arenites and wackes in the south-central and eastern areas, and th: slate in the south-central area of the Chickies Quartzite, southeastern Pennsylvania (Hyde, 1971; Stose and Stose, 1944). Lithology can be used as a predictor of elevated Ra in ground water. Elevated Ra-228 in ground water has been predicted for arkosic sandstone and sandstone aquifers with high TDS concentrations in the eastern Piedmont (Hess and others, 1985; Michel, 1988). The Chickies Quartzite was classified as arkosic by Engelder (1976).

Ground water in the Chickies Quartzite contains Ra-228 activities that exceed Ra-226 activities. The Ra-228 and Ra-226 activities in ground water indicate a relatively greater abur dance of Th than $U$ in the aquifer. Geologic controls on the distribution of Ra-226 and Ra-228 in the ground water of the Chickies Quartzite may include differences in mineral phases for $U$ and $T h$ in the rocks. The Ra-228/Ra-226 activity ratios are greater in the ground water than the rocks, suggesting preferential dissolution or desorption of Ra-228 from Th-bearing host minerals relative to the release of Ra-226 from U-bearing minerals, or more Th-enrichment relative to $U$ in the rocks than was detected in this study.

The hydrologic setting of the Chickies Quartzite, a ridge-forming, water-table aquifer, also is a control on ground-water chemistry and Ra. From the transect data, it appears that water drilled on ridge crests contains the greatest measured activities of Ra. Ridge crest wells are recharged directly from acidic precipitation. Wells on slopes are supplied from direct acidic recharge that has undorgone little chemical evolution and by ground water that is more chemically evolved and has increased $\mathrm{pH}$ through weathering of silicate minerals and other reactions. $\mathrm{Ra}$ is leached in acidic ground water from aquifer minerals beneath the ridge crests and is transported downgradient where Ra sorl-s to mineral surfaces in contact with waters that are less acidic than upgradient. The quartzite litl ology appears to be more resistant to erosion than the conglomerate lithology of the Chickies Quartzite, because it commonly underlies hilltops where recharge occurs; in this recharge area, ground water chemical evolution may be least advanced (lowest $\mathrm{pH}$ ) because the ground-water is nearest the origin of its flow path and because of the sparsity of easily dissolved silicate minerals in the quartzite. lithology. 
Rn-222 in ground water, because of its short half-life, directly reflects the Ra-226 and U content of the aquifer materials for aquifers with similar porosity, permeability and $\mathrm{Rn-222}$ emanation rates. The hydrologic properties of the conglomerate, quartzite and slate lithologies of the Chickies Quartzite appear to be similar, as determined from well characteristics. However, the conglomerate may contain more $U$ than does the quartzite or the slate, and therefore, has ground water with the maximum Rn-222 activities of the Chickies Quartzite lithologies.

If transport of $\mathrm{Ra}$ from ridge crest to slope occurs, then elevated Rn-222 activities could be expected in ground water from wells on slopes. The transects show that maximum Rn-222 activities are in water from wells on slopes and near the Chickies Quartzite-crystalline rock contact, which partly reflects the higher $U$ content in these rocks. However, $R n-222$ activities are also commonly elevated in water from wells on slopes in the upper section of the quartzite, suggesting that $\mathrm{Ra}$ is retained on aquifer materials rather than mobile in ground water beneath slopes. No significant transport of Ra or Rn-222 into units adjacent to the Chickies was found.

\section{Removal of Radium and Radon From Water Supplies}

Elevated Ra activities in ground water of the Chickies Quartzite could pose a health risk to users. Alternative water supplies or treatment of water are necessary if activities exceed the USEPA MCL for $\mathrm{Ra}$ in drinking water. Zapecza and Szabo (1986) summarize water treatment for Ra, $\mathrm{Rn}$, and $U$, and describe a number of methods to reduce or eliminate those constituents in water. The USE PA has documented procedures for removing of Ra from community water supplies (U.S. Environmental Protection Agency, 1983; Mangelson, 1988; Valentine and others, 1988)-procedures that may be applicable to the few public supply wells in the Chickies Quartzite.

Treatment of water containing dissolved or suspended $\mathrm{Ra}$ and $\mathrm{Rn}$ could result in the concentration of $\mathrm{Ra}, \mathrm{Rn}$, and decay products in filters, ion-exchange columns, treatment tanks, or waste effluent discharged during treatment processes. Safe disposal of radioactive waste effluent or treatment materials is a consideration in selecting a treatment process. 


\section{SUMMARY}

The Chickies Quartzite is a minor water-table aquifer in southeastern Pennsylvania. It is recharged primarily by precipitation, and ground water is soft, dilute, and acidic. The Chickier Quartzite is Lower Cambrian in age and consists of a basal conglomerate, quartzite, and slate. It forms narrow ridges and crops out discontinuously over $112 \mathrm{mi}^{2}$ in the Piedmont Physiographi Province.

Combined activities of radium-226 (Ra-226) and radon-228 (Ra-228) greater than $5 \mathrm{pCi} /$. (picocuries per liter) were detected in water samples from 47 percent of 160 wells penetrating the Chickies Quartzite. Elevated Ra activities were detected throughout the formation. Activities up to $41 \mathrm{pCi} / \mathrm{L}$ for $\mathrm{Ra}-226,160 \mathrm{pCi} / \mathrm{L}$ for $\mathrm{Ra}-228$, and $32,300 \mathrm{pCi} / \mathrm{L}$ for radon-222 (Rn-222) were meas'ured. Ra-228 activity exceeded Ra-226 activity in most ground-water samples. The median Ra-228/Ha-226 activity ratio was 2.4 for ground-water samples from 100 wells.

Nonparametric Spearman rho correlations between $\mathrm{Ra}$ activities and chemical constituer ${ }^{\prime} s$ and properties show that low $\mathrm{pH}$ and high dissolved organic carbon (DOC) correlate most strongly with elevated $\mathrm{Ra} . \mathrm{pH}$ is the strongest control on $\mathrm{Ra}$ mobility. DOC and constituents, such as sulfate ( $\left.\mathrm{SO}_{4}\right)$, that correlated positively with elevated $\mathrm{Ra}$ may enhance $\mathrm{Ra}$ mobility in low $\mathrm{pH}$ waters. $\mathrm{Rn}-22 \mathrm{~s}$. activity does not correlate with its parent isotope, Ra-226, in ground water. Rn-222 correlates inversely with $\mathrm{SO}_{4}$.

The magnitudes of $\mathrm{Ra}-226, \mathrm{Ra}-228$, and $\mathrm{Rn}-222$ activities differ in the ground water from the three lithologies - conglomerate, quartzite, and slate - of the Chickies Quartzite, reflecting variable geochemical controls on solubility, adsorption, and varying uranium (U) and thorium (Th) content. Ra-226 and Ra-228 activities are significantly greater in ground water in the conglomerate and quartzite than in the slate. Ground water in the conglomerate and quartzite is more acidic (median $\mathrm{pH}$ of 5.0 and 5.2, respectively) than ground water in the slate (median $\mathrm{pH}$ of 6.4). Rn-222 activity in ground water is significantly greater in the conglomerate than ground water in the slate and quartzite. Median Rn-222 activity in ground water generally increases progressively from the slate to the quartzite to the conglomerate, suggesting that the $U$ content of the solid phase may increas from the slate to the quartzite to the conglomerate, although other controls on $\mathrm{Rn}-222$, such as aquifer porosity and Rn-222 emanation rates, also are important.

$\mathrm{Ra}$ activity in ground water is related to $\mathrm{U}$ and Th sources in the aquifer and to a geochemical environment that promotes $\mathrm{Ra}$ mobility. $\mathrm{Rn}-222$ activity is related to $\mathrm{U}$ and Ra-226 sources in the aquifer. Variable distribution of $U$ and $T h$ within the conglomerate and quartzite is indicated ky natural-gamma-ray logs. $U$ and Th concentrations in rock samples were similar to those reported for average shales and sandstones. The conglomerate contains zones of Th and U enrichment. Ra-228/ Ra-226 activity ratios are greater in ground water than calculated Th-232/U-238 ratios in rock samples of the quartzite and conglomerate, suggesting preferential leaching of Ra-228 from aquifer solids.

Ra-228, Ra-226, and Rn-222 activities differ locally and temporally. Temporal variability appears to be seasonal. $\mathrm{Ra}$ activities commonly are elevated in water from wells on ridge crest. . $\mathrm{Rn}-222$ activities commonly are elevated in water from wells on slopes and wells near the contact between the Chickies Quartzite and underlying crystalline rock. 


\section{REFERENCES CITED}

Aaron, J.M., 1969, Petrology and origin of the Hardyston Quartzite (Lower Cambrian) in eastern Pennsylvania and western New Jersey in Geology of selected areas in New Jersey and easte "n Pennsylvania: New Brunswick, N.J., Rutgers University Press, p. 21-34.

Adams, J.K, and Goodwin, P.W., 1975, The Chickies Quartzite and some tectonic implications: Proceedings of the Pennsylvania Academy of Science, v. 49, p. 165-167.

American Public Health Association, American Water Works Association, and Water Pollution Control Federation, 1975, Standard methods for the examination of water and wastewater: Washington, D.C., 1193 p.

Ames, L.L., and Rai, Dhanpat, 1978, Radionuclide interactions with rock and soil media, Volume I: U.S. Environmental Protection Agency, EPA 520/6/78-007-A, August 1978.

Ames, L.L., McGarrah, J.E., and Walker, B.A., 1983a, Sorption of trace constituents from aqueous solutions onto secondary minerals. II Radium: Clays and Clay Minerals, v. 31, no. 5, p. 335-342.

Ames, L.L., McGarrah, J.E., and Walker, B.A., 1983b, Sorption of uranium and radium by biotite, muscovite, and phlogopite: Clays and Clay Minerals, v. 31, no. 5, p. 343-351.

Ames, L.L., McGarrah, J.E., Walker, B.A., and Salter, P.F., 1983, Uranium and radium sorption or amorphous ferric oxyhydroxide: Chemical Geology, v. 40, p. 135-148.

Bascom, Florence, Clark, W.B., Darton, N.H., Kummel, H.B., Salisbury, R.D., Miller, B.L., and Knapp, G.N., 1909, Philadelphia Folio, Pennsylvania-New Jersey-Delaware: U.S. Geological Surve! Atlas of the United States Folio 162, 23 p.

Bascom, Florence, and Stose, G.W., 1938, Geology and mineral resources of the Honeybrook and Phoenixville quadrangles, Pennsylvania: U.S. Geological Survey Bulletin 891, 145 p.

Berg, T.M., and Dodge, C.M., eds., 1981, Atlas of preliminary geologic quadrangle maps of Pennsylvania: Pennsylvania Geological Survey, 4th ser., Map 61, 636 p., scale 1:62,500.

Berg, T.M., and Edmunds, W.E., Geyer, A.R., Glover, A.D., Hoskins, D.M., MacLachlan, D.B., Root : S.I., Sevon, W.D., and Socolow, A.W., compilers, 1980, Geologic map of Pennsylvania, 2nd ed.: Pennsylvania Geological Survey, 4th ser., Map 1, scale 1:250,000.

Berg, T.M., McInerney, M.K. Way, J.H., and MacLachlan, D.B., 1986, Stratigraphic correlation chart of Pennsylvania: Pennsylvania Geological Survey General Geology Report 75, 1 sheet.

Berkheiser, S.W., 1985, High-purity silica occurrences in Pennsylvania: Pennsylvania Geological Survey, 4th ser., Mineral Resource Report 88, 67 p.

Campbell, Gregory, and Skillings, J.H., 1985, Nonparametric stepwise multiple comparison procedures: Journal of American Statistics Association, v. 80, p. 998-1003.

Cecil, L.D., 1989, Map showing radium concentrations in ground water of the Chickies Formation. southeastern Pennsylvania, 1986-87: U.S. Geological Survey Open-File Report 87-232, scale $1: 250,000,1$ sheet.

Cecil, L.D., Senior, L.A., and Vogel, K.L., 1991, Radium-226, radium-228, and radon-222 in ground water of the Chickies Quartzite, southeastern Pennsylvania in Gundersen, L.C.S., and Wanty, R.B., eds., Field studies of radon in rocks, soils, and water: U.S. Geological Survey Bulletin 1971, p. 267-277.

Cecil, L.D., Smith, R.C., II, Reilly, M.A., and Rose, A.W., 1987, Radium-228 and radium-226 in the ground water of the Chickies Formation, southeastern Pennsylvania, in Graves, Barbara, ed., Radon, radium and other radioactivity in ground water: Chelsea, Mich., Lewis Publishers, p. 437-447. 
REFERENCES CITED--Continued

Chatham, J.R., Wanty, R.B., and Langmuir, Donald, 1981, Groundwater prospecting sandstone-type uranium deposits: The merits of mineral-solution equilibria versus single element tracemethods: Grand Junction, Co., U.S. Department of Energy Report GJO 79-360E, 197 p.

Conover, W.L., 1980, Practical non-parametric statistics (2nd ed.): New York, John Wiley and Sons, $493 \mathrm{p}$.

Cothern, C.R., 1987, Development of regulations for radionuclides in drinking water in Graves . Barbara, ed., Radon, radium, and other radioactivity in ground water: Chelsea, Mich., Lewis Publishers, p. 1-11.

Dickson, B.L., 1985, Radium isotopes in saline seepages, south-western Yilgarn, Western Australia: Geochimica Cosmochimica Acta, v. 49, p. 361-368.

Dryden, A.L., and Dryden, Clarissa, 1964, Source-rock heavy minerals of the Pennsylvania area: Bryn Mawr, Pennsylvania.

Durrance, E.M., 1986, Radioactivity in geology, principles and applications: Chichester, England, Ellis Horwood Ltd., 441 p.

Engelder, P.R., 1976, The interrelationships between friability and other measured variables in the Chickies Formation: State College, Pa., Pennsylvania State University, unpublished M.S. thesis, $163 \mathrm{p}$.

Fishman, M.J., and Friedman, L.C., eds., 1989, Methods for determination of organic substances in water and fluvial sediments: U.S. Geological Survey Techniques of Water-Resources Investigations, book 5, chap. A1, 545 p.

Freeze, R.A., and Cherry, J.A., 1979, Groundwater: Englewood Cliffs, New Jersey, Prentice-Hall, Inc., $604 \mathrm{p}$.

Friedlander, Gerhart, Kennedy, J.W., Macias, E.S., and Miller, J.M., 1981, Nuclear and radiochemistry: New York, John Wiley and Sons, $684 \mathrm{p}$.

Frondel, J.W., Fleischer, Michael, and Jones, R.S., 1967, Glossary of uranium- and thorium-bearing minerals: U.S. Geological Survey Bulletin 1250, 69 p.

Goodwin, P.W., and Anderson, E.J., 1974, Associated physical and biogenic structures in environmental subdivision of a Cambrian tidal sand body: Journal of Geology, v. 82, p. 779-794.

Helsel, D.R., 1987, Advantages of nonparametric procedures for analysis of water quality data: Hydrological Sciences Journal, v. 32, no. 2, p. 179-190.

Hem, J.D., 1986, Study and interpretation of the chemical characteristics of natural water: U.S. Geological Survey Water-Supply Paper 2254, 264 p.

Hess, C.T., Michel, Jacqueline, Horton, T.R., and Prichard, H.M., 1985, The occurrence of radioactivity in public water supplies in the United States: Health Physics, v. 48, p. 553-586.

Hyde, R.S., 1971, Petrology and origin of the late Precambrian or early Cambrian Chickies Quartzite of southeastern Pennsylvania: Philadelphia, Pa., Temple University, unpublished M.A. thesis, $84 \mathrm{p}$.

Iman, R.L., and Conover, W.J., 1983, A modern approach to statistics: New York, John Wiley and Sons, $497 \mathrm{p}$.

Keys, W.S., 1989, Borehole geophysics applied to ground-water investigations: Dublin, Ohio, National Water Well Association, 313 p.

78 WATER-RESOURCES INVESTIGATIONS REPORT $92-4088$ 


\section{REFERENCES CITED--Continued}

King, P.T., Michel, Jacqueline, and Moore, W.S., 1982, Ground water geochemistry of 228Ra, 226Ra, and 222Rn: Geochimica et Cosmochimica Acta, v. 46, p. 1173-1182.

Knopf, E.B., and Jonas, A.I., 1929, Geology of the McCalls Ferry-Quarryville District, Pennsylvan'a: U.S. Geological Survey Bulletin 799, 156 p.

Langmuir, Donald, 1978, Uranium solution-mineral equilibria at low temperatures with applications to sedimentary ore deposits, in Uranium Deposits, Their Mineralogy and Origin: Toronto, Canada, University of Toronto Press, Mineralogical Association of Canada Short Course Handbook.

Langmuir, Donald, and Herman, J., 1980, The mobility of thorium in natural waters at low temperatures: Geochemica et Cosmochimica Acta, v. 44, p. 1753-1766.

Langmuir, Donald, and Riese, A.C., 1985, The thermodynamic properties of radium: Geochemica et Cosmochimica Acta, v. 49, p. 1593-1601.

Lasaga, A.C., 1984, Chemical kinetics of water-rock interactions: Journal of Geophysical Researcl. v. 89 , no. B6, p. $4009-4025$.

Leenheer, J.A., Malcom, R.L., McKinley, P.W., and Eccles, L.A., 1974, Occurrence of dissolved organic carbon in selected ground-water samples in the United States: U.S. Geological Survey Journal of Research, v. 2, p. 361-369.

Loomis, D.P., 1987, Radon-222 concentration and aquifer lithology in North Carolina: Ground Water Monitoring Review, v. 7, no. 2, p. 33-39.

Lyttle, P.T., and Epstein, J.B., 1987, Geologic map of the Newark $1^{\circ} \times 2^{\circ}$ quadrangle, New Jersey, Pennsylvania, and New York: U.S. Geological Survey Miscellaneous Investigation I-1715, sc $>$ le $1: 250,000,2$ sheets.

Mangelson, K.A., 1988, Radium removal for a small community water-supply system: U.S. Environmental Protection Agency, Project Summary, EPA/600/S2-88/039, 6 p.

Mason, Brian, 1958, Principles of geochemistry (2nd ed.): New York, John Wiley and Sons, Inc., $310 \mathrm{p}$.

McGlade, W.G., Geyer, A.R., and Wilshusen, J.P., 1972, Engineering characteristics of the rocks of Pennsylvania: Pennsylvania Geological Survey, 4th ser., Environmental Geology Report 1, 200 p.

Michel, Jacqueline, 1988, Relationship of radium and radon with geological formations (abstract): Washington, D.C., American Chemical Society Division of Environmental Chemistry, Preprints of Papers presented at the 196th ACS meeting, p. 159-161.

Michel, Jacqueline, Moore, W.S., and Gardner, L.R., 1978, Mobilization of uranium, thorium, and radium during vaporization [abstract]: EOS, American Geophysical Union, v. 5, p. 1224.

Murphy, J.S., 1973, An interpretation of a Baltimore gneiss/Chickies Quartzite contact in the Philadelphia area: Philadelphia, Pa., Temple University, unpublished M.A. thesis, 75 p.

Osmond, J.K., and Lowart, J.B., 1976, The theory and uses of natural uranium isotopic variations in hydrology: Atomic Energy Review, v. 14, no. 4, p. 621-679. 


\section{REFERENCES CITED--Continued}

Pettijohn, F.J., 1963, Chemical composition of sandstones - excluding carbonate and volcanic sands, in Fleischer, Michael, ed., Data of geochemistry: U.S. Geological Survey Professional Paper 440-S, 19 p.

Poth, C.W., 1968, Hydrology of the metamorphic and igneous rocks of central Chester County, Pennsylvania: Pennsylvania Geological Survey, 4th ser., Water Resources Report 25, 84 p.

Pritchard, H.M., and Gesell, T.F., 1977, Rapid measurements of $222 R n$ concentrations in water with a commercial liquid scintillation counter: Health Physics, v. 33, p. 577-581.

Riese, A.C., 1982, Adsorption of radium and thorium onto quartz and kaolinite: a comparison of solution surface equilibria models: Golden, Colo., Colorado School of Mines, unpublished Ph.D. dissertation, $292 \mathrm{p}$.

Rogers, H.D., 1858, The geology of Pennsylvania: Philadelphia, J.B. Lippincott and Co.

Schubert, A.J., Russell, E.R., and Myers, L.S., 1950, Dissociation constants of radium organic acid complexes measured by ion exchange: Journal Biology and Chemistry, v. 185, p. 387-39?.

Smith, R.C., III, 1974, Uranium in the Hardyston Formation: Pennsylvania Geology, v. 5, no. E. p. 1112.

----1975, Thorium-uranium occurrence in Hardyston Formation: Pennsylvania Geology, v. 6, ro. 3, p. 9.

Sloto, R.A., 1989, Selected ground-water data, Chester County, Pennsylvania: U.S. Geological Survey Water-Resources Investigations 87-217, 198 p.

Stose, A.I., and Stose, G.W., 1944, Geology of the Hanover-York District, Pennsylvania: U.S. Geological Survey Professional Paper 204, 84 p.

Stose, G.W., and Jonas, A.I., 1939, Geology and mineral resources of York County, Pennsylvania: Pennsylvania Geological Survey, 4th ser., County Report 67, 199 p.

Stumm, Werner, and Morgan, J.J., 1970, Aquatic chemistry: An introduction emphasizing chemical equilibria in natural waters: New York, John Wiley and Sons, Inc., 583 p.

Tanner, A.B., 1964, Physical and chemical controls on distribution of radium-226 and radon-22.2 in ground water near Great Salt Lake, Utah, in Adams, J.A.S. and Lowder, W.M., eds., The natural radiation environment: Chicago, Ill., University of Chicago Press, p. 253-278.

Thatcher, L.L., Janzer, V.J., and Edwards, K.W., 1977, Methods for determination of radioactive substances in water and fluvial sediments: U.S. Geological Survey Techniques of WaterResource Investigations, book 5, chap. A5, $95 \mathrm{p}$.

Thurman, E.M., 1985, Organic geochemistry of natural waters: Dordrecht, the Netherlands, Martnus Nijoff/Dr. W. Junk Publishers, 497 p.

Tole, M.P., 1979, The uranium content of zircons from the Catskill Formation, eastern Pennsyl-rania: State College, Pa., Pennsylvania State University, unpub. Masters Thesis, 117 p.

Trainer, F.W., 1988, Plutonic and metamorphic rocks, in Back, William, Rosenshein, J.S., and S' $: a b e r$, P.R., eds., Hydrogeology: Geological Society of America, Geology of North America, v. 2, p. 367380.

U.S. Environmental Protection Agency, 1978, Radon in water sampling program: Office of Drinking Water, EPA/EERF - Manual-78-1, 11 p.

-----1981, Radioactivity in drinking water: EPA 57019-81-002. 


\section{REFERENCES CITED--Continued}

----1983, Radionuclide removal for small public water systems: Office of Drinking Water, EPA 57C/083-010.

----1986, Maximum contaminant levels (subpart B of part 141, National interim primary drinkingwater regulations): U.S. Code of Federal Regulations, Title 40, Parts 100 to 149, revised as of July 1, 1986, p. 527.

Valentine, R.L., Splinter, R.C., Mulholland, T.S., Baker, J.M., Nogal, T.M., and Horng, Jao-Jia, 19ع8, A study of possible economical ways of removing radium from drinking water: U.S. Environmental Protection Agency Project Summary EPA/600/S2-88/009, 10 p.

Willard, Bradford, Freedman, Jacob, McLaughlin, D.B., Ryan, J.D., Wherry, E.T., Peltier, L.C., and Gault, H.R., 1959, Geology and mineral resources of Bucks County, Pennsylvania: Pennsylvania Geological Survey, 4th ser., County Report 9, 243 p.

Wilshusen, J.P., 1979, Environmental geology of the greater York area, York County, Pennsylvania: Pennsylvania Geological Survey, 4th ser., Environmental Geology Report 6, 2 sheets.

Wood, W.W., 1976, Guidelines for collection and field analysis of ground-water samples for selected unstable constituents: U.S. Geological Survey Techniques of Water-Resources Investigation*. book 1, chap. D2, 24 p.

Zapecza, O.S., and Szabo, Zoltan, 1986, Natural radioactivity in ground water - a review, in Moody, D.W., Carr, Jerry, Chase, E.B., and Paulson, R.W., compilers, National Water Summary: U.S. Geological Survey Water-Supply Paper 2325, p. 50-57. 


\section{GLOSSARY}

Activity.-Number of atoms of a radioactive element multiplied by the decay constant of the element.

Alpha decay.--The radioactive decay of an unstable isotope during which an alpha particle is emitted and the atomic number is decreased by two.

Alpha particle.--Particle composed of two protons and two neutrons (helium nucleus).

Beta decay.-The radioactive decay of an unstable isotope during which a beta particle is emitted and the atomic number is increased or decreased by one.

Beta particle.-- An electron (or positron) that is derived from the transformation of a neutron to proton (or proton to neutron).

Curie.--Unit of measure of radioactivity based on the decay rate of Ra-226 that has a half-life of 1,620 years; 1 gram of Ra-226 generates 1 Curie.

Decay constant.-- Lambda $=\underline{\ln (2)}$, where lambda is the decay constant and $t_{1 / 2}$ is the half-life. $\mathrm{t}_{1 / 2}$

Gamma ray.--High energy electromagnetic radiation emitted spontaneously in some radioactive decay processes.

Gross-alpha and gross-beta activity.--The total amount of alpha- or beta-particle activity detected from all radionuclides present in a sample. Gross-alpha and beta activities are relative measurements that do not identify specific radionuclides, and that depend upon the counter efficiency, self-absorption of activity by the solids, counting time, energy of alpha ard beta particles, in growth of daughter products, and counter calibration standards. For gross-beta activity, the standard commonly is Cs-137; for gross alpha, the standard may be uranium of natural isotopic composition or Am-241. In a water sample, the gross-alpha and beta activity of the solid residue remaining after evaporation is counted.

Half-life.-- The time required for an amount of a radioactive element to decay to one half that amount.

Isotopes.--Atoms with the same number of protons but different number of neutrons (elernents with different atomic weights).

Picocurie.-- $10^{-12}$ Curies is equivalent to $3.7 \times 10^{-2}$ nuclear disintegrations per second or ahout 2.2 nuclear disintegrations per minute.

Radionuclide.--A radioactive species of atom characterized by the number of protons and neutrons in its nucleus. 
USGS well or spring number: Springs are designated by the prefix, SP; all other numbers refer to wells.

Township or borough: Name refers to township unless noted as Boro for Borough.

Driller license number: 0032, William W. Reichart; 0110, Brown Bros. Drilling Inc.; 0111, Anthony Dominiani Jr.; 0154, Leroy Myers; 0188, C.S. Garber and Sons Inc.; 0198, Eichelberger Well Drilling; 0211, Weldo W. Funt; 0248, Thomas G. Keyes; 0249, Ridpath and Potter Company Inc.; 0274, H.K. Honberger and Son : 0297, Artesian Well Drilling Co.; 0308, Petersheim Bros.; 0317, Walter Knies; 0356, A.C. Reider and Snn, Inc.; 0383, Young Bros.; 0384, E.J. Myers and Sons; 0399, John O'Donnell and Son; 0514, F.L. Bollingem and Sons; 0741, James P. Kohler; 0904, Brookover Well Drilling Co.; 1083, Kenneth L. Madron; 1258, Floyd R. Sensenig; 1290, B.L. Myers; 1308, Robert E. Matteson; 1365, Alfred G. Gurley; 1381, J and J V'oll Drilling; 1457, Bonnie J. Myers; 1515, John W. Wilwert; 1539, Sensenig and Weaver Well Drilling; 1551, Mays Well Drilling; 1609, Edward Powell Well Drilling; 1628, B.L. Myers Bros. Inc.; 1706, Chapman Construction Inc.

Use of site: $U$, unused; $W$, withdrawal; $O$, observation.

Use of water: $H$, domestic; $I$, irrigation; $P$, public supply; $U$, unused.

Topographic setting: H, hilltop; S, slope; V, valley; W, upland draw.

Aquifer codes: 367CNSG, Conestoga Limestone; 377LDGR, Ledger Dolomite; 377VNTG, Vintage Dolomite; 377ANTM, Antietam Quartzite; 377HRPR, Harpers Phyllite; 377CCKS, Chickies Quartzite; 377HRDS. Hardyston Quartzite; 400FLCGP, Felsic gneiss, granulite facies; 400FMFG, Felsic and mafic gneiss; 400FCIGA, Felsic and intermediate gneiss, amphibolite facies; 400BMFGA, Banded mafic gneiss, amphibolite facies; 400FLCGG, Felsic gneiss, granulite facies; 000GBBR, Gabbro and gabbroic gneiss.

Altitude of land surface is estimated from topographic maps. Datum is National Geodetic Vertical Datum of 1929.

Water level is in feet below land surface. 


\begin{tabular}{|c|c|c|c|c|c|c|c|c|c|c|}
\hline \multirow{2}{*}{$\begin{array}{l}\text { USGS } \\
\text { well } \\
\text { number } \\
\text { or spring }\end{array}$} & \multirow[b]{2}{*}{$\begin{array}{c}\text { Location } \\
\text { Latitude Longitude } \\
\text { (degrees) }\end{array}$} & \multirow[b]{2}{*}{$\begin{array}{l}\text { Township } \\
\text { or } \\
\text { borough }\end{array}$} & \multirow[b]{2}{*}{ Owner } & \multirow[b]{2}{*}{$\begin{array}{l}\text { Driller } \\
\text { license } \\
\text { number }\end{array}$} & \multirow[b]{2}{*}{$\begin{array}{c}\text { Year } \\
\text { drilled }\end{array}$} & \multicolumn{2}{|c|}{ Primafy } & \multirow{2}{*}{$\begin{array}{l}\text { Altitude } \\
\text { of land } \\
\text { surface } \\
\text { (feet) }\end{array}$} & \multirow[b]{2}{*}{$\begin{array}{l}\text { Topo- } \\
\text { graphic } \\
\text { setting }\end{array}$} & \multirow[b]{2}{*}{$\begin{array}{l}\text { Hydro- } \\
\text { geologic } \\
\text { unit }\end{array}$} \\
\hline & & & & & & $\begin{array}{l}\text { Use } \\
\text { of } \\
\text { site }\end{array}$ & $\begin{array}{l}\text { Use } \\
\text { of } \\
\text { water }\end{array}$ & & & \\
\hline BE- 1440 & 4011590754635 & Union & French Creek State Park & -- & -. & $\mathbf{0}$ & $\mathrm{U}$ & 710 & $\mathbf{H}$ & ¿77CCKS \\
\hline BK- 396 & 4008140750034 & L. Southampton & Somerton Springs Pool & 0399 & 1927 & $\mathbf{U}$ & $\mathrm{U}$ & 180 & W & ¿77CCKS \\
\hline 1200 & 4009240745535 & Middletown & Rush, Richard & 0111 & 1980 & $\mathbf{W}$ & $\mathbf{H}$ & 57 & $\mathbf{S}$ & ¿77CCKs \\
\hline 1201 & 4009160745605 & Middletown & Orfe, Francis & 0111 & 1979 & w & $\mathrm{H}$ & 40 & $\mathbf{S}$ & ¿77CCKS \\
\hline 1202 & 4012230744942 & L. Makefield & Ferri, David & 0111 & 1985 & $\mathbf{W}$ & $\mathbf{H}$ & 140 & $\mathbf{S}$ & ¿77CCKS \\
\hline 1227 & $401222 \quad 0745027$ & L. Makefield & Hildebrand, J. & 0111 & 1983 & $\mathbf{w}$ & $\mathbf{H}$ & 182 & $\mathbf{H}$ & 4C?FLCGP \\
\hline 1228 & 4012110745013 & L. Makefield & Groome & -- & -- & $\mathbf{w}$ & H & 170 & $\mathbf{S}$ & $277 \mathrm{CCKS}$ \\
\hline 1288 & 4019200750158 & Buckingham & Barford, Thomas & -- & 1967 & $\mathbf{w}$ & $\mathbf{H}$ & 410 & $\mathbf{H}$ & 377HRDS \\
\hline SP21 & 4012290744943 & L. Makefied & Ferri, David & -- & - & $\mathbf{U}$ & $\mathbf{U}$ & 140 & $\mathbf{S}$ & ¿77CCKS \\
\hline CH- 293 & 4004220753128 & Tredyffrin & Cedar Hollow Water Assoc & 0297 & 1927 & $\mathbf{w}$ & $\mathbf{P}$ & 340 & $\mathbf{S}$ & ミ77CCKS \\
\hline 333 & 4005040752904 & Schuylkill & Cappelli, P. & 0248 & 1977 & $\mathbf{w}$ & $\mathbf{H}$ & 545 & $\mathbf{S}$ & :77CCKS \\
\hline 417 & $395728 \quad 0755707$ & W. Sadsbury & Simmons, G. & 1539 & 1986 & $\mathbf{W}$ & H & 720 & $\mathbf{H}$ & 377CCKS \\
\hline 418 & $400740 \quad 0755230$ & W. Nantmeal & Roberts, George & 1365 & 1978 & $\mathbf{w}$ & $\mathbf{H}$ & 810 & $\mathbf{H}$ & §77CCKS \\
\hline 427 & 4008370755107 & W. Nantmeal & Filmore, Robert & -- & 1977 & W & $\mathbf{H}$ & 770 & $\mathbf{S}$ & ₹77HRPR \\
\hline 505 & $400535 \quad 0752847$ & Schuylkill & McMaster, G. & -. & -- & $\mathbf{w}$ & $\mathbf{H}$ & 420 & $\mathbf{S}$ & §77CCKS \\
\hline 693 & 4006140754154 & West Vincent & Laloup, Andrew & 0188 & 1973 & $\mathbf{w}$ & $\mathbf{H}$ & 650 & $\mathbf{S}$ & $377 \mathrm{CCKS}$ \\
\hline 703 & 4008540755017 & West Nantmeal & Miller, Jeff & 0904 & 1987 & $\mathbf{w}$ & $\mathrm{H}$ & 718 & $\mathbf{S}$ & ₹77HRPR \\
\hline 945 & 3959180755002 & Valley & Hines, Norman & -- & -- & $\mathbf{w}$ & H & 470 & $\mathbf{S}$ & :77CCKS \\
\hline 992 & $395808 \quad 0755303$ & Sadsbury & Doratt, Shirley & 0154 & 1949 & $\mathbf{w}$ & H & 615 & $\mathbf{S}$ & E77HRPR \\
\hline 1089 & 4009090755038 & Elverson Boro & Fry, Edward & 0308 & 1984 & w & $\mathbf{H}$ & 675 & $\mathbf{S}$ & 377CCKS \\
\hline 1090 & $400108 \quad 0755458$ & West Caln & Funk, Jim & 0904 & 1979 & $\mathbf{W}$ & $\mathbf{H}$ & 800 & $\mathbf{S}$ & 377CCKS \\
\hline 1091 & 4000300755542 & West Caln & Loggins, Lawrence & 0308 & 1975 & $\mathbf{w}$ & H & 878 & $\mathbf{H}$ & 377CCKS \\
\hline 1092 & $400335 \quad 0754905$ & W. Brandywine & Urban, Joe & -- & - & $\mathbf{w}$ & H & 730 & $\mathbf{S}$ & 377CCKS \\
\hline 1093 & 4002250753814 & W. Whiteland & Mattioni, Amberto & 1365 & - & $\mathbf{w}$ & $\mathbf{H}$ & 450 & $\mathbf{S}$ & $377 \mathrm{CCKS}$ \\
\hline 1094 & $400254 \quad 0755313$ & West Caln & Bryan, Joseph & - & 1981 & $\mathbf{W}$ & $\mathbf{H}$ & 916 & $\mathbf{H}$ & $377 \mathrm{CCKS}$ \\
\hline 1095 & 3958170755313 & Sadsbury & Wolf, Lentha & 0319 & 1978 & $\mathbf{W}$ & H & 635 & s & 377CCKS \\
\hline 1096 & $400206 \quad 0755337$ & West Caln & Gregor, Adam & 1308 & 1987 & w & $\mathbf{H}$ & 760 & $\mathbf{S}$ & 377CCKS \\
\hline 1097 & 4002140755551 & West Caln & Batdorf, Vernon & 0319 & 1978 & w & $\mathbf{H}$ & 742 & $\mathbf{H}$ & 377ANTM \\
\hline 1098 & $400246 \quad 0755423$ & West Caln & Supplee, Elam & 0308 & 1977 & W & $\mathbf{H}$ & 885 & $\mathbf{s}$ & 377CCKS \\
\hline 1099 & 4009270754927 & Elverson & Austin, Jeff & - & 1974 & $\mathbf{w}$ & $\mathbf{H}$ & 610 & $\mathbf{S}$ & 40 กFLCGG \\
\hline 1213 & $400224 \quad 0754055$ & Uwchlan & Fetteroft, Ken & 0248 & 1971 & w & $\mathbf{H}$ & 615 & $\mathbf{S}$ & $377 \mathrm{CCKS}$ \\
\hline 1217 & 4002160754056 & Uwchlan & Copp, Karen & 0248 & 1972 & $\mathbf{w}$ & $\mathbf{H}$ & 555 & $\mathbf{S}$ & 377CCKS \\
\hline 1265 & 4007080755506 & Honey Brook & Samuels, F. & 0308 & 1968 & w & H & 910 & $\mathbf{S}$ & 377CCKS \\
\hline 1286 & 4003590755146 & Honey Brook & Blake, Ramous & 0308 & 1968 & w & $\mathbf{U}$ & 760 & $\mathbf{S}$ & $377 \mathrm{CCKS}$ \\
\hline 1296 & 4003380755144 & Honey Brook & Morris, T. & 0308 & 1971 & w & $\mathbf{H}$ & 820 & $\mathbf{S}$ & $377 \mathrm{CCKS}$ \\
\hline 1367 & $400300 \quad 0755237$ & W. Caln & Francis, D. & 0308 & 1972 & $\mathbf{W}$ & $\mathbf{H}$ & 856 & $\mathbf{S}$ & $377 \mathrm{CCKS}$ \\
\hline 1376 & 4000160755211 & West Caln & Ferguson, Charles & 0904 & 1971 & w & $\mathbf{H}$ & 684 & $\mathbf{S}$ & 377CCKS \\
\hline
\end{tabular}




\begin{tabular}{|c|c|c|c|c|c|c|c|c|c|c|c|c|c|}
\hline \multirow[b]{2}{*}{$\begin{array}{l}\text { Depth } \\
\text { of } \\
\text { well } \\
\text { (feet) }\end{array}$} & . & & \multirow[b]{2}{*}{$\begin{array}{c}\text { Depth to } \\
\text { water-bearing } \\
\text { zone(s) } \\
\text { (feet) }\end{array}$} & \multirow[b]{2}{*}{$\begin{array}{l}\text { Water } \\
\text { level } \\
\text { (feet) }\end{array}$} & \multirow[b]{2}{*}{$\begin{array}{c}\text { Date } \\
\text { water } \\
\text { level } \\
\text { measured }\end{array}$} & \multirow[b]{2}{*}{$\begin{array}{l}\text { Reported } \\
\text { yield } \\
\text { (gal/ } \\
\text { min) }\end{array}$} & \multicolumn{3}{|c|}{ Measured vield } & \multicolumn{3}{|c|}{ Eield water quality } & \multirow[b]{2}{*}{$\begin{array}{c}\text { USGS } \\
\text { well } \\
\text { number } \\
\text { or spring }\end{array}$} \\
\hline & Casing & $\begin{array}{l}\text { Diameter } \\
\text { (inches) }\end{array}$ & & & & & $\begin{array}{c}\text { Specific } \\
\text { capacity } \\
{[(\mathrm{gal} /} \\
\mathrm{min}) / \mathrm{ft}]\end{array}$ & $\begin{array}{l}\text { Dis- } \\
\text { charge } \\
\text { (gal/ } \\
\text { min) }\end{array}$ & $\begin{array}{l}\text { Pumping } \\
\text { period } \\
\text { (hours) }\end{array}$ & $\begin{array}{c}\text { Date } \\
\text { measured }\end{array}$ & $\begin{array}{l}\text { Specific } \\
\text { conduc- } \\
\text { tance } \\
(\mu \mathrm{S} / \mathrm{cm})\end{array}$ & $\begin{array}{c}\text { pH } \\
\text { (stan- } \\
\text { dard } \\
\text { units) }\end{array}$ & \\
\hline- & - & - & - & -- & - & -- & - & -- & -- & $12-22-86$ & 145 & 6.3 & 1440-BE \\
\hline 318 & - & - & -- & - & $07-07-47$ &.- & 1.7 & 100 & 8.0 & $12-21-86$ & 251 & 6.2 & 396-BK \\
\hline 125 & 52 & 6 & $60 / 115$ & 26.10 & $12-21-86$ & - & .50 & 10 & 2 & $12-21-86$ & 275 & 5.8 & 1200 \\
\hline 40 & 37 & 6 & 32 & 10.00 & 04-08-79 & - & 2.5 & 25 & 2 & $12-31-86$ & 298 & 5.0 & 1201 \\
\hline 165 & 30 & 6 & $15 / 35 / 50$ & 1.30 & $12-31-86$ & - & .06 & 8 & .3 & $12-31-86$ & 58 & 5.4 & 1202 \\
\hline 165 & 63 & 6 & $80 / 118 / 142$ & 14.20 & $06-22-87$ & -- & .56 & 25 & 2 & $06-22-87$ & 145 & 6.6 & 1227 \\
\hline -- & -- & - & - & - & -- & - & - & - & -- & $06-27-87$ & 343 & 6.0 & 1228 \\
\hline 109 & - & -- & $86 / 108$ & 74.40 & $09-03-88$ & -- & .34 & 12 & 4 & $09-03-88$ & 92 & 5.1 & 1288 \\
\hline- & - & - & .- & -. & -- & - & - & - & -- & $05-27-87$ & 105 & 4.9 & SP21 \\
\hline 90 & - & - & - & 19.00 & $04-01-27$ & $-\cdot$ & .55 & 96 & - & $11-13-86$ & 340 & 6.4 & 293-CH \\
\hline 265 & 48 & 6 & -. & 50.40 & $11-15-86$ & -. & .01 & 4 & 1 & $11-15-86$ & 189 & 4.8 & 333 \\
\hline 160 & 35 & 6 & - & 50.60 & $11-24-86$ & 20 & -- & - & - & $11-24-86$ & 77 & 5.2 & 417 \\
\hline 140 & 82 & 6 & $100 / 135$ & 93.60 & $12-05-86$ & 15 & - & - & 1 & $12-05-86$ & 41 & 4.9 & 418 \\
\hline- & -- & - & - & - & - & - & - & -- & - & $12-05-86$ & 19 & 5.2 & 427 \\
\hline- & -- & - & - & 45.50 & $05-08-87$ & - & - & - & - & $05-08-87$ & 125 & 5.9 & 505 \\
\hline 145 & 83 & 6 & -- & 60.00 & $11-07-73$ & - & .70 & 60 & - & $05-29-87$ & 64 & 5.9 & 693 \\
\hline 208 & 45 & 6 & 80 & 82.30 & $06-05-87$ & - & .01 & 2 & 2 & $06-05-87$ & 160 & 6.1 & 703 \\
\hline 80 & - & - & - & 36.10 & $11-14-63$ & - & .. & - & - & $11-13-86$ & 93 & 5.5 & 945 \\
\hline 125 & 120 & 6 & $60 / 85 / 125$ & 8.00 & $05-27-64$ & 30 & .. & - & - & $05-27-64$ & 200 & 5.6 & 992 \\
\hline 140 & 120 & 4 & $115 / 120$ & 90.90 & $06-12-87$ & - & 1 & 40 & .5 & $06-12-87$ & 145 & 5.3 & 1089 \\
\hline 63 & 21 & 6 & 49 & 29.00 & $06-17-87$ & - & .99 & 20 & - & $06-17-87$ & 76 & 4.7 & 1090 \\
\hline 153 & 39 & 6 & - & 45.00 & $12-11-75$ & -. & .25 & 5 & - & $06-18-87$ & 39 & 4.8 & 1091 \\
\hline 95 & - & - & -- & 40.00 & $06-23-87$ & 12 & - & - & .. & $06-23-87$ & 62 & 5.0 & 1092 \\
\hline 150 & 43 & 6 & $118 / 126$ & 59.80 & $06-26-87$ & - & .33 & 5 & .7 & $06-26-87$ & 193 & 5.6 & 1093 \\
\hline 155 & - & - & - & 70.00 & $06-26-87$ & 22 & -. & - & - & $06-26-87$ & 10 & 5.2 & 1094 \\
\hline 150 & 63 & 6 & $95 / 141$ & -- & - & 10 & -- & - & - & $07-28-87$ & 163 & 4.7 & 1095 \\
\hline 120 & 42 & 6 & $35 / 69$ & 29.90 & $07-29-87$ & 10 & - & -. & - & $07-29-87$ & 15 & 5.0 & 1096 \\
\hline 200 & 21 & 6 & $146 / 188$ & 82.00 & $08-04-87$ & 6 & - & - & - & $08-04-87$ & 121 & 4.9 & 1097 \\
\hline 200 & 40 & 6 & $55 / 150 / 185$ & $\cdots$ & - & $\cdots$ & 1.8 & 9 & - & $08-05-87$ & 70 & 4.7 & 1098 \\
\hline- & - & -- & - & 24.00 & $08-06-87$ & - & - & - & - & $08-08-87$ & 100 & 5.1 & 1099 \\
\hline 70 & 40 & 6 & 53 & 29.00 & $01-01-74$ & - & .44 & 15 & 1.0 & $07-02-87$ & 203 & 5.3 & 1213 \\
\hline 120 & 75 & 6 & 50 & 18.00 & $02-01-74$ & - & .14 & 15 & 1.0 & $06-30-87$ & 114 & 5.6 & 1217 \\
\hline 110 & 86 & 6 & $95 / 102$ & - & -. & 25 & - & - & - & $11-21-86$ & 229 & 4.8 & 1265 \\
\hline 182 & 35 & 6 & $160 / 175 / 182$ & 72.7 & $12-01-86$ & 5 & - & - & - & $12-01-86$ & 200 & 4.6 & 1286 \\
\hline 123 & 40 & 6 & $50 / 65 / 115$ & $\cdots$ & - & 15 & - & -. & - & $09-02-87$ & 118 & 4.8 & 1296 \\
\hline 280 & 63 & 6 & 273 & -- & - & 25 & - & - & - & $08-05-87$ & 70 & 4.5 & 1367 \\
\hline 75 & 21 & 6 & $68 / 71$ & 35.00 & $09-20-71$ & - & .75 & 18 & 2.0 & $09-04-87$ & 131 & 4.8 & 1376 \\
\hline
\end{tabular}


Table 20. Records of wells and springs--Continued

\begin{tabular}{|c|c|c|c|c|c|c|c|c|c|c|}
\hline \multirow{2}{*}{$\begin{array}{l}\text { USGS } \\
\text { well } \\
\text { number } \\
\text { or spring }\end{array}$} & \multirow[b]{2}{*}{ 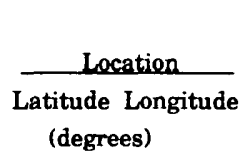 } & \multirow[b]{2}{*}{$\begin{array}{l}\text { Township } \\
\text { or } \\
\text { borough }\end{array}$} & \multirow[b]{2}{*}{ Owner } & \multirow[b]{2}{*}{$\begin{array}{l}\text { Driller } \\
\text { license } \\
\text { number }\end{array}$} & \multirow[b]{2}{*}{$\begin{array}{c}\text { Year } \\
\text { drilled }\end{array}$} & \multicolumn{2}{|c|}{ Primacy } & \multirow{2}{*}{$\begin{array}{l}\text { Altitude } \\
\text { of land } \\
\text { surface } \\
\text { (feet) }\end{array}$} & \multirow[b]{2}{*}{$\begin{array}{l}\text { Topo- } \\
\text { graphic } \\
\text { setting }\end{array}$} & \multirow[b]{2}{*}{$\begin{array}{l}\text { Hydro- } \\
\text { geologic } \\
\text { unit }\end{array}$} \\
\hline & & & & & & $\begin{array}{c}\text { Use } \\
\text { of } \\
\text { site }\end{array}$ & $\begin{array}{c}\text { Use } \\
\text { of } \\
\text { water }\end{array}$ & & & \\
\hline $\mathrm{CH}-1616$ & 4003290753622 & Charlestown & Bacton Hill Church & 0308 & 1973 & $\mathbf{w}$ & $\mathbf{H}$ & 615 & $\mathbf{S}$ & 377CCKS \\
\hline 1617 & 4003380753527 & Charlestown & Moffett, F. & 0248 & 1973 & $\mathbf{w}$ & $\mathbf{H}$ & 680 & $\mathbf{S}$ & 377CCKS \\
\hline 1618 & 4004170753411 & Charlestown & Chalupa, William & 0308 & 1972 & $W$ & $\mathbf{H}$ & 613 & $\mathbf{S}$ & 377CCKS \\
\hline 2113 & $400120 \quad 0754144$ & E. Caln & Northwood Cemetery & 0904 & 1966 & $\mathbf{w}$ & $\mathbf{U}$ & 467 & $\mathbf{S}$ & 377CCKS \\
\hline 2115 & 4000460754440 & Caln & Darlington, Edward & 0904 & 1967 & $w$ & $\mathbf{H}$ & 415 & $\mathbf{S}$ & 400BMFGA \\
\hline 2410 & 4003010755451 & West Caln & Baldwin Clement & 0384 & 1978 & $\mathbf{w}$ & $\mathbf{H}$ & 910 & $\mathbf{H}$ & 377CCKS \\
\hline 2417 & 4001170755415 & West Caln & Snyder, E. & -- & - & $\mathbf{W}$ & $\mathrm{H}$ & 815 & $\mathbf{H}$ & 377CCKS \\
\hline 2418 & $400340 \quad 0755012$ & West Brandywine & Hooper, Robert & .. & 1980 & $\mathbf{W}$ & $\mathbf{H}$ & 770 & $\mathbf{H}$ & $377 \mathrm{CCKS}$ \\
\hline 2828 & $395750 \quad 0755302$ & Sadsbury & Watts, $\mathbf{R}$. & 1083 & 1981 & $\mathbf{w}$ & $\mathbf{H}$ & 496 & $\mathbf{v}$ & $367 \mathrm{CNSG}$ \\
\hline 2847 & $400320 \quad 0753553$ & Charlestown & Magargee, Steven & 0248 & -- & $\mathbf{W}$ & $\mathbf{H}$ & 648 & $\mathbf{s}$ & 377CCKS \\
\hline 2998 & 4006110755438 & Honeybrook & Stoltzfus, John & - & 1963 & $\mathbf{w}$ & $\mathbf{H}$ & 701 & $\mathbf{S}$ & 400FLCGG \\
\hline 3076 & 4002210755304 & West Caln & Warren, William & -- & - & $\mathbf{w}$ & $\mathrm{H}$ & 839 & $\mathbf{S}$ & 377CCKS \\
\hline 3079 & $400454 \quad 0752817$ & Tredyffrin & Linton, Otto & 0248 & 1978 & $\mathbf{W}$ & $\mathbf{H}$ & 350 & $\mathbf{s}$ & 377HRPR \\
\hline 3086 & 4004390753325 & Charlestown & Faggioli, Dorando & 0904 & 1978 & $\mathbf{w}$ & $\mathbf{H}$ & 480 & $\mathbf{S}$ & 400FCIGA \\
\hline 3087 & 4003250753555 & Charlestown & Sorgenfrei, Mal & 1609 & 1983 & $\mathbf{W}$ & $\mathbf{H}$ & 705 & $\mathrm{H}$ & 377CCKS \\
\hline 3088 & 4003050753651 & Charlestown & Wallin, Mark & 1628 & 1986 & $\mathbf{w}$ & $\mathbf{H}$ & 680 & $\mathbf{H}$ & 377CCKS \\
\hline 3089 & 4002220754418 & E. Brandywine & Phipps, Daniel & 0188 & 1975 & $\mathbf{W}$ & $\mathbf{H}$ & 495 & $\mathbf{S}$ & 400FCIGA \\
\hline 3090 & 4002020754419 & E. Brandywine & Hopewell U. Meth. Church & 1457 & 1978 & $\mathbf{W}$ & $\mathbf{H}$ & 418 & $\mathbf{S}$ & 400FCIGA \\
\hline 3091 & 4004190753420 & Charlestown & Rossiter, Barry & 0248 & 1981 & $\mathbf{w}$ & $\mathbf{H}$ & 575 & $\mathbf{S}$ & 377CCKS \\
\hline 3111 & 4003150753540 & E. Whiteland & Wiley, Frank & 0904 & 1982 & $\mathbf{W}$ & $\mathbf{H}$ & 570 & $\mathbf{S}$ & 377CCKS \\
\hline 3112 & $400508 \quad 0752919$ & Schuylkill & Snyder, Marshall & 0248 & 1981 & $\mathbf{W}$ & $\mathbf{H}$ & 610 & $\mathbf{H}$ & 377CCKS \\
\hline 3113 & 4005070752907 & Tredyffrin & Generotti, Bruce & 0248 & 1979 & $\mathbf{w}$ & $\mathbf{H}$ & 438 & $\mathbf{S}$ & 377CCKS \\
\hline 3114 & $400408 \quad 0753415$ & Charlestown & Capetola, E. & 0188 & 1979 & $\mathbf{W}$ & $\mathbf{H}$ & 630 & $\mathbf{H}$ & 377CCKS \\
\hline 3117 & 4001480754301 & E. Brandywine & Chatfield, William & 0317 & 1983 & $\mathbf{w}$ & $\mathbf{H}$ & 495 & $\mathbf{s}$ & 400FCIGA \\
\hline 3122 & 4002060755336 & West Caln & Gregor and Comb & - & 1987 & $\mathbf{W}$ & $\mathbf{H}$ & 755 & $\mathbf{S}$ & 377CCKS \\
\hline 3123 & 4002270755229 & West Caln & Ickes, Larry & - & -- & $\mathbf{W}$ & $\mathbf{H}$ & 783 & $\mathbf{s}$ & 377CCKS \\
\hline 3124 & 4003150755230 & West Caln & Bireley, Craig & - & 1984 & $\mathbf{w}$ & $\mathbf{H}$ & 832 & $\mathbf{H}$ & 377CCKS \\
\hline 3125 & 4002240754327 & E. Brandywine & Arthers, Raymond & 0904 & 1979 & $\mathbf{w}$ & $\mathbf{H}$ & 580 & $\mathbf{H}$ & 377CCKS \\
\hline 3126 & 4002180754240 & E. Brandywine & Clayton, Edward & 0248 & 1979 & $\mathbf{w}$ & $\mathbf{H}$ & 385 & $\mathbf{S}$ & 377CCKS \\
\hline 3127 & 4002320754107 & Uwchlan & Staurowsky, Phillip & 0248 & 1983 & $\mathbf{W}$ & $\mathbf{H}$ & 520 & $\mathbf{s}$ & 377CCKS \\
\hline 3128 & 4004190753358 & Charlestown & Busaglia, Carl & 0904 & 1979 & $\mathbf{w}$ & $\mathbf{H}$ & 645 & $\mathbf{H}$ & 377CCKS \\
\hline 3131 & 4002070755337 & West Caln & Barrage & 0308 & 1987 & $\mathbf{W}$ & $\mathbf{H}$ & 762 & $\mathbf{S}$ & 377CCKS \\
\hline 3132 & 4004180753400 & Charlestown & Persico, Frank & 0904 & 1979 & $\mathbf{W}$ & $\mathbf{H}$ & 645 & $\mathbf{H}$ & 377CCKS \\
\hline 3133 & 4002170755343 & West Caln & Gregor, Lawrence & 0308 & 1987 & $\mathbf{w}$ & $\mathbf{H}$ & 840 & $\mathbf{S}$ & 377CCKS \\
\hline 3135 & 4003580753503 & Charlestown & Hoy, Thomas & 0904 & 1986 & $\mathbf{W}$ & $\mathbf{H}$ & 600 & $\mathbf{S}$ & 377CCKS \\
\hline 3136 & 4003180753526 & E. Whiteland & Turner, Thomas & 0248 & - & $\mathbf{w}$ & $\mathbf{H}$ & 465 & $\mathbf{s}$ & 377HRPR \\
\hline
\end{tabular}




\begin{tabular}{|c|c|c|c|c|c|c|c|c|c|c|c|c|c|}
\hline \multirow[b]{2}{*}{$\begin{array}{l}\text { Depth } \\
\text { of } \\
\text { well } \\
\text { (feet) }\end{array}$} & \multirow{2}{*}{\multicolumn{3}{|c|}{\begin{tabular}{ccc} 
& & Depth to \\
\multicolumn{2}{c}{ Casing } & water-bearing \\
\cline { 1 - 2 } Depth & Diameter & zone(s) \\
(feet) & (inches) & (feet)
\end{tabular}}} & \multirow[b]{2}{*}{$\begin{array}{l}\text { Water } \\
\text { level } \\
\text { (feet) }\end{array}$} & \multirow[b]{2}{*}{$\begin{array}{c}\text { Date } \\
\text { water } \\
\text { level } \\
\text { measured }\end{array}$} & \multirow[b]{2}{*}{$\begin{array}{l}\text { Reported } \\
\text { yield } \\
\text { (gal } \\
\text { min) }\end{array}$} & \multicolumn{3}{|c|}{ Measured vield } & \multicolumn{3}{|c|}{ Field water quality } & \multirow[b]{2}{*}{$\begin{array}{l}\text { USGS } \\
\text { well } \\
\text { number } \\
\text { or spring }\end{array}$} \\
\hline & & & & & & & $\begin{array}{c}\text { Specific } \\
\text { capacity } \\
{[(\mathrm{gaV} V} \\
\mathrm{min}) / \mathrm{ft}]\end{array}$ & $\begin{array}{c}\text { Dig- } \\
\text { charge } \\
\text { (gal/ } \\
\text { min) }\end{array}$ & $\begin{array}{l}\text { Pumping } \\
\text { period } \\
\text { (hours) }\end{array}$ & $\begin{array}{c}\text { Date } \\
\text { measured }\end{array}$ & $\begin{array}{c}\text { Specific } \\
\text { conduc- } \\
\text { tance } \\
(\mu \mathrm{S} / \mathrm{cm})\end{array}$ & $\begin{array}{c}\text { pH } \\
\text { (stan- } \\
\text { dard } \\
\text { units) }\end{array}$ & \\
\hline 130 & 79 & 6 & $86 / 115$ & - & - & 35 & - & - & - & $10-23-87$ & 240 & 5.1 & $1616-\mathrm{CH}$ \\
\hline 194 & 50 & $6 \quad 11$ & $17 / 139 / 158 / 180$ & 30.6 & $06-03-87$ & -- & 0.06 & 6 & 1.0 & $06-03-87$ & 116 & 4.7 & 1617 \\
\hline 240 & 96 & 6 & 240 & -- & -- & 4 & - & -- & - & $05-22-87$ & 164 & 4.6 & 1618 \\
\hline 155 & 35 & 6 & $135 / 148$ & 63.00 & $11-01-66$ & -- & .56 & 32 & 4.0 & $11-10-86$ & 157 & 5.7 & 2113 \\
\hline 137 & 12 & 6 & $70 / 97 / 123$ & 64.00 & $06-01-67$ & - & .15 & 8 & 6.0 & $11-10-86$ & 127 & 6.6 & 2115 \\
\hline 145 & 20 & 6 & $22 / 70$ & 52.90 & $07-24-80$ & 10 & - & -- & - & $11-20-86$ & 139 & 5.8 & 2410 \\
\hline- & - & - & - & - & -- & - & - & - & - & $08-27-80$ & - & 7.1 & 2417 \\
\hline- & - & - & -- & 32.43 & $11-22-86$ & -- & - & - & - & $11-22-86$ & 27 & 5.4 & 2418 \\
\hline 146 & 86 & 6 & $95 / 120$ & 32.95 & $07-29-87$ & 20 & - & - & -- & $07-29-87$ & 677 & 7.0 & 2828 \\
\hline 123 & 89 & 6 & $92 / 101$ & 60.00 & $09-05-87$ & - & .21 & 15 & 1 & $09-05-87$ & 49 & 4.8 & 2847 \\
\hline 73 & - & - & - & - & -- & - & - & - & -- & $07-16-87$ & 340 & 5.4 & 2998 \\
\hline-- & - & - & - & - & - & - & - & - & -- & $07-16-87$ & 160 & 4.8 & 3076 \\
\hline 182 & 146 & 6 & 158 & 61.10 & $07-27-87$ & - & .11 & 12 & 1 & $07-27-87$ & 103 & 6.6 & 3079 \\
\hline 125 & 55 & 6 & $97 / 116$ & 38.60 & $08-07-87$ & - & .56 & 23 & 3 & $08-07-87$ & 175 & 5.6 & 3086 \\
\hline 160 & 21 & 6 & $84 / 95 / 125 / 143$ & 47.00 & $08-13-87$ & - & .13 & 10 & 3 & $08-13-87$ & 82 & 4.3 & 3087 \\
\hline 280 & 168 & 6 & 180 & - & - & 2 & -- & - & -- & $08-13-87$ & 33 & 5.4 & 3088 \\
\hline 210 & 55 & 6 & $100 / 190 / 200$ & 46.20 & $08-12-87$ & -. & .11 & 5 & .5 & $08-12-87$ & 95 & 6.5 & 3089 \\
\hline 170 & 20 & 6 & 30 & 35.30 & $08-12-87$ & 8 & - & - & 1 & $08-12-87$ & 130 & 5.6 & 3090 \\
\hline 100 & 20 & 6 & $37 / 75$ & 50.70 & $08-11-87$ & - & .15 & 10 & 1 & $08-11-87$ & 118 & 4.7 & 3091 \\
\hline 146 & 20 & 6 & 133 & 30.30 & $08-26-87$ & -- & .08 & 7 & 4 & $08-26-87$ & 36 & 4.9 & 3111 \\
\hline 263 & 24 & 6 & 183 & 70.00 & $08-28-87$ & -- & .02 & 4 & 1 & $08-28-87$ & 214 & 4.4 & 3112 \\
\hline 220 & 20 & 6 & 100 & 15.00 & $03-01-79$ & - & .02 & 4 & 1 & $08-28-87$ & 219 & 5.6 & 3113 \\
\hline 248 & 60 & 6 & $136 / 191 / 242$ & 105.00 & $08-29-87$ & - & - & - & -- & $08-29-87$ & - & 4.7 & 3114 \\
\hline 100 & 40 & 6 & $65 / 91$ & -- & -- & 45 & - & - & - & $08-31-87$ & 77 & 5.3 & 3117 \\
\hline 270 & 56 & 6 & $140 / 240 / 265$ & 37.00 & $09-04-87$ & 18 & -. & - & - & $09-04-87$ & 70 & 6.1 & 3122 \\
\hline- & - & - & - & 66.50 & $09-02-87$ & - & - & - & - & $09-02-87$ & 42 & 5.0 & 3123 \\
\hline 185 & 42 & 6 & - & 41.20 & $09-02-87$ & 8 & - & - & - & $09-02-87$ & 38 & 4.6 & 3124 \\
\hline 103 & 44 & 6 & $58 / 85$ & 35.90 & $09-01-87$ & - & .34 & 11 & 4 & $09-01-87$ & 271 & 4.3 & 3125 \\
\hline 100 & 46 & 6 & -- & 49.80 & $09-01-87$ & - & .16 & 8 & 1 & $09-01-87$ & 16 & 5.3 & 3126 \\
\hline 81 & 27 & 6 & $30 / 50$ & 10.00 & $10-00-83$ & 35 & -- & -- & 1 & $09-01-87$ & 165 & 5.3 & 3127 \\
\hline 165 & 40 & 6 & $77 / 156$ & 97.70 & $09-03-87$ & - & .05 & 6 & 4 & $09-03-87$ & 68 & 4.3 & 3128 \\
\hline 155 & 58 & 6 & 110 & 52.00 & $09-04-87$ & 15 & - & - & -- & $09-04-87$ & 16 & 5.2 & 3131 \\
\hline 143 & 21 & 6 & $65 / 132$ & 58.00 & $03-26-79$ & - & .08 & 5 & 4 & $09-03-87$ & 304 & 4.3 & 3132 \\
\hline 155 & 98 & 6 & 100 & 9.95 & $10-21-87$ & - & -. & - & -- & $10-21-87$ & 19 & 4.8 & 3133 \\
\hline 291 & 44 & 6 & $80 / 90$ & 66.80 & $09-05-87$ & - & .08 & 2 & 4 & $09-05-87$ & 152 & 5.1 & 3135 \\
\hline 200 & - & -- & -- & - & .- & -- & -- & - & -. & $09-08-87$ & 150 & 4.9 & 3136 \\
\hline
\end{tabular}


Table 20. Records of wells and springs--Continued

\begin{tabular}{|c|c|c|c|c|c|c|c|c|c|c|}
\hline \multirow{2}{*}{$\begin{array}{l}\text { USGS } \\
\text { well } \\
\text { number } \\
\text { or spring }\end{array}$} & \multirow{2}{*}{\multicolumn{2}{|c|}{$\begin{array}{l}\text { Location } \\
\text { atitude Longitude } \\
\text { (degrees) }\end{array}$}} & \multirow[b]{2}{*}{ Owner } & \multirow[b]{2}{*}{$\begin{array}{l}\text { Driller } \\
\text { license } \\
\text { number }\end{array}$} & \multirow[b]{2}{*}{$\begin{array}{c}\text { Year } \\
\text { drilled }\end{array}$} & \multicolumn{2}{|c|}{ Primary } & \multirow{2}{*}{$\begin{array}{l}\text { Altitude } \\
\text { of land } \\
\text { surface } \\
\text { (feet) }\end{array}$} & \multirow[b]{2}{*}{$\begin{array}{l}\text { Topo- } \\
\text { graphic } \\
\text { setting }\end{array}$} & \multirow[b]{2}{*}{$\begin{array}{l}\text { Hydro- } \\
\text { geologic } \\
\text { unit }\end{array}$} \\
\hline & & & & & & $\begin{array}{c}\text { Use } \\
\text { of } \\
\text { site }\end{array}$ & $\begin{array}{l}\text { Use } \\
\text { of } \\
\text { water }\end{array}$ & & & \\
\hline CH-3160 & 4004040755156 & Honeybrook & Evans, Wayne & 1628 & 1987 & $\mathbf{w}$ & $\mathbf{H}$ & 700 & $\mathbf{s}$ & $377 \mathrm{CCKS}$ \\
\hline 3166 & 4002530755358 & West Caln & McCumsky, Ed & 1628 & 1987 & $\mathbf{W}$ & $\mathbf{H}$ & 935 & $\mathbf{H}$ & $377 \mathrm{CCKS}$ \\
\hline 3168 & 4001090754320 & E. Brandywine & D'Ginto, Roy & 0904 & 1978 & $\mathbf{w}$ & $\mathbf{H}$ & 490 & $\mathbf{S}$ & 377CCKS \\
\hline 3189 & 4002360755440 & West Caln & Myers, Craig & 1308 & 1987 & $\mathbf{W}$ & $\mathbf{H}$ & 863 & $\mathbf{s}$ & 377CCKS \\
\hline 3213 & 4002380755353 & West Caln & Herr & 1308 & 1987 & $\mathbf{W}$ & $\mathbf{H}$ & 917 & $\mathbf{s}$ & 377CCKS \\
\hline 3214 & 4003700755502 & West Caln & Klingensmith, David & 1290 & 1979 & $\mathbf{w}$ & $\mathbf{H}$ & 812 & $\mathbf{S}$ & 377CCKS \\
\hline 3215 & 4003320753615 & Charlestown & Piombino, Brenda & - & - & $\mathbf{W}$ & $\mathbf{H}$ & 625 & $\mathbf{s}$ & 377CCKS \\
\hline 3219 & 4002430755343 & West Caln & Brass, Robert & 0308 & 1987 & $\mathbf{W}$ & $\mathbf{H}$ & 940 & $\mathbf{S}$ & 377CCKS \\
\hline 3301 & 3959140755538 & Sadsbury & White, Kirk & 1290 & - & $\mathbf{w}$ & $\mathbf{H}$ & 690 & $\mathbf{s}$ & 400FMFG \\
\hline 3315 & 4002380755356 & West Caln & Stasny, John & 1308 & 1988 & $\mathbf{w}$ & $\mathbf{H}$ & 910 & $\mathbf{S}$ & $377 \mathrm{CCKS}$ \\
\hline 3325 & 3959200755755 & W. Sadsbury & Castelli, Pat & - & - & $\mathbf{w}$ & $\mathbf{H}$ & 791 & $\mathbf{H}$ & 377CCKS \\
\hline 3326 & 4000050755415 & West Caln & Mouday, Joseph & 0319 & 1987 & $\mathbf{w}$ & $\mathbf{H}$ & 770 & $\mathbf{H}$ & 377CCKS \\
\hline 3327 & 4002120755411 & West Caln & Baldwin, A. & 1290 & 1977 & $\mathbf{w}$ & $\mathbf{P}$ & 908 & $\mathbf{S}$ & 377CCKS \\
\hline 3328 & $400105 \quad 0755348$ & West Caln & Cresmer, Bernadette & 0904 & 1980 & $\mathbf{w}$ & $\mathbf{H}$ & 728 & $\mathbf{S}$ & 377CCKS \\
\hline 3329 & 4002510755312 & West Caln & Sarmento, Peter & 1628 & 1985 & $\mathbf{W}$ & $\mathbf{H}$ & 925 & $\mathbf{H}$ & 377CCKS \\
\hline 3330 & $400010 \quad 0755650$ & W. Sadsbury & Mabry, Kenneth & - & 1965 & $\mathbf{w}$ & $\mathbf{H}$ & 857 & $\mathbf{H}$ & 377CCKS \\
\hline 3331 & 4005070752924 & Schuylkill & Osinski & - & 1957 & $\mathbf{w}$ & $\mathbf{H}$ & 615 & $\mathbf{H}$ & $377 \mathrm{CCKS}$ \\
\hline 3332 & 4001250755602 & West Caln & Bednar, Paul & 0904 & -- & $\mathbf{w}$ & $\mathbf{H}$ & 660 & $\mathbf{s}$ & 377ANTM \\
\hline 3333 & 4004570753002 & Tredyffrin & Trimble, John & 0188 & 1960 & $\mathbf{W}$ & $\mathbf{H}$ & 589 & $\mathbf{H}$ & 377CCKS \\
\hline 3334 & 4005100752925 & Schuylkill & Pyle, Ed & 0248 & 1983 & $\mathbf{w}$ & $\mathbf{H}$ & 585 & $\mathbf{s}$ & 377CCKS \\
\hline 3335 & 4003320753618 & Charlestown & Murphy, Jim & 1290 & 1982 & $\mathbf{W}$ & $\mathbf{H}$ & 610 & $\mathbf{s}$ & 377CCKS \\
\hline 3336 & 4004540753046 & Charlestown & Chambers, Laurence & 1628 & 1986 & $\mathbf{w}$ & $\mathbf{H}$ & 500 & $\mathbf{S}$ & 377CCKS \\
\hline 3337 & 4002320755257 & West Caln & Fling, Brian & 1308 & 1986 & $\mathbf{w}$ & $\mathbf{H}$ & 760 & $\mathbf{s}$ & 377CCKS \\
\hline 3338 & 4004210753400 & Charlestown & Benton, Mike & 0904 & - & $\mathbf{w}$ & $\mathbf{H}$ & 625 & $\mathbf{S}$ & 377CCKS \\
\hline 3339 & 4003480753515 & Charlestown & Klagholz, Michael & 1609 & 1986 & $\mathbf{w}$ & $\mathbf{H}$ & 620 & $\mathbf{S}$ & 377CCKS \\
\hline SP33 & 4004580752850 & Tredyffrin & Linton, Otto & -- & -- & $\mathbf{w}$ & $\mathbf{R}$ & 420 & $\mathbf{S}$ & 377HRPR \\
\hline LN-1684 & $400621 \quad 0755747$ & Caernarvon & Swisher, Evelyn & 1539 & 1985 & $\mathbf{w}$ & $\mathbf{H}$ & 915 & $\mathrm{~s}$ & 377CCKS \\
\hline 1685 & 3959390755830 & Salisbury & Hodges, Bob & 0308 & 1980 & $\mathbf{w}$ & $\mathrm{H}$ & 800 & $\mathbf{S}$ & 377CCKS \\
\hline 1686 & 4004320760053 & Salisbury & Kiser, Dale & 0319 & 1981 & $\mathbf{w}$ & $\mathbf{H}$ & 978 & $\mathbf{s}$ & 377CCKS \\
\hline 1687 & 4005340760109 & E. Earl & Shriver, Joseph & 0308 & 1978 & $\mathbf{w}$ & $\mathrm{H}$ & 825 & $\mathbf{S}$ & 377CCKS \\
\hline 1688 & 3957320760609 & Paradise & Wertz, Gerald & 0274 & 1986 & $\mathbf{w}$ & $\mathrm{H}$ & 818 & $\mathbf{H}$ & 377CCKS \\
\hline 1689 & 3956380760806 & Eden & Riehl, Jesse S. & 0110 & 1986 & $\mathbf{W}$ & $\mathrm{H}$ & 900 & $\mathbf{S}$ & 377CCKS \\
\hline 1690 & 4003130763052 & W. Hempfield & Divet, L. & -- & - & $\mathbf{w}$ & $\mathbf{H}$ & 540 & $\mathbf{H}$ & 377CCKS \\
\hline 1691 & 4003010762759 & W. Hempfield & Bennett, William & 0319 & - & $\mathbf{w}$ & $\mathrm{H}$ & 680 & $\mathbf{H}$ & $377 \mathrm{CCKS}$ \\
\hline 1692 & 3956070760456 & Bart & Prugh, John & 0110 & 1980 & w & H & 670 & $\mathbf{S}$ & 377CCKS \\
\hline 1693 & $395910 \quad 0760146$ & Salisbury & Byrd, Michael W. & MYER & 1970 & w & $\mathbf{H}$ & 580 & $\mathbf{s}$ & 377CCKS \\
\hline
\end{tabular}




\begin{tabular}{|c|c|c|c|c|c|c|c|c|c|c|c|c|c|}
\hline \multirow{3}{*}{$\begin{array}{l}\text { Depth } \\
\text { of } \\
\text { well } \\
\text { (feet) }\end{array}$} & & & \multirow{3}{*}{$\begin{array}{c}\text { Depth to } \\
\text { water-bearing } \\
\text { zone(s) } \\
\text { (feet) }\end{array}$} & \multirow{3}{*}{$\begin{array}{l}\text { Water } \\
\text { level } \\
\text { (feet) }\end{array}$} & \multirow{3}{*}{$\begin{array}{c}\text { Date } \\
\text { water } \\
\text { level } \\
\text { measured }\end{array}$} & \multirow{3}{*}{$\begin{array}{l}\text { Reported } \\
\text { yield } \\
\text { (gal/ } \\
\text { min) }\end{array}$} & \multicolumn{3}{|c|}{ Measured yield } & \multicolumn{3}{|c|}{ Field water quality } & \multirow{3}{*}{$\begin{array}{c}\text { USGS } \\
\text { well } \\
\text { number } \\
\text { or spring }\end{array}$} \\
\hline & \multicolumn{2}{|c|}{ Casing } & & & & & $\begin{array}{l}\text { Specific } \\
\text { capacity }\end{array}$ & $\begin{array}{c}\text { Dis- } \\
\text { charge }\end{array}$ & Pumping & & $\begin{array}{l}\text { Specific } \\
\text { conduc- }\end{array}$ & $\begin{array}{c}\text { pH } \\
\text { (stan- }\end{array}$ & \\
\hline & $\begin{array}{l}\text { Depth } \\
\text { (feet) }\end{array}$ & $\begin{array}{r}\text { Diameter } \\
\text { (inches) }\end{array}$ & & & & & $\begin{array}{c}{[(\mathrm{gal} /} \\
\min ) / \mathrm{ft}]\end{array}$ & $\begin{array}{l}\text { (gal/ } \\
\text { min) }\end{array}$ & $\begin{array}{l}\text { period } \\
\text { (hours) }\end{array}$ & $\begin{array}{c}\text { Date } \\
\text { measured }\end{array}$ & $\begin{array}{c}\text { tance } \\
(\mu \mathrm{S} / \mathrm{cm})\end{array}$ & $\begin{array}{l}\text { dard } \\
\text { units) }\end{array}$ & \\
\hline 330 & 72 & 6 & $90 / 285$ & 32.80 & $09-16-87$ & 7 & - & - & - & $08-22-88$ & 37 & 5.1 & $3160-\mathrm{CH}$ \\
\hline 277 & 99 & 6 & $125 / 245$ & 71.90 & $09-18-87$ & 2 & -- & - & - & $10-19-87$ & 23 & 5.0 & 3166 \\
\hline 188 & 38 & 6 & 171 & 79.60 & $09-29-87$ & -- & 0.02 & 3 & - & $09-29-87$ & 114 & 4.7 & 3168 \\
\hline 220 & 60 & 6 & 110 & 70.00 & $08-30-88$ & 10 & - & - & - & $08-30-88$ & 37 & 4.9 & 3189 \\
\hline 221 & 47 & 6 & 105 & 77.80 & $10-21-87$ & 2 & -- & - & -- & $10-21-87$ & 116 & 5.3 & 3213 \\
\hline 70 & 42 & 6 & $50 / 55 / 60$ & 36.70 & $10-22-87$ & 30 & - & - & 1 & $10-22-87$ & 226 & 4.6 & 3214 \\
\hline 109 & -- & -- & - & - & - & - & - & -- & - & $10-23-87$ & 465 & 5.3 & 3215 \\
\hline 335 & 60 & 6 & $155 / 290 / 300 / 315$ & 66.00 & $06-16-88$ & -- & .03 & 4 & .5 & $06-16-88$ & 44 & 5.4 & 3219 \\
\hline 175 & -- & -- & -- & 40.20 & $06-16-88$ & -- & - & - & - & $06-16-88$ & 34 & 5.2 & 3301 \\
\hline 225 & 26 & 6 & $70 / 100$ & 44.90 & $09-01-88$ & 3 & - & - & - & $09-01-88$ & 58 & 4.8 & 3315 \\
\hline -- & -- & -- & -- & 46.20 & $08-16-88$ & -- & -- & -- & - & $08-16-88$ & 130 & 4.6 & 3325 \\
\hline 200 & 74 & 6 & -- & 47.50 & $08-16-88$ & 4 & - & -- & - & $08-16-88$ & 92 & 6.3 & 3326 \\
\hline 195 & 21 & 6 & $95 / 120$ & 80.50 & $08-26-88$ & 3 & -. & - & 1 & $08-26-88$ & 77 & 4.4 & 3327 \\
\hline -- & - & -- & - & -- & - & - & - & -- & -- & $08-26-88$ & 53 & 5.3 & 3328 \\
\hline 175 & 34 & 6 & $70 / 80$ & 31.00 & $08-22-88$ & 8 & - & -- & - & $08-22-88$ & 36 & 4.9 & 3329 \\
\hline 87 & 35 & 6 & - & 15.00 & $00-00-87$ & 40 & - & -- & -- & $08-23-88$ & 57 & 4.7 & 3330 \\
\hline 120 & - & -- & - & -- & -- & -. & -- & - & - & $08-23-88$ & 245 & 4.4 & 3331 \\
\hline- & - & - & - & 53.40 & $08-30-88$ & -- & -- & - & - & $08-30-88$ & 150 & 5.6 & 3332 \\
\hline- & - & - & - & - & -- & - & - & - & - & $09-06-88$ & 75 & 4.8 & 3333 \\
\hline 243 & 121 & 6 & $145 / 190 / 218$ & 68.30 & $09-06-88$ & 20 & -- & - & - & $09-06-88$ & 49 & 5.1 & 3334 \\
\hline 150 & 20 & 6 & $66 / 130$ & 33.80 & $09-06-88$ & 20 & -- & -- & - & $09-06-88$ & 370 & 4.6 & 3335 \\
\hline 280 & 84 & 6 & $90 / 200$ & 46.60 & $09-06-88$ & 8 & - & - & -- & $09-06-88$ & 105 & 5.9 & 3336 \\
\hline 120 & 78 & 6 & 85 & 28.60 & $09-08-88$ & 8 & - & - & - & $09-08-88$ & 29 & 5.7 & 3337 \\
\hline 143 & 42 & 6 & 135 & 45.50 & $09-08-88$ & - & .07 & 6 & 4 & $09-08-88$ & 160 & 4.5 & 3338 \\
\hline 220 & 98 & 6 & $65 / 127 / 192$ & 69.90 & $09-09-88$ & - & .07 & 9 & 3 & $09-09-88$ & 110 & 5.2 & 3339 \\
\hline- & - & -- & - & -- & -- & - & - & - & - & $07-27-87$ & 102 & 5.4 & SP33 \\
\hline 300 & 60 & 6 & 260 & 85.00 & $10-28-85$ & -- & .01 & 2 & 4.7 & $11-21-86$ & 16 & 5.6 & 1984-LN \\
\hline 140 & 40 & 6 & $45 / 80 / 125 / 130$ & 40.00 & $07-00-80$ & 14 & -- & -- & - & $12-03-86$ & 633 & 6.2 & 1685 \\
\hline 275 & 102 & 6 & $106 / 257$ & 12.20 & $12-03-86$ & 16 & -. & -- & -- & $12-03-86$ & 18 & 5.2 & 1686 \\
\hline 270 & 60 & 6 & -- & 79.00 & $12-03-86$ & - & .05 & 3 & - & $12-03-86$ & 46 & 4.8 & 1687 \\
\hline 142 & 20 & 6 & - & 52.20 & $12-04-86$ & - & .10 & 10 & 1 & $12-04-86$ & 341 & 4.4 & 1688 \\
\hline 400 & 80 & 6 & 193 & 54.80 & $12-08-86$ & - & .00 & $<1$ & 1.0 & $12-08-86$ & 171 & 5.7 & 1689 \\
\hline 144 & - & - & -- & - & - & - & - & - & - & $12-08-86$ & 166 & 5.1 & 1690 \\
\hline 275 & - & - & - & 86.80 & $12-12-86$ & - & - & - & - & $12-12-86$ & 151 & 6.4 & 1691 \\
\hline 105 & 67 & 6 & $75 / 95$ & 50.40 & $12-30-86$ & - & .50 & 15 & .7 & $12-30-86$ & 118 & 5.8 & 1692 \\
\hline 120 & 90 & -- & - & 19.80 & $12-30-86$ & 7 & - & - & - & $12-30-86$ & 60 & 5.6 & 1693 \\
\hline
\end{tabular}


Table 20. Records of wells and springs--Continued

\begin{tabular}{|c|c|c|c|c|c|c|c|c|c|c|}
\hline \multirow{2}{*}{$\begin{array}{l}\text { USGS } \\
\text { well } \\
\text { number } \\
\text { or spring }\end{array}$} & \multirow[b]{2}{*}{$\begin{array}{l}\text { Location } \\
\text { Latitude Longitude } \\
\text { (degrees) }\end{array}$} & \multirow[b]{2}{*}{$\begin{array}{l}\text { Township } \\
\text { or } \\
\text { borough }\end{array}$} & \multirow[b]{2}{*}{ Owner } & \multirow[b]{2}{*}{$\begin{array}{l}\text { Driller } \\
\text { license } \\
\text { number }\end{array}$} & \multirow[b]{2}{*}{$\begin{array}{c}\text { Year } \\
\text { drilled }\end{array}$} & \multicolumn{2}{|c|}{ Primary } & \multirow{2}{*}{$\begin{array}{l}\text { Altitude } \\
\text { of land } \\
\text { surface } \\
\text { (feet) }\end{array}$} & \multirow[b]{2}{*}{$\begin{array}{l}\text { Topo- } \\
\text { graphic } \\
\text { setting }\end{array}$} & \multirow[b]{2}{*}{$\begin{array}{l}\text { Hydro- } \\
\text { geologic } \\
\text { unit }\end{array}$} \\
\hline & & & & & & $\begin{array}{l}\text { Use } \\
\text { of } \\
\text { site }\end{array}$ & $\begin{array}{c}\text { Use } \\
\text { of } \\
\text { water }\end{array}$ & & & \\
\hline LN-1694 & 4004430760101 & East Ear] & Giza, David & 0319 & 1979 & $\mathbf{W}$ & $\mathrm{H}$ & 1020 & $\mathbf{H}$ & $377 \mathrm{CCKS}$ \\
\hline 1695 & $395920 \quad 0755845$ & Salisbury & Elmer, Harold & 0308 & 1982 & $\mathbf{W}$ & $\mathbf{H}$ & 845 & $\mathbf{H}$ & $377 \mathrm{CCKS}$ \\
\hline 1696 & 4005490755841 & Salisbury & Martin, Nevin & 1258 & 1979 & $\mathbf{W}$ & $\mathbf{H}$ & 950 & $\mathbf{H}$ & 377CCKS \\
\hline 1697 & 3959360755823 & Salisbury & Hershey, Everett & - & -- & W & $\mathbf{H}$ & 865 & $\mathbf{H}$ & $377 \mathrm{CCKS}$ \\
\hline 1698 & 3959370755817 & Salisbury & Martin, Eugene & 0308 & -- & $\mathbf{w}$ & $\mathrm{H}$ & 862 & $\mathbf{H}$ & $377 \mathrm{CCKS}$ \\
\hline 1699 & 4006010755841 & Caernarvon & Clevely, Robert & 1258 & -- & w & $\mathbf{H}$ & 855 & $\mathbf{s}$ & $377 \mathrm{CCKS}$ \\
\hline 1700 & 4005550755840 & Caernavon & Oestereich, Mary Ann & 1628 & 1978 & $\mathbf{w}$ & $\mathrm{H}$ & 930 & $\mathbf{S}$ & 377CCKS \\
\hline 1701 & 4004330760054 & Salisbury & Barrows, William & 0308 & 1984 & $\mathbf{w}$ & $\mathbf{H}$ & 990 & $\mathrm{~s}$ & 377CCKS \\
\hline 1713 & 4005470755820 & Salisbury & Platt, George & 1539 & 1988 & $\mathbf{w}$ & H & 880 & $\mathbf{H}$ & 377CCKS \\
\hline 1714 & 3959070755923 & Sadsbury & Jordan, Ronald & 1628 & 1987 & $\mathbf{w}$ & $\mathbf{H}$ & 720 & $\mathbf{S}$ & 377CCKS \\
\hline 1715 & 4005440755845 & Salisbury & Blume, Ryan & 0319 & 1988 & $\mathbf{w}$ & $\mathrm{H}$ & 880 & $\mathrm{~s}$ & 377CCKS \\
\hline 1716 & 3959270755931 & Salisbury & Stoltzfus, Nathan & 0319 & 1988 & $\mathbf{W}$ & $\mathbf{H}$ & 715 & $\mathbf{S}$ & 377CCKS \\
\hline 1717 & 3957180760644 & Paradise & Forrester, Cecil & 0319 & 1985 & $\mathbf{W}$ & $\mathrm{H}$ & 790 & $\mathbf{H}$ & 377CCKS \\
\hline 1718 & 3957530760712 & Paradise & Reese, Robert & 0308 & 1986 & $\mathbf{W}$ & $\mathrm{H}$ & 600 & $\mathbf{S}$ & 377ANTM \\
\hline 1719 & 3956420760805 & Eden & Duffy, Robert & -- & - & w & $\mathrm{H}$ & 917 & $\mathbf{H}$ & 377CCKS \\
\hline 1720 & 3957310760659 & Paradise & Hess, Gary & 0319 & 1977 & $\mathbf{W}$ & $\mathrm{H}$ & 780 & $\mathbf{S}$ & 377HRPR \\
\hline 1721 & 3958080760401 & Paradise & Beiler, Clair & 0110 & 1986 & $\mathbf{w}$ & $\mathrm{H}$ & 818 & $\mathbf{H}$ & 377CCKS \\
\hline 1722 & 3958340760426 & Paradise & Loney, John & 0308 & 1986 & $\mathbf{w}$ & $\mathbf{H}$ & 680 & $\mathbf{S}$ & $377 \mathrm{CCKS}$ \\
\hline 1723 & 3958240760413 & Paradise & Wohlert, Paul & -- & 1972 & $\mathbf{W}$ & $\mathrm{H}$ & 750 & $\mathbf{S}$ & 377CCKS \\
\hline 1724 & 3956170760810 & Eden & Dunn, Cindy & 0319 & 1986 & $\mathbf{W}$ & $\mathbf{H}$ & 820 & $\mathbf{S}$ & 377CCKS \\
\hline 1725 & $395925 \quad 0755835$ & Salisbury & Bidwell, Randy & 0319 & 1986 & $\mathbf{w}$ & $\mathbf{H}$ & 875 & $\mathrm{H}$ & 377CCKS \\
\hline 1726 & 3959220755836 & Salisbury & Johnson, Henry & 0319 & 1986 & $\mathbf{w}$ & $\mathbf{H}$ & 885 & $\mathrm{H}$ & 377CCKS \\
\hline 1727 & $395637 \quad 0760843$ & Strasburg & Knerr, Fritz & 0319 & 1985 & $\mathbf{W}$ & $\mathbf{H}$ & 845 & $\mathbf{H}$ & 377CCKS \\
\hline 1728 & 4003340762801 & W. Hempfield & Scantling, Walter & 0319 & 1985 & $\mathbf{w}$ & $\mathbf{H}$ & 620 & $\mathbf{H}$ & $377 \mathrm{CCKS}$ \\
\hline 1730 & 3958090760732 & Paradise & Boyd, Dennis & 0110 & 1975 & $\mathbf{W}$ & $\mathrm{H}$ & 490 & $\mathbf{S}$ & 367CNSG \\
\hline 1731 & $395618 \quad 0760147$ & Sadsbury & Lapp, Benjamin & 0319 & 1986 & $\mathbf{w}$ & $\mathrm{H}$ & 615 & $\mathbf{H}$ & $377 \mathrm{CCKS}$ \\
\hline 1732 & $400416 \quad 0760018$ & Salisbury & Shaub, Mary Lou & 0308 & - & $\mathbf{w}$ & $\mathrm{H}$ & 910 & $\mathbf{s}$ & $377 \mathrm{CCKS}$ \\
\hline 1733 & 4005470760121 & East Earl & Shirk, Larry & 1539 & 1986 & $\mathbf{W}$ & $\mathrm{H}$ & 753 & $\mathbf{S}$ & 377ANTM \\
\hline 1734 & 3959170755923 & Salisbury & Sosko, Ken & 0319 & 1970 & $\mathbf{w}$ & H & 795 & $\mathbf{H}$ & $377 \mathrm{CCKS}$ \\
\hline 1735 & 4004350760127 & East Earl & Sensenig, Gary & 0319 & 1979 & $\mathbf{w}$ & $\mathrm{H}$ & 960 & $\mathbf{S}$ & 377CCKS \\
\hline 1736 & $400658 \quad 0755546$ & Caernarvon & Krieger, Thomas & 1290 & 1988 & $\mathbf{w}$ & $\mathbf{H}$ & 922 & $\mathbf{S}$ & 377CCKS \\
\hline 1737 & 4006540755546 & Caernarvon & Smith, Brad & 1290 & 1988 & $\mathbf{w}$ & $\mathbf{H}$ & 900 & $\mathbf{S}$ & 377CCKS \\
\hline 1738 & $400617 \quad 0755745$ & Caernarvon & Zimmerman, Tammy & 0308 & 1986 & $\mathbf{w}$ & $\mathbf{H}$ & 960 & $\mathbf{s}$ & 377CCKS \\
\hline 1739 & $400554 \quad 0755815$ & Salisbury & Senn, Bruce & 0308 & 1988 & w & $\mathbf{H}$ & 962 & $\mathbf{H}$ & $377 \mathrm{CCKS}$ \\
\hline 1740 & $400605 \quad 0755755$ & Caernarvon & Hicks, Roger & 0319 & 1986 & $\mathbf{w}$ & $\mathrm{H}$ & 925 & $\underline{H}$ & 377CCKS \\
\hline 1741 & $400606 \quad 0755748$ & Salisbury & Heagy, Jeff & 0319 & 1987 & $\mathbf{w}$ & $\mathbf{H}$ & 925 & $\mathbf{S}$ & 377CCKS \\
\hline
\end{tabular}


Table 20. Records of wells and springs--Continued

\begin{tabular}{|c|c|c|c|c|c|c|c|c|c|c|c|c|c|}
\hline \multirow{3}{*}{$\begin{array}{l}\text { Depth } \\
\text { of } \\
\text { well } \\
\text { (feet) }\end{array}$} & & & \multirow{3}{*}{$\begin{array}{l}\text { Depth to } \\
\text { water-bearing } \\
\text { zone(s) } \\
\text { (feet) }\end{array}$} & \multirow{3}{*}{$\begin{array}{l}\text { Water } \\
\text { level } \\
\text { (feet) }\end{array}$} & \multirow{3}{*}{$\begin{array}{c}\text { Date } \\
\text { water } \\
\text { level } \\
\text { measured }\end{array}$} & \multirow{3}{*}{$\begin{array}{l}\text { Reported } \\
\text { yield } \\
\text { (gal/ } \\
\text { min) }\end{array}$} & \multicolumn{3}{|c|}{ Measured yield } & \multicolumn{3}{|c|}{ Field water guality } & \multirow{3}{*}{$\begin{array}{c}\text { USGS } \\
\text { well } \\
\text { number } \\
\text { or spring }\end{array}$} \\
\hline & \multicolumn{2}{|c|}{ Casing } & & & & & $\begin{array}{l}\text { Specific } \\
\text { capacity }\end{array}$ & $\begin{array}{c}\text { Dis- } \\
\text { charge }\end{array}$ & Pumping & & $\begin{array}{l}\text { Specific } \\
\text { conduc- }\end{array}$ & $\begin{array}{c}\mathrm{pH} \\
\text { (stan- }\end{array}$ & \\
\hline & $\begin{array}{l}\text { Depth } \\
\text { (feet) }\end{array}$ & $\begin{array}{c}\text { Diameter } \\
\text { (inches) }\end{array}$ & & & & & $\begin{array}{c}{[(\mathrm{gal} /} \\
\min ) / \mathrm{ft}]\end{array}$ & $\begin{array}{l}\text { (gal/ } \\
\mathrm{min})\end{array}$ & $\begin{array}{c}\text { period } \\
\text { (hours) }\end{array}$ & $\begin{array}{c}\text { Date } \\
\text { measured }\end{array}$ & $\begin{array}{c}\operatorname{tance} \\
(\mu \mathrm{S} / \mathrm{cm})\end{array}$ & $\begin{array}{c}\text { dard } \\
\text { units) }\end{array}$ & \\
\hline 200 & 111 & 6 & $120 / 147$ & - & - & 7 & -. & - & - & $12-30-86$ & 42 & 5.1 & $1694-\mathrm{LN}$ \\
\hline 160 & 82 & 6 & $110 / 130 / 140$ & 68.90 & $12-30-86$ & -- & 0.25 & 20 & 0.5 & $12-30-86$ & 63 & 4.9 & 1695 \\
\hline- & -. & -- & - & 74.80 & $07-08-87$ & -- & - & - & .. & $07-08-87$ & 67 & 4.7 & 1696 \\
\hline 70 & -- & - & - & -- & -- & - & - & - & -- & $07-27-87$ & 187 & 4.3 & 1697 \\
\hline 217 & - & -- & - & -- & -- & -- & -- & - & - & $07-13-87$ & 214 & 4.4 & 1698 \\
\hline 125 & - & -- & - & 94.20 & $07-14-87$ & 30 & -- & - & - & $07-14-87$ & 12 & 5.2 & 1699 \\
\hline 295 & 145 & 6 & $175 / 280$ & 130.00 & $07-15-87$ & 4 & - & - & - & $07-15-87$ & 12 & 5.4 & 1700 \\
\hline 220 & 100 & 6 & $170 / 196 / 198$ & 46.40 & $07-15-87$ & - & .10 & 15 & .5 & $07-15-87$ & 54 & 5.8 & 1701 \\
\hline 123 & 88 & 6 & 90 & 41.80 & $06-27-88$ & 40 & - & - & -- & $09-01-88$ & 49 & 5.1 & 1713 \\
\hline 270 & 30 & 6 & - & 15.80 & $08-25-88$ & 2 & -- & - & - & $08-25-88$ & 103 & 5.0 & 1714 \\
\hline 125 & 62 & 63 & $38 / 66 / 80 / 110$ & 15.80 & $08-27-88$ & 30 & -- & - & $\cdots$ & $08-27-88$ & 21 & 5.2 & 1715 \\
\hline 175 & 85 & 6 & $95 / 155 / 175$ & 55.00 & $07-18-88$ & 10 & - & - & - & $08-25-88$ & 30 & 5.1 & 1716 \\
\hline 150 & 72 & 6 & $103 / 137$ & 31.10 & $08-03-88$ & 7 & - & - & -- & $08-03-88$ & 320 & 4.7 & 1717 \\
\hline 120 & 40 & 6 & $90 / 100$ & 39.80 & 08-03-88 & - & .07 & 4 & .5 & $08-03-88$ & 250 & 5.3 & 1718 \\
\hline -. & -- & - & - & - & -- & - & - & -- & -- & 08-03-88 & 71 & 4.8 & 1719 \\
\hline 300 & 21 & 6 & - & 42.90 & $08-04-88$ & 1 & - & -. & - & $08-04-88$ & 120 & 5.1 & 1720 \\
\hline 135 & 86 & 6 & $115 / 130 / 134$ & 38.10 & $08-04-88$ & - & 1.5 & 15 & 1.0 & $08-04-88$ & 215 & 4.9 & 1721 \\
\hline 273 & 40 & 6 & $59 / 135$ & 55.50 & $08-04-88$ & -- & .04 & 4 & .5 & $08-04-88$ & 119 & 5.8 & 1722 \\
\hline 215 & - & -- & -. & -- & - & $\cdots$ & -- & - & - & $08-04-88$ & 105 & 5.0 & 1723 \\
\hline 250 & 41 & 6 & $\cdots$ & 71.00 & $08-05-88$ & 3 & -. & - & -- & 08-05-88 & 115 & 5.3 & 1724 \\
\hline 175 & 51 & 6 & $108 / 167$ & -- & - & 15 & - & - & - & $08-05-88$ & 165 & 4.5 & 1725 \\
\hline 175 & 60 & 6 & $76 / 160$ & 69.40 & $08-05-88$ & 6 & - & - & -- & $08-05-88$ & 54 & 4.7 & 1726 \\
\hline 250 & 80 & 6 & $110 / 142 / 235$ & 83.80 & $08-08-88$ & 5 & - & - & - & $08-08-88$ & 49 & 5.4 & 1727 \\
\hline 250 & 102 & 6 & $125 / 230$ & - & - & 6 & - & - & 1 & $08-08-88$ & 80 & 5.7 & 1728 \\
\hline 112 & -- & - & - & 2.75 & $08-13-88$ & -- & - & - & -- & $08-13-88$ & 420 & 7.7 & 1730 \\
\hline 228 & 75 & 6 & $98 / 160$ & 30.00 & 08-13-88 & 2 & - & - & - & $08-13-88$ & 190 & 5.7 & 1731 \\
\hline 213 & 41 & 6 & -- & 49.20 & $08-15-88$ & -- & - & - & -- & $08-15-88$ & 110 & 4.4 & 1732 \\
\hline 135 & 80 & 6 & $105 / 120$ & 74.30 & $08-15-88$ & 18 & - & - & 5 & $08-15-88$ & 46 & 5.3 & 1733 \\
\hline 90 & 40 & 6 & - & - & -- & 10 & - & -. & - & $08-25-88$ & 175 & 4.7 & 1734 \\
\hline 100 & 41 & 6 & -- & 39.10 & $08-15-88$ & 20 & - & -- & - & $08-17-88$ & 68 & 4.8 & 1735 \\
\hline 230 & 100 & 6 & $110 / 180$ & 36.40 & $08-17-88$ & 20 & -- & - & -- & $08-17-88$ & 45 & 5.0 & 1736 \\
\hline 280 & 125 & 6 & $130 / 260$ & 34.70 & $08-17-88$ & 3 & -- & -- & - & $08-17-88$ & 43 & 5.5 & 1737 \\
\hline 407 & 60 & 6 & $300 / 375$ & 125.00 & $09-02-88$ & 2 & - & -- & .5 & $09-02-88$ & - & 4.7 & 1738 \\
\hline 318 & 40 & 6 & $96 / 185 / 274$ & 78.60 & $09-01-88$ & -. & .02 & 4 & .5 & $09-01-88$ & 77 & 4.4 & 1739 \\
\hline 325 & 100 & 6 & $130 / 210 / 298$ & 85.00 & $09-02-88$ & 2 & -- & - & - & $09-02-88$ & 17 & 5.3 & 1740 \\
\hline 150 & 77 & 6 & $92 / 134$ & 70.90 & $09-02-88$ & 20 & - & -- & - & $09-02-88$ & 17 & 5.3 & 1741 \\
\hline
\end{tabular}


Table 20. Records of wells and springs--Continued

\begin{tabular}{|c|c|c|c|c|c|c|c|c|c|c|}
\hline \multirow{2}{*}{$\begin{array}{l}\text { USGS } \\
\text { well } \\
\text { number } \\
\text { or spring }\end{array}$} & \multirow[b]{2}{*}{$\begin{array}{l}\text { Location } \\
\text { Latitude Longitude } \\
\text { (degrees) }\end{array}$} & \multirow[b]{2}{*}{$\begin{array}{l}\text { Township } \\
\text { or } \\
\text { borough }\end{array}$} & \multirow[b]{2}{*}{ Owner } & \multirow[b]{2}{*}{$\begin{array}{l}\text { license } \\
\text { number }\end{array}$} & \multirow[b]{2}{*}{$\begin{array}{c}\text { Driller } \\
\text { Year } \\
\text { drilled }\end{array}$} & \multicolumn{2}{|c|}{ Primary } & \multirow{2}{*}{$\begin{array}{l}\text { Altitude } \\
\text { of land } \\
\text { surface } \\
\text { (feet) }\end{array}$} & \multirow[b]{2}{*}{$\begin{array}{l}\text { Topo- } \\
\text { graphic } \\
\text { setting }\end{array}$} & \multirow[b]{2}{*}{$\begin{array}{l}\text { Hydro- } \\
\text { geologic } \\
\text { unit }\end{array}$} \\
\hline & & & & & & $\begin{array}{l}\text { Use } \\
\text { of } \\
\text { site }\end{array}$ & $\begin{array}{l}\text { Use } \\
\text { of } \\
\text { water }\end{array}$ & & & \\
\hline LN-1742 & 4005380755818 & Salisbury & Boyce, Dale & 1539 & 1988 & w & $\mathbf{H}$ & 818 & $\mathbf{s}$ & OOOGBBR \\
\hline MG- 399 & $400755 \quad 0751033$ & U Dublin & Manufacturers G \& C Club & b 0249 & 1954 & $\mathbf{w}$ & $\mathrm{H}$ & 350 & $\mathbf{S}$ & $377 \mathrm{CCKS}$ \\
\hline 1000 & 4009080750537 & U Moreland & DeFlavis, David & -- & - & $\mathbf{W}$ & $\mathbf{H}$ & 340 & $\mathbf{H}$ & $377 \mathrm{CCKS}$ \\
\hline 1001 & 4007450751120 & U Dublin & Neuman, Richard & -- & -- & $\mathbf{w}$ & $\mathbf{H}$ & 240 & $\mathbf{S}$ & 377CCKS \\
\hline 1002 & 4007010751353 & Whitemarsh & Ft. Washington State Park & 0514 & 1958 & $\mathbf{U}$ & $\mathrm{U}$ & 215 & $\mathbf{S}$ & 377LDGR \\
\hline 1003 & 4007030751508 & Whitemarsh & Ahner, William & -- & -- & $\mathbf{w}$ & $\mathbf{H}$ & 235 & $\mathbf{H}$ & 377LDGR \\
\hline 1004 & $400647 \quad 0751717$ & Plymouth & Souder, Bruce (tenant) &.- & -- & $\mathbf{w}$ & $\mathbf{H}$ & 230 & $\mathrm{H}$ & $377 \mathrm{CCKS}$ \\
\hline YO- 88 & 4000330763923 & Springettsbury & York County Planning & 0356 & 1971 & w & $\mathbf{P}$ & 800 & $\mathbf{w}$ & 377CCKS \\
\hline 351 & 3952360765439 & Jackson & Hartman, Charles & 0383 & 1965 & $\mathbf{w}$ & $\mathbf{H}$ & 785 & $\mathbf{H}$ & $377 \mathrm{CCKS}$ \\
\hline 371 & 3950580765018 & N. Codorus & Smith, George H. & 0383 & 1967 & $\mathbf{w}$ & $\mathbf{H}$ & 823 & $\mathbf{H}$ & 377CCKS \\
\hline 650 & 3957170763454 & Lower Windsor & Ball, Elizabeth & -- & -- & w & $\mathbf{H}$ & 695 & $\mathbf{H}$ & 377CCKS \\
\hline 792 & 4001520763908 & Hellam & York Rifle Range Assoc. & -- & 1964 & w & $\mathbf{H}$ & 685 & $\mathbf{H}$ & 377CCKS \\
\hline 1148 & 4000230763919 & Springettsbury & Loucks, Ronald & 0198 & 1980 & w & $\mathrm{H}$ & 810 & $\mathbf{S}$ & $377 \mathrm{CCKS}$ \\
\hline 1149 & $400155 \quad 0763432$ & Hellam & Lauchman & 0741 & 1979 & $\mathbf{W}$ & $\mathbf{H}$ & 565 & $\mathbf{H}$ & $377 \mathrm{CCKS}$ \\
\hline 1150 & 4000070763200 & Lower Windsor & Keller, Donald & - & -- & $\mathbf{W}$ & $\mathbf{H}$ & 650 & $\mathbf{S}$ & $377 \mathrm{CCKS}$ \\
\hline 1151 & 3952360764655 & N. Codorus & Grammer, Alan & 1551 & 1980 & w & $\mathbf{H}$ & 700 & $\mathbf{S}$ & 377CCKS \\
\hline 1152 & 3951030765651 & Heidelberg & Withers, Donald & 0032 & 1979 & w & $\mathbf{H}$ & 1190 & $\mathbf{H}$ & $377 \mathrm{CCKS}$ \\
\hline 1153 & 3952450765409 & Jackson & Heiser, William & 0198 & 1985 & $\mathbf{w}$ & $\mathbf{H}$ & 785 & $\mathbf{H}$ & $377 \mathrm{CCKS}$ \\
\hline 1154 & 3958330763710 & Springettsbury & Koller, Timothy & 0741 & 1985 & w & $\mathbf{H}$ & 600 & $\mathbf{S}$ & $377 \mathrm{CCKS}$ \\
\hline 1155 & 3950490765830 & Heidelberg & Andes, Frank & 0741 & 1984 & w & $\mathbf{H}$ & 765 & $\mathbf{s}$ & $377 \mathrm{CCKS}$ \\
\hline 1156 & 3952510765428 & Jackson & Lain, Kevin & 0211 & 1981 & w & $\mathbf{H}$ & 710 & $\mathbf{s}$ & 377CCKS \\
\hline 1157 & 4000250764015 & Springettsbury & Mummert, Marlyn & -. & - & w & $\mathbf{H}$ & 840 & $\mathbf{H}$ & $377 \mathrm{CCKS}$ \\
\hline 1158 & 3952110765021 & N. Codorus & Paonessa, Samuel & - & - & $\mathbf{w}$ & $\mathrm{H}$ & 640 & $\mathrm{H}$ & $377 \mathrm{CCKS}$ \\
\hline 1159 & 3954190764643 & N. Codorus & Hartman, Wayne & -- & - & w & $\mathbf{H}$ & 610 & $\mathbf{H}$ & 377CCKS \\
\hline 1160 & $395516 \quad 0764452$ & Spring Garden & Ryan, E.W. & 1515 & 1980 & $\mathbf{W}$ & $\mathbf{H}$ & 430 & $\mathbf{S}$ & 377HRPR \\
\hline 1161 & 3959380763331 & Hellam & Keller, Scott & 0741 & 1984 & $\mathbf{W}$ & $\mathbf{H}$ & 710 & $\mathbf{s}$ & $377 \mathrm{CCKS}$ \\
\hline 1162 & $400103 \quad 0763919$ & Hellam & Beaverson, Richard & - & -- & $\mathbf{w}$ & $\mathbf{H}$ & 570 & $\mathbf{S}$ & 377HRPR \\
\hline 1163 & 4002430763242 & Hellam & Hovis, Raymond & 0356 & 1978 & $\mathbf{w}$ & $\mathbf{H}$ & 700 & $\mathrm{H}$ & $377 \mathrm{CCKS}$ \\
\hline 1164 & 4000220763914 & Springettsbury & Emswiler, Charles & 0356 & 1986 & $\mathbf{w}$ & $\mathbf{H}$ & 780 & $\mathbf{S}$ & $377 \mathrm{CCKS}$ \\
\hline 1165 & $400020 \quad 0763912$ & Springettsbury & Boll, $\mathrm{H}$. & 0356 & 1947 & $\mathbf{w}$ & H & 730 & $\mathbf{S}$ & 377CCKS \\
\hline 1166 & 4000390764124 & Springettsbury & Beaverson, Richard & 0356 & 1954 & $\mathbf{W}$ & $\mathbf{H}$ & 470 & $\mathbf{S}$ & $377 \mathrm{CCKS}$ \\
\hline 1167 & 4000040763910 & Springettsbury & Fetrow, Russell & 0356 & 1950 & $\mathbf{W}$ & $\mathbf{H}$ & 585 & $\mathbf{S}$ & 377HRPR \\
\hline 1168 & 3959570763904 & Springettsbury & Bates, Douglas & - & -- & $\mathbf{w}$ & $\mathbf{H}$ & 475 & $\mathbf{s}$ & $377 \mathrm{VNTG}$ \\
\hline 1172 & 4000230763919 & Springettsbury & Loucks, Ronald & 0356 & 1988 & $\mathbf{w}$ & $\mathbf{H}$ & 816 & $\mathbf{S}$ & 377CCKS \\
\hline 1175 & 4002450763225 & Hellam & Evans, Warren & 0356 & 1978 & w & $\mathrm{H}$ & 640 & $\mathbf{S}$ & 377CCKS \\
\hline 1176 & $400026 \quad 0764134$ & Springettsbury & Oberdick, Michael & 0741 & 1987 & $\mathbf{w}$ & $\mathrm{H}$ & 530 & $\mathbf{S}$ & 377CCKS \\
\hline
\end{tabular}




\begin{tabular}{|c|c|c|c|c|c|c|c|c|c|c|c|c|c|}
\hline \multirow[b]{2}{*}{$\begin{array}{l}\text { Depth } \\
\text { of } \\
\text { well } \\
\text { (feet) }\end{array}$} & & & \multirow[b]{2}{*}{$\begin{array}{l}\text { Depth to } \\
\text { water-bearing } \\
\text { zone(s) } \\
\text { (feet) }\end{array}$} & \multirow[b]{2}{*}{$\begin{array}{l}\text { Water } \\
\text { level } \\
\text { (feet) }\end{array}$} & \multirow[b]{2}{*}{$\begin{array}{c}\text { Date } \\
\text { water } \\
\text { level } \\
\text { measured }\end{array}$} & \multirow[b]{2}{*}{$\begin{array}{l}\text { Reported } \\
\text { yield } \\
\text { (galy } \\
\text { min) }\end{array}$} & \multicolumn{3}{|c|}{ Measured vield } & \multicolumn{3}{|c|}{ Field water auality } & \multirow[b]{2}{*}{$\begin{array}{c}\text { USGS } \\
\text { well } \\
\text { number } \\
\text { or spring }\end{array}$} \\
\hline & $\begin{array}{l}\text { Ca } \\
\text { Depth } \\
\text { (feet) }\end{array}$ & $\begin{array}{l}\text { Diameter } \\
\text { (inches) }\end{array}$ & & & & & $\begin{array}{c}\text { Specific } \\
\text { capacity } \\
{[(\mathrm{gaV}} \\
\mathrm{min}) / \mathrm{tt}]\end{array}$ & $\begin{array}{c}\text { Dis- } \\
\text { charge } \\
\text { (gaV } \\
\text { min) }\end{array}$ & $\begin{array}{c}\text { Pumping } \\
\text { period } \\
\text { (hours) }\end{array}$ & $\begin{array}{c}\text { Date } \\
\text { measured }\end{array}$ & $\begin{array}{c}\text { Specific } \\
\text { conduc- } \\
\text { tance } \\
(\mu \mathrm{S} / \mathrm{cm})\end{array}$ & $\begin{array}{c}\text { pH } \\
\text { (stan- } \\
\text { dard } \\
\text { units) }\end{array}$ & \\
\hline 120 & 81 & 6 & - & -1.00 & $09-02-88$ & 40 & -. & - & - & $09-02-88$ & 55 & 6.2 & $1742-\mathrm{LN}$ \\
\hline 400 & - & - & - & 72.00 & $04-08-54$ & 73 & -- & - & -- & $07-01-87$ & 329 & 6.3 & 399-MG \\
\hline- & -- & - & - & - & -- & - & -- & - & .. & $12-19-86$ & 186 & 6.3 & 1000 \\
\hline- & - & - & - & 13.50 & $12-29-86$ & - & - & - & - & $12-29-86$ & 204 & 6.3 & 1001 \\
\hline 170 & 140 & 4 & -- & 80.00 & $10-06-58$ & - & 1 & 25 & 92 & $01-08-87$ & 351 & 7.5 & 1002 \\
\hline 180 & - & - & - & - & - & -- & - & -- & - & $01-09-87$ & 626 & 7.3 & 1003 \\
\hline- & - & - & - & $\cdots$ & - & - & -- & -- & - & $01-13-87$ & 335 & 5.9 & 1004 \\
\hline 110 & 30 & 6 & 90 & - & - & 90 & - & - & - & $07-21-89$ & 39 & 5.9 & 88-YO \\
\hline 110 & - & - & -- & 50.00 & $06-01-65$ & - & 15 & 15 & 1.0 & $08-10-88$ & 85 & 5.0 & 351 \\
\hline 100 & 30 & 6 & $58 / 88$ & 46.00 & 08-01-70 & 20 & - & - & - & $12-23-86$ & 78 & 5.2 & 371 \\
\hline 101 & - & - & $\cdots$ & - & - & - & -- & - & - & $08-11-88$ & 115 & 5.0 & 650 \\
\hline 170 & 26 & 6 & - & 91.00 & 07-01-71 & -- & .25 & 10 & -- & $12-22-86$ & 31 & 5.5 & 792 \\
\hline 162 & 42 & 4 & -- & 62.00 & $12-09-86$ & -- & - & -- & - & $12-09-86$ & 48 & 5.0 & 1148 \\
\hline 160 & 70 & 6 & $85 / 145$ & 81.30 & $12-09-86$ & 15 & - & - & - & $12-09-86$ & 116 & 6.1 & 1149 \\
\hline-- & -- & - & -- & - & $12-09-86$ & - & - & - & - & $12-09-86$ & 63 & 6.2 & 1150 \\
\hline 160 & 42 & 6 & $95 / 140$ & 86.90 & $12-10-86$ & 10 & -- & -- & - & $12-10-86$ & 264 & 6.7 & 1151 \\
\hline 500 & 23 & 6 & $115 / 360$ & 80.00 & $06-01-79$ & 1 & - & - & - & $12-10-86$ & 91 & 6.4 & 1152 \\
\hline 245 & 105 & 11 & 14/141/197/231 & 99.80 & $12-10-85$ & - & .07 & 15 & .5 & $12-10-86$ & 174 & 6.5 & 1153 \\
\hline 140 & 40 & 6 & $90 / 125$ & 25.20 & $12-11-86$ & 15 & -- & $-\cdot$ & -- & $12-11-85$ & 85 & 5.4 & 1154 \\
\hline 160 & 60 & 6 & 9/140/155 & - & - & 15 & -- & - & - & $12-11-86$ & 52 & 6.1 & 1155 \\
\hline 100 & 40 & 6 & $68 / 86$ & - & - & - & .18 & 12 & 2 & $12-11-86$ & 47 & 5.5 & 1156 \\
\hline- & -- & - & - & -. & -. & -- & -. & - & - & $12-22-86$ & 136 & 4.7 & 1157 \\
\hline-- & - & - & - & - & - & - & - & - & - & $12-23-86$ & 173 & 4.9 & 1158 \\
\hline 249 & - & - & - & 29.10 & $12-23-86$ & -. & - & - & -- & $12-23-86$ & 238 & 6.4 & 1159 \\
\hline 145 & 26 & 6 & $45 / 90 / 125$ & 31.00 & $06-01-80$ & - & .04 & 5 & 2 & $12-23-86$ & 168 & 6.2 & 1160 \\
\hline 300 & 40 & 6 & $65 / 150$ & 26.90 & $12-24-86$ & 4 & - & - & - & $12-24-86$ & 15 & 6.9 & 1161 \\
\hline 70 & -- & - & - & - & - & - & - & - & - & 07-21-87 & 80 & 5.2 & 1162 \\
\hline 230 & 121 & 6 & -- & - & - & 4 & - & -- & - & $07-21-87$ & 26 & 5.3 & 1163 \\
\hline 350 & 18 & 6 & - & 67.40 & $07-22-87$ & - & - & - & - & $07-22-87$ & 65 & 6.8 & 1164 \\
\hline 126 & 13 & 6 & 65 & 13.00 & $10-00-47$ & $<1$ & -. & - & - & $07-22-87$ & 145 & 4.8 & 1165 \\
\hline 99 & 25 & 6 & - & 58.20 & $07-22-87$ & 6 & -- & - & - & $07-23-87$ & 200 & 4.4 & 1166 \\
\hline 125 & 20 & 6 & -- & 48.80 & $07-23-87$ & - & -- & - & - & $07-23-87$ & 128 & 5.6 & 1167 \\
\hline 70 & - & - & - & -- & - & -- & - & - & - & $07-23-87$ & 250 & 7.3 & 1168 \\
\hline 300 & 20 & 6 & $200 / 220$ & 52.80 & $08-11-88$ & 5 & - & - & - & 08-11-88 & 30 & 5.2 & 1172 \\
\hline 230 & 126 & 6 & -- & 82.00 & $08-08-88$ & - & - & - & -- & $08-08-88$ & 24 & 5.5 & 1175 \\
\hline 240 & 60 & 6 & $126 / 185 / 227$ & 63.00 & $08-09-88$ & 7 & - & -- & - & $08-09-88$ & 89 & 5.3 & 1176 \\
\hline
\end{tabular}


Table 20. Records of wells and springs--Continued

\begin{tabular}{|c|c|c|c|c|c|c|c|c|c|c|c|}
\hline \multirow{2}{*}{$\begin{array}{l}\text { USGS } \\
\text { well } \\
\text { number } \\
\text { or spring }\end{array}$} & \multirow{2}{*}{\multicolumn{3}{|c|}{$\begin{array}{l}\frac{\text { Location }}{\text { Latitude Longitude }} \\
\text { (degrees) }\end{array}$}} & \multirow[b]{2}{*}{ Owner } & \multirow[b]{2}{*}{$\begin{array}{l}\text { Driller } \\
\text { license } \\
\text { number }\end{array}$} & \multirow[b]{2}{*}{$\begin{array}{c}\text { Year } \\
\text { drilled }\end{array}$} & \multicolumn{2}{|c|}{ Primary } & \multirow{2}{*}{$\begin{array}{c}\text { Altitude } \\
\text { of land } \\
\text { surface } \\
\text { (feet) }\end{array}$} & \multirow[b]{2}{*}{$\begin{array}{l}\text { Topo- } \\
\text { g־aphic } \\
\text { sotting }\end{array}$} & \multirow[b]{2}{*}{$\begin{array}{l}\text { Hydro- } \\
\text { geologic } \\
\text { unit }\end{array}$} \\
\hline & & & & & & & $\begin{array}{l}\text { Use } \\
\text { of } \\
\text { site }\end{array}$ & $\begin{array}{c}\text { Use } \\
\text { of } \\
\text { water }\end{array}$ & & & \\
\hline Yo.1177 & 400053 & 0763924 & Springettsbury & Landis, Leonard & 1706 & 1988 & $\mathbf{w}$ & $\mathbf{H}$ & 662 & S & 377CCKS \\
\hline 1178 & 400233 & 0763708 & Hellam & Ruppert, Donna & 0356 & 1986 & $\mathbf{W}$ & $\mathrm{H}$ & 751 & $\mathrm{~s}$ & $377 \mathrm{CCKS}$ \\
\hline 1179 & 400202 & 0763547 & Hellam & Myers, Henry & 0741 & 1986 & $\mathbf{w}$ & H & 770 & $\mathbf{H}$ & $377 \mathrm{CCKS}$ \\
\hline 1180 & 395123 & 0765656 & Heidelberg & Wright, W. & 0211 & 1981 & $\mathbf{W}$ & $\mathbf{H}$ & 1210 & $\mathbf{H}$ & 377CCKS \\
\hline 1181 & 395317 & 0765509 & Jackson & Niner, Jean & 1381 & 1978 & $\mathbf{W}$ & $\mathrm{H}$ & 825 & $\mathbf{H}$ & $377 \mathrm{CCKS}$ \\
\hline 1182 & 395235 & 0764737 & N. Codorus & Miller, Daniel & 0383 & 1984 & $\mathbf{W}$ & $\mathbf{H}$ & 723 & $\mathbf{H}$ & $377 \mathrm{CCKS}$ \\
\hline 1183 & 395926 & 0763323 & L. Windsor & Hamilton, Richard & -. & 1979 & $\mathbf{W}$ & $\mathbf{H}$ & 720 & $\mathbf{H}$ & 377CCKS \\
\hline 1184 & 400106 & 0763633 & Hellam & Carroll, Roy & - & 1986 & $\mathbf{W}$ & $\mathbf{H}$ & 710 & $\mathbf{S}$ & $377 \mathrm{CCKS}$ \\
\hline 1185 & 400207 & 0763724 & Hellam & Barbor, G. & 1515 & 1981 & $\mathbf{W}$ & $\mathrm{H}$ & 985 & $\mathbf{H}$ & $377 \mathrm{CCKS}$ \\
\hline 1186 & 400025 & 0764010 & Springettsbury & Mcclain, Linda & -- & 1980 & $\mathbf{W}$ & $\mathbf{H}$ & 881 & $\mathbf{H}$ & $377 \mathrm{CCKS}$ \\
\hline
\end{tabular}


Table 20. Records of wells and springs--Continued

\begin{tabular}{|c|c|c|c|c|c|c|c|c|c|c|c|c|c|}
\hline \multirow[b]{2}{*}{$\begin{array}{l}\text { Depth } \\
\text { of } \\
\text { well } \\
\text { (feet) }\end{array}$} & & & \multirow[b]{2}{*}{$\begin{array}{l}\text { Depth to } \\
\text { water-bearing } \\
\text { zone(s) } \\
\text { (feet) }\end{array}$} & \multirow[b]{2}{*}{$\begin{array}{l}\text { Water } \\
\text { level } \\
\text { (feet) }\end{array}$} & \multirow[b]{2}{*}{$\begin{array}{c}\text { Date } \\
\text { water } \\
\text { level } \\
\text { measured }\end{array}$} & \multirow[b]{2}{*}{$\begin{array}{c}\text { Reported } \\
\text { yield } \\
\text { (galy } \\
\text { min) }\end{array}$} & \multicolumn{3}{|c|}{ Measured vield } & \multicolumn{3}{|c|}{ Field water quality } & \multirow[b]{2}{*}{$\begin{array}{c}\text { USGS } \\
\text { well } \\
\text { number } \\
\text { or spring }\end{array}$} \\
\hline & \multicolumn{2}{|c|}{ Casine } & & & & & $\begin{array}{c}\text { Specific } \\
\text { capacity } \\
\text { [(gal } \\
\mathrm{min}) / \mathrm{ft}]\end{array}$ & $\begin{array}{c}\text { Dis- } \\
\text { charge } \\
\text { (gal/ } \\
\text { min) }\end{array}$ & $\begin{array}{c}\text { Pumping } \\
\text { period } \\
\text { (hours) }\end{array}$ & $\begin{array}{c}\text { Date } \\
\text { measured }\end{array}$ & $\begin{array}{l}\text { Specific } \\
\text { conduc- } \\
\text { tance } \\
(\mu \mathrm{S} / \mathrm{cm})\end{array}$ & $\begin{array}{c}\text { pH } \\
\text { (stan- } \\
\text { dard } \\
\text { units) }\end{array}$ & \\
\hline- & - & - & - & 50.70 & $08-09-88$ & - & - & - & - & $08-09-88$ & 41 & 5.9 & 1177-YO \\
\hline 160 & 52 & 6 & -- & 39.20 & $08-09-88$ & 3 & -. & -. & - & $08-09-88$ & 34 & 5.1 & 1178 \\
\hline 300 & 40 & 6 & $210 / 290$ & 61.00 & $08-09-88$ & 5 & - & - & -- & $08-09-88$ & 122 & 4.7 & 1179 \\
\hline 220 & 27 & 6 & $128 / 185$ & 96.60 & $08-10-88$ & -- & 0.08 & 10 & 1 & $08-10-88$ & 38 & 5.5 & 1180 \\
\hline-- & - & - & - & 50.10 & $08-10-88$ & -- & - & - & - & $08-10-88$ & 58 & 5.6 & 1181 \\
\hline 167 & 34 & 6 & $73 / 158$ & 80.20 & 08-10-88 & 4 & - & - & - & $08-10-88$ & 45 & 5.3 & 1182 \\
\hline 230 & - & - & - & - & -- & - & - & - & - & $08-11-88$ & 180 & 5.7 & 1183 \\
\hline 180 & - & - & 115 & 24.20 & $09-07-88$ & - & - & - & - & $09-07-88$ & 93 & 4.6 & 1184 \\
\hline 160 & 37 & 6 & $120 / 145$ & 95.00 & $07-00-81$ & - & .17 & 9 & 2.5 & $09-07-88$ & 50 & 4.8 & 1185 \\
\hline- & - & - & - & - & - & - & - & - & - & $09-07-88$ & 50 & 4.9 & 1186 \\
\hline
\end{tabular}


Table 21. Physical properties and chemical analyses for major ions, selected minor ions, nutrients, and dissolved organic carbon in ground water in the Chickies Quartzite and adjacent geologic units. Geologic unit codes are explained at beginning of table 20.

$\left[{ }^{\circ} \mathrm{C}\right.$, degrees Celsius; $\mu \mathrm{S} / \mathrm{cm}$, microsiemens per centimeter at 25 Celsius; $\mathrm{mg} / \mathrm{L}$, milligrams per liter; $\mu \mathrm{g} / \mathrm{L}$, micrograms per liter; $<$, less than; --, no data]

\begin{tabular}{|c|c|c|c|c|c|c|c|c|c|c|c|c|c|}
\hline $\begin{array}{l}\text { USGS } \\
\text { well } \\
\text { number }\end{array}$ & $\begin{array}{l}\text { Geo- } \\
\text { logic } \\
\text { unit }\end{array}$ & Date & $\begin{array}{l}\mathrm{pH} \\
\text { (stand- } \\
\text { ard } \\
\text { units) }\end{array}$ & $\begin{array}{c}\text { Temper- } \\
\text { ature, } \\
\text { water } \\
\left({ }^{\circ} \mathrm{C}\right)\end{array}$ & $\begin{array}{l}\text { Spe- } \\
\text { cific } \\
\text { con- } \\
\text { duct- } \\
\text { ance } \\
(\mu \mathrm{S} / \mathrm{cm})\end{array}$ & $\begin{array}{c}\text { Oxygen, } \\
\text { dis- } \\
\text { solved } \\
(\mathrm{mg} / \mathrm{L})\end{array}$ & $\begin{array}{c}\text { Alka- } \\
\text { linity } \\
\text { field } \\
(\mathrm{mg} / \mathrm{L} \\
\left.\text { as } \mathrm{CaCO}_{3}\right)\end{array}$ & $\begin{array}{c}\text { Cal- } \\
\text { cium, } \\
\text { dis- } \\
\text { solved } \\
\text { (mg/L } \\
\text { as Ca) }\end{array}$ & $\begin{array}{l}\text { Magne- } \\
\text { sium, } \\
\text { dis } \\
\text { solved } \\
\text { (mg/L } \\
\text { as } \mathrm{Mg} \text { ) }\end{array}$ & $\begin{array}{l}\text { Sodium, } \\
\text { dis- } \\
\text { solved } \\
\text { (mg/L } \\
\text { as } N a \text { ) }\end{array}$ & $\begin{array}{l}\text { Potas- } \\
\text { sium, } \\
\text { dis- } \\
\text { solved } \\
\text { (mg/L } \\
\text { as K) }\end{array}$ & $\begin{array}{l}\text { Chlo- } \\
\text { ride, } \\
\text { dis- } \\
\text { solved } \\
\text { (mg/L. } \\
\text { as } \mathrm{Cl}\end{array}$ & $\begin{array}{c}\text { Sul- } \\
\text { fate, } \\
\text { dis- } \\
\text { solved } \\
\text { (mg/L } \\
\text { as SO } \text { SO }_{4}\end{array}$ \\
\hline
\end{tabular}

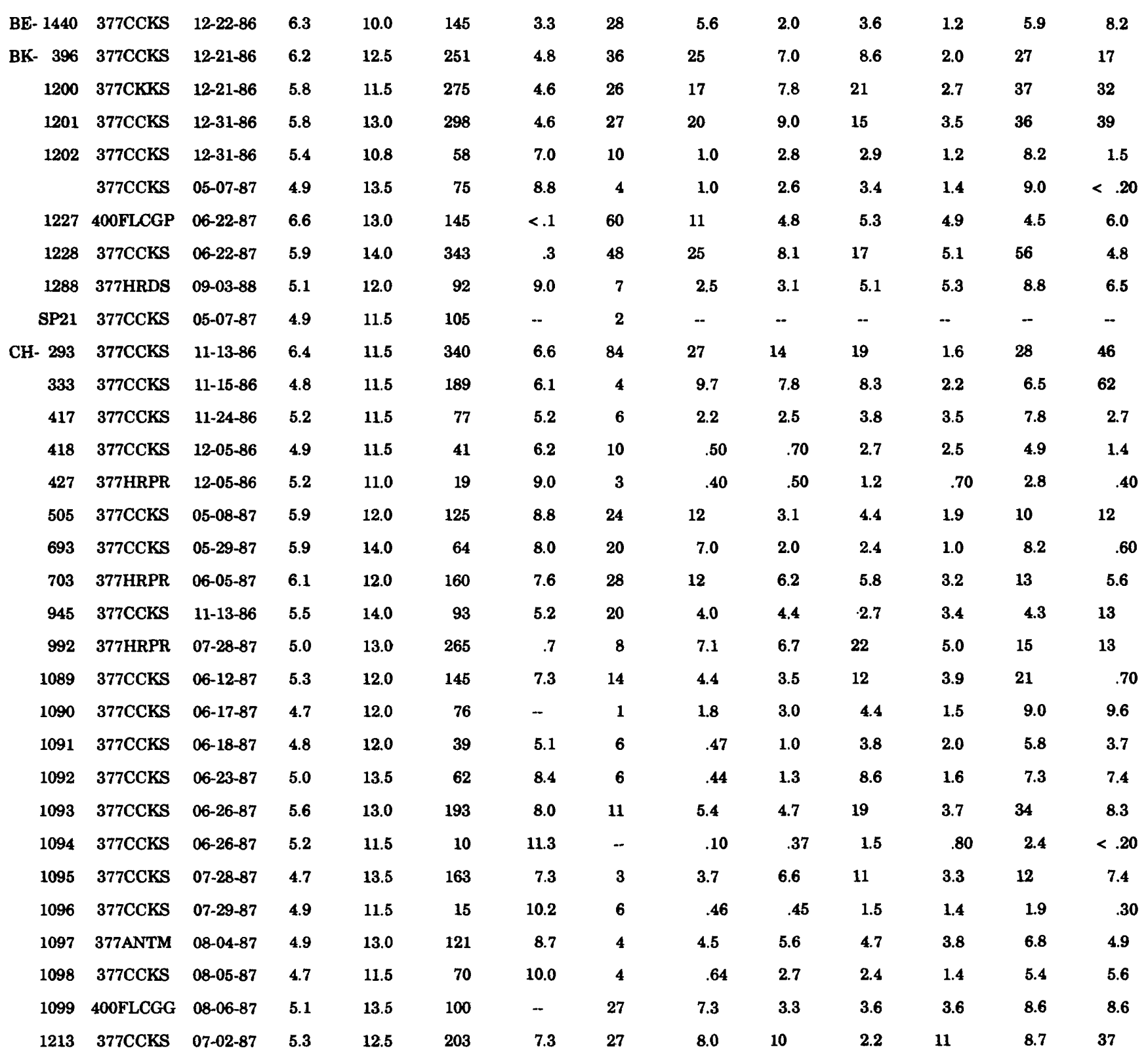


Table 21. Physical properties and chemical analyses for major ions, selected minor ions, nutrients, and dissolved organic carbon in ground water in the Chickies Quartzite and adjacent geologic units. Geologic unit codes are explained at breginning of table 20--Continued

\begin{tabular}{|c|c|c|c|c|c|c|c|c|c|c|c|c|c|}
\hline $\begin{array}{l}\text { Fluo- } \\
\text { ride, } \\
\text { dis- } \\
\text { solved } \\
\text { (mg/L } \\
\text { as F) }\end{array}$ & $\begin{array}{l}\text { Silica, } \\
\text { dis- } \\
\text { solved } \\
(\mathrm{mg} / \mathrm{L} \\
\left.\text { as } \mathrm{SiO}_{2}\right)\end{array}$ & $\begin{array}{l}\text { Iron, } \\
\text { total } \\
\text { recov- } \\
\text { erable } \\
(\mu g / \mathrm{L} \\
\text { as Fe) }\end{array}$ & $\begin{array}{l}\text { Iron, } \\
\text { dis- } \\
\text { solved } \\
\text { (ug/L } \\
\text { as Fe) }\end{array}$ & $\begin{array}{c}\text { Manga- } \\
\text { nese, } \\
\text { dis- } \\
\text { solved } \\
(\mu g / L \\
\text { as } \mathrm{Mn} \text { ) }\end{array}$ & $\begin{array}{l}\text { Barium, } \\
\text { dis- } \\
\text { solved } \\
(\mu \mathrm{g} / \mathrm{L} \\
\text { as } \mathrm{Ba})\end{array}$ & $\begin{array}{l}\text { Boron, } \\
\text { dis- } \\
\text { solved } \\
\text { ( } \mu \mathrm{g} / \mathrm{L} \\
\text { as B) }\end{array}$ & $\begin{array}{c}\text { Solids, } \\
\text { residue } \\
\text { at } 180^{\circ} \mathrm{C} \\
\text { dis- } \\
\text { solved } \\
\text { (mg/L) }\end{array}$ & $\begin{array}{l}\text { Nitro- } \\
\text { gen, } \\
\text { ammonia, } \\
\text { dis- } \\
\text { solved } \\
\text { (mg/L } \\
\text { as } N \text { ) }\end{array}$ & $\begin{array}{l}\text { Nitro- } \\
\text { gen, } \\
\text { nitrite, N } \\
\text { dis- } \\
\text { solved } \\
\text { (mg/L } \\
\text { as N) }\end{array}$ & $\begin{array}{c}\text { Nitro- } \\
\text { gen, } \\
\mathrm{NO}_{2}+\mathrm{NO}_{3} \\
\text { dis- } \\
\text { solved } \\
\text { (mg/L } \\
\text { as } \mathrm{N} \text { ) }\end{array}$ & $\begin{array}{l}\text { Phos- } \\
\text { phorus, } \\
\text { ortho, } \\
\text { dis- } \\
\text { solved } \\
\text { (mg/L } \\
\text { as P) }\end{array}$ & $\begin{array}{c}\text { Carbon, } \\
\text { organic, } \\
\text { dis- } \\
\text { solved } \\
\text { (mg/L } \\
\text { as C) }\end{array}$ & $\begin{array}{c}\text { USGS } \\
\text { well } \\
\text { number }\end{array}$ \\
\hline$<0.10$ & 6.6 & 2,800 & 2,600 & 400 & 200 & - & 85 & - & -- & -- & - & 2.1 & 1440-BE \\
\hline$<.10$ & 24 & 80 & 8 & 3 & 35 & - & 156 & - & - & -- & - & .5 & 396-BK \\
\hline .10 & 12 & 2,600 & 75 & 11 & 95 & - & 147 & - & - & -- & - & .7 & 1200 \\
\hline$<.10$ & 21 & 50 & 20 & $<10$ & 300 & -- & 187 & - & .- & - & - & .7 & 1201 \\
\hline$<.10$ & 3.4 & 3,000 & 2,600 & 60 & 100 & -- & 35 & - & - & - & - & 1.1 & 1202 \\
\hline$<.10$ & 6.8 & 920 & 730 & 25 & 58 & -- & 40 & - & - & - & - & -- & \\
\hline .30 & 33 & 5,600 & 5,000 & 250 & 94 & - & 97 & - & - & - & - & 2.0 & 1227 \\
\hline .20 & 20 & 1,400 & 180 & 160 & 200 & - & 205 & - & - & - & - & - & 1228 \\
\hline .10 & 14 & 20 & 13 & 23 & 110 & 10 & 77 & $<0.010$ & $<0.010$ & 3.00 & 0.002 & .8 & 1288 \\
\hline- & -- & -- & -. & .- & -. & - & - & - & - & - & - & - & SP21 \\
\hline$<.10$ & 12 & 30 & 11 & $<1$ & 42 & - & 206 & - & - & - & -- & 1.8 & 293-CH \\
\hline .10 & 8.8 & 1,300 & 73 & 190 & 130 & -. & 109 & - & - & -- & - & 2.5 & 333 \\
\hline$<.10$ & 10 & 170 & 5 & 22 & 80 & - & 46 & -- & - & - & - & .6 & 417 \\
\hline$<.10$ & 9.0 & 10 & 5 & 15 & 55 & - & 25 & - & - & - & - & .8 & 418 \\
\hline$<.10$ & 6.4 & 10,000 & 13 & 4 & 13 & - & 10 & - & - & - & -- & .7 & 427 \\
\hline$<.10$ & 18 & 40 & 5 & 12 & 29 & - & 80 & -. & - & - & - & .6 & 505 \\
\hline .20 & 18 & 80 & 6 & 2 & 10 &.- & 48 & - & -. & - & .- & .5 & 693 \\
\hline .10 & 21 & 1,300 & 13 & 7 & 35 & - & 112 & - & - & - & - & .5 & 703 \\
\hline$<.10$ & 8.7 & 80 & 16 & 11 & 37 & -. & 51 & - & - & - & - & .9 & 945 \\
\hline .10 & 8.3 & 20 & 12 & 410 & 180 & - & 152 & - & - & - & - & 1.5 & 992 \\
\hline$<.10$ & 12 & $<10$ & 5 & 34 & 370 & - & 76 & - & - & - & - & .7 & 1089 \\
\hline .20 & 6.7 & 60 & 8 & 120 & 83 & - & 41 & - & - & - & - & 1.6 & 1090 \\
\hline .10 & 10 & 2,800 & 60 & 25 & 48 & - & 29 & - & -- & - & - & .6 & 1091 \\
\hline .10 & 8.3 & 5,000 & 120 & 20 & 110 & - & 43 & - & - & - & - & 1.8 & 1092 \\
\hline .10 & 12 & 100 & 16 & 6 & 22 & - & 99 & - & - & - & - & .6 & 1093 \\
\hline .10 & 6.0 & 240 & 520 & 20 & 10 & - & 10 & - & - & - & - & .7 & 1094 \\
\hline .10 & 9.8 & 1,000 & 22 & 86 & 200 & - & 108 & - & - & - & - & 1.0 & 1095 \\
\hline .10 & 8.0 & 80 & 5 & 3 & 13 & - & 12 & - & - & -- & - & .5 & 1096 \\
\hline .10 & 11 & $<10$ & 10 & 23 & 36 & - & 87 & - & - & - & - & .6 & 1097 \\
\hline .10 & 7.1 & 51,000 & 57 & 8 & 38 & - & 37 & - & - & - & - & 1.2 & 1098 \\
\hline .10 & 15 & - & 36 & 7 & - & - & 78 & - & - & - & - & - & 1099 \\
\hline .20 & 7.0 & 40 & 15 & 79 & 100 & - & 125 & - & - & - & - & 1.5 & 1213 \\
\hline
\end{tabular}


Table 21. Physical properties and chemical analyses for major ions, selected minor ions, nutrients, and dissolved ormanic carbon in ground water in the Chickies Quartzite and adjacent geologic units. Geologic unit codes are explained at traginning of table 20--Continued

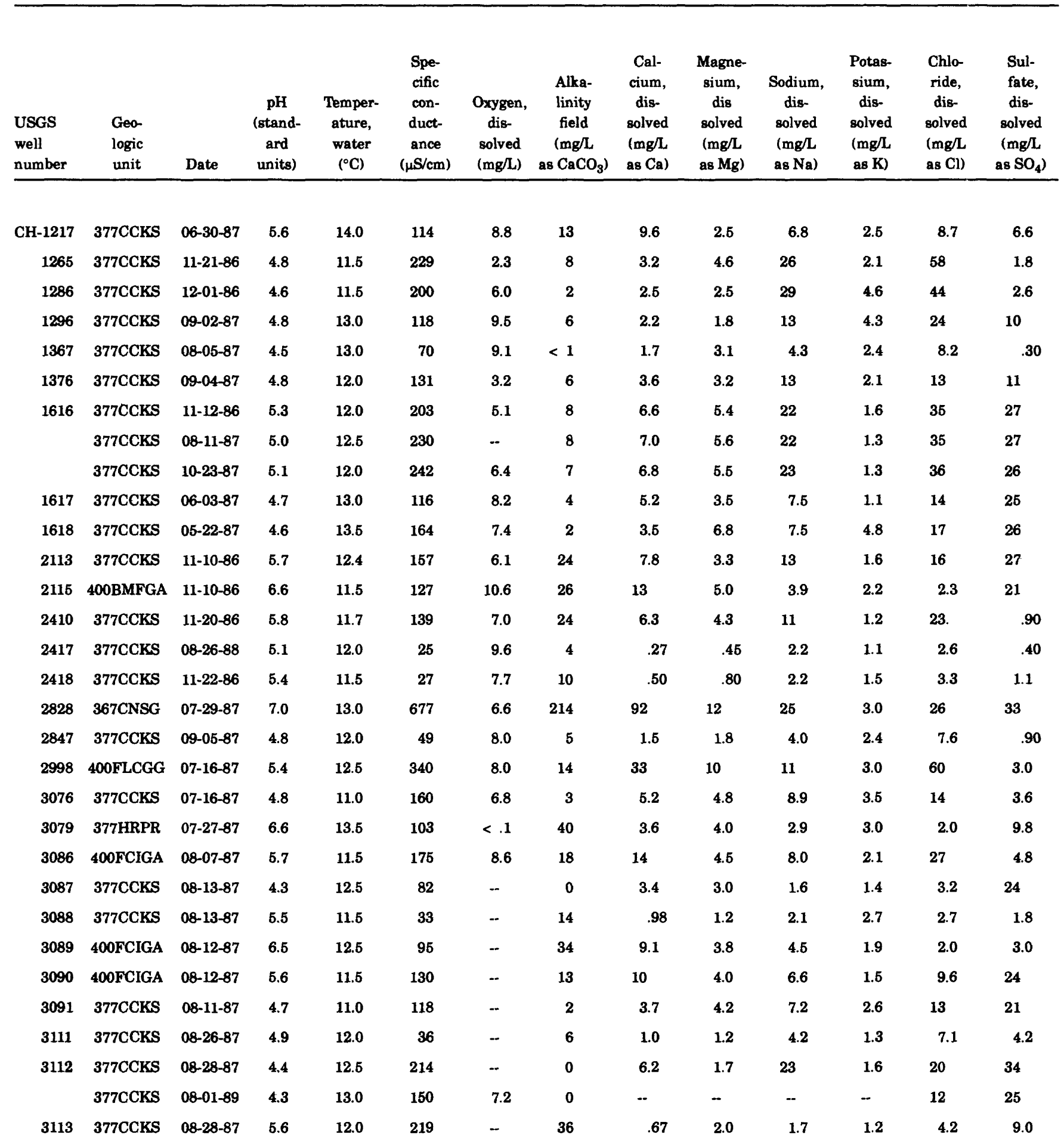


Table 21. Physical properties and chemical analyses for major ions, selected minor ions, nutrients, and dissolved organic carbon in ground water in the Chickies Quartzite and adjacent geologic units. Geologic unit codes are explained at baginning of table 20--Continued

\begin{tabular}{|c|c|c|c|c|c|c|c|c|c|c|c|c|c|}
\hline $\begin{array}{l}\text { Fluo- } \\
\text { ride, } \\
\text { dis- } \\
\text { solved } \\
\text { (mg/L } \\
\text { as F) }\end{array}$ & $\begin{array}{c}\text { Silica, } \\
\text { dis- } \\
\text { solved } \\
(\mathrm{mg} / \mathrm{L} \\
\text { as } \mathrm{SiO}_{2} \text { ) }\end{array}$ & $\begin{array}{l}\text { Iron, } \\
\text { total } \\
\text { recov- } \\
\text { erable } \\
\text { ( } \mu \mathrm{g} / \mathrm{L} \\
\text { as Fe) }\end{array}$ & $\begin{array}{c}\text { Iron, } \\
\text { dis- } \\
\text { solved } \\
(\mu \mathrm{g} / \mathrm{L} \\
\text { as Fe) }\end{array}$ & $\begin{array}{l}\text { Manga- } \\
\text { nese, } \\
\text { dis- } \\
\text { solved } \\
\text { ( } \mu \mathrm{g} / \mathrm{L} \\
\text { as } \mathrm{Mn} \text { ) }\end{array}$ & $\begin{array}{c}\text { Barium, } \\
\text { dis- } \\
\text { solved } \\
(\mu \mathrm{g} / \mathrm{L} \\
\text { as Ba) }\end{array}$ & $\begin{array}{c}\text { Boron, } \\
\text { dis- } \\
\text { solved } \\
(\mu g / L \\
\text { as B) }\end{array}$ & $\begin{array}{c}\text { Solids, } \\
\text { residue } \\
\text { at } 180^{\circ} \mathrm{C} \\
\text { dis- } \\
\text { solved } \\
(\mathrm{mg} / \mathrm{L})\end{array}$ & $\begin{array}{l}\text { Nitro- } \\
\text { gen, } \\
\text { ammonia, } \\
\text { dis- } \\
\text { solved } \\
\text { (mg/L } \\
\text { as } N \text { ) }\end{array}$ & $\begin{array}{l}\text { Nitro- } \\
\text { gen, } \\
\text { nitrite, } \\
\text { dis- } \\
\text { solved } \\
\text { (mg/L } \\
\text { as N) }\end{array}$ & $\begin{array}{c}\text { Nitro- } \\
\text { gen, } \\
\mathrm{NO}_{2}+\mathrm{NO}_{3} \\
\text { dis- } \\
\text { solved } \\
\text { (mg/L } \\
\text { as } \mathrm{N} \text { ) }\end{array}$ & $\begin{array}{l}\text { Phos- } \\
\text { phorus, } \\
\text { ortho, } \\
\text { dis- } \\
\text { solved } \\
\text { (mg/L } \\
\text { as P) }\end{array}$ & $\begin{array}{l}\text { Carbon, } \\
\text { organic, } \\
\text { dis- } \\
\text { solved } \\
(\mathrm{mg} / \mathrm{L} \\
\text { as } \mathrm{C})\end{array}$ & $\begin{array}{c}\text { USGS } \\
\text { well } \\
\text { number }\end{array}$ \\
\hline 0.10 & 22 & 90 & 15 & 6 & 60 & -- & 91 & -- & - & -- & - & 0.9 & $1217-\mathrm{CH}$ \\
\hline$<.10$ & 7.1 & 1,600 & 1,700 & 38 & 190 & - & 113 & - & -- & -- & - & 2.0 & 1265 \\
\hline$<.10$ & 9.0 & 180 & 20 & 95 & 320 & - & 116 & -. & - & - & -- & .9 & 1286 \\
\hline .10 & 9.6 & 700 & 100 & 20 & 150 & - & 74 & - & - & -- & - & 1.3 & 1296 \\
\hline .10 & 7.4 & 30 & 12 & 32 & 120 & -. & 42 & - & -. & - & - & .6 & 1367 \\
\hline .10 & 7.0 & 80 & 9 & 290 & 91 & -- & 70 & - & -- & -- & - & 1.5 & 1376 \\
\hline$<.10$ & 5.7 & 290 & 130 & 40 & 42 & -- & 117 & -- & -- & -- & - & 1.2 & 1616 \\
\hline .10 & 5.8 & 80 & 70 & 41 & 40 & - & 116 & - & -- & -. & - & 1.0 & \\
\hline .10 & 5.7 & 140 & 95 & 43 & 40 & - & 112 & -- & - & -- & - & - & \\
\hline .10 & 6.5 & 310 & 140 & 100 & 84 & - & 59 & -- & - & - & - & 1.7 & 1617 \\
\hline .30 & 9.3 & 330 & 610 & 200 & 290 & - & 88 & - & - & -. & - & 2.8 & 1618 \\
\hline .10 & 4.7 & 4,600 & 280 & 39 & 50 & -- & 87 & $\cdots$ & -- & - & - & -- & 2113 \\
\hline$<.10$ & 19 & 4,000 & 19 & 3 & 39 & - & 89 & - & -. & - & -- & .9 & 2115 \\
\hline$<.10$ & 16 & 210 & 68 & 14 & 76 & -- & 85 & - & - & -- & -- & - & 2410 \\
\hline$<.10$ & 7.9 & 90 & 10 & 4 & 15 & $<10$ & 17 & $<0.010$ & $<0.010$ & 0.590 & 0.001 & .7 & 2417 \\
\hline$<.10$ & 8.8 & 1,200 & 51 & 11 & 34 & - & 16 & - & - & - & -- & .7 & 2418 \\
\hline .10 & 13 & 110 & 6 & 2 & 23 & -- & 388 & - & - & - & - & .8 & 2828 \\
\hline$<.10$ & 9.7 & 340 & 73 & 17 & 70 & -- & 39 & - & - & -- & -- & .7 & 2847 \\
\hline .10 & 19 & 30 & 10 & 11 & 120 & -- & 298 & .020 & $<.010$ & 14.0 & $<.010$ & -- & 2998 \\
\hline .20 & 9.7 & 20 & 11 & 440 & 170 & - & 85 & - & -- & - & - & - & 3076 \\
\hline .20 & 19 & 11,000 & 10,000 & 880 & 20 & -- & 54 & -- & - & -- & - & .6 & 3079 \\
\hline .10 & 18 & 180 & 8 & 7 & 100 & -- & 126 & - & - & - & - & .7 & 3086 \\
\hline .20 & 5.8 & .40 & 9 & 140 & 72 & -- & 47 & -- & - & - & - & 1.9 & 3087 \\
\hline .10 & 10 & 19,000 & 2,500 & 180 & 45 & -- & 20 & -- & - & - & - & .8 & 3088 \\
\hline .10 & 21 & 5,300 & 4 & 8 & 60 & - & 67 & -. & - & -- & - & .3 & 3089 \\
\hline .10 & 19 & $<10$ & $<$ & 2 & 47 & -- & 83 & - & -- & - & - & .9 & 3090 \\
\hline .20 & 8.0 & $<\quad 10$ & $<$ & 85 & 120 & - & 68 & -- & - & - & - & 1.8 & 3091 \\
\hline$<.10$ & 7.3 & 480 & $<3$ & 24 & 38 & - & 28 & - & - & - & - & 1.2 & 3111 \\
\hline .20 & 4.4 & 740 & 7 & 77 & 46 & -- & 107 & -- & -- & - & - & 5.0 & 3112 \\
\hline- & - & - & 90 & 60 & -- & - & 110 & $<.010$ & $<.010$ & 2.90 & - & - & \\
\hline .10 & 8.2 & - & 200 & 47 & 48 & - & 23 & -- & -- & -- & - & 10 & 3113 \\
\hline
\end{tabular}


Table 21. Physical properties and chemical analyses for major ions, selected minor ions, nutrients, and dissolved organic carbon in ground water in the Chickies Quartzite and adjacent geologic units. Geologic unit codes are explained at beginning of table 20--Continued

\begin{tabular}{|c|c|c|c|c|c|c|c|c|c|c|c|c|c|}
\hline $\begin{array}{l}\text { USGS } \\
\text { well } \\
\text { number }\end{array}$ & $\begin{array}{l}\text { Geo- } \\
\text { logic } \\
\text { unit }\end{array}$ & Date & $\begin{array}{c}\text { pH } \\
\text { (stand- } \\
\text { ard } \\
\text { units) }\end{array}$ & $\begin{array}{c}\text { Temper- } \\
\text { ature, } \\
\text { water } \\
\left({ }^{\circ} \mathrm{C}\right)\end{array}$ & $\begin{array}{l}\text { Spe- } \\
\text { cific } \\
\text { con- } \\
\text { duct- } \\
\text { ance } \\
(\mu \mathrm{S} / \mathrm{cm})\end{array}$ & $\begin{array}{l}\text { Oxygen, } \\
\text { dis- } \\
\text { solved } \\
\text { (mg/L) }\end{array}$ & $\begin{array}{c}\text { Alka- } \\
\text { linity } \\
\text { field } \\
(\mathrm{mg} / \mathrm{L} \\
\left.\text { as } \mathrm{CaCO}_{3}\right)\end{array}$ & $\begin{array}{c}\text { Cal- } \\
\text { cium, } \\
\text { dis- } \\
\text { solved } \\
(\mathrm{mg} / \mathrm{L} \\
\text { as Ca) }\end{array}$ & $\begin{array}{c}\text { Magne- } \\
\text { sium, } \\
\text { dis } \\
\text { solved } \\
\text { (mg/L } \\
\text { as } \mathbf{M g} \text { ) }\end{array}$ & $\begin{array}{c}\text { Sodium, } \\
\text { dis- } \\
\text { solved } \\
\text { (mg/L } \\
\text { as } \mathrm{Na} \text { ) }\end{array}$ & $\begin{array}{c}\text { Potas- } \\
\text { sium, } \\
\text { dis- } \\
\text { solved } \\
(\mathrm{mg} / \mathrm{L} \\
\text { as } \mathrm{K})\end{array}$ & $\begin{array}{l}\text { Chlo- } \\
\text { ride. } \\
\text { dis- } \\
\text { solved } \\
\text { (mg/. } \\
\text { as Cl) }\end{array}$ & $\begin{array}{c}\text { Sul- } \\
\text { fate, } \\
\text { dis- } \\
\text { solved } \\
(\mathrm{mg} / \mathrm{L} \\
\left.\text { as } \mathrm{SO}_{4}\right)\end{array}$ \\
\hline
\end{tabular}

\begin{tabular}{|c|c|c|c|c|c|c|c|c|c|c|c|c|c|}
\hline CH-3114 & $377 \mathrm{CCKS}$ & $08-29-87$ & 4.7 & 12.5 & 296 & -- & 3 & 3.3 & 3.8 & 40 & 2.1 & 83 & 3.9 \\
\hline 3117 & 400FCIGA & $08-31-87$ & 5.3 & 12.0 & 77 & - & 14 & 5.3 & 2.7 & 5.2 & 1.1 & 6.6 & 17 \\
\hline 3122 & $377 \mathrm{CCKS}$ & $09-04-87$ & 6.2 & 11.0 & 70 & -- & 26 & 6.5 & 1.9 & 2.2 & 3.6 & 2.3 & 1.9 \\
\hline 3123 & 377CCKS & $09-02-87$ & 5.0 & 12.0 & 42 & -- & 7 & 1.9 & 2.6 & 2.2 & 1.2 & 3.2 & 9.2 \\
\hline 3124 & $377 \mathrm{CCKS}$ & $09-02-87$ & 4.6 & 12.0 & 38 & -- & 3 & 5.9 & 5.7 & 7.7 & 1.4 & 9.7 & 45 \\
\hline 3125 & $377 \mathrm{CCKS}$ & $09-01-87$ & 4.3 & 12.5 & 271 & - & 0 & 5.2 & 3.1 & 23 & 3.2 & 18 & 41 \\
\hline 3126 & $377 \mathrm{CCKS}$ & $09-01-87$ & 5.3 & 12.0 & 16 & -- & 7 & .49 & .49 & 1.3 & 2.2 & 2.1 & 1.7 \\
\hline 3127 & 377CCKS & $09-01-87$ & 5.3 & 12.5 & 165 & - & 18 & 6.8 & 3.9 & 12 & 9.7 & 12 & 18 \\
\hline 3128 & 377CCKS & $09-03-87$ & 4.3 & 12.5 & 68 & -- & 0 & 2.6 & 2.4 & 1.6 & .90 & 3.1 & 23 \\
\hline 3131 & 377CCKS & $09-04-87$ & 5.2 & 11.5 & 16 & -- & 7 & .50 & .42 & 1.7 & 1.7 & 1.8 & .70 \\
\hline 3132 & $377 \mathrm{CCKS}$ & $09-03-87$ & 4.4 & 12.0 & 304 & - & 0 & 5.9 & 6.2 & 33 & 1.9 & 42 & 28 \\
\hline 3133 & 377CCKS & $10-21-87$ & 4.8 & 11.0 & 19 & 5.5 & 4 & .31 & .40 & 2.3 & 1.6 & 2.6 & 2.0 \\
\hline 3135 & 377CCKS & $09-05-87$ & 5.1 & 11.5 & 152 & 7.5 & 10 & 6.2 & 3.3 & 14 & 1.7 & 29 & 1.0 \\
\hline 3136 & 377HRPR & $09-08-87$ & 4.9 & 12.5 & 150 & 7.5 & 4 & 3.2 & 3.1 & 15 & 2.8 & 24 & 12 \\
\hline 3160 & 377CCKS & $08-22-88$ & 5.1 & 13.0 & 37 & 6.6 & 7 & .45 & .59 & 3.3 & 1.6 & 6.0 & 1.4 \\
\hline 3166 & 377CCKS & $10-19-87$ & 5.1 & 12.0 & 23 & -- & 3 & .53 & .87 & 3.0 & .70 & 6.0 & .20 \\
\hline 3168 & 377CCKS & $09-29-87$ & 4.8 & 12.5 & 114 & 9.4 & -- & 5.4 & 4.6 & 3.3 & 2.7 & 5.6 & 31 \\
\hline 3189 & $377 \mathrm{CCKS}$ & $08-30-88$ & 4.9 & 11.6 & 37 & 9.8 & 2.5 & .33 & 1.1 & 2.1 & 1.9 & 3.1 & .40 \\
\hline 3213 & $377 \mathrm{CCKS}$ & $10-21-87$ & 5.3 & 11.5 & 116 & 9.0 & 7 & 5.9 & 3.5 & 7.3 & 2.2 & 7.5 & 22 \\
\hline 3214 & $377 \mathrm{CCKS}$ & $10-22-87$ & 4.6 & 12.5 & 226 & 8.7 & 1 & 4.0 & 7.4 & 18 & 2.0 & 39 & 15 \\
\hline 3215 & $377 \mathrm{CCKS}$ & $10-23-87$ & 5.3 & 12.5 & 465 & 7.8 & 18 & 7.1 & 8.0 & 52 & 3.3 & 100 & 14 \\
\hline \multirow[t]{2}{*}{3219} & 377CCKS & $06-16-88$ & 5.4 & 13.0 & 44 & 10.0 & 6 & .44 & 1.6 & 1.6 & - & -- & -- \\
\hline & $377 \mathrm{CCKS}$ & $08-23-88$ & 4.5 & 13.5 & 44 & 10.6 & 0 & .58 & 2.1 & .90 & 1.4 & 1.8 & 10 \\
\hline 3301 & 400FMFG & $06-16-88$ & 5.3 & 11.5 & 34 & 8.1 & 11 & 1.5 & 1.4 & 1.9 & .80 & 2.8 & .80 \\
\hline 3315 & 377CCKS & $09-01-88$ & 4.9 & 13.0 & 58 & 9.8 & 2 & 2.5 & 2.2 & 1.2 & 1.0 & 1.9 & 15 \\
\hline 3325 & 377CCKS & $08-16-88$ & 4.6 & 12.0 & 130 & 7.2 & 1 & 5.1 & 5.5 & 3.3 & 3.1 & 6.0 & 14 \\
\hline 3326 & 377CCKS & $08-16-88$ & 6.4 & 11.5 & 92 & 5.5 & 32 & 6.7 & 3.7 & 2.9 & 4.6 & 2.6 & .60 \\
\hline 3327 & 377CCKS & $08-26-88$ & 4.4 & 16.5 & 77 & 10.4 & 0 & 1.5 & 2.3 & 1.5 & 1.4 & 3.2 & 17 \\
\hline 3328 & $377 \mathrm{CCKS}$ & $08-26-88$ & 5.3 & 13.0 & 53 & 8.0 & 6 & 1.8 & 1.4 & 4.0 & 1.5 & 6.0 & $<.20$ \\
\hline 3329 & 377CCKS & $08-22-88$ & 5.0 & 12.0 & 36 & 9.0 & 3 & .59 & 1.0 & 2.6 & 3.1 & 5.5 & 2.6 \\
\hline
\end{tabular}


Table 21. Physical properties and chemical analyses for major ions, selected minor ions, nutrients, and dissolved orçanic carbon in ground water in the Chickies Quartzite and adjacent geologic units. Geologic unit codes are explained at treginning of table 20--Continued

\begin{tabular}{|c|c|c|c|c|c|c|c|c|c|c|c|c|c|}
\hline $\begin{array}{l}\text { Fluo- } \\
\text { ride, } \\
\text { dis- } \\
\text { solved } \\
\text { (mg/L } \\
\text { as F) }\end{array}$ & $\begin{array}{c}\text { Silica, } \\
\text { dis- } \\
\text { solved } \\
(\mathrm{mg} / \mathrm{L} \\
\left.\text { as } \mathrm{SiO}_{2}\right)\end{array}$ & $\begin{array}{l}\text { Iron, } \\
\text { total } \\
\text { recov- } \\
\text { erable } \\
(\mu \mathrm{g} / \mathrm{L} \\
\text { as } \mathrm{Fe})\end{array}$ & $\begin{array}{l}\text { Iron, } \\
\text { dis- } \\
\text { solved } \\
(\mu \mathrm{g} / \mathrm{L} \\
\text { as } \mathrm{Fe} \text { ) }\end{array}$ & $\begin{array}{l}\text { Manga- } \\
\text { nese, } \\
\text { dis- } \\
\text { solved } \\
\text { ( } \mu \mathrm{g} / \mathrm{L} \\
\text { as } \mathrm{Mn} \text { ) }\end{array}$ & $\begin{array}{l}\text { Barium, } \\
\text { dis- } \\
\text { solved } \\
(\mu \mathrm{g} / \mathrm{L} \\
\text { as } \mathrm{Ba})\end{array}$ & $\begin{array}{l}\text { Boron, } \\
\text { dis- } \\
\text { solved } \\
(\mu \mathrm{g} / \mathrm{L} \\
\text { as B) }\end{array}$ & $\begin{array}{c}\text { Solids, } \\
\text { residue } \\
\text { at } 180{ }^{\circ} \mathrm{C} \\
\text { dis- } \\
\text { solved } \\
(\mathrm{mg} / \mathrm{L})\end{array}$ & $\begin{array}{c}\text { Nitro- } \\
\text { gen, } \\
\text { ammonia, } \\
\text { dis- } \\
\text { solved } \\
\text { (mg/L } \\
\text { as N) }\end{array}$ & $\begin{array}{l}\text { Nitro- } \\
\text { gen, } \\
\text { nitrite, } \\
\text { dis- } \\
\text { solved } \\
\text { (mg/L } \\
\text { as N) }\end{array}$ & $\begin{array}{c}\text { Nitro- } \\
\text { gen, } \\
\mathrm{NO}_{2}+\mathrm{NO}_{3} \\
\text { dis- } \\
\text { solved } \\
\text { (mg/L } \\
\text { as } \mathrm{N} \text { ) }\end{array}$ & $\begin{array}{l}\text { Phos- } \\
\text { phorus, } \\
\text { ortho, } \\
\text { dis- } \\
\text { solved } \\
\text { (mg/L } \\
\text { as P) }\end{array}$ & $\begin{array}{c}\text { Carbon, } \\
\text { organic, } \\
\text { dis- } \\
\text { solved } \\
\text { (mg/L } \\
\text { as C) }\end{array}$ & $\begin{array}{c}\text { USGS } \\
\text { well } \\
\text { number }\end{array}$ \\
\hline 0.10 & 8.1 & $<10$ & 7 & 10 & 190 & -- & 143 & - & -- & -- & - & 1.7 & 3114-CH \\
\hline .10 & 18 & 2,600 & 220 & 16 & 66 & -- & 54 & - & - & - & -- & 1.5 & 3117 \\
\hline .10 & 11 & 850 & 190 & 33 & 38 & -- & 45 & - & -- & - & -- & .8 & 3122 \\
\hline .10 & 9.5 & $<10$ & 11 & 9 & 35 & - & 32 & -- & -- & - & -- & .8 & 3123 \\
\hline .10 & 8.0 & -- & 27,000 & 170 & 58 & -- & 84 & -- & - & - & -- & 2.4 & 3124 \\
\hline .50 & 6.8 & 50 & 72 & 46 & 110 & - & 143 & .. & - & -. & -- & 31 & 3125 \\
\hline .10 & 9.4 & $<10$ & $<3$ & 1 & 26 & -- & 14 & -- & - & -- & -- & .7 & 3126 \\
\hline .10 & 9.9 & 80 & 15 & 48 & 46 & - & 86 & -- & - & .- & -- & - & 3127 \\
\hline .20 & 5.8 & $<10$ & 7 & 140 & 140 & - & 40 & -- & - & - & -- & -- & 3128 \\
\hline$<.10$ & 8.4 & 130 & 110 & 5 & 17 & - & 16 & -- & -- & - & -- & 2.2 & 3131 \\
\hline .30 & 7.4 & 80 & 4 & 460 & 190 & -- & 143 & - & -- & -- & - & 2.3 & 3132 \\
\hline .10 & 9.5 & 350 & 170 & 32 & 18 & - & 20 & -- & - & - & -- & -- & 3133 \\
\hline .10 & 11 & 340 & 7 & 31 & 70 & -- & 99 & - & - & -- & - & 1.3 & 3135 \\
\hline .10 & 6.9 & 830 & 340 & 29 & 80 & - & 73 & - & -. & -- & - & 2.3 & 3136 \\
\hline .10 & 6.5 & $<10$ & 4 & 29 & 29 & $<10$ & 27 & $<0.010$ & $<0.010$ & 0.290 & 0.002 & .6 & 3160 \\
\hline .10 & 7.4 & 120 & 10 & 43 & 55 & -- & 27 & - & .- & -. & -- & - & 3166 \\
\hline .10 & 8.7 & 3,000 & 7 & 58 & 110 & -- & 72 & -- & -- & -- & -- & - & 3168 \\
\hline .10 & 7.9 & 80 & 11 & 7 & 67 & $<10$ & 27 & $<.010$ & $<.010$ & 1.70 & .004 & .4 & 3189 \\
\hline .10 & 8.4 & 410 & 20 & 79 & 130 & -- & 74 & -- & -- & -. & -- & - & 3213 \\
\hline .10 & 9.0 & 10 & 11 & 32 & 160 & - & 111 & -- & - & - & -- & -- & 3214 \\
\hline .10 & 7.3 & 46,000 & 88 & 34 & 200 & -- & 215 & -- & -- & -- & -- & -- & 3215 \\
\hline-- & 6.0 & -- & 1,900 & 72 & 53 & -- & -- & $<.010$ & $<.010$ & .230 & $<.001$ & 1.4 & 3219 \\
\hline .10 & 5.8 & 700 & 180 & 56 & 65 & $<10$ & 26 & .020 & $<.010$ & .270 & $<.001$ & 1.1 & \\
\hline .10 & 9.8 & 50 & 7 & 5 & 22 & -- & 20 & $<.010$ & $<.010$ & .110 & $<.001$ & 1.4 & 3301 \\
\hline .10 & 5.9 & 410 & 16 & 91 & 76 & $<10$ & 35 & $<.010$ & $<.010$ & .280 & $<.001$ & 1.0 & 3315 \\
\hline .10 & 7.8 & 40 & 24 & 270 & 220 & 10 & 78 & $<.010$ & $<.010$ & 6.00 & $<.001$ & 1.5 & 3325 \\
\hline .10 & 14 & 23,000 & 4 & 65 & 5 & $<10$ & 56 & .010 & $<.010$ & .720 & .009 & .6 & 3326 \\
\hline .20 & 6.1 & 40 & 10 & 120 & 140 & $<10$ & 35 & .020 & $<.010$ & .540 & $<.001$ & 1.5 & 3327 \\
\hline$<.10$ & 13 & 440,000 & 100 & 64 & 31 & $<10$ & 41 & $<.010$ & $<.010$ & 1.40 & $<.001$ & .9 & 3328 \\
\hline$<.10$ & 6.6 & 260 & 22 & 14 & 25 & $<10$ & 19 & $<.010$ & $<.010$ & $<.100$ & $<.001$ & .7 & 3329 \\
\hline
\end{tabular}


Table 21. Physical properties and chemical analyses for major ions, selected minor ions, nutrients, and dissolved organic carbon in ground water in the Chickies Quartzite and adjacent geologic units. Geologic unit codes are explained at beginning of table 20--Continued

\begin{tabular}{|c|c|c|c|c|c|c|c|c|c|c|c|c|c|}
\hline $\begin{array}{l}\text { USGS } \\
\text { well } \\
\text { number }\end{array}$ & $\begin{array}{c}\text { Geo- } \\
\text { logic } \\
\text { unit }\end{array}$ & Date & $\begin{array}{c}\text { pH } \\
\text { (stand- } \\
\text { ard } \\
\text { units) }\end{array}$ & $\begin{array}{c}\text { Temper- } \\
\text { ature, } \\
\text { water } \\
\left({ }^{\circ} \mathrm{C}\right)\end{array}$ & $\begin{array}{l}\text { Spe- } \\
\text { cific } \\
\text { con- } \\
\text { duct- } \\
\text { ance } \\
(\mu \mathrm{S} / \mathrm{cm})\end{array}$ & $\begin{array}{l}\text { Oxygen, } \\
\text { dis- } \\
\text { solved } \\
(\mathrm{mg} / \mathrm{L})\end{array}$ & $\begin{array}{c}\text { Alka- } \\
\text { linity } \\
\text { field } \\
(\mathrm{mg} / \mathrm{L} \\
\left.\text { as } \mathrm{CaCO}_{3}\right)\end{array}$ & $\begin{array}{l}\text { Cal- } \\
\text { cium, } \\
\text { dis- } \\
\text { solved } \\
(\mathrm{mg} / \mathrm{L} \\
\text { as Ca) }\end{array}$ & $\begin{array}{c}\text { Magne- } \\
\text { sium, } \\
\text { dis } \\
\text { solved } \\
\text { (mg/L } \\
\text { as } \mathrm{Mg} \text { ) }\end{array}$ & $\begin{array}{c}\text { Sodium, } \\
\text { dis- } \\
\text { solved } \\
(\mathrm{mg} / \mathrm{L} \\
\text { as } \mathrm{Na})\end{array}$ & $\begin{array}{l}\text { Potas- } \\
\text { sium, } \\
\text { dis- } \\
\text { solved } \\
\text { (mg/L } \\
\text { as } \mathrm{K}) \\
\end{array}$ & $\begin{array}{l}\text { Chlo- } \\
\text { ride, } \\
\text { dis- } \\
\text { solved } \\
\text { (mg/L } \\
\text { as Cl) }\end{array}$ & $\begin{array}{c}\text { Sul- } \\
\text { fate, } \\
\text { dis- } \\
\text { solved } \\
(\mathrm{mg} / \mathrm{L} \\
\left.\text { as } \mathrm{SO}_{4}\right)\end{array}$ \\
\hline CH-3330 & 377CCKS & $08-23-88$ & 4.8 & 12.0 & 57 & 9.2 & -- & 0.58 & 1.9 & 3.2 & 2.0 & 8.0 & 1.3 \\
\hline 3331 & 377CCKS & $08-23-88$ & 4.4 & 14.0 & 245 & 7.4 & 0 & 15 & 3.2 & 14 & 4.0 & 22 & 27 \\
\hline 3332 & 377ANTM & $08-30-88$ & 5.7 & 12.0 & 150 & 9.0 & 12 & 11 & 4.5 & 5.7 & 3.0 & 9.9 & 5.8 \\
\hline 3333 & $377 \mathrm{CCKS}$ & $09-06-88$ & 4.9 & 12.5 & 75 & 6.0 & 4 & 1.1 & 2.9 & 2.8 & 3.9 & 4.8 & 15 \\
\hline 3334 & 377CCKS & $09-06-88$ & 5.1 & 12.0 & 49 & 10.1 & 3 & .82 & 2.3 & 1.9 & 1.1 & 3.1 & 11 \\
\hline \multirow[t]{12}{*}{3335} & 377CCKS & $09-06-88$ & 4.6 & 12.5 & 370 & 2.6 & 1 & 5.7 & 8.0 & 45 & 2.4 & 86 & 19 \\
\hline & $377 \mathrm{CCKS}$ & 01-31-89 & 4.6 & 11.5 & 370 & 1.4 & 1 & -- & -- & -- & -- & 92 & 17 \\
\hline & 377CCKS & $02-28-89$ & 4.6 & 11.0 & 403 & 2.8 & 1 & - & -- & -- & -- & 100 & 23 \\
\hline & $377 \mathrm{CCKS}$ & 03-30-89 & 4.9 & 11.0 & 409 & 3.4 & 4 & -- & -- & - & -- & 95 & 29 \\
\hline & $377 \mathrm{CCKS}$ & 05-01-89 & 4.7 & 11.5 & 475 & 3.3 & 2 & -- & - & - & - & 120 & 29 \\
\hline & $377 \mathrm{CCKS}$ & 05-31-89 & 4.9 & 12.0 & 408 & 6.0 & 3 & -- & - & - & - & 94 & 31 \\
\hline & 377CCKS & $06-28-89$ & 4.6 & 12.5 & 440 & 1.6 & 0 & - & -- & -- & - & 110 & 28 \\
\hline & $377 \mathrm{CCKS}$ & 07-31-89 & 4.7 & 12.0 & 477 & 2.6 & 2 & - & -- & -- & -- & 120 & 27 \\
\hline & 377CCKS & $08-29-89$ & 4.5 & 13.0 & 455 & 1.8 & 0 & -- & - & -- & -- & 110 & 24 \\
\hline & 377CCKS & $09-29-89$ & 4.6 & 12.0 & 422 & .9 & 2 & -- & - & - & - & 110 & 19 \\
\hline & $377 \mathrm{CCKS}$ & $10-30-89$ & 4.6 & 12.0 & 418 & 2.2 & 1 & - & - & - & -- & 110 & 20 \\
\hline & $377 \mathrm{CCKS}$ & $11-27-89$ & 4.5 & 11.5 & 408 & 2.3 & 0 & - & - & - & - & 100 & 18 \\
\hline 3336 & 377CCKS & $09-06-88$ & 5.9 & 11.5 & 105 & 6.4 & 36 & 9.3 & 3.8 & 5.7 & 1.3 & 5.4 & 3.0 \\
\hline 3337 & $377 \mathrm{CCKS}$ & $09-08-88$ & 5.7 & 12.0 & 29 & 10.4 & 8 & 1.6 & .61 & 1.8 & 1.2 & 2.2 & 1.6 \\
\hline 3338 & $377 \mathrm{CCKS}$ & $09-08-88$ & 4.5 & 12.0 & 160 & 6.6 & 0 & 3.7 & 5.8 & 9.3 & 2.2 & 13 & 31 \\
\hline 3339 & 377CCKS & $09-09-88$ & 5.3 & 11.5 & 110 & 8.1 & 8 & 3.3 & 3.3 & 9.5 & 2.0 & 17 & 5.7 \\
\hline SP33 & 377HRPR & $07-27-87$ & 5.4 & 20.0 & 102 & 8.0 & 9 & -- & - & -- & - & - & -- \\
\hline LN-1684 & $377 \mathrm{CCKS}$ & $11-21-86$ & 5.6 & 9.5 & 16 & 8.5 & 6 & .40 & .20 & .90 & .90 & 1.0 & 1.1 \\
\hline 1685 & 377CCKS & $12-03-86$ & 6.2 & 11.0 & 633 & 2.0 & 130 & 22 & 11 & 59 & 10 & 68 & 34 \\
\hline 1686 & 377CCKS & $12-03-86$ & 5.2 & 11.5 & 18 & 8.0 & 5 & .40 & .30 & 1.1 & 2.1 & 1.4 & 1.4 \\
\hline 1687 & 377CCKS & $12-04-86$ & 4.8 & 11.5 & 46 & 6.5 & 3 & .60 & .80 & 3.1 & 3.0 & 4.7 & 6.2 \\
\hline 1688 & $377 \mathrm{CCKS}$ & $12-04-86$ & 4.4 & 12.0 & 341 & 7.0 & 0 & 33 & 8.8 & 7.9 & 1.4 & 18 & 46 \\
\hline 1689 & 377CCKS & $12-08-86$ & 5.7 & 12.0 & 171 & 3.8 & 16 & 9.9 & 7.4 & 4.2 & 4.6 & 10 & 13 \\
\hline 1690 & 377CCKS & $12-08-86$ & 5.1 & 10.5 & 166 & 7.7 & 6 & 6.0 & 3.3 & 15 & 5.1 & 26 & 5.0 \\
\hline 1691 & 377CCKS & $12-12-86$ & 5.7 & 11.5 & 151 & $<.1$ & 44 & 7.5 & 6.5 & 4.1 & .90 & 9.3 & 8.5 \\
\hline
\end{tabular}


Table 21. Physical properties and chemical analyses for major ions, selected minor ions, nutrients, and dissolved orçanic carbon in ground water in the Chickies Quartzite and adjacent geologic units. Geologic unit codes are explained at $r$ aginning of table 20--Continued

\begin{tabular}{|c|c|c|c|c|c|c|c|c|c|c|c|c|c|}
\hline $\begin{array}{l}\text { Fluo- } \\
\text { ride, } \\
\text { dis- } \\
\text { solved } \\
\text { (mg/L } \\
\text { as F) }\end{array}$ & $\begin{array}{l}\text { Silica, } \\
\text { dis- } \\
\text { solved } \\
(\mathrm{mg} / \mathrm{L} \\
\left.\text { as } \mathrm{SiO}_{2}\right)\end{array}$ & $\begin{array}{l}\text { Iron, } \\
\text { total } \\
\text { recov- } \\
\text { erable } \\
\text { ( } \mu g / \mathrm{L} \\
\text { as } \mathrm{Fe})\end{array}$ & $\begin{array}{l}\text { Iron, } \\
\text { dis- } \\
\text { solved } \\
\text { (ug/L } \\
\text { as Fe) }\end{array}$ & $\begin{array}{l}\text { Manga- } \\
\text { nese, } \\
\text { dis- } \\
\text { solved } \\
\text { ( } \mu \mathrm{g} / \mathrm{L} \\
\text { as } \mathrm{Mn} \text { ) }\end{array}$ & $\begin{array}{l}\text { Barium, } \\
\text { dis- } \\
\text { solved } \\
\text { ( } \mu \mathrm{g} / \mathrm{L} \\
\text { as } \mathrm{Ba} \text { ) }\end{array}$ & $\begin{array}{l}\text { Boron, } \\
\text { dis- } \\
\text { solved } \\
\text { ( } \mu \mathrm{g} / \mathrm{L} \\
\text { as B) }\end{array}$ & $\begin{array}{l}\text { Solids, } \\
\text { residue } \\
\text { at } 180{ }^{\circ} \mathrm{C} \\
\text { dis- } \\
\text { solved } \\
(\mathrm{mg} / \mathrm{L})\end{array}$ & $\begin{array}{l}\text { Nitro- } \\
\text { gen, } \\
\text { ammonia, } \\
\text { dis- } \\
\text { solved } \\
\text { (mg/L } \\
\text { as N) }\end{array}$ & $\begin{array}{l}\text { Nitro- } \\
\text { gen, } \\
\text { nitrite, } \\
\text { dis- } \\
\text { solved } \\
\text { (mg/L } \\
\text { as } N \text { ) }\end{array}$ & $\begin{array}{c}\text { Nitro- } \\
\text { gen, } \\
\mathrm{NO}_{2}+\mathrm{NO}_{3} \\
\text { dis- } \\
\text { solved } \\
\text { (mg/L } \\
\text { as } \mathrm{N} \text { ) }\end{array}$ & $\begin{array}{l}\text { Phos- } \\
\text { phorus, } \\
\text { ortho, } \\
\text { dis- } \\
\text { solved } \\
\text { (mg/L } \\
\text { as P) }\end{array}$ & $\begin{array}{c}\text { Carbon. } \\
\text { organic } \\
\text { dis- } \\
\text { solved } \\
\text { (mg/L } \\
\text { as C) }\end{array}$ & $\begin{array}{c}\text { USGS } \\
\text { well } \\
\text { number }\end{array}$ \\
\hline 0.10 & 7.1 & 20 & 25 & 16 & 53 & $<10$ & 34 & $<0.010$ & $<0.010$ & 1.50 & $<0.001$ & 0.7 & $3330-\mathrm{CH}$ \\
\hline .20 & 5.4 & 80 & 61 & 79 & 76 & 290 & 133 & $<.010$ & $<.010$ & 9.90 & $<.001$ & 2.4 & 3331 \\
\hline .10 & 12 & 50 & 4 & 1 & 14 & $<10$ & 107 & $<.010$ & $<.010$ & 7.80 & .031 & .5 & 3332 \\
\hline .10 & 8.8 & 260 & 150 & 47 & 190 & $<10$ & 50 & .030 & $<.010$ & .810 & $<.001$ & 1.2 & 3333 \\
\hline$<.10$ & 8.0 & 390 & 250 & 22 & 54 & $<10$ & 32 & $<.010$ & $<.010$ & $<100$ & $<.001$ & 1.1 & 3334 \\
\hline .10 & 7.4 & 10 & 6 & 70 & 180 & 10 & 198 & .220 & $<.010$ & 2.60 & $<.001$ & 1.2 & 3335 \\
\hline- & - & -- & - & - & - & - & - & .250 & .010 & 2.40 & - & -. & \\
\hline- & - & - & - & - & - & -- & - & .390 & $<.010$ & 2.50 & -- & - & \\
\hline- & - & -- & - & - & -. & -- & - & .190 & $<.010$ & 2.70 & - & - & \\
\hline -- & -. & - & - & - & - & - & - & .130 & $<.010$ & 2.60 & - & .. & \\
\hline- & - & - & - & - & - & -- & - & .020 & $<.010$ & 1.90 & - & - & \\
\hline- & - & - & - & - & - & - & - & .080 & $<.010$ & 2.60 & - & - & \\
\hline- & - & - & - & - & - & - & -- & .100 & $<.010$ & 2.90 & - & -- & \\
\hline- & - & -- & - & -- & -. & - & -. & .200 & $<.010$ & 2.90 & - & - & \\
\hline- & -- & - & - & - & - & - & -- & .240 & $<.010$ & 2.80 & - & 1.2 & \\
\hline- & - & - & -- & .. & -- & - & - & .230 & $<.010$ & 3.00 & - & 1.1 & \\
\hline .. & .. & -. & -- & -. & .. & -- & - & .180 & $<.010$ & 2.80 & - & 1.2 & \\
\hline .10 & 21 & $<10$ & 6 & $<1$ & 22 & $<10$ & 78 & .010 & $<.010$ & .260 & .038 & .5 & 3336 \\
\hline$<10$ & 9.6 & $<10$ & 10 & 2 & 9 & $<10$ & 13 & .010 & $<.010$ & .110 & .032 & .5 & 3337 \\
\hline .20 & 7.8 & 12,000 & 29 & 160 & 170 & $<10$ & 78 & .010 & $<.010$ & 2.20 & $<.001$ & 2.1 & 3338 \\
\hline$<.10$ & 11 & 6,700 & 44 & 36 & 66 & 10 & 64 & $<.010$ & $<.010$ & 1.20 & $<.001$ & .7 & 3339 \\
\hline- & - & - & - & -. & - & - & - & - & - & - & - & - & SP33 \\
\hline$<.10$ & 8.0 & 10 & 22 & $<1$ & 380 & -- & 7 & - & - & - & -- & .8 & 1684-LN \\
\hline$<.10$ & 4.8 & 1,400 & 150 & 400 & 140 & - & 299 & $\cdot-$ & - & - & - & 8.1 . & 1685 \\
\hline$<.10$ & 11 & 240 & 10 & 5 & 39 & - & 12 & - & - & -- & -- & .6 & 1686 \\
\hline$<.10$ & 13 & 690 & 35 & 48 & 52 & - & 25 & - & - & - & - & .4 & 1687 \\
\hline .10 & 5.3 & 40 & 9 & 41 & 86 & - & 185 & - & - & -- & -- & 1.7 & 1688 \\
\hline$<.10$ & 8.6 & 8,300 & 9 & 220 & 60 & - & 89 & - & - & -- & - & .9 & 1689 \\
\hline$<.10$ & 8.8 & 230 & 98 & 130 & 160 & - & 94 & - & - & - & - & .8 & 1690 \\
\hline .10 & 17 & 8,600 & 850 & 340 & 23 & - & 59 & - & -- & - & - & .4 & 1691 \\
\hline
\end{tabular}


Table 21. Physical properties and chemical analyses for major ions, selected minor ions, nutrients, and dissolved organic carbon in ground water in the Chickies Quartzite and adjacent geologic units. Geologic unit codes are explained at beginning of table 20--Continued

\begin{tabular}{|c|c|c|c|c|c|c|c|c|c|c|c|c|c|}
\hline $\begin{array}{l}\text { USGS } \\
\text { well } \\
\text { number }\end{array}$ & $\begin{array}{l}\text { Geo- } \\
\text { logic } \\
\text { unit }\end{array}$ & Date & $\begin{array}{c}\mathrm{pH} \\
\text { (stand- } \\
\text { ard } \\
\text { units) }\end{array}$ & $\begin{array}{c}\text { Temper- } \\
\text { ature, } \\
\text { water } \\
\left({ }^{\circ} \mathrm{C}\right)\end{array}$ & $\begin{array}{l}\text { Spe- } \\
\text { cific } \\
\text { con- } \\
\text { duct- } \\
\text { ance } \\
(\mu \mathrm{S} / \mathrm{cm})\end{array}$ & $\begin{array}{c}\text { Oxygen, } \\
\text { dis- } \\
\text { solved } \\
\text { (mg/L) }\end{array}$ & $\begin{array}{c}\text { Alka- } \\
\text { linity } \\
\text { field } \\
(\mathrm{mg} / \mathrm{L} \\
\text { as } \mathrm{CaCO}_{3} \text { ) }\end{array}$ & $\begin{array}{c}\text { Cal- } \\
\text { cium, } \\
\text { dis- } \\
\text { solved } \\
\text { (mg/L } \\
\text { as } \mathrm{Ca})\end{array}$ & $\begin{array}{l}\text { Magne- } \\
\text { sium, } \\
\text { dis } \\
\text { solved } \\
\text { (mg/L } \\
\text { as } \mathrm{Mg} \text { ) }\end{array}$ & $\begin{array}{l}\text { Sodium, } \\
\text { dis- } \\
\text { solved } \\
\text { (mg/L } \\
\text { as } \mathrm{Na} \text { ) }\end{array}$ & $\begin{array}{c}\text { Potas- } \\
\text { sium, } \\
\text { dis- } \\
\text { solved } \\
\text { (mg/L } \\
\text { as } \mathrm{K} \text { ) }\end{array}$ & $\begin{array}{l}\text { Chlo- } \\
\text { ride, } \\
\text { dis- } \\
\text { solved } \\
\text { (mg/L } \\
\text { as } \mathrm{Cl} \text { ) }\end{array}$ & $\begin{array}{c}\begin{array}{c}\text { Sul- } \\
\text { fate, }\end{array} \\
\text { dis- } \\
\text { solved } \\
(\mathrm{mg} / \mathrm{L} \\
\left.\text { as } \mathrm{SO}_{4}\right)\end{array}$ \\
\hline
\end{tabular}

\begin{tabular}{|c|c|c|c|c|c|c|c|c|c|c|c|c|c|}
\hline LN-1692 & $377 \mathrm{CCKS}$ & $12-30-86$ & 5.8 & 10.0 & 118 & 9.2 & 50 & 6.2 & 4.0 & 5.0 & 2.3 & 10 & 1.7 \\
\hline 1693 & 377CCKS & $12-30-86$ & 5.6 & 11.5 & 60 & 5.5 & 42 & -- & -- & - & -- & 5.2 & 6.9 \\
\hline 1694 & $377 \mathrm{CCKS}$ & $12-30-86$ & 5.1 & 10.0 & 42 & 7.8 & 4 & .60 & 1.1 & .90 & 1.2 & 1.9 & 6.3 \\
\hline 1695 & 377CCKS & $12-30-86$ & 4.9 & 11.5 & 63 & 6.2 & 28 & 1.1 & 2.0 & 3.0 & 2.6 & 6.3 & 2.7 \\
\hline 1696 & 377CCKS & $07-08-87$ & 4.7 & 14.5 & 67 & 9.4 & $<1$ & .25 & 2.9 & 3.5 & 1.7 & 9.2 & 9.3 \\
\hline 1697 & 377CCKS & $07-13-87$ & 4.4 & 13.0 & 187 & 10.3 & 0 & 8.4 & 5.7 & 6.0 & 2.9 & 8.2 & $<.20$ \\
\hline 1698 & 377CCKS & $07-13-87$ & 4.4 & 13.5 & 214 & 10.4 & 0 & 13 & 7.7 & 2.5 & 3.6 & 8.6 & 33 \\
\hline 1699 & 377CCKS & $07-14-87$ & 5.3 & 11.5 & 12 & 10.2 & 6 & .50 & .33 & .70 & 1.7 & 1.2 & .30 \\
\hline 1700 & 377CCKS & $07-15-87$ & 5.4 & 12.0 & 12 & 11.4 & 7 & .50 & .24 & .80 & 1.8 & .90 & 1.0 \\
\hline 1701 & 377CCKS & $07-15-87$ & 5.9 & 15.0 & 54 & 10.5 & 9 & .86 & 1.4 & 1.4 & 2.1 & 1.5 & 7.2 \\
\hline 1713 & 377CCKS & $09-01-88$ & 5.1 & 12.5 & 49 & 8.8 & 5 & .69 & 1.0 & 4.8 & 1.1 & 8.8 & $<.20$ \\
\hline 1714 & $377 \mathrm{CCKS}$ & $08-25-88$ & 5.0 & 13.0 & 103 & 9.4 & 3 & 3.8 & 5.6 & 2.5 & 2.0 & 8.0 & 9.2 \\
\hline 1715 & $377 \mathrm{CCKS}$ & $08-27-88$ & 5.2 & 12.0 & 21 & 11.0 & 3 & .26 & .31 & 1.5 & 1.4 & 2.5 & $<.20$ \\
\hline 1716 & 377CCKS & $08-25-88$ & 5.1 & 12.0 & 30 & 9.8 & 5 & .27 & .52 & 2.0 & 2.3 & 2.7 & .40 \\
\hline 1717 & $377 \mathrm{CCKS}$ & $08-03-88$ & 4.8 & 13.0 & 320 & 6.2 & 4 & 9.5 & 12 & 23 & 5.7 & 42 & 12 \\
\hline 1718 & 37TANTM & $08-03-88$ & 5.3 & 12.5 & 250 & 10.0 & 10 & 24 & 8.2 & 4.2 & 4.0 & 36 & 25 \\
\hline 1719 & 377CCKS & $08-03-88$ & 4.9 & 14.0 & 71 & 8.5 & 1 & 1.6 & 2.6 & 4.7 & 2.7 & 7.3 & .80 \\
\hline 1720 & 377HRPR & $08-04-88$ & 5.2 & 12.5 & 120 & 4.5 & 10 & 8.2 & 5.9 & 5.8 & 2.0 & 11 & 1.8 \\
\hline 1721 & 377CCKS & $08-04-88$ & 5.0 & 12.0 & 215 & 8.6 & 4 & 11 & 6.9 & 11 & 5.8 & 18 & 32 \\
\hline 1722 & 377CCKS & 08-04-88 & 5.8 & 12.0 & 119 & 8.5 & 18 & 12 & 3.1 & 3.2 & 3.8 & 3.8 & 23 \\
\hline 1723 & 377CCKS & $08-04-88$ & 5.0 & 13.0 & 105 & 7.8 & 6 & 4.5 & 4.5 & 5.2 & 2.8 & 11 & 2.1 \\
\hline 1724 & 377CCKS & $08-05-88$ & 5.3 & 12.5 & 115 & 6.0 & 6 & 4.5 & 7.0 & 4.0 & 4.7 & 8.2 & .90 \\
\hline 1725 & 377CCKS & $08-05-88$ & 4.5 & 12.0 & 165 & $<.1$ & 0 & 10 & 6.8 & 3.0 & 2.2 & 5.6 & 19 \\
\hline 1726 & 377CCKS & $08-05-88$ & 4.7 & 12.0 & 54 & 2.0 & 2 & .92 & 2.4 & 1.9 & 2.5 & 4.8 & 5.3 \\
\hline 1727 & 377CCKS & $08-08-88$ & 5.4 & 12.0 & 49 & 6.8 & 6 & 1.1 & .87 & 3.1 & 1.5 & 5.8 & 1.2 \\
\hline 1728 & 377CCKS & $08-08-88$ & 5.7 & 13.5 & 80 & 1.2 & 16 & 2.4 & 3.8 & 2.6 & 2.9 & 3.1 & 8.0 \\
\hline 1730 & $367 \mathrm{CNSG}$ & $08-13-88$ & 7.8 & 15.0 & 420 & 6.0 & 148 & 45 & 26 & 4.5 & 1.3 & 12 & 19 \\
\hline 1731 & $377 \mathrm{CCKS}$ & $08-13-88$ & 5.7 & 13.5 & 190 & 7.8 & 19 & 1 & 7.6 & 4.7 & 5.4 & 11 & 12 \\
\hline 1732 & 377CCKS & $08-15-88$ & 4.4 & 12.0 & 110 & 10.3 & 0 & 2.2 & 2.8 & 7.1 & 2.6 & 12 & 15 \\
\hline 1733 & 377ANTM & $08-15-88$ & 5.4 & 12.5 & 46 & 7.3 & 6 & 1.7 & 1.6 & 2.8 & 1.7 & 3.9 & 3.5 \\
\hline
\end{tabular}


Table 21. Physical properties and chemical analyses for major ions, selected minor ions, nutrients, and dissolved or carbon in ground water in the Chickies Quartzite and adjacent geologic units. Geologic unit codes are explained at beginning of table 20--Continued

\begin{tabular}{|c|c|c|c|c|c|c|c|c|c|c|c|c|c|}
\hline $\begin{array}{l}\text { Fluo- } \\
\text { ride, } \\
\text { dis- } \\
\text { solved } \\
\text { (mg/L } \\
\text { as F) }\end{array}$ & $\begin{array}{c}\text { Silica, } \\
\text { dis- } \\
\text { solved } \\
(\mathrm{mg} / \mathrm{L} \\
\left.\text { as } \mathrm{SiO}_{2}\right)\end{array}$ & $\begin{array}{l}\text { Iron, } \\
\text { total } \\
\text { recov- } \\
\text { erable } \\
\text { ( } \mu \mathrm{g} / \mathrm{L} \\
\text { as Fe) }\end{array}$ & $\begin{array}{l}\text { Iron, } \\
\text { dis- } \\
\text { solved } \\
(\mu g / L \\
\text { as Fe) }\end{array}$ & $\begin{array}{l}\text { Manga- } \\
\text { nese, } \\
\text { dis- } \\
\text { solved } \\
\text { ( } \mu \mathrm{g} / \mathrm{L} \\
\text { as } \mathrm{Mn} \text { ) }\end{array}$ & $\begin{array}{c}\text { Barium, } \\
\text { dis- } \\
\text { solved } \\
\text { ( } \mu \mathrm{g} / \mathrm{L} \\
\text { as } \mathrm{Ba} \text { ) }\end{array}$ & 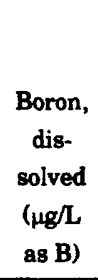 & $\begin{array}{c}\text { Solids, } \\
\text { residue } \\
\text { at } 180^{\circ} \mathrm{C} \\
\text { dis- } \\
\text { solved } \\
(\mathrm{mg} / \mathrm{L})\end{array}$ & $\begin{array}{l}\text { Nitro- } \\
\text { gen, } \\
\text { ammonia, } \\
\text { dis- } \\
\text { solved } \\
\text { (mg/L } \\
\text { as } N \text { ) }\end{array}$ & $\begin{array}{l}\text { Nitro- } \\
\text { gen, } \\
\text { nitrite, } \\
\text { dis- } \\
\text { solved } \\
\text { (mg/L } \\
\text { as N) }\end{array}$ & $\begin{array}{c}\text { Nitro- } \\
\text { gen, } \\
\mathrm{NO}_{2}+\mathrm{NO}_{3} \\
\text { dis- } \\
\text { solved } \\
\text { (mg/L } \\
\text { as } \mathrm{N} \text { ) }\end{array}$ & $\begin{array}{l}\text { Phos- } \\
\text { phorus, } \\
\text { ortho, } \\
\text { dis- } \\
\text { solved } \\
\text { (mg/L } \\
\text { as P) }\end{array}$ & $\begin{array}{c}\text { Carbor, } \\
\text { organic, } \\
\text { dis- } \\
\text { solved } \\
\text { (mg/L } \\
\text { as C) }\end{array}$ & $\begin{array}{c}\text { USGS } \\
\text { well } \\
\text { number }\end{array}$ \\
\hline$<0.10$ & 14 & 490 & $<10$ & $<10$ & $<100$ & - & 76 & -. & - & - & - & 1.0 & $1692-\mathrm{L} N$ \\
\hline$<.10$ & 12 & 50 & -- & -- & - & -- & 43 & - & - & - & - & .5 & 1693 \\
\hline$<.10$ & 5.9 & 180 & 250 & 30 & 100 & - & 23 & - & - & - & - & .7 & 1694 \\
\hline$<.10$ & 7.5 & 1,200 & $<10$ & 40 & 200 & - & 40 & - & - & - & - & 1.3 & 1695 \\
\hline .30 & 7.3 & 120 & 81 & 32 & 73 & - & 49 & - & - & -- & - & 2.0 & 1696 \\
\hline .10 & 6.4 & 560 & 36 & 100 & 91 & - & 112 & - & - & - & -- & 2.6 & 1697 \\
\hline .10 & 7.4 & 60 & 33 & 170 & 190 & - & 100 & - & - & -- & - & 2.2 & 1698 \\
\hline .10 & 8.3 & $<10$ & $<3$ & 2 & 19 & - & 12 & - & - & .- & - & .6 & 1699 \\
\hline .10 & 8.8 & 330 & 1,100 & 29 & 32 & -. & 12 & - & - & -- & - & .7 & 1700 \\
\hline .10 & 10 & 10,000 & 5,300 & 360 & 21 & - & 36 & - & - & - & - & .9 & 1701 \\
\hline$<.10$ & 8.3 & 2,500 & 440 & 22 & 39 & $<10$ & 33 & $<0.010$ & $<0.010$ & 0.580 & $<0.001$ & .5 & 1713 \\
\hline .10 & 8.0 & 640 & 5 & 26 & 160 & $<10$ & 63 & .020 & $<.010$ & 4.20 & $<.001$ & .8 & 1714 \\
\hline$<.10$ & 8.6 & 20 & 48 & 7 & 30 & $<10$ & 31 & .020 & $<.010$ & .170 & .001 & .5 & 1715 \\
\hline .10 & 8.2 & 220 & 80 & 39 & 63 & $<10$ & 23 & .030 & $<.010$ & .740 & .001 & .6 & 1716 \\
\hline .10 & 7.9 & 13,000 & 100 & 280 & 370 & 50 & 194 & 1.40 & .010 & 16.0 & $<.001$ & 2.5 & 1717 \\
\hline .10 & 6.3 & 40 & 9 & 29 & 35 & 40 & 161 & $<.010$ & $<.010$ & 5.10 & .030 & 1.9 & 1718 \\
\hline .10 & 7.7 & 550 & 27 & 60 & 98 & 20 & 56 & $<.010$ & $<.010$ & 4.60 & $<.001$ & 1.4 & 1719 \\
\hline .10 & 8.0 & 520 & 4 & 43 & 43 & 30 & 88 & $<.010$ & $<.010$ & 9.20 & .013 & 1.8 & 1720 \\
\hline .10 & 5.4 & 670 & 320 & 120 & 57 & 60 & 134 & .030 & $<.010$ & 7.40 & $<.001$ & 2.8 & 1721 \\
\hline .10 & 11 & 50 & 6 & 25 & 7 & $<10$ & 88 & $<.010$ & $<.010$ & 1.90 & $<.001$ & 1.7 & 1722 \\
\hline .10 & 8.9 & 30 & 5 & 32 & 89 & $<10$ & 71 & .050 & $<.010$ & 5.90 & .007 & 1.6 & 1723 \\
\hline .10 & 11 & 380 & 200 & 68 & 380 & $<10$ & 88 & .040 & $<.010$ & 9.80 & $<.001$ & 2.1 & 1724 \\
\hline .20 & 6.8 & 70 & 7 & 26 & 130 & $<10$ & 89 & $<.010$ & $<.010$ & 11.0 & $<.001$ & 2.0 & 1725 \\
\hline .10 & 8.0 & 80 & 6 & 67 & 120 & $<10$ & 33 & $<.010$ & $<.010$ & 1.60 & .004 & 2.2 & 1726 \\
\hline$<.10$ & 7.5 & 11,000 & $\grave{2}, 200$ & 82 & 65 & $<10$ & 26 & .080 & .010 & .830 & $<.001$ & .7 & 1727 \\
\hline .10 & 14 & 14,000 & 1,200 & 480 & 52 & $<10$ & 49 & .060 & .020 & 1.10 & $<.001$ & .4 & 1728 \\
\hline .10 & 12 & 5,800 & 30 & 1 & 6 & $<10$ & 233 & $<.010$ & $<.010$ & 6.80 & .020 & .5 & 1730 \\
\hline .10 & 12 & 6,900 & 17 & 23 & 37 & $<10$ & 123 & .010 & $<.010$ & 7.40 & $<.001$ & .7 & 1731 \\
\hline .10 & 6.7 & 160 & 11 & 75 & 190 & $<10$ & 60 & $<.010$ & $<.010$ & 1.50 & $<.001$ & 1.3 & 1732 \\
\hline .10 & 11 & $<10$ & 5 & 5 & 18 & $<10$ & 29 & $<.010$ & $<.010$ & .700 & $<.001$ & .8 & 1733 \\
\hline
\end{tabular}


Table 21. Physical properties and chemical analyses for major ions, selected minor ions, nutrients, and dissolved ornanic carbon in ground water in the Chickies Quartzite and adjacent geologic units. Geologic unit codes are explained at I ?ainning of table 20--Continued

\begin{tabular}{|c|c|c|c|c|c|c|c|c|c|c|c|c|c|}
\hline $\begin{array}{l}\text { USGS } \\
\text { well } \\
\text { number }\end{array}$ & $\begin{array}{l}\text { Geo- } \\
\text { logic } \\
\text { unit }\end{array}$ & Date & $\begin{array}{c}\mathrm{pH} \\
\text { (stand- } \\
\text { ard } \\
\text { units) }\end{array}$ & $\begin{array}{c}\text { Temper- } \\
\text { ature, } \\
\text { water } \\
\left({ }^{\circ} \mathrm{C}\right)\end{array}$ & $\begin{array}{l}\text { Spe- } \\
\text { cific } \\
\text { con- } \\
\text { duct- } \\
\text { ance } \\
(\mu \mathrm{S} / \mathrm{cm})\end{array}$ & $\begin{array}{l}\text { Oxygen, } \\
\text { dis- } \\
\text { solved } \\
\text { (mg/L) }\end{array}$ & $\begin{array}{c}\text { Alka- } \\
\text { linity } \\
\text { field } \\
(\mathrm{mg} / \mathrm{L} \\
\left.\text { as } \mathrm{CaCO}_{3}\right)\end{array}$ & $\begin{array}{l}\text { Cal- } \\
\text { cium, } \\
\text { dis- } \\
\text { solved } \\
\text { (mg/L } \\
\text { as Ca) }\end{array}$ & $\begin{array}{l}\text { Magne- } \\
\text { sium, } \\
\text { dis } \\
\text { solved } \\
\text { ( } \mathrm{mg} / \mathrm{L} \\
\text { as } \mathrm{Mg} \text { ) }\end{array}$ & $\begin{array}{l}\text { Sodium, } \\
\text { dis- } \\
\text { solved } \\
(\mathrm{mg} / \mathrm{L} \\
\text { as } \mathrm{Na})\end{array}$ & $\begin{array}{l}\text { Potas- } \\
\text { sium, } \\
\text { dis- } \\
\text { solved } \\
(\mathrm{mg} / \mathrm{L} \\
\text { as } \mathrm{K})\end{array}$ & $\begin{array}{l}\text { Chla- } \\
\text { ride, } \\
\text { dis- } \\
\text { solved } \\
(\mathrm{mg} / \mathrm{L} \\
\text { as } \mathrm{Cl})\end{array}$ & $\begin{array}{c}\text { Sul- } \\
\text { fate, } \\
\text { dis- } \\
\text { solved } \\
(\mathrm{mg} / \mathrm{L} \\
\left.\text { as } \mathrm{SO}_{4}\right)\end{array}$ \\
\hline LN-1734 & 377CCKS & $08-25-88$ & 4.7 & 13.0 & 175 & 9.0 & 1 & 4.0 & 8.3 & 8.9 & 4.4 & 20 & 1.7 \\
\hline 1735 & 377CCKS & $08-17-88$ & 4.8 & 12.0 & 68 & 11.0 & 1 & 1.3 & 1.2 & 6.6 & 1.4 & 11 & 5.5 \\
\hline 1736 & 377CCKS & $08-17-88$ & 5.1 & 12.0 & 45 & 11.0 & 2 & 1.2 & 1.9 & 1.7 & 1.3 & 2.7 & 8.3 \\
\hline 1737 & 377CCKS & $08-17-88$ & 5.5 & 12.0 & 43 & 9.2 & 8.0 & 1.0 & .80 & 2.7 & 1.8 & 3.6 & .50 \\
\hline 1738 & 377CCKS & $09-02-88$ & 4.8 & 11.5 & -- & - & 1 & 3.4 & 1.3 & 1.2 & .70 & 1.7 & 14 \\
\hline 1739 & 377CCKS & $09-01-88$ & 4.4 & 12.0 & 77 & 9.5 & 0 & 2.3 & 1.5 & 1.9 & .90 & 3.5 & 20 \\
\hline 1740 & 377CCKS & $09-02-88$ & 5.3 & 12.0 & 17 & 4.0 & 4 & .23 & .36 & 1.2 & .80 & 1.8 & .60 \\
\hline 1741 & 377CCKS & $09-02-88$ & 5.3 & 12.0 & 17 & 9.0 & 2 & .43 & .35 & 1.3 & .80 & 1.8 & $<.20$ \\
\hline 1742 & O00GBBR & $09-02-88$ & 6.2 & 12.0 & 55 & 9.0 & 21 & 4.9 & 2.0 & 3.0 & 1.2 & 1.9 & 1.4 \\
\hline MG- 399 & 377CCKS & $07-01-87$ & 6.3 & 12.0 & 329 & 7.7 & 54 & 22 & 13 & 14 & 3.4 & 45 & 16 \\
\hline 1000 & 377CCKS & $12-19-86$ & 6.3 & 11.5 & 186 & 7.0 & 40 & 11 & 10 & 7.2 & 1.4 & 23 & 3.8 \\
\hline 1001 & 377CCKS & $12-29-86$ & 6.3 & 11.5 & 204 & 4.0 & 52 & 18 & 7.0 & 4.1 & 2.2 & 14 & 19 \\
\hline 1002 & 377LDGR & $01-18-87$ & 7.5 & 11.0 & 351 & 5.0 & 192 & 37 & 25 & 3.5 & .70 & 4.5 & 11 \\
\hline 1003 & 377LDGR & $01-09-87$ & 7.3 & 12.0 & 626 & 1.6 & 296 & 59 & 38 & 19 & 5.6 & 34 & 20 \\
\hline 1004 & 337CCKS & $01-13-87$ & 5.9 & 11.5 & 335 & 6.6 & 40 & 23 & 9.6 & 16 & 6.2 & 36 & 45 \\
\hline YO- 88 & 377CCKS & $07-21-87$ & 5.9 & 14.0 & 39 & 9.4 & 17 & 3.0 & 1.6 & 1.8 & 1.0 & 2.3 & .50 \\
\hline 351 & 377CCKS & $08-10-88$ & 5.0 & 13.0 & 85 & 5.4 & 5 & 1.5 & 2.3 & 8.5 & 1.3 & 8.1 & .80 \\
\hline 371 & 377CCKS & $12-23-86$ & 5.2 & 12.0 & 78 & 7.6 & 4 & 3.0 & 4.0 & 4.2 & 1.2 & 4.9 & .70 \\
\hline 650 & 377CCKS & $08-11-88$ & 5.0 & 13.0 & 115 & 8.0 & 4 & 3.4 & 5.4 & 5.1 & 1.2 & 7.3 & .60 \\
\hline 792 & 377CCKS & $12-22-86$ & 5.5 & 11.0 & 31 & 5.6 & 10 & 5.7 & .60 & 1.0 & 1.4 & 1.6 & 1.2 \\
\hline \multirow[t]{2}{*}{1148} & 377CCKS & $12-09-86$ & 5.0 & 9.0 & 48 & 4.6 & 3 & 1.3 & 1.4 & 4.2 & 1.6 & 7.0 & 1.0 \\
\hline & $377 \mathrm{CCKS}$ & $07-22-87$ & 5.1 & 13.0 & 35 & 9.4 & 5 & .83 & .78 & 2.6 & 1.5 & 5.1 & .50 \\
\hline 1149 & 377CCKS & $12-09-86$ & 6.1 & 11.5 & 116 & 4.4 & 41 & 6.0 & 5.1 & 4.6 & 3.1 & 9.2 & 5.8 \\
\hline 1150 & $377 \mathrm{CCKS}$ & $12-09-86$ & 6.2 & 11.5 & 63 & 6.1 & 22 & 4.1 & 3.5 & 1.5 & .50 & 1.8 & 4.3 \\
\hline 1151 & $377 \mathrm{CCKS}$ & $12-10-86$ & 6.7 & 13.0 & 264 & 1.5 & 114 & 26 & 14 & 7.8 & .80 & 17 & 8.0 \\
\hline 1152 & 377CCKS & $12-10-86$ & 6.4 & 12.0 & 91 & 4.5 & 37 & 5.2 & 6.3 & 3.3 & .50 & 1.7 & 13 \\
\hline 1153 & 377CCKS & $12-10-86$ & 6.5 & 12.0 & 174 & $<.1$ & 110 & 17 & 6.0 & 4.6 & 1.5 & 7.0 & 12 \\
\hline 1154 & 377CCKS & $12-11-86$ & 5.4 & 11.5 & 85 & 7.0 & -- & 2.8 & 3.1 & 6.8 & 1.0 & 9.4 & 1.6 \\
\hline 1155 & $377 \mathrm{CCKS}$ & $12-11-86$ & 6.1 & 10.5 & 52 & 4.1 & 30 & 2.0 & 2.0 & 6.1 & .90 & .30 & 3.6 \\
\hline 1156 & 377CCKS & $12-11-86$ & 5.5 & 10.5 & 47 & 7.1 & 12 & 2.8 & 1.0 & 2.9 & 1.4 & 3.2 & 1.0 \\
\hline
\end{tabular}


Table 21. Physical properties and chemical analyses for major ions, selected minor ions, nutrients, and dissolved organic carbon in ground water in the Chickies Quartzite and adjacent geologic units. Geologic unit codes are explained at beginning of table 20--Continued

\begin{tabular}{|c|c|c|c|c|c|c|c|c|c|c|c|c|c|}
\hline $\begin{array}{l}\text { Fluo- } \\
\text { ride, } \\
\text { dis- } \\
\text { solved } \\
\text { (mg/L } \\
\text { as F) }\end{array}$ & $\begin{array}{l}\text { Silica, } \\
\text { dis- } \\
\text { solved } \\
\text { (mg/L } \\
\text { as } \mathrm{SiO}_{2} \text { ) }\end{array}$ & $\begin{array}{l}\text { Iron, } \\
\text { total } \\
\text { recov- } \\
\text { erable } \\
\mu g / L \\
\text { as } \mathrm{Fe} \text { ) }\end{array}$ & $\begin{array}{c}\text { Iron, } \\
\text { dis- } \\
\text { solved } \\
(\mu \mathrm{g} / \mathrm{L} \\
\text { as } \mathrm{Fe})\end{array}$ & $\begin{array}{l}\text { Manga- } \\
\text { nese, } \\
\text { dis- } \\
\text { solved } \\
\text { ( } \mu \mathrm{g} / \mathrm{L} \\
\text { as } \mathrm{Mn} \text { ) }\end{array}$ & $\begin{array}{l}\text { Barium, } \\
\text { dis- } \\
\text { solved } \\
(\mu \mathrm{g} / \mathrm{L} \\
\text { as } \mathrm{Ba})\end{array}$ & $\begin{array}{l}\text { Boron, } \\
\text { dis- } \\
\text { solved } \\
\text { ( } \mu \mathrm{g} / \mathrm{L} \\
\text { as B) }\end{array}$ & $\begin{array}{c}\text { Solids, } \\
\text { residue } \\
\text { at } 180{ }^{\circ} \mathrm{C} \\
\text { dis- } \\
\text { solved } \\
\text { (mg/L) }\end{array}$ & $\begin{array}{l}\text { Nitro- } \\
\text { gen, } \\
\text { ammonia, } \\
\text { dis- } \\
\text { solved } \\
\text { (mg/L } \\
\text { as } N \text { ) }\end{array}$ & $\begin{array}{l}\text { Nitro- } \\
\text { gen, } \\
\text { nitrite, } \\
\text { dis- } \\
\text { solved } \\
\text { (mg/L } \\
\text { as N) }\end{array}$ & $\begin{array}{c}\text { Nitro- } \\
\text { gen, } \\
\mathrm{NO}_{2}+\mathrm{NO}_{3} \\
\text { dis- } \\
\text { solved } \\
\text { (mg/L } \\
\text { as } \mathrm{N} \text { ) }\end{array}$ & $\begin{array}{l}\text { Phos- } \\
\text { phorus, } \\
\text { ortho, } \\
\text { dis- } \\
\text { solved } \\
\text { (mg/L } \\
\text { as } P \text { ) }\end{array}$ & $\begin{array}{c}\text { Carbor. } \\
\text { organis, } \\
\text { dis- } \\
\text { solved } \\
\text { (mg/L } \\
\text { as C) }\end{array}$ & $\begin{array}{c}\text { USGS } \\
\text { well } \\
\text { number }\end{array}$ \\
\hline 0.10 & 9.0 & $<10$ & 9 & 130 & 210 & $<10$ & 115 & 0.020 & $<0.010$ & 8.90 & 0.004 & 0.7 & 1734-LN \\
\hline .10 & 6.7 & 20 & 3 & 29 & 74 & $<10$ & 35 & -- & - & -- & $<.001$ & .8 & 1735 \\
\hline$<.10$ & 7.6 & 90 & 54 & 13 & 58 & $<10$ & 18 & $<.010$ & $<.010$ & .520 & $<.001$ & .9 & 1736 \\
\hline .10 & 8.7 & 4,200 & 1,800 & 44 & 56 & $<10$ & 31 & .050 & $<.010$ & 1.10 & $<.001$ & .7 & 1737 \\
\hline .10 & 5.5 & 10 & 10 & 150 & 210 & $<10$ & 39 & $<.010$ & $<.010$ & .190 & $<.001$ & 1.2 & 1738 \\
\hline .10 & 5.9 & 40 & 7 & 320 & 220 & $<10$ & 41 & $<.010$ & $<.010$ & .410 & $<.001$ & 1.5 & 1739 \\
\hline$<.10$ & 7.2 & 9,300 & 330 & 9 & 13 & $<10$ & 23 & $<.010$ & $<.010$ & .100 & $<.001$ & .4 & 1740 \\
\hline$<.10$ & 7.2 & $<10$ & 15 & 3 & 9 & $<10$ & 19 & $<.010$ & $<.010$ & $<.100$ & $<.001$ & .5 & 1741 \\
\hline$<.10$ & 22 & 210 & 6 & 3 & 8 & $<10$ & 36 & $<.010$ & $<.010$ & .210 & .024 & .4 & 1742 \\
\hline .10 & 11 & 30 & 18 & 2 & 10 & - & 179 & - & - & - & -. & .8 & 399-MG \\
\hline .10 & 23 & 970 & 7 & 10 & 39 & - & 103 & -- & - & -- & - & .5 & 1000 \\
\hline$<.10$ & 8.3 & 4,900 & 2,000 & 20 & 100 & - & 112 & .- & -- & -- & -- & 1.4 & 1001 \\
\hline$<.10$ & 9.7 & 13,000 & 12 & 39 & 20 & -- & 195 & -. & - & -- & - & .8 & 1002 \\
\hline$<.10$ & 11 & 219 & 19 & 350 & 150 & - & 343 & - & -. & .- & .- & .8 & 1003 \\
\hline$<.10$ & 8.8 & 50 & 12 & 59 & 63 & -- & 172 & -- & -. & .. & - & 1.0 & 1004 \\
\hline .10 & 14 & 1,800 & 290 & 12 & 7 &.- & 26 & - & .. & .. & - & .7 & 88-YO \\
\hline$<.10$ & 11 & $<10$ & 5 & 10 & 38 & 20 & 56 & $<.010$ & $<.010$ & 4.30 & .052 & .9 & 351 \\
\hline$<.10$ & 11 & 10 & $<10$ & $<10$ & 100 & - & 52 & .- & -. & -- & - & .4 & 371 \\
\hline$<.10$ & 7.7 & 10 & 5 & 21 & 30 & $<10$ & 72 & $<.010$ & $<.010$ & 8.10 & .002 & .6 & 650 \\
\hline$<.10$ & 8.0 & 2,600 & 130 & 20 & $<100$ & - & 15 & - & -- & -- & - & .3 & 792 \\
\hline$<.10$ & 7.1 & 1,000 & 40 & 14 & 30 & -. & 25 & - & -- & - & -- & .7 & 1148 \\
\hline .10 & 6.5 & 8,700 & 13 & 6 & 15 & - & 24 & -- & -- & -- & - & .8 & \\
\hline .20 & 21 & 4,300 & 5,800 & 870 & 50 & - & 63 & - & .. & - & - & -- & 1149 \\
\hline$<.10$ & 7.9 & 160 & 140 & 47 & 11 & -- & 51 & -- & -. & -- & - & .3 & 1150 \\
\hline .10 & 21 & 1,200 & 220 & 230 & 15 & - & 143 & - & .- & -. & -. & .5 & 1151 \\
\hline .20 & 20 & 3,300 & 2,400 & 700 & 4 & - & 51 & - & -- & -- & - & .3 & 1152 \\
\hline .20 & 28 & 9,700 & 9,500 & 610 & 86 & -. & 92 & - & -- & -- & -- & .3 & 1153 \\
\hline$<.10$ & 9.1 & 10 & 9 & 42 & 15 & - & 43 & -- & -- & - & - & .3 & 1154 \\
\hline .10 & 28 & $<10$ & 7 & $<10$ & $<2$ & -- & 39 & .- & .. & -- & - & .5 & 1155 \\
\hline$<.10$ & 14 & 10 & 4 & 1 & 25 & .- & 33 & -- & .- & - & -. & .6 & 1156 \\
\hline
\end{tabular}


Table 21. Physical properties and chemical analyses for major ions, selected minor ions, nutrients, and dissolved organic carbon in ground water in the Chickies Quartzite and adjacent geologic units. Geologic unit codes are explained at b?ginning of table 20--Continued

\begin{tabular}{|c|c|c|c|c|c|c|c|c|c|c|c|c|c|}
\hline $\begin{array}{l}\text { USGS } \\
\text { well } \\
\text { number }\end{array}$ & $\begin{array}{l}\text { Geo- } \\
\text { logic } \\
\text { unit }\end{array}$ & Date & $\begin{array}{c}\text { pH } \\
\text { (stand- } \\
\text { ard } \\
\text { units) }\end{array}$ & $\begin{array}{c}\text { Temper- } \\
\text { ature, } \\
\text { water } \\
\left({ }^{\circ} \mathrm{C}\right)\end{array}$ & $\begin{array}{l}\text { Spe- } \\
\text { cific } \\
\text { con- } \\
\text { duct- } \\
\text { ance } \\
(\mu \mathrm{S} / \mathrm{cm})\end{array}$ & $\begin{array}{l}\text { Oxygen, } \\
\text { dis- } \\
\text { solved } \\
\text { (mg/L) }\end{array}$ & $\begin{array}{c}\text { Alka- } \\
\text { linity } \\
\text { field } \\
(\mathrm{mg} / \mathrm{L} \\
\left.\text { as } \mathrm{CaCO}_{3}\right)\end{array}$ & $\begin{array}{l}\text { Cal- } \\
\text { cium, } \\
\text { dis- } \\
\text { solved } \\
\text { (mg/L } \\
\text { as Ca) }\end{array}$ & $\begin{array}{l}\text { Magne- } \\
\text { sium, } \\
\text { dis } \\
\text { solved } \\
\text { (mg/L } \\
\text { as } \mathrm{Mg} \text { ) }\end{array}$ & $\begin{array}{c}\text { Sodium, } \\
\text { dis- } \\
\text { solved } \\
(\mathrm{mg} / \mathrm{L} \\
\text { as } \mathrm{Na} \text { ) }\end{array}$ & $\begin{array}{l}\text { Potas- } \\
\text { sium, } \\
\text { dis- } \\
\text { solved } \\
\text { (mg/L } \\
\text { as K) }\end{array}$ & $\begin{array}{l}\text { Chlo- } \\
\text { ride, } \\
\text { dis- } \\
\text { solved } \\
\text { (mg/L } \\
\text { as } \mathrm{Cl} \text { ) }\end{array}$ & $\begin{array}{c}\text { Sul- } \\
\text { fate, } \\
\text { dis- } \\
\text { solved } \\
\text { (mg/L } \\
\left.\text { as } \mathrm{SO}_{4}\right)\end{array}$ \\
\hline YO-1157 & $377 \mathrm{CCKS}$ & $12-22-86$ & 4.7 & 12.0 & 136 & 3.6 & 6 & 4.4 & 3.8 & 11 & 1.8 & 13 & 9.7 \\
\hline 1158 & 377CCKS & $12-23-86$ & 4.9 & 12.0 & 173 & 4.0 & 2 & 3.7 & 4.7 & 18 & 2.6 & 17 & 1.3 \\
\hline 1159 & 377CCKS & $12-23-86$ & 6.4 & 11.0 & 238 & 4.3 & 48 & 19 & 9.0 & 8.5 & .70 & 12 & 10 \\
\hline 1160 & 377HRPR & $12-23-86$ & 6.2 & 10.5 & 168 & 8.3 & 16 & 9.0 & 6.7 & 2.3 & 1.1 & 2.7 & 27 \\
\hline 1161 & $377 \mathrm{CCKS}$ & $12-24-86$ & 6.9 & 11.0 & 15 & $<.1$ & 90 & 17 & 11 & 1.0 & .30 & 2.8 & 11 \\
\hline 1162 & 377HRPR & $07-21-87$ & 5.3 & 13.0 & 80 & - & 8 & 4.6 & 2.6 & 6.2 & 1.7 & 7.1 & .50 \\
\hline 1163 & $377 \mathrm{CCKS}$ & $07-21-87$ & 5.3 & 13.0 & 26 & 9.0 & 7 & .54 & .35 & 1.8 & 1.4 & 1.7 & 3.0 \\
\hline 1164 & $377 \mathrm{CCKS}$ & $07-22-87$ & 5.8 & 14.0 & 65 & 7.1 & 20 & 5.0 & 3.3 & 2.2 & .90 & 4.2 & 1.1 \\
\hline 1165 & 377CCKS & $07-22-87$ & 4.9 & 15.0 & 145 & 6.0 & 4 & 8.2 & 4.8 & 8.2 & 1.7 & 12 & 24 \\
\hline 1166 & $377 \mathrm{CCKS}$ & $07-23-87$ & 4.4 & 14.0 & 200 & 5.9 & 0 & 9.2 & 4.4 & 17 & 5.1 & 34 & 2.9 \\
\hline 1167 & 377HRPR & $07-23-87$ & 5.6 & 13.5 & 128 & 7.0 & 16 & 8.4 & 4.2 & 5.6 & 3.7 & 8.3 & 6.4 \\
\hline 1168 & 377VNTG & $07-23-87$ & 7.3 & 13.5 & 250 & 6.2 & 116 & 30 & 14 & 3.0 & 1.7 & 3.5 & 5.7 \\
\hline 1172 & 377CCKS & $08-11-88$ & 5.2 & 13.0 & 30 & 9.0 & 6 & 1.3 & .62 & 1.7 & 1.4 & 3.9 & .50 \\
\hline 1175 & $377 \mathrm{CCKS}$ & $08-08-88$ & 5.6 & 12.0 & 24 & 6.2 & 10 & .66 & .38 & 1.0 & 1.3 & 1.6 & 1.4 \\
\hline 1176 & $377 \mathrm{CCKS}$ & $08-09-88$ & 5.3 & 14.5 & 89 & 10.2 & 5 & 4.2 & 2.7 & 4.4 & 2.1 & 7.5 & 11 \\
\hline 1177 & 377CCKS & $08-09-88$ & 5.9 & 12.5 & 41 & 8.8 & 16 & 3.5 & 1.4 & 2.0 & .80 & 1.3 & 1.7 \\
\hline 1178 & $377 \mathrm{CCKS}$ & $08-09-88$ & 5.2 & 15.5 & 34 & 10.2 & 6 & 1.6 & .83 & 1.5 & 2.1 & 3.6 & .90 \\
\hline 1179 & 377CCKS & $08-09-88$ & 4.7 & 12.5 & 122 & -- & 2 & 3.4 & 2.3 & 11 & 2.8 & 22 & 8.6 \\
\hline 1180 & 377CCKS & $08-10-88$ & 5.5 & 12.0 & 38 & 12.0 & 6 & 1.3 & 1.9 & 1.0 & 1.0 & 2.1 & 4.2 \\
\hline 1181 & 377CCKS & $08-10-88$ & 5.6 & 14.0 & 58 & 6.0 & 11 & 3.7 & 2.0 & 2.6 & 1.1 & 3.1 & 3.8 \\
\hline 1182 & 377CCKS & $08-10-88$ & 5.3 & 13.5 & 45 & 8.5 & 4 & 1.9 & 1.6 & 2.7 & .90 & 2.7 & 2.7 \\
\hline 1183 & $377 \mathrm{CCKS}$ & $08-11-88$ & 5.7 & -- & 180 & 6.4 & 1 & 3.5 & 5.9 & 18 & 1.1 & 25 & 1.5 \\
\hline 1184 & 377CCKS & $09-07-88$ & 4.6 & 14.0 & 93 & 7.0 & 1 & 2.7 & 2.3 & 4.4 & 2.9 & 6.6 & 14 \\
\hline 1185 & $377 \mathrm{CCKS}$ & $09-07-88$ & 4.9 & 13.0 & 50 & 9.2 & 2 & 2.3 & 1.5 & 1.4 & 1.0 & 4.6 & 8.4 \\
\hline 1186 & $377 \mathrm{CCKS}$ & $09-07-88$ & 4.9 & 12.5 & 50 & 0.2 & 3 & 1.4 & 1.1 & 3.8 & 1.0 & 7.7 & .40 \\
\hline
\end{tabular}


Table 21. Physical properties and chemical analyses for major ions, selected minor ions, nutrients, and dissolved orçanic carbon in ground water in the Chickies Quartzite and adjacent geologic units. Geologic unit codes are explained at r?ginning of table 20--Continued

\begin{tabular}{|c|c|c|c|c|c|c|c|c|c|c|c|c|c|}
\hline $\begin{array}{l}\text { Fluo- } \\
\text { ride, } \\
\text { dis- } \\
\text { solved } \\
\text { (mg/L } \\
\text { as F) }\end{array}$ & $\begin{array}{l}\text { Silica, } \\
\text { dis- } \\
\text { solved } \\
(\mathrm{mg} / \mathrm{L} \\
\left.\text { as } \mathrm{SiO}_{2}\right)\end{array}$ & $\begin{array}{c}\text { Iron, } \\
\text { total } \\
\text { recov- } \\
\text { erable } \\
\text { ( } \mu \mathrm{g} / \mathrm{L} \\
\text { as Fe) }\end{array}$ & $\begin{array}{l}\text { Iron, } \\
\text { dis- } \\
\text { solved } \\
(\mu \mathrm{g} / \mathrm{L} \\
\text { as } \mathrm{Fe})\end{array}$ & $\begin{array}{c}\text { Manga- } \\
\text { nese, } \\
\text { dis- } \\
\text { solved } \\
(\mu g / L \\
\text { as } \mathrm{Mn})\end{array}$ & $\begin{array}{c}\text { Barium, } \\
\text { dis- } \\
\text { solved } \\
(\mu \mathrm{g} / \mathrm{L} \\
\text { as } \mathrm{Ba})\end{array}$ & $\begin{array}{c}\text { Boron, } \\
\text { dis- } \\
\text { solved } \\
\text { ( } \mu \mathrm{g} / \mathrm{L} \\
\text { as B) }\end{array}$ & $\begin{array}{c}\text { Solids, } \\
\text { residue } \\
\text { at } 180^{\circ} \mathrm{C} \\
\text { dis- } \\
\text { solved } \\
(\mathrm{mg} / \mathrm{L})\end{array}$ & $\begin{array}{l}\text { Nitro- } \\
\text { gen, } \\
\text { ammonia, } \\
\text { dis- } \\
\text { solved } \\
\text { (mg/L } \\
\text { as } N \text { ) }\end{array}$ & $\begin{array}{l}\text { Nitro- } \\
\text { gen, } \\
\text { nitrite, } \\
\text { dis- } \\
\text { solved } \\
(\mathrm{mg} / \mathrm{L} \\
\text { as } \mathrm{N})\end{array}$ & $\begin{array}{c}\text { Nitro- } \\
\text { gen, } \\
\mathrm{NO}_{2}+\mathrm{NO}_{3} \\
\text { dis- } \\
\text { solved } \\
\text { (mg/L } \\
\text { as } \mathrm{N} \text { ) }\end{array}$ & $\begin{array}{l}\text { Phos- } \\
\text { phorus, } \\
\text { ortho, } \\
\text { dis- } \\
\text { solved } \\
\text { (mg/L } \\
\text { as P) }\end{array}$ & $\begin{array}{c}\text { Carbon, } \\
\text { organic, } \\
\text { dis- } \\
\text { solved } \\
(\mathrm{mg} / \mathrm{L} \\
\text { as C) }\end{array}$ & $\begin{array}{c}\text { USGS } \\
\text { well } \\
\text { number }\end{array}$ \\
\hline$<0.10$ & 6.8 & 120 & 150 & 100 & 100 & -- & 79 & - & -- & -- & - & 1.0 & 1157-YO \\
\hline$<.10$ & 8.9 & 50 & 40 & 50 & 100 & - & 103 & -- & -- & -- & - & .6 & 1158 \\
\hline$<.10$ & 19 & 260 & 130 & 20 & 100 & -- & 140 & -. & -- & .. & -- & .5 & 1159 \\
\hline$<10$ & 8.4 & 70 & 20 & $<10$ & $<100$ & -. & 76 & -- & .- & -- & -- & .7 & 1160 \\
\hline .20 & 7.5 & 2,200 & 1,900 & 220 & 100 & -- & 101 & - & -- & -- & -- & .4 & 1161 \\
\hline .10 & 12 & 20 & 5 & 5 & 25 & -- & 65 & -- & -- & -- & -- & .6 & 1162 \\
\hline .10 & 6.9 & 590 & 180 & 46 & 8 & - & 18 & -- & - & - & - & .4 & 1163 \\
\hline .10 & 8.1 & 20 & $<3$ & 9 & 5 & - & 41 & -- & -- & -- & - & .5 & 1164 \\
\hline .10 & 7.5 & 40 & 22 & 70 & 47 & -- & 84 & - & -- & - & -- & 1.7 & 1165 \\
\hline .10 & 8.8 & 20 & 17 & 44 & 170 & -- & 122 & -- & -- & - & - & 1.0 & 1166 \\
\hline .10 & 18 & 240 & 21 & 9 & 5 & -- & 92 & - & -- & -. & - & .7 & 1167 \\
\hline .10 & 9.3 & 50 & $<3$ & $<1$ & 15 & -. & 153 & -- & .- & - & - & .5 & 1168 \\
\hline .10 & 7.2 & 60 & $<3$ & 2 & 6 & $<10$ & 24 & 0.010 & $<0.010$ & 0.280 & 0.017 & .7 & 1172 \\
\hline$<.10$ & 7.2 & 46,000 & 590 & 77 & 15 & $<10$ & 18 & .010 & $<.010$ & .140 & $<.001$ & 2.0 & 1175 \\
\hline$<.10$ & 8.4 & 1,000 & 11 & 10 & 66 & $<10$ & 49 & .020 & .010 & 2.70 & .002 & .8 & 1176 \\
\hline$<.10$ & 12 & 1,100 & 67 & 20 & 4 & $<10$ & 26 & $<.010$ & $<.010$ & $<.100$ & .001 & .5 & 1177 \\
\hline$<.10$ & 8.2 & 280 & 16 & 29 & 31 & $<10$ & 27 & .020 & $<.010$ & .780 & $<.001$ & .5 & 1178 \\
\hline$<.10$ & 7.5 & 40 & 12 & 27 & 150 & $<10$ & 66 & .010 & $<.010$ & .840 & $<.001$ & 1.2 & 1179 \\
\hline .10 & 6.5 & $<10$ & 4 & 6 & 9 & $<10$ & 26 & .020 & $<.010$ & .740 & .019 & .4 & 1180 \\
\hline .10 & 12 & 180 & 48 & 37 & 50 & $<10$ & 39 & .010 & $<.010$ & 1.20 & .024 & .6 & 1181 \\
\hline$<10$ & 9.8 & 110 & 49 & 23 & 35 & $<10$ & 28 & .010 & $<.010$ & 1.70 & .001 & .4 & 1182 \\
\hline .10 & 7.2 & 20 & 6 & 97 & 53 & $<10$ & 94 & .010 & $<.010$ & 6.70 & $<.001$ & .4 & 1183 \\
\hline$<.10$ & 7.4 & 160 & 5 & 57 & 120 & 20 & 44 & $<.010$ & $<.010$ & 1.80 & .012 & 1.3 & 1184 \\
\hline$<.10$ & 6.1 & 240 & 5 & 27 & 42 & $<10$ & 24 & $<.010$ & $<.010$ & .570 & $<.001$ & 1.0 & 1185 \\
\hline$<.10$ & 6.6 & 20 & 6 & 62 & 22 & $<10$ & 42 & $<.010$ & $<.010$ & .470 & .009 & .7 & 1186 \\
\hline
\end{tabular}


Table 22. Chemical analyses of radionuclides in ground water in the Chickies Quartzite and adjacent geologic units. Geologic unit codes are explained at the beginning of table 20. Counting or analytical error values for each sample give counting or analytical uncertainty at the $2 \sigma$ or 95 -percent-confidence level.

[pCi/L, picocuries per liter; $\mu \mathrm{g} / \mathrm{L}$, micrograms per liter; -- no data; $\sigma$, sigma; CE, counting error; AE, analytical error]

\begin{tabular}{|c|c|c|c|c|c|c|c|c|c|}
\hline $\begin{array}{l}\text { USGS } \\
\text { well } \\
\text { number }\end{array}$ & $\begin{array}{l}\text { Geo- } \\
\text { logic } \\
\text { unit }\end{array}$ & Date & $\begin{array}{c}\text { Radon- } \\
222, \\
\text { total } \\
(\mathrm{pCi} / \mathrm{L})\end{array}$ & $\begin{array}{l}\text { Radium- } \\
226, \\
\text { dis- } \\
\text { solved, } \\
\text { radon } \\
\text { method } \\
(\mathrm{pCi} / \mathrm{L})\end{array}$ & $\begin{array}{l}\text { Radium- } \\
\text { 226, } \\
2-\sigma \\
\mathrm{CE} \\
(\mathrm{pCi} / \mathrm{L})\end{array}$ & $\begin{array}{l}\text { Radium- } \\
228, \\
\text { dis- } \\
\text { solved } \\
\text { (pCi/L } \\
\text { as } \\
\mathrm{Ra-228})\end{array}$ & $\begin{array}{c}\text { Radium- } \\
228 \\
2-\sigma \\
\mathrm{CE} \\
(\mathrm{pCi} / \mathrm{L})\end{array}$ & $\begin{array}{l}\text { Uranium, } \\
\text { natural, } \\
\text { dis- } \\
\text { solved } \\
\text { ( } \mu \mathrm{g} / \mathrm{L} \\
\text { as U) }\end{array}$ & $\begin{array}{c}\text { Uranium, } \\
2-\sigma \\
\text { AE } \\
(\mu \mathrm{g} / \mathrm{L})\end{array}$ \\
\hline BE-1440 & $377 \mathrm{CCKS}$ & $12-22-86$ & 110 & 1.0 & 0.3 & 2.2 & 0.4 & 0.18 & 0.03 \\
\hline BK- 396 & 377CCKS & $12-21-86$ & 1,600 & .34 & .09 & $<.90$ & - & .22 & .03 \\
\hline 1200 & 377CCKS & $12-21-86$ & 900 & .42 & .12 & $<1.0$ & -- & .14 & .02 \\
\hline 1201 & $377 \mathrm{CCKS}$ & $12-31-86$ & 760 & .26 & .07 & $<.50$ & - & .34 & .05 \\
\hline 1202 & 377CCKS & $12-31-86$ & 2,600 & 3.8 & .5 & 50 & 2.0 & .33 & .05 \\
\hline & 377CCKS & $05-07-87$ & 2,800 & 5.7 & .6 & 66 & 2.0 & .39 & .06 \\
\hline 1227 & 400FLCGP & $06-22-87$ & 1,200 & 1.0 & .1 & 1.6 & .4 & $<.05$ & - \\
\hline 1228 & $377 \mathrm{CCKS}$ & $06-22-87$ & 3,500 & 2.9 & .3 & 5.4 & .5 & $<.05$ & - \\
\hline 1288 & 377HRDS & $09-03-88$ & 12,000 & 1.7 & .3 & 3.6 & 1.5 & .14 & .02 \\
\hline SP21 & 377CCKS & $05-27-87$ & -- & 3.8 & .4 & 8.1 & .8 & .40 & .06 \\
\hline CH- 293 & 377CCKS & $11-13-86$ & 3,000 & 1.6 & .5 & 3.5 & 1.9 & .30 & .05 \\
\hline 333 & $377 \mathrm{CCKS}$ & $11-15-86$ & 1,300 & 9.5 & 1.0 & 22 & 2.0 & .30 & .05 \\
\hline 417 & 377CCKS & $11-24-86$ & 4,300 & .48 & .12 & $<1.0$ & - & .17 & .03 \\
\hline 418 & $377 \mathrm{CCKS}$ & $12-05-86$ & 9,300 & 2.9 & .5 & 7.6 & 1.9 & .32 & .05 \\
\hline 427 & 377HRPR & $12-05-86$ & 270 & .78 & .48 & 1.8 & .8 & .16 & .02 \\
\hline 505 & 377CCKS & $05-08-87$ & 400 & $<.10$ & - & .60 & .38 & .21 & .03 \\
\hline 693 & $377 \mathrm{CCKS}$ & $05-29-87$ & 2,200 & $<.20$ & - & $<.60$ & - & .26 & .04 \\
\hline 703 & 377CCKS & $06-05-87$ & 230 & $<.20$ & - & $<1.0$ & -- & .14 & .02 \\
\hline 945 & 377CCKS & $11-13-86$ & 3,100 & .82 & .44 & $<1.0$ & -- & .15 & .02 \\
\hline 992 & 377HRPR & $07-28-87$ & 5,300 & 1.8 & .1 & 2.0 & .4 & $<.05$ & -- \\
\hline 1089 & 377CCKS & $06-12-87$ & 3,600 & 1.7 & .2 & 1.8 & .4 & $<.05$ & -- \\
\hline 1090 & 377CCKS & $06-17-87$ & 1,400 & 4.4 & .4 & 14 & 1.0 & $<.05$ & - \\
\hline 1091 & 377CCKS & $06-18-87$ & 3,300 & 2.6 & .3 & $<2.0$ & - & $<.05$ & - \\
\hline 1092 & 377CCKS & $06-23-87$ & 410 & .49 & .04 & 7.8 & .5 & $<.05$ & -- \\
\hline 1093 & $377 \mathrm{CCKS}$ & $06-26-87$ & 3,000 & $<.10$ & - & $<.50$ & -- & $<.05$ & -- \\
\hline 1094 & 377CCKS & $06-26-87$ & 2,100 & .50 & .01 & .56 & .03 & $<.05$ & -- \\
\hline 1095 & 377CCKS & $07-28-87$ & 5,600 & 2.6 & .1 & 3.9 & .4 & .18 & .03 \\
\hline 1096 & $377 \mathrm{CCKS}$ & $07-29-87$ & 4,800 & $<.20$ & -- & 1.4 & .4 & $<.05$ & - \\
\hline 1097 & 377ANTM & $08-04-87$ & 2,800 & .36 & .09 & $<.80$ & -- & $<.05$ & - \\
\hline 1098 & 377CCKS & $08-05-87$ & 490 & 1.4 & .1 & 3.6 & .5 & $<.05$ & -- \\
\hline 1099 & 400FLCGG & $08-06-87$ & 440 & .15 & - & .73 & - & $<.05$ & -- \\
\hline 1213 & $377 \mathrm{CCKS}$ & $07-02-87$ & 1,200 & 2.1 & .2 & 2.9 & .7 & .09 & .01 \\
\hline 1217 & 377CCKS & $06-30-87$ & 1,700 & .93 & .09 & .70 & .4 & $<.05$ & -- \\
\hline
\end{tabular}


Table 22. Chemical analyses of radionuclides in ground water in the Chickies Quartzite and adjacent geologic urits. Geologic unit codes are explained at the beginning of table 20. Counting or analytical error values for each sample give counting or analytical uncertainty at the $2 \sigma$ or 95 -percent-confidence level.--Continued

\begin{tabular}{|c|c|c|c|c|c|c|c|c|}
\hline $\begin{array}{l}\text { Gross } \\
\text { alpha, } \\
\text { dis- } \\
\text { solved } \\
\text { (pCi/L } \\
\text { as } \\
\text { U-Nat) }\end{array}$ & $\begin{array}{c}\text { Gross } \\
\text { alpha, } \\
2-\sigma \\
\text { CE } \\
\text { (pCi/L } \\
\text { as } \\
\text { U-Nat) }\end{array}$ & $\begin{array}{c}\text { Gross } \\
\text { alpha, } \\
\text { dis- } \\
\text { solved } \\
\text { ( } \mu \mathrm{g} / \mathrm{L} \\
\text { as } \\
\text { U-Nat) }\end{array}$ & $\begin{array}{c}\text { Gross } \\
\text { alpha, } \\
2-\sigma \\
\text { CE } \\
\text { ( } \mu \text { g/L } \\
\text { as } \\
\text { U-Nat) }\end{array}$ & $\begin{array}{l}\text { Gross } \\
\text { beta, } \\
\text { dis- } \\
\text { solved } \\
\text { (pCi/L } \\
\text { as } \\
\text { Cs-137) }\end{array}$ & $\begin{array}{c}\text { Gross } \\
\text { beta, } \\
2-\sigma \\
\text { CE } \\
\text { (pCi/L } \\
\text { as } \\
\text { CS-137) }\end{array}$ & $\begin{array}{c}\text { Gross } \\
\text { beta, } \\
\text { dis- } \\
\text { solved } \\
\text { (pCi/L } \\
\text { as Sr/ } \\
\text { Yt-90) }\end{array}$ & $\begin{array}{c}\text { Gross } \\
\text { beta, } \\
2-\sigma \\
\text { CE } \\
\text { (pCi/L } \\
\text { as } \\
\text { SR/YT-90) }\end{array}$ & $\begin{array}{c}\text { USG }^{\circ} \\
\text { wel } \\
\text { numbar }\end{array}$ \\
\hline 5.2 & 2.0 & - & - & 7.0 & 1.0 & - & - & $144 C \cdot \mathrm{BE}$ \\
\hline$<2.0$ & -. & -- & - & 3.6 & 1.0 & - & - & $396-\mathrm{BK}$ \\
\hline$<5.0$ & - & -. & - & 8.0 & 1.8 & -. & -- & $120 r$ \\
\hline$<2.0$ &.. & -- & -. & 4.3 & 1.1 & - & - & 1201 \\
\hline 35 & 4.0 & - & -- & 120 & 10 & - & - & $120 \pi$ \\
\hline 45 & 6.0 & - & - & 150 & 20 & - & -- & \\
\hline 6.2 & 2.5 & -. & -. & 21 & 1.0 & - & -- & $122 \%$ \\
\hline 5.0 & 2.6 & - & - & 21 & 2.0 & - & - & $122 \pi$ \\
\hline -. & - & 12 & 2.5 & 14 & 2.0 & 13 & 1.9 & $128 R$ \\
\hline 10 & 2.0 & - & -- & 18 & 2.0 & - & - & SP21 \\
\hline 1.8 & 1.6 & - & - & 7.7 & 1.2 & -- & -- & $298 \cdot \mathrm{CH}$ \\
\hline 33 & 5.0 & -. & -- & 41 & 3.0 & -. & -. & 333 \\
\hline 1.2 & .9 & - &.- & 5.0 & .9 & -- & -. & 417 \\
\hline 20 & 2.0 & -. & -. & 20 & 2.0 & -- & -. & 418 \\
\hline 1.3 & .8 & - & - & 2.9 & .8 & - & -- & 427 \\
\hline$<1.0$ & -- & - & - & 3.9 & .9 & -- & -- & 505 \\
\hline$<.7$ & -. & -. & - & 3.3 & .8 & -. & -- & 693 \\
\hline 1.2 & 1.1 & -. & -- & 5.0 & 1.0 & -- & -- & 703 \\
\hline .9 & .8 & -- & $\cdots$ & 5.1 & .9 & -. & -. & 945 \\
\hline 2.9 & 1.9 & - & -. & 9.3 & 1.3 & .. & - & 992 \\
\hline 3.2 & 1.6 & - & -- & 7.5 & 1.1 & -. & -- & 1089 \\
\hline 22 & 3.0 & -. & -- & 32 & 2.0 & -. & -. & $109 n$ \\
\hline 4.1 & 1.4 & -. & -. & 4.6 & .8 & -- & -. & 1091 \\
\hline 7.1 & 1.9 & -. & .. & 17 & 1.0 & -- & -- & $109 ?$ \\
\hline$<2.0$ & -. & - & - & 5.5 & 1.0 & -- & -- & 109.3 \\
\hline 1.5 & .8 & -. & -. & 2.6 & .7 & -- & -- & 109.4 \\
\hline 4.6 & 1.8 & - & -- & 7.8 & 1.1 & -- & - & $109=$ \\
\hline$<1.0$ & -. & -. & - & 4.6 & .9 & -- & -. & 1093 \\
\hline$<1.0$ & .- & .. & - & 5.1 & 1.0 & -- & -- & 1097 \\
\hline 2.0 & 1.1 & - & -- & 6.7 & 1.0 & -- & .. & $109^{?}$ \\
\hline$<1.0$ & - & -- & -- & 3.9 & -. & -. & -- & 1093 \\
\hline 4.3 & 1.8 & - & - & 18 & 2.0 & -. & -. & 1213 \\
\hline 1.4 & 1.1 & .. & .. & 3.9 & .8 & -- & -- & 1217 \\
\hline
\end{tabular}


Table 22. Chemical analyses of radionuclides in ground water in the Chickies Quartzite and adjacent geologic units. Geologic unit codes are explained at the beginning of table 20. Counting or analytical error values for each samnle give counting or analytical uncertainty at the $2 \sigma$ or 95 -percent-confidence level..--Continued

\begin{tabular}{|c|c|c|c|c|c|c|c|c|c|}
\hline $\begin{array}{l}\text { USGS } \\
\text { well } \\
\text { number }\end{array}$ & $\begin{array}{l}\text { Geo- } \\
\text { logic } \\
\text { unit }\end{array}$ & Date & $\begin{array}{l}\text { Radon- } \\
222, \\
\text { total } \\
(\mathrm{pCi} / \mathrm{L})\end{array}$ & $\begin{array}{l}\text { Radium- } \\
226, \\
\text { dis- } \\
\text { solved, } \\
\text { radon } \\
\text { method } \\
(\mathrm{pCi} / \mathrm{L})\end{array}$ & $\begin{array}{l}\text { Radium- } \\
226, \\
2-\sigma \\
\mathrm{CE} \\
(\mathrm{pCi} / \mathrm{L})\end{array}$ & $\begin{array}{l}\text { Radium- } \\
228, \\
\text { dis- } \\
\text { solved } \\
\text { (pCi/L } \\
\text { as } \\
\text { Ra-228) }\end{array}$ & $\begin{array}{c}\text { Radium- } \\
228 \text {, } \\
2-\sigma \\
\mathrm{CE} \\
(\mathrm{pCi} / \mathrm{L})\end{array}$ & $\begin{array}{l}\text { Uranium, } \\
\text { natural, } \\
\text { dis- } \\
\text { solved } \\
\text { ( } \mu \mathrm{g} / \mathrm{L} \\
\text { as } \mathrm{U})\end{array}$ & $\begin{array}{c}\text { Uranium, } \\
2-\sigma \\
\text { AE } \\
(\mu \mathrm{g} / \mathrm{L})\end{array}$ \\
\hline \multirow[t]{2}{*}{ CH-1265 } & 377CCKS & $11-21-86$ & 370 & 2.7 & 0.5 & 2.7 & 0.7 & 0.18 & 0.03 \\
\hline & 377CCKS & $05 / 06 / 87$ & - & 2.0 & .2 & 2.4 & .5 & .23 & .03 \\
\hline 1286 & 377CCKS & $12-01-86$ & 3,300 & .40 & .13 & 12 & 1.0 & .18 & .03 \\
\hline 1296 & $377 \mathrm{CCKS}$ & $09-02-87$ & 2,000 & 4.8 & .1 & 6.3 & 1.0 & .24 & .04 \\
\hline 1367 & 377CCKS & $08-05-87$ & 7,300 & 3.8 & .1 & 9.9 & .7 & .35 & .05 \\
\hline 1376 & 377CCKS & $09-04-87$ & 5,800 & .90 & .1 & 4.0 & .8 & .06 & .01 \\
\hline \multirow[t]{3}{*}{1616} & 377CCKS & $11-12-86$ & 3,400 & 2.5 & .6 & 26 & 3.0 & .30 & .05 \\
\hline & $377 \mathrm{CCKS}$ & $08-11-87$ & -- & 2.9 & .1 & 25 & 1.0 & $<.05$ & -- \\
\hline & 377CCKS & $10-23-87$ & 3,700 & 4.1 & .4 & 29 & 3.0 & .87 & .01 \\
\hline 1617 & 377CCKS & $06-03-87$ & 280 & 3.7 & 1.0 & 17 & 1.0 & .25 & .04 \\
\hline 1618 & 377CCKS & $05-22-87$ & 1,900 & 3.7 & 1.0 & 32 & 2.0 & .21 & .03 \\
\hline 2113 & 377CCKS & $11-10-86$ & 2,200 & 1.7 & .5 & 12 & 3.0 & .22 & .03 \\
\hline 2115 & 400BMFGA & $11-10-86$ & 1,600 & $<.60$ & -- & $<1.0$ & -- & .25 & .04 \\
\hline 2410 & 377CCKS & $11-20-86$ & 8,600 & 2.3 & .5 & 4.9 & 2.9 & .15 & .03 \\
\hline 2417 & 377CCKS & $08-26-88$ & 3,600 & .47 & .08 & $<1.0$ & -- & $<.01$ & -- \\
\hline 2418 & 377CCKS & $11-22-86$ & 1,300 & $<.70$ & -- & 2.6 & .8 & .12 & .02 \\
\hline 2828 & $367 \mathrm{CNSG}$ & $07-29-87$ & 520 & .33 & .08 & $<.50$ & -- & 2.4 & .4 \\
\hline 2847 & 377CCKS & $09-05-87$ & 3,700 & .78 & .01 & 2.9 & .4 & .08 & .01 \\
\hline 2998 & 400FLCGG & $07-16-87$ & 2,100 & $<.20$ & - & $<.70$ & - & $<.05$ & -- \\
\hline 3076 & 377CCKS & $07-16-87$ & 7,800 & 2.4 & .1 & 10 & 1.0 & .12 & .02 \\
\hline 3079 & 377HRPR & $07-27-87$ & 1,100 & .64 & .01 & $<.90$ & -- & $<.05$ & - \\
\hline 3086 & 400FCIGA & $08-07-87$ & 470 & $<.20$ & - & $<.60$ & - & $<.05$ & - \\
\hline 3087 & $377 \mathrm{CCKS}$ & $08-13-87$ & 360 & 8.7 & .2 & 32 & 2.0 & $<.05$ & -- \\
\hline 3088 & $377 \mathrm{CCKS}$ & $08-13-87$ & 7,300 & .38 & .07 & $<.70$ & - & $<.05$ & -- \\
\hline 3089 & 400FCIGA & $08-12-87$ & 140 & $<.10$ & -- & $<.90$ & -- & $<.05$ & - \\
\hline 3090 & 400FCIGA & $08-12-87$ & 2,100 & $<.20$ & - & $<.70$ & -- & $<.05$ & -- \\
\hline 3091 & $377 \mathrm{CCKS}$ & $08-12-87$ & - & 6.1 & .1 & 26 & 2.0 & 6.6 & 1.0 \\
\hline 3111 & 377CCKS & $08-26-87$ & 970 & 1.2 & .1 & 2.3 & .6 & $<.05$ & -- \\
\hline \multirow[t]{2}{*}{3112} & 377CCKS & $08-28-87$ & 590 & 8.0 & .2 & 44 & 2.0 & $<.05$ & -- \\
\hline & 377CCKS & $06-01-89$ & 750 & -. & - & - & - & - & -- \\
\hline 3113 & $377 \mathrm{CCKS}$ & $08-28-87$ & 1,300 & 4.5 & .1 & 7.7 & 1.2 & 1.1 & .02 \\
\hline 3114 & $377 \mathrm{CCKS}$ & $08-29-87$ & 590 & 5.7 & .2 & 36 & 2.0 & $<.05$ & -- \\
\hline
\end{tabular}


Table 22. Chemical analyses of radionuclides in ground water in the Chickies Quartzite and adjacent geologic uni : Geologic unit codes are explained at the beginning of table 20. Counting or analytical errorvalues for each sample give counting or analytical uncertainty at the $2 \sigma$ or 95 -percent-confidence level.--Continued

\begin{tabular}{|c|c|c|c|c|c|c|c|c|}
\hline $\begin{array}{l}\text { Gross } \\
\text { alpha, } \\
\text { dis- } \\
\text { solved } \\
\text { (pCi/L } \\
\text { as } \\
\text { U-Nat) }\end{array}$ & $\begin{array}{c}\text { Gross } \\
\text { alpha, } \\
2-\sigma \\
\mathrm{CE} \\
\text { (pCi/L } \\
\text { as } \\
\text { U-Nat) }\end{array}$ & $\begin{array}{c}\text { Gross } \\
\text { alpha, } \\
\text { dis- } \\
\text { solved } \\
\text { ( } \mu \mathrm{g} / \mathrm{L} \\
\text { as } \\
\text { U-Nat) }\end{array}$ & $\begin{array}{c}\text { Gross } \\
\text { alpha, } \\
2-\sigma \\
\text { CE } \\
\text { ( } \mu \mathrm{g} / \mathrm{L} \\
\text { as } \\
\text { U-Nat) }\end{array}$ & $\begin{array}{l}\text { Gross } \\
\text { beta, } \\
\text { dis- } \\
\text { solved } \\
\text { (pCi/L } \\
\text { as } \\
\text { Cs-137) }\end{array}$ & $\begin{array}{c}\text { Gross } \\
\text { beta, } \\
2-\sigma \\
\text { CE } \\
\text { (pCi/L } \\
\text { as } \\
\text { CS-137) }\end{array}$ & $\begin{array}{l}\text { Gross } \\
\text { beta, } \\
\text { dis- } \\
\text { solved } \\
\text { ( } \mathrm{pCi} / \mathrm{L} \\
\text { as } \mathrm{Sr} / \\
\text { Yt-90) }\end{array}$ & $\begin{array}{c}\text { Gross } \\
\text { beta, } \\
2-\sigma \\
\text { CE } \\
\text { (pCi/L } \\
\text { as } \\
\text { SR/YT-90) }\end{array}$ & $\begin{array}{c}\text { USGS } \\
\text { well } \\
\text { number }\end{array}$ \\
\hline 6.2 & 2.4 & - & - & 6.6 & 1.6 & - & - & $1265-\mathrm{CH}$ \\
\hline 2.1 & 1.8 & - & - & 5.7 & 1.1 & -. & -- & \\
\hline 13 & 3.0 & - & - & 11 & 1.0 & - & - & 1286 \\
\hline 13 & 3.0 & - & - & 12 & 1.0 & -- & -- & 1296 \\
\hline 5.6 & 1.7 & - & .- & 20 & 2.0 & -- & - & 1367 \\
\hline 3.2 & 1.5 & - & - & 8.8 & 1.1 & - & - & 1376 \\
\hline 17 & 3.0 & - & -- & 51 & 3.0 & - & - & 1616 \\
\hline 9.8 & 2.9 & - & - & 59 & 3.0 & - & - & \\
\hline 55 & 6.0 & -. & .. & 59 & 3.0 & - & - & \\
\hline 17 & 3.0 & -- & -- & 33 & 2.0 & - & -- & 1617 \\
\hline 15 & 3.0 & - & - & 79 & 3.0 & -- & - & 1618 \\
\hline 5.7 & 1.8 & - & - & 25 & 3.0 & -- & -- & 2113 \\
\hline$<1.0$ & -- & -. & - & 3.2 & .9 & -- & - & 2115 \\
\hline 4.4 & 1.9 & - & -- & 5.9 & 1.5 & -. & -. & 2410 \\
\hline- & - & 2.2 & 0.8 & 2.5 & .8 & 2.4 & 0.7 & 2417 \\
\hline 1.3 & 1.0 & -- & - & 2.2 & 1.2 & -- & - & 2418 \\
\hline$<4.0$ & - & -- & - & 3.8 & 1.3 & - & - & 2828 \\
\hline 1.7 & 1.0 & -- & -- & 6.9 & .9 & - & -. & 2847 \\
\hline$<2.0$ & - & -- & -- & 5.4 & 1.0 & -. & - & 2998 \\
\hline 9.0 & 2.7 & -- & - & 21 & 2.0 & - & - & 3076 \\
\hline$<1.0$ & - & - & - & 3.6 & .9 & - & - & 3079 \\
\hline$<2.0$ & - & -- & - & 1.4 & .8 & - & - & 3086 \\
\hline 23 & 3.0 & - & - & 49 & 2.0 & - & - & 3087 \\
\hline$<1.0$ & - & -- & - & 5.3 & .8 & - & -- & 3088 \\
\hline$<1.0$ & -- & -. & - & 2.3 & .8 & - & - & 3089 \\
\hline$<1.0$ & -. & -. & -. & 3.3 & .9 & - & - & 3090 \\
\hline 19 & 3.0 & -- & -. & 54 & 3.0 & - & -- & 3091 \\
\hline 2.8 & 1.1 & -. & -. & 4.5 & .8 & - & - & 3111 \\
\hline 27 & 4.0 & - & - & 82 & 3.0 & -- & - & 3112 \\
\hline- & -. & - & -. & - & -- & - & - & \\
\hline 6.2 & 2.3 & - & - & 15 & 1.0 & - & -- & 3113 \\
\hline 24 & 5.0 & - & - & 85 & 3.0 & - & - & 3114 \\
\hline
\end{tabular}


Table 22. Chemical analyses of radionuclides in ground water in the Chickies Quartzite and adjacent geolonic units. Geologic unit codes are explained at the beginning of table 20. Counting or analytical error values for each sample give counting or analytical uncertainty at the $2 \sigma$ or 95 -percent-confidence level.--Continued

\begin{tabular}{|c|c|c|c|c|c|c|c|c|c|}
\hline $\begin{array}{l}\text { USGS } \\
\text { well } \\
\text { number }\end{array}$ & $\begin{array}{l}\text { Geo- } \\
\text { logic } \\
\text { unit }\end{array}$ & Date & $\begin{array}{c}\text { Radon- } \\
222, \\
\text { total } \\
(\mathrm{pCi} / \mathrm{L})\end{array}$ & $\begin{array}{l}\text { Radium- } \\
226, \\
\text { dis- } \\
\text { solved, } \\
\text { radon } \\
\text { method } \\
\text { (pCi/L) }\end{array}$ & $\begin{array}{l}\text { Radium- } \\
226, \\
2-\sigma \\
\mathrm{CE} \\
(\mathrm{pCi} / \mathrm{L})\end{array}$ & $\begin{array}{l}\text { Radium- } \\
228, \\
\text { dis- } \\
\text { solved } \\
\text { (pCi/L } \\
\text { as } \\
\text { Ra-228) }\end{array}$ & $\begin{array}{l}\text { Radium- } \\
228, \\
2-\sigma \\
\mathrm{CE} \\
(\mathrm{pCi} / \mathrm{L})\end{array}$ & $\begin{array}{l}\text { Uranium, } \\
\text { natural, } \\
\text { dis- } \\
\text { solved } \\
\text { ( } \mu \mathrm{g} / \mathrm{L} \\
\text { as } \mathrm{U} \text { ) }\end{array}$ & $\begin{array}{c}\text { Uranium, } \\
2-\sigma \\
\mathbf{A E} \\
(\mu \mathrm{g} / \mathrm{L})\end{array}$ \\
\hline CH-3117 & 400FCIGA & $08-31-87$ & 8,200 & 1.1 & 0.1 & 1.4 & 0.4 & 1.7 & 0.3 \\
\hline 3122 & $377 \mathrm{CCKS}$ & $09-04-87$ & 9,200 & 1.0 & .1 & 1.8 & 1.0 & .13 & .02 \\
\hline 3123 & 377CCKS & $09-02-87$ & 6,500 & 2.1 & .1 & 8.0 & 1.1 & .55 & .08 \\
\hline 3124 & $377 \mathrm{CCKS}$ & $09-02-87$ & 3,700 & 2.4 & .3 & 2.7 & .4 & .07 & .01 \\
\hline 3125 & 377CCKS & $09-01-87$ & 630 & 5.1 & .2 & 6.9 & 1.2 & .10 & .03 \\
\hline 3126 & $377 \mathrm{CCKS}$ & $09-01-87$ & 6,900 & $<.20$ & -- & $<.80$ & -- & $<.05$ & -- \\
\hline 3127 & 377CCKS & $09-01-87$ & 6,400 & 1.2 & .1 & 6.7 & .7 & .09 & .01 \\
\hline 3128 & 377CCKS & $09-03-87$ & 1,100 & 11 & 1.0 & 30 & 3.0 & $<.05$ & -- \\
\hline 3131 & 377CCKS & $09-04-87$ & 4,700 & .68 & .07 & 3.4 & .7 & .08 & .01 \\
\hline 3132 & $377 \mathrm{CCKS}$ & $09-03-87$ & 1,400 & 31 & 2.0 & 55 & 6.0 & $<.05$ & -- \\
\hline 3133 & 377CCKS & $10-21-87$ & 4,400 & .77 & .09 & $<.80$ & -- & $<.05$ & -- \\
\hline 3135 & $377 \mathrm{CCKS}$ & $09-05-87$ & 3,800 & .38 & .01 & $<.70$ & - & $<.05$ & -- \\
\hline 3136 & 377HRPR & $09-08-87$ & 790 & 2.9 & .1 & 12 & 1.0 & $<.05$ & -- \\
\hline 3160 & 377CCKS & $08-22-88$ & 1,700 & .2 & .04 & 1.5 & .9 & $<.01$ & -- \\
\hline 3166 & 377CCKS & $10-19-87$ & 840 & 1.5 & .4 & 4.1 & .7 & $<.05$ & - \\
\hline 3168 & 377CCKS & $09-29-87$ & 700 & 2.1 & .1 & 17 & 2.0 & $<.05$ & -- \\
\hline 3189 & $377 \mathrm{CCKS}$ & $08-30-88$ & 2,700 & 4.2 & .7 & 2.4 & .8 & .03 & .01 \\
\hline 3213 & $377 \mathrm{CCKS}$ & $10-21-87$ & -- & 10 & 1.0 & 38 & 3.0 & .08 & .01 \\
\hline 3214 & 377CCKS & $10-22-87$ & 5,800 & 5.2 & .5 & 8.7 & .8 & .11 & .02 \\
\hline 3215 & $377 \mathrm{CCKS}$ & $10-23-87$ & 630 & 5.4 & .6 & 25 & 2.0 & .08 & .01 \\
\hline \multirow[t]{2}{*}{3219} & $377 \mathrm{CCKS}$ & $06-16-88$ & 670 & 4.6 & .8 & 13 & 2.7 & -- & -- \\
\hline & $377 \mathrm{CCKS}$ & $08-23-88$ & 770 & 6.2 & 1.0 & 16 & 3.1 & .02 & .01 \\
\hline 3301 & 400FMFG & $06-16-88$ & 600 & .03 & .01 & $<1.0$ & -- & .01 & .01 \\
\hline 3315 & $377 \mathrm{CCKS}$ & $09-01-88$ & 330 & 5.3 & .9 & 19 & 3.7 & .04 & .01 \\
\hline 3325 & $377 \mathrm{CCKS}$ & $08-16-88$ & 1,300 & 6.2 & 1.1 & 10 & 2.1 & .10 & .01 \\
\hline 3326 & $377 \mathrm{CCKS}$ & $08-16-88$ & 32,300 & 1.2 & .19 & $<1.0$ & .6 & 1.0 & .16 \\
\hline 3327 & $377 \mathrm{CCKS}$ & $08-26-88$ & 840 & 12 & 2.1 & 28 & 5.4 & .09 & .01 \\
\hline 3328 & 377CCKS & $08-26-88$ & 26,100 & 1.0 & .17 & $<1.0$ & - & .32 & .05 \\
\hline 3329 & 377CCKS & $08-22-88$ & 2,200 & 1.9 & .3 & $<1.0$ & -- & .04 & .01 \\
\hline 3330 & 377CCKS & $08-23-88$ & 1,500 & 3.1 & .52 & 1.9 & 1.3 & .03 & .01 \\
\hline 3331 & $377 \mathrm{CCKS}$ & $08-23-88$ & 820 & 12 & 2.0 & 160 & 29 & .07 & .01 \\
\hline
\end{tabular}


Table 22. Chemical analyses of radionuclides in ground water in the Chickies Quartzite and adjacent geologic uni': Geologic unit codes are explained at the beginning of table 20. Counting or analytical error values for each sampl? give counting or analytical uncertainty at the $2 \sigma$ or 95 -percent-confidence level.--Continued

\begin{tabular}{|c|c|c|c|c|c|c|c|c|}
\hline $\begin{array}{l}\text { Gross } \\
\text { alpha, } \\
\text { dis- } \\
\text { solved } \\
\text { (pCi/L } \\
\text { as } \\
\text { U-Nat) }\end{array}$ & $\begin{array}{c}\text { Gross } \\
\text { alpha, } \\
2-\sigma \\
\text { CE } \\
\text { (pCi/L } \\
\text { as } \\
\text { U-Nat) }\end{array}$ & 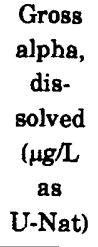 & $\begin{array}{c}\text { Gross } \\
\text { alpha, } \\
2-\sigma \\
\text { CE } \\
(\mu \mathrm{g} / \mathrm{L} \\
\text { as } \\
\text { U-Nat) }\end{array}$ & $\begin{array}{c}\text { Gross } \\
\text { beta, } \\
\text { dis- } \\
\text { solved } \\
\text { (pCi/L } \\
\text { as } \\
\text { Cs-137) }\end{array}$ & $\begin{array}{c}\text { Gross } \\
\text { beta, } \\
2-\sigma \\
\text { CE } \\
\text { (pCi/L } \\
\text { as } \\
\text { CS-137) }\end{array}$ & $\begin{array}{c}\text { Gross } \\
\text { beta, } \\
\text { dis- } \\
\text { solved } \\
\text { (pCi/L } \\
\text { as Sr/ } \\
\text { Yt-90) }\end{array}$ & $\begin{array}{c}\text { Gross } \\
\text { beta, } \\
2-\sigma \\
\text { CE } \\
\text { (pCi/L } \\
\text { as } \\
\text { SR/YT-90) }\end{array}$ & $\begin{array}{c}\text { USGS } \\
\text { well } \\
\text { numbe* }\end{array}$ \\
\hline 4.2 & 1.5 & - & -- & 5.2 & 0.9 & - & - & 3117-CH \\
\hline 2.2 & 1.2 & -- & -- & 6.7 & 1.0 & - & - & 3122 \\
\hline 6.0 & 1.6 & $-\cdot$ & -- & 17 & 1.0 & -- & -- & 3123 \\
\hline 4.4 & 1.3 & - & -- & 6.5 & .9 & -- & -- & 3124 \\
\hline 13 & 3.0 & -- & -- & 21 & 2.0 & - & -- & 3125 \\
\hline 1.3 & .8 & -- & -- & 4.8 & .8 & - & - & 3126 \\
\hline 5.6 & 2.0 & - & -. & 18 & 2.0 & -- & - & 3127 \\
\hline 32 & 4.0 & - & -- & 54 & 2.0 & -- & -- & 3128 \\
\hline 3.5 & 1.1 & - & - & 6.4 & .9 & -- & -- & 3131 \\
\hline 54 & 7.0 & -- & -- & 130 & 10 & -- & -- & 3132 \\
\hline 1.9 & .9 & - & -- & 3.4 & .7 & - & -- & 3133 \\
\hline$<1.0$ & - & -- & - & 3.2 & .8 & - & - & 3135 \\
\hline 6.1 & 1.9 & -- &.- & 16 & 1.0 & -- & -- & 3136 \\
\hline-- & - & 0.8 & 0.6 & 2.1 & .8 & 2.0 & -- & 3160 \\
\hline 4.9 & 1.3 & - & -- & 6.4 & .9 & - & -- & 3166 \\
\hline 12 & 2.0 & - & -- & 29 & 2.0 & -- & -- & 3168 \\
\hline- & - & 19 & 3.0 & 6.3 & 1.6 & 6.0 & 1.1 & 3189 \\
\hline 55 & 6.0 & -- & -- & 58 & 3.0 & -- & -- & 3213 \\
\hline 10 & 3.0 & -- & -- & 15 & 1.0 & - & -- & 3214 \\
\hline 26 & 5.0 & - & - & 47 & 3.0 & - & -- & 3215 \\
\hline -- & -. & 19 & 3.0 & 11 & 2.6 & 11 & 1.6 & 3219 \\
\hline$-\cdot$ & - & 49 & 6.1 & 30 & 6.4 & 28 & 3.3 & \\
\hline-- & -- & .4 & .4 & .9 & .6 & .93 & .5 & 3301 \\
\hline -- & -. & 53 & 6.6 & 39 & 4.7 & 37 & 4.5 & 3315 \\
\hline-- & - & 48 & 6.2 & 22 & 4.5 & 20 & 2.5 & 3325 \\
\hline-- & - & 13 & 2.5 & 16 & 3.3 & 14 & 1.9 & 3326 \\
\hline- & -- & 92 & 10 & 40 & 7.7 & 38 & 4.2 & 3327 \\
\hline- & -. & 8.8 & 1.9 & 10 & 1.7 & 9.8 & 1.6 & 3328 \\
\hline-- & $\cdots$ & 6.0 & 1.5 & 4.1 & 1.2 & 4.0 & .9 & 3329 \\
\hline- & - & 16 & 2.7 & 5.1 & 1.4 & 4.8 & 1.0 & 3330 \\
\hline -- & -- & 250 & 25 & 230 & 44 & 190 & 36 & 3331 \\
\hline
\end{tabular}


Table 22. Chemical analyses of radionuclides in ground water in the Chickies Quartzite and adjacent geologic units. Geologic unit codes are explained at the beginning of table 20. Counting or analytical error values for each sample give counting or analytical uncertainty at the $2 \sigma$ or 95 -percent-confidence level.--Continu'ed

\begin{tabular}{|c|c|c|c|c|c|c|c|c|c|}
\hline $\begin{array}{l}\text { USGS } \\
\text { well } \\
\text { number }\end{array}$ & $\begin{array}{c}\text { Geo- } \\
\text { logic } \\
\text { unit }\end{array}$ & Date & $\begin{array}{l}\text { Radon- } \\
222, \\
\text { total } \\
(\mathrm{pCi} / \mathrm{L})\end{array}$ & $\begin{array}{l}\text { Radium- } \\
226, \\
\text { dis- } \\
\text { solved, } \\
\text { radon } \\
\text { method } \\
\text { (pCi/L) }\end{array}$ & $\begin{array}{l}\text { Radium- } \\
226, \\
2-\sigma \\
\mathrm{CE} \\
(\mathrm{pCi} / \mathrm{L})\end{array}$ & $\begin{array}{l}\text { Radium- } \\
228, \\
\text { dis- } \\
\text { solved } \\
\text { (pCi/L } \\
\text { as } \\
\text { Ra-228) }\end{array}$ & $\begin{array}{c}\text { Radium- } \\
\text { 228, } \\
2-\sigma \\
\mathrm{CE} \\
(\mathrm{pCi} / \mathrm{L})\end{array}$ & $\begin{array}{l}\text { Uranium, } \\
\text { natural, } \\
\text { dis- } \\
\text { solved } \\
\text { ( } \mu \mathrm{g} / \mathrm{L} \\
\text { as } \mathrm{U})\end{array}$ & $\begin{array}{c}\text { Uranium, } \\
2-\sigma \\
\text { AE } \\
(\mu g / L)\end{array}$ \\
\hline CH-3332 & 377ANTM & $08-30-88$ & 25,800 & 0.08 & 0.02 & 1.3 & 0.8 & $<0.01$ & - \\
\hline 3333 & $377 \mathrm{CCKS}$ & $09-06-88$ & 2,800 & 3.7 & .6 & 25 & 4.8 & .17 & 0.03 \\
\hline 3334 & 377CCKS & $09-06-88$ & 1,300 & 1.1 & .2 & 12 & 2.6 & .01 & .01 \\
\hline \multirow[t]{14}{*}{3335} & $377 \mathrm{CCKS}$ & $09-06-88$ & 5,500 & 14 & 2.3 & 150 & 27 & .21 & .03 \\
\hline & 377CCKS & $11-28-88$ & 6,700 & -- & -. & -- & -. & - & -- \\
\hline & 377CCKS & $12-28-88$ & 7,500 & 13.7 & .1 & 130 & 1.0 & -- & - \\
\hline & $377 \mathrm{CCKS}$ & $01-31-89$ & 7,900 & 15.3 & .1 & 160 & 2.0 & - & - \\
\hline & 377CCKS & $02-28-89$ & 5,800 & 10.7 & .1 & 130 & 1.0 & - & - \\
\hline & 377CCKS & $03-30-89$ & 3,600 & 6.9 & .1 & 86 & 1.0 & -. & - \\
\hline & 377CCKS & $05-01-89$ & 3,800 & 6.6 & .1 & 81 & 1.0 & -- & - \\
\hline & 377CCKS & $05-31-89$ & 2,800 & 4.4 & .1 & 64 & 1.0 & - & - \\
\hline & 377CCKS & $06-28-89$ & 4,300 & 6.2 & .1 & 81 & 1.0 & - & - \\
\hline & $377 \mathrm{CCKS}$ & $07-31-89$ & 4,300 & 6.1 & .1 & 82 & 1.0 & -- & -- \\
\hline & $377 \mathrm{CCKS}$ & $08-29-89$ & 4,800 & 8.4 & .1 & 100 & 1.0 & - & -- \\
\hline & 377CCKS & $09-29-89$ & 6,300 & 10.1 & .1 & 120 & 1.0 & -- & -- \\
\hline & 377CCKS & $10-30-89$ & 6,100 & 10.9 & .1 & 120 & 1.0 & -- & - \\
\hline & $377 \mathrm{CCKS}$ & $11-27-89$ & 6,900 & 12 & .1 & 140 & 1.0 & - & -- \\
\hline 3336 & 377CCKS & $09-06-88$ & 490 & .06 & .02 & $<1.0$ & - & $<.01$ & -- \\
\hline 3337 & $377 \mathrm{CCKS}$ & $09-08-88$ & 30,600 & .72 & .15 & $<1.0$ & -- & .04 & .01 \\
\hline 3338 & $377 \mathrm{CCKS}$ & $09-08-88$ & 2,400 & 4.6 & .8 & 15 & 3.0 & .14 & .02 \\
\hline 3339 & 377CCKS & $09-09-88$ & 5,400 & 1.2 & .2 & 1.5 & .8 & .10 & .02 \\
\hline SP33 & 377HRPR & $07-27-87$ & - & 1.3 & .4 & 2.7 & .6 & $<.05$ & -- \\
\hline LN-1684 & $377 \mathrm{CCKS}$ & $11-21-86$ & 980 & 1.9 & .4 & 5.3 & 2.2 & .14 & .02 \\
\hline 1685 & 377CCKS & $12-03-86$ & 5,700 & 3.9 & .6 & 5.0 & 1.5 & .54 & .08 \\
\hline 1686 & 377CCKS & $12-03-86$ & 24,500 & 1.0 & .5 & 1.6 & .7 & .31 & .05 \\
\hline 1687 & 377CCKS & $12-04-86$ & 7,600 & 2.7 & .5 & 5.3 & .9 & .25 & .04 \\
\hline 1688 & 377CCKs & $12-04-86$ & 1,900 & 7.4 & .7 & 34 & 4.0 & .23 & .03 \\
\hline 1689 & $377 \mathrm{CCKS}$ & $12-08-86$ & 11,800 & 1.4 & .4 & 6.8 & 2.2 & .75 & .11 \\
\hline 1690 & 377CCKS & $12-08-86$ & 2,800 & 1.1 & .4 & 1.1 & .5 & .50 & .08 \\
\hline 1691 & 377CCKS & $12-12-86$ & 510 & .56 & .39 & $<.50$ & - & .86 & .13 \\
\hline 1692 & 377CCKS & $12-30-86$ & 4,400 & .84 & .27 & 1.1 & .5 & .36 & .05 \\
\hline
\end{tabular}


Table 22. Chemical analyses of radionuclides in ground water in the Chickies Quartzite and adjacent geologic unir: Geologic unit codes are explained at the beginning of table 20. Counting or analytical error values for each sample give counting or analytical uncertainty at the $2 \sigma$ or 95 -percent-confidence level.--Continued

\begin{tabular}{|c|c|c|c|c|c|c|c|c|}
\hline $\begin{array}{l}\text { Gross } \\
\text { alpha, } \\
\text { dis- } \\
\text { solved } \\
\text { (pCi/L } \\
\text { as } \\
\text { U-Nat) }\end{array}$ & $\begin{array}{c}\text { Gross } \\
\text { alpha, } \\
2-\sigma \\
\text { CE } \\
\text { (pCi/L } \\
\text { as } \\
\text { U-Nat) }\end{array}$ & $\begin{array}{c}\text { Gross } \\
\text { alpha, } \\
\text { dis- } \\
\text { solved } \\
(\mu g / L \\
\text { as } \\
\text { U-Nat) }\end{array}$ & $\begin{array}{c}\text { Gross } \\
\text { alpha, } \\
2-\sigma \\
\text { CE } \\
(\mu g / L \\
\text { as } \\
\text { U-Nat) }\end{array}$ & $\begin{array}{c}\text { Gross } \\
\text { beta, } \\
\text { dis- } \\
\text { solved } \\
\text { (pCi/L } \\
\text { as } \\
\text { Cs-137) }\end{array}$ & $\begin{array}{c}\text { Gross } \\
\text { beta, } \\
2-\sigma \\
\text { CE } \\
\text { (pCi/l } \\
\text { as } \\
\text { CS-137) }\end{array}$ & $\begin{array}{l}\text { Gross } \\
\text { beta, } \\
\text { dis- } \\
\text { solved } \\
\text { (pCi/L } \\
\text { as } \mathrm{Sr} / \\
\text { Yt-90) }\end{array}$ & $\begin{array}{c}\text { Gross } \\
\text { beta, } \\
2-\sigma \\
\text { CE } \\
\text { (pCi/L } \\
\text { as } \\
\text { SR/YT-90) }\end{array}$ & $\begin{array}{c}\text { USGS } \\
\text { well } \\
\text { number }\end{array}$ \\
\hline- & - & 1.4 & 0.8 & 4.2 & 1.0 & 3.7 & 0.9 & $3332-\mathrm{CH}$ \\
\hline- & - & 46 & 6.1 & 51 & 6.0 & 47 & 5.5 & 3333 \\
\hline- & -- & 16 & 2.8 & 24 & 3.0 & 23 & 3.0 & 3334 \\
\hline- & - & - & - & -- & - & -- & -- & 3335 \\
\hline- & - & -- & - & -- & - & -- & -- & \\
\hline- & - & - & - & -- & - & -- & - & \\
\hline- & - & -- & - & -- & -- & -- & -- & \\
\hline- & - & - & -- & $\because$ & -- & - & - & \\
\hline- & - & - & -- & -- & -- & -- & -- & \\
\hline- & - & -- & -- & - & -- & -- & -- & \\
\hline- & - & -- & -- & -- & -. &.- & -- & \\
\hline$\cdots$ & - & -- & -- & -- & -- & -- & -. & \\
\hline-- & - & - & - & -- & -- & -- & -- & \\
\hline$\cdots$ & -- & - & -- & - & - & -- & -- & \\
\hline -- & - & - & -- & -. & -- & - & -- & \\
\hline -- & - & -- & - & -- & - & - & - & \\
\hline-- & -- & $<.4$ & - & 1.9 & .8 & 1.6 & .6 & 3336 \\
\hline-- & - & 5.4 & 1.5 & 9.7 & 2.3 & 9.3 & 1.4 & 3337 \\
\hline- & - & 46 & 6.4 & 31 & 6.0 & 27 & 3.0 & 3338 \\
\hline- & -- & 5.5 & 1.7 & 6.7 & 1.3 & 6.0 & 1.1 & 3339 \\
\hline 3.7 & 1.4 & - & - & 4.7 & .9 & -- & - & SP33 \\
\hline 2.7 & 1.2 & - & - & 3.0 & 1.2 & - & - & $1684-\mathrm{LN}$ \\
\hline 7.5 & 3.9 & - & - & 24 & 2.0 & - & - & 1685 \\
\hline 4.0 & 1.2 & - & - & 9.7 & 1.1 & - & - & 1686 \\
\hline 4.8 & 1.4 & $\cdots$ & - & 7.5 & 1.0 & - & - & 1687 \\
\hline 20 & 4.0 & -- & - & 73 & 3.0 & - & - & 1688 \\
\hline 4.5 & 2.0 & 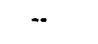 & - & 12 & 1.0 & - & - & 1689 \\
\hline 2.1 & 1.3 & -- & -- & 9.0 & 1.2 & - & - & 1690 \\
\hline$<1.0$ & - & - & - & 1.5 & .8 & - & - & 1691 \\
\hline 3.7 & 1.5 & - & - & 6.5 & 1.1 & - & - & 1692 \\
\hline
\end{tabular}


Table 22. Chemical analyses of radionuclides in ground water in the Chickies Quartzite and adjacent geologic, units. Geologic unit codes are explained at the beginning of table 20. Counting or analytical error values for each sample give counting or analytical uncertainty at the $2 \sigma$ or 95 -percent-confidence level.--Continued

\begin{tabular}{|c|c|c|c|c|c|c|c|c|c|}
\hline $\begin{array}{l}\text { USGS } \\
\text { well } \\
\text { number }\end{array}$ & $\begin{array}{l}\text { Geo- } \\
\text { logic } \\
\text { unit }\end{array}$ & Date & $\begin{array}{l}\text { Radon- } \\
222, \\
\text { total } \\
(\mathrm{pCi} / \mathrm{L})\end{array}$ & $\begin{array}{l}\text { Radium- } \\
226, \\
\text { dis- } \\
\text { solved, } \\
\text { radon } \\
\text { method } \\
(\mathrm{pCi} / \mathrm{L})\end{array}$ & $\begin{array}{l}\text { Radium- } \\
226 \\
2-\sigma \\
\mathrm{CE} \\
(\mathrm{pCi} / \mathrm{L})\end{array}$ & $\begin{array}{l}\text { Radium- } \\
228, \\
\text { dis- } \\
\text { solved } \\
\text { (pCi/L } \\
\text { as } \\
\text { Ra-228) }\end{array}$ & $\begin{array}{l}\text { Radium- } \\
228 \\
2-\sigma \\
\mathrm{CE} \\
(\mathrm{pCi} / \mathrm{L})\end{array}$ & $\begin{array}{c}\text { Uranium, } \\
\text { natural, } \\
\text { dis- } \\
\text { solved } \\
\text { ( } \mu \mathrm{g} / \mathrm{L} \\
\text { as } U \text { ) }\end{array}$ & $\begin{array}{c}\text { Uranium, } \\
2-\sigma \\
\mathrm{AE} \\
(\mu \mathrm{g} / \mathrm{L})\end{array}$ \\
\hline LN-1693 & $377 \mathrm{CCKS}$ & $12-30-86$ & 3,400 & 0.26 & 0.06 & $<0.50$ & -- & 0.40 & 0.06 \\
\hline 1694 & 377CCKS & $12-30-86$ & 500 & 1.6 & .3 & 5.2 & 0.5 & .34 & .05 \\
\hline 1695 & $377 \mathrm{CCKS}$ & $12-30-86$ & 2,000 & 2.3 & .3 & 4.0 & .5 & .33 & .05 \\
\hline 1696 & 377CCKS & $07-08-87$ & 480 & 5.0 & .5 & 16 & 1.0 & .06 & .01 \\
\hline 1697 & $377 \mathrm{CCKS}$ & $07-13-87$ & 600 & 6.6 & .7 & 100 & 10 & .27 & .04 \\
\hline 1698 & $377 \mathrm{CCKS}$ & $07-13-87$ & 1,000 & 6.3 & .6 & 33 & 1.0 & .16 & .02 \\
\hline 1699 & $377 \mathrm{CCKS}$ & $07-14-87$ & 1,600 & .49 & .07 & .68 & .39 & $<.05$ & -- \\
\hline 1700 & $377 \mathrm{CCKS}$ & $07-15-87$ & 1,400 & .42 & .01 & 1.2 & .4 & $<.05$ & -- \\
\hline 1701 & $377 \mathrm{CCKS}$ & $07-15-87$ & 5,300 & .87 & .09 & .75 & .04 & $<.05$ & -- \\
\hline 1713 & 377CCKS & $09-01-88$ & 1,700 & 1.0 & .2 & 2.0 & .9 & .02 & .01 \\
\hline 1714 & $377 \mathrm{CCKS}$ & $08-25-88$ & 4,800 & 2.2 & .4 & 4.5 & 1.3 & .06 & .01 \\
\hline 1715 & $377 \mathrm{CCKS}$ & $08-27-88$ & 3,100 & 1.0 & .2 & $<1.0$ & - & .04 & .01 \\
\hline 1716 & 377CCKS & $08-25-88$ & 3,200 & 1.8 & .3 & 1.2 & .7 & .02 & .01 \\
\hline 1717 & $377 \mathrm{CCKS}$ & $08-03-88$ & 6,500 & 19 & 3 & 30 & 6.0 & .31 & .05 \\
\hline 1718 & 377ANTM & $08-03-88$ & 1,300 & .15 & .03 & $<1.0$ & -- & .01 & -- \\
\hline 1719 & $377 \mathrm{CCKS}$ & $08-03-88$ & 8,000 & 4.5 & .7 & 11 & 2.3 & .07 & .01 \\
\hline 1720 & 377HRPR & $08-03-88$ & 1,500 & .25 & .05 & $<1.0$ & -- & $<.01$ & -- \\
\hline 1721 & 377CCKS & $08-04-88$ & 1,000 & 9.5 & 1.6 & 79 & 14 & - & -. \\
\hline 1722 & $377 \mathrm{CCKS}$ & $08-04-88$ & 2,700 & .10 & .02 & $<1.0$ & -- & .04 & .01 \\
\hline 1723 & $377 \mathrm{CCKS}$ & $08-04-88$ & 2,700 & .20 & .04 & $<1.0$ & - & .03 & .01 \\
\hline 1724 & 377CCKS & $08-05-88$ & 2,600 & 6.3 & 1.1 & 10 & 2.5 & .06 & .01 \\
\hline 1725 & $377 \mathrm{CCKS}$ & $08-05-88$ & 12,700 & 41 & 7 & 106 & 20 & .74 & .11 \\
\hline 1726 & $377 \mathrm{CCKS}$ & $08-05-88$ & 4,300 & 6.2 & 1.0 & 13 & 3.1 & .11 & .02 \\
\hline 1727 & $377 \mathrm{CCKS}$ & $08-08-88$ & 3,300 & .87 & .15 & 1.0 & .6 & .02 & .01 \\
\hline 1728 & 377CCKS & 08-08-88 & 2,000 & 1.0 & .17 & 1.2 & .7 & .03 & .01 \\
\hline 1730 & $367 \mathrm{CNSG}$ & $08-13-88$ & 65 & .02 & .01 & $<1.0$ & -- & .15 & .02 \\
\hline 1731 & $377 \mathrm{CCKS}$ & $08-13-88$ & 17,900 & 1.5 & .3 & 2.5 & 1.0 & .58 & .09 \\
\hline 1732 & 377CCKS & $08-15-88$ & 3,300 & 9.2 & 1.6 & 14 & 2.8 & .13 & .02 \\
\hline 1733 & 377ANTM & $08-15-88$ & 2,300 & .06 & .02 & $<1.0$ & -- & $<.01$ & -- \\
\hline 1734 & $377 \mathrm{CCKS}$ & $08-25-88$ & 3,900 & 1.4 & .2 & $<1.0$ & - & .06 & .01 \\
\hline 1735 & 377CCKS & $08-17-88$ & 2,100 & 2.2 & .4 & 1.8 & 1.4 & .04 & .01 \\
\hline 1736 & 377CCKS & $08-17-88$ & 770 & .61 & .11 & 3.7 & 1.3 & .02 & .01 \\
\hline
\end{tabular}


Table 22. Chemical analyses of radionuclides in ground water in the Chickies Quartzite and adjacent geologic units. Geologic unit codes are explained at the beginning of table 20. Counting or analytical error values for each sample. give counting or analytical uncertainty at the $2 \sigma$ or 95 -percent-confidence level.--Continued

\begin{tabular}{|c|c|c|c|c|c|c|c|c|}
\hline $\begin{array}{l}\text { Gross } \\
\text { alpha, } \\
\text { dis- } \\
\text { solved } \\
\text { (pCi/L } \\
\text { as } \\
\text { U-Nat) }\end{array}$ & $\begin{array}{c}\text { Gross } \\
\text { alpha, } \\
2-\sigma \\
\text { CE } \\
\text { (pCi/L } \\
\text { as } \\
\text { U-Nat) }\end{array}$ & $\begin{array}{c}\text { Gross } \\
\text { alpha, } \\
\text { dis- } \\
\text { solved } \\
\text { ( } \mu \mathrm{g} / \mathrm{L} \\
\text { as } \\
\text { U-Nat) }\end{array}$ & $\begin{array}{c}\text { Gross } \\
\text { alpha, } \\
2-\sigma \\
\text { CE } \\
\text { ( } \mu g / L \\
\text { as } \\
\text { U-Nat) }\end{array}$ & $\begin{array}{l}\text { Gross } \\
\text { beta, } \\
\text { dis- } \\
\text { solved } \\
\text { (pCi/L } \\
\text { as } \\
\text { Cs-137) }\end{array}$ & $\begin{array}{c}\text { Gross } \\
\text { beta, } \\
2-\sigma \\
\text { CE } \\
\text { (pCi/L } \\
\text { as } \\
\text { CS-137) }\end{array}$ & $\begin{array}{c}\text { Gross } \\
\text { beta, } \\
\text { dis- } \\
\text { solved } \\
\text { (pCi/L } \\
\text { as } \mathrm{Sr} / \\
\mathrm{Yt-90)}\end{array}$ & $\begin{array}{c}\text { Gross } \\
\text { beta, } \\
2-\sigma \\
\text { CE } \\
\text { (pCi/L } \\
\text { as } \\
\text { SRYTT-90) }\end{array}$ & $\begin{array}{c}\text { USGS } \\
\text { well } \\
\text { number }\end{array}$ \\
\hline$<0.8$ & -- & - & -- & 3.4 & 0.7 & -- & - & $1693-\mathrm{I} / \mathrm{N}$ \\
\hline 7.7 & 1.8 & -- & -- & 14 & 1.0 & -- & - & 1694 \\
\hline 7.6 & 1.7 & -- & -- & 9.1 & 1.1 & - & - & 1695 \\
\hline 11 & 2.0 & -- & -- & 33 & 2.0 & - & - & 1696 \\
\hline 150 & 3.0 & -- & -- & 210 & 10 & - & - & 1697 \\
\hline 36 & 5.0 & -- & -- & 79 & 3.0 & - & - & 1698 \\
\hline 1.1 & .6 & -- & - & 2.1 & .6 & -- & -- & 1699 \\
\hline 1.7 & .8 & -- & -- & 2.0 & .6 & - & - & 1700 \\
\hline 1.2 & .9 & - & - & 5.6 & .9 & -- & - & 1701 \\
\hline 6.1 & 1.6 & - & -- & 3.4 & 1.0 & 3.2 & 0.8 & 1713 \\
\hline 16 & 3.0 & - & - & 8.7 & 2.1 & 7.9 & 1.5 & 1714 \\
\hline 6.3 & 1.6 & - & - & 4.6 & 1.0 & 4.4 & 1.0 & 1715 \\
\hline 6.6 & 1.6 & - & -- & 5.2 & 1.1 & 5.2 & 1.0 & 1716 \\
\hline 110 & 13 & -- & - & 56 & 11 & 43 & 10 & 1717 \\
\hline 1.8 & 1.3 & -- & -- & 5.4 & 1.4 & 4.3 & 1.0 & 1718 \\
\hline 31 & 4.0 & -- & - & 23 & 4.6 & 16. & 2.6 & 1719 \\
\hline 1.1 & .9 & - & - & 3.5 & 1.1 & 2.9 & .8 & 1720 \\
\hline 150 & 16 & - & - & 140 & 25 & 110 & 11 & 1721 \\
\hline 1.2 & .8 & -- & -- & 4.5 & 1.3 & 4.0 & 1.0 & 1722 \\
\hline 1.6 & .9 & -- & - & 3.5 & 1.1 & 3.1 & .8 & 1723 \\
\hline 33 & 5.0 & -- & -- & 18 & 4.0 & 16 & 3.0 & 1724 \\
\hline 250 & 25 & -- & - & 160 & 31 & 130 & 13 & 1725 \\
\hline 35 & 4.6 & -- & - & 23 & 4.6 & 22 & 2.6 & 1726 \\
\hline 6.5 & 1.6 & -- & - & 4.6 & 1.2 & 4.3 & .9 & 1727 \\
\hline -- & - & 8.3 & 1.9 & 5.7 & 1.5 & 5.3 & 1.2 & 1728 \\
\hline- & -- & $<.4$ & - & 2.3 & .9 & 1.8 & .7 & 1730 \\
\hline- & -- & 20 & 3.5 & 18 & 2.6 & 16 & 2.2 & 1731 \\
\hline- & -- & 78 & 9.0 & 50 & 6.0 & 46 & 5.0 & 1732 \\
\hline- & -- & .8 & .6 & 3.1 & 1.0 & 2.9 & .8 & 1733 \\
\hline-- & -- & 5.9 & 1.7 & 6.6 & $1.7^{\circ}$ & 5.5 & 1.1 & 1734 \\
\hline-- & -- & 12 & 2.4 & 7.9 & 1.4 & 7.3 & 1.3 & 1735 \\
\hline -. & -- & 7.3 & 1.8 & 4.7 & 1.3 & 4.6 & 1.0 & 1736 \\
\hline
\end{tabular}


Table 22. Chemical analyses of radionuclides in ground water in the Chickies Quartzite and adjacent geologic units. Geologic unit codes are explained at the beginning of table 20. Counting or analytical error values for each sample give counting or analytical uncertainty at the $2 \sigma$ or 95 -percent-confidence level.--Continued

\begin{tabular}{|c|c|c|c|c|c|c|c|c|c|}
\hline $\begin{array}{l}\text { USGS } \\
\text { well } \\
\text { number }\end{array}$ & $\begin{array}{l}\text { Geo- } \\
\text { logic } \\
\text { unit }\end{array}$ & Date & $\begin{array}{l}\text { Radon- } \\
222, \\
\text { total } \\
(\mathrm{pCi} / \mathrm{L})\end{array}$ & $\begin{array}{l}\text { Radium- } \\
226, \\
\text { dis- } \\
\text { solved, } \\
\text { radon } \\
\text { method } \\
(\mathrm{pCi} / \mathrm{L})\end{array}$ & $\begin{array}{l}\text { Radium- } \\
226, \\
2-\sigma \\
\mathrm{CE} \\
(\mathrm{pCi} / \mathrm{L})\end{array}$ & $\begin{array}{l}\text { Radium- } \\
228, \\
\text { dis- } \\
\text { solved } \\
\text { (pCi/L } \\
\text { as } \\
\text { Ra-228) }\end{array}$ & $\begin{array}{l}\text { Radium- } \\
228, \\
2-\sigma \\
\mathrm{CE} \\
(\mathrm{pCi} / \mathrm{L})\end{array}$ & $\begin{array}{l}\text { Uranium, } \\
\text { natural, } \\
\text { dis- } \\
\text { solved } \\
\text { ( } \mu \mathrm{g} / \mathrm{L} \\
\text { as U) }\end{array}$ & $\begin{array}{c}\text { Uranium, } \\
2-\sigma \\
A E \\
(\mu g / L)\end{array}$ \\
\hline LN-1737 & $377 \mathrm{CCKS}$ & $08-17-88$ & 2,800 & 2.2 & 0.4 & 2.7 & 1.3 & 0.06 & 0.01 \\
\hline 1738 & 377CCKS & $09-02-88$ & 2,000 & 3.9 & .7 & 14 & 2.8 & $<.01$ & -- \\
\hline 1739 & $377 \mathrm{CCKS}$ & $09-01-88$ & 770 & 5.1 & 1.0 & 29 & 5.7 & .08 & .01 \\
\hline 1740 & 377CCKS & $09-02-88$ & 1,300 & .32 & .06 & $<1.0$ & -- & .01 & -- \\
\hline 1741 & 377CCKS & $09-02-88$ & 1,500 & .22 & .04 & $<1.0$ & -- & .11 & .01 \\
\hline 1742 & O00GBBR & $09-02-88$ & 8,000 & .09 & .02 & $<1.0$ & -- & $<.01$ & -- \\
\hline MG- 399 & 377CCKS & $07-01-87$ & 2,600 & .52 & .09 & $<.60$ & -- & .09 & .01 \\
\hline 1000 & $377 \mathrm{CCKS}$ & $12-19-86$ & 840 & $<.20$ & -- & $<1.0$ & -- & .14 & .02 \\
\hline 1001 & 377CCKS & $12-29-86$ & 160 & $<.20$ & -- & .83 & .45 & .18 & .03 \\
\hline 1002 & 377LDGR & $01-08-87$ & 370 & $<.10$ & -- & $<.50$ & -- & .36 & .05 \\
\hline 1003 & 377LDGR & $01-09-87$ & 86 & $<1.0$ & -- & $<.7$ & -- & .42 & .06 \\
\hline 1004 & 337CCKS & $01-13-87$ & 2,700 & .40 & .07 & 1.1 & .4 & .38 & .06 \\
\hline YO- 88 & $377 \mathrm{CCKS}$ & $07-21-87$ & 6,800 & .40 & .09 & $<.60$ & -- & .06 & .01 \\
\hline 351 & $377 \mathrm{CCKS}$ & $08-10-88$ & 1,400 & .17 & .03 & $<1.0$ & -- & .01 & .01 \\
\hline 371 & $377 \mathrm{CCKS}$ & $12-23-86$ & 1,200 & .34 & .07 & $<.60$ & -- & .36 & .05 \\
\hline 650 & 377CCKS & $08-11-88$ & 4,000 & .37 & .06 & $<1.0$ & -- & .01 & .01 \\
\hline 792 & $377 \mathrm{CCKS}$ & $12-22-86$ & 2,900 & .85 & .36 & 1.5 & .4 & .18 & .03 \\
\hline 1148 & 377CCKS & $12-09-86$ & 20,300 & 5.4 & .6 & 9.0 & .9 & .86 & .13 \\
\hline & $377 \mathrm{CCKS}$ & $07-22-87$ & 28,500 & 2.1 & .1 & 4.0 & .7 & .79 & .12 \\
\hline 1149 & 377CCKS & $12-09-86$ & 790 & .62 & .42 & .70 & -- & .75 & .11 \\
\hline 1150 & 377CCKS & $12-09-86$ & 1,400 & $<.20$ & -- & $<1.0$ & -- & .23 & .03 \\
\hline 1151 & 377CCKS & $12-10-86$ & 1,000 & .58 & .09 & $<1.0$ & -- & .19 & .03 \\
\hline 1152 & $377 \mathrm{CCKS}$ & $12-10-86$ & 180 & $<.20$ & -- & $<1.0$ & -- & .44 & .07 \\
\hline 1153 & $377 \mathrm{CCKS}$ & $12-10-86$ & 1,200 & 1.0 & .4 & $<.70$ & -- & .75 & .11 \\
\hline 1154 & 377CCKS & $12-11-86$ & 2,600 & 1.0 & .4 & $<.90$ & -- & .38 & .06 \\
\hline 1155 & 377CCKS & $12-11-86$ & 2,200 & $<.20$ & -- & $<.90$ & - & .86 & .13 \\
\hline 1156 & $377 \mathrm{CCKS}$ & $12-11-86$ & 3,000 & $<.20$ & - & 5.6 & 1.8 & .75 & .11 \\
\hline 1157 & 377CCKS & $12-22-86$ & 2,100 & 4.7 & .2 & 6.4 & 1.9 & .37 & .06 \\
\hline 1158 & 377CCKS & $12-23-86$ & 1,400 & $<.20$ & -- & $<.90$ & - & $<.24$ & .04 \\
\hline 1159 & $377 \mathrm{CCKS}$ & $12-23-86$ & 3,500 & $<.20$ & -- & $<1.0$ & -- & .26 & .04 \\
\hline 1160 & 377HRPR & $12-23-86$ & 2,600 & $<.10$ & -- & $<.60$ & -- & .18 & .03 \\
\hline 1161 & 377CCKS & $12-24-86$ & 500 & $<.10$ & -- & $<1.0$ & - & .19 & .03 \\
\hline
\end{tabular}


Tabie 22. Chemical analyses of radionuclides in ground water in the Chickies Quartzite and adjacent geologic uni : Geologic unit codes are explained at the beginning of table 20. Counting or analytical error values for each sample give counting or analytical uncertainty at the $2 \sigma$ or 95 -percent-confidence level.--Continued

\begin{tabular}{|c|c|c|c|c|c|c|c|c|}
\hline $\begin{array}{l}\text { Gross } \\
\text { alpha, } \\
\text { dis- } \\
\text { solved } \\
\text { (pCi/L } \\
\text { as } \\
\text { U-Nat) }\end{array}$ & $\begin{array}{l}\text { Gross } \\
\text { alpha, } \\
2-\sigma \\
\text { CE } \\
\text { (pCi/L } \\
\text { as } \\
\text { U-Nat) }\end{array}$ & $\begin{array}{l}\text { Gross } \\
\text { alpha, } \\
\text { dis- } \\
\text { solved } \\
\text { ( } \mu \mathrm{g} / \mathrm{L} \\
\text { as } \\
\text { U-Nat) }\end{array}$ & $\begin{array}{c}\text { Gross } \\
\text { alpha, } \\
2-\sigma \\
\text { CE } \\
\text { ( } \mu \mathrm{g} / \mathrm{L} \\
\text { as } \\
\text { U-Nat) }\end{array}$ & $\begin{array}{c}\text { Gross } \\
\text { beta, } \\
\text { dis- } \\
\text { solved } \\
\text { (pCi/L } \\
\text { as } \\
\text { Cs-137) }\end{array}$ & $\begin{array}{c}\text { Gross } \\
\text { beta, } \\
2-\sigma \\
\text { CE } \\
\text { (pCi/L } \\
\text { as } \\
\text { CS-137) }\end{array}$ & $\begin{array}{c}\text { Gross } \\
\text { beta, } \\
\text { dis- } \\
\text { solved } \\
\text { (pCi/L } \\
\text { as } \mathrm{Sr} / \\
\mathrm{Yt-90)}\end{array}$ & $\begin{array}{c}\text { Gross } \\
\text { beta, } \\
2-\sigma \\
\text { CE } \\
\text { (pCi/L } \\
\text { as } \\
\text { SR/YT-90) }\end{array}$ & $\begin{array}{c}\text { USGS } \\
\text { well } \\
\text { numbe* }\end{array}$ \\
\hline- & -. & 15 & 2.6 & 5.8 & 1.5 & 5.5 & 1.1 & $1737-1 \mathrm{~N}$ \\
\hline- & - & 26 & 3.8 & 20 & 4.5 & 19. & 2.4 & 1738 \\
\hline-- & -- & 54 & 6.6 & 42 & 8.0 & 39. & 4.2 & 1739 \\
\hline- & -- & 2.0 & - & 1.9 & - & 1.8 & - & 1740 \\
\hline- & -- & .9 & .7 & 2.0 & .07 & 1.9 & .06 & 1741 \\
\hline- & -- & 2.3 & 1.0 & 4.2 & 1.0 & 3.8 & .9 & 1742 \\
\hline 2.2 & 1.8 & -- & -- & 5.1 & 1.1 & $\cdots$ & -- & 399-MG \\
\hline$<2.0$ & -- & - & - & 2.5 & .9 & -. & - & 1000 \\
\hline$<1.0$ & -- & -- & -- & 2.4 & .9 &.- & -- & 1001 \\
\hline$<3.0$ & -- & - & - & 1.3 & .8 & -- & -- & 1002 \\
\hline$<4.0$ & - & -- & -- & 10 & 2.0 & -- & -- & 1003 \\
\hline$<2.0$ & -- & -- & - & 11 & 1.0 & - & -- & 1004 \\
\hline$<1.0$ & - & -- & -- & 1.9 & .7 & -- &.. & $88 . Y O$ \\
\hline- & -- & 1.2 & .8 & 2.7 & .8 & 2.5 & .7 & 351 \\
\hline$<.9$ & - & - & -- & 2.1 & .7 & - & - & 371 \\
\hline- & - & 3.0 & 1.1 & 2.9 & 1.0 & 2.5 & .7 & 650 \\
\hline 2.4 & .9 & -- & -- & 3.1 & .7 & -- & -- & 792 \\
\hline 9.6 & 2.0 & - & -- & 21 & 2.0 & -- & - & 1148 \\
\hline 7.0 & 1.6 & - & -- & 15 & 1.0 & -- & - & \\
\hline 1.4 & 1.2 & -- & -- & 4.3 & 1.0 & -- & - & 1149 \\
\hline$<1.0$ & -- & -- & -- & 1.2 & .7 & -- & -- & 1150 \\
\hline$<2.0$ & - & - & - & 1.6 & 1.0 & -- & -. & 1151 \\
\hline$<2.0$ & - & - & - & $<1.0$ & - & -- & - & 1152 \\
\hline$<2.0$ & - & - & - & 3.7 & 1.0 & -- & - & 1153 \\
\hline 1.1 & .9 & - & - & 2.1 & .8 & -- & - & 1154 \\
\hline$<.9$ & -- & -- & - & 1.3 & .7 & -- & - & 1155 \\
\hline$<.8$ & -- & - & -- & 2.9 & .8 & -- & - & 1156 \\
\hline 17 & 3.0 & - & -- & 23 & 2.0 & -- & - & 1157 \\
\hline$<1.0$ & -- & - & -- & 4.6 & 1.0 & -- & - & 1158 \\
\hline$<2.0$ & - & - & -- & 2.3 & .9 & -- & - & 1159 \\
\hline$<1.0$ & - & - & -- & 1.6 & .7 & - & - & 1160 \\
\hline$<.1$ & - & - & .. & 3.2 & .9 & - & - & 1161 \\
\hline
\end{tabular}


Table 22. Chemical analyses of radionuclides in ground water in the Chickies Quartzite and adjacent geologic units. Geologic unit codes are explained at the beginning of table 20. Counting or analytical error values for each sample give counting or analytical uncertainty at the $2 \sigma$ or 95 -percent-confidence level.--Continued

\begin{tabular}{|c|c|c|c|c|c|c|c|c|c|}
\hline $\begin{array}{l}\text { USGS } \\
\text { well } \\
\text { number }\end{array}$ & $\begin{array}{l}\text { Geo- } \\
\text { logic } \\
\text { unit }\end{array}$ & Date & $\begin{array}{l}\text { Radon- } \\
222, \\
\text { total } \\
(\mathrm{pCi} / \mathrm{L})\end{array}$ & $\begin{array}{l}\text { Radium- } \\
226, \\
\text { dis- } \\
\text { solved, } \\
\text { radon } \\
\text { method } \\
(\mathrm{pCi} / \mathrm{L})\end{array}$ & $\begin{array}{l}\text { Radium- } \\
226, \\
2-\sigma \\
\mathrm{CE} \\
(\mathrm{pCi} / \mathrm{L})\end{array}$ & $\begin{array}{l}\text { Radium- } \\
228, \\
\text { dis- } \\
\text { solved } \\
\text { (pCi/L } \\
\text { as } \\
\text { Ra-228) }\end{array}$ & $\begin{array}{l}\text { Radium- } \\
228, \\
2-\sigma \\
\text { CE } \\
(\mathrm{pCi} / \mathrm{L})\end{array}$ & $\begin{array}{l}\text { Uranium, } \\
\text { natural, } \\
\text { dis- } \\
\text { solved } \\
(\mu \mathrm{g} / \mathrm{L} \\
\text { as } U \text { ) }\end{array}$ & $\begin{array}{c}\text { Uranium, } \\
2-\sigma \\
\mathrm{AE} \\
(\mu \mathrm{g} / \mathrm{L})\end{array}$ \\
\hline YO-1162 & 377HRPR & $07-21-87$ & 2,400 & 0.45 & 0.09 & $<0.60$ & -- & $<0.05$ & -- \\
\hline 1163 & $377 \mathrm{CCKS}$ & $07-21-87$ & 1,100 & .73 & .09 & .66 & 0.04 & $<.05$ & - \\
\hline 1164 & $377 \mathrm{CCKS}$ & $07-22-87$ & 6,800 & $<.10$ & -- & 1.1 & .4 & $<.05$ & - \\
\hline 1165 & $377 \mathrm{CCKS}$ & $07-22-87$ & 11,500 & .97 & .01 & 8.7 & .9 & .09 & 0.01 \\
\hline 1166 & $377 \mathrm{CCKS}$ & $07-23-87$ & 5,000 & 3.6 & .1 & 8.5 & 1.0 & .20 & .03 \\
\hline 1167 & 377HRPR & $07-23-87$ & 3,500 & $<.20$ & - & $<.50$ & -- & $<.05$ & -- \\
\hline 1168 & 377VNTG & 07-23-87 & 460 & $<.20$ & -. & $<.50$ & -- & $<.05$ & -- \\
\hline 1172 & $377 \mathrm{CCKS}$ & $08-11-88$ & 12,700 & 1.2 & .2 & 2.1 & 1.0 & .06 & .01 \\
\hline 1175 & $377 \mathrm{CCKS}$ & 08-08-88 & 1,600 & .44 & .08 & $<1.0$ & -- & .01 & .01 \\
\hline 1176 & $377 \mathrm{CCKS}$ & $08-09-88$ & 2,400 & .31 & .05 & $<1.0$ & -- & .01 & .01 \\
\hline 1177 & $377 \mathrm{CCKS}$ & $08-09-88$ & 3,100 & .10 & .02 & $<1.0$ & - & .01 & .01 \\
\hline 1178 & $377 \mathrm{CCKS}$ & $08-09-88$ & 1,400 & .21 & .04 & $<1.0$ & -- & .01 & .01 \\
\hline 1179 & $377 \mathrm{CCKS}$ & $08-09-88$ & 6,000 & 12 & 2.0 & 30 & 6.0 & .67 & .10 \\
\hline 1180 & $377 \mathrm{CCKS}$ & $08-10-88$ & 11,100 & .18 & .03 & $<1.0$ & -- & .09 & .01 \\
\hline 1181 & 377CCKS & $08-10-88$ & 1,400 & .19 & .03 & $<1.0$ & -- & .02 & .01 \\
\hline 1182 & $377 \mathrm{CCKS}$ & $08-10-88$ & 1,200 & .07 & .02 & $<1.0$ & -- & .01 & .01 \\
\hline 1183 & 377CCKS & $08-11-88$ & 3,000 & 1.3 & .2 & 1.2 & .9 & .01 & .01 \\
\hline 1184 & $377 \mathrm{CCKS}$ & $09-07-88$ & 18,600 & 12 & 2.0 & 11 & 2.0 & .50 & .10 \\
\hline 1185 & 377CCKS & $09-07-88$ & 2,000 & 1.6 & .3 & 2.9 & .8 & .03 & .01 \\
\hline 1186 & $377 \mathrm{CCKS}$ & $09-07-88$ & 17,400 & 4.0 & .7 & 6.4 & 1.6 & .43 & .06 \\
\hline
\end{tabular}


Table 22. Chemical analyses of radionuclides in ground water in the Chickies Quartzite and adjacent geologic unit: Geologic unit codes are explained at the beginning of table 20. Counting or analytical error values for each sample give counting or analytical uncertainty at the $2 \sigma$ or 95 -percent-confidence level.--Continued

\begin{tabular}{|c|c|c|c|c|c|c|c|c|}
\hline $\begin{array}{l}\text { Gross } \\
\text { alpha, } \\
\text { dis- } \\
\text { solved } \\
\text { (pCi/L } \\
\text { as } \\
\text { U-Nat) }\end{array}$ & $\begin{array}{c}\text { Gross } \\
\text { alpha, } \\
2-\sigma \\
\text { CE } \\
\text { (pCi/L } \\
\text { as } \\
\text { U-Nat) }\end{array}$ & $\begin{array}{c}\text { Gross } \\
\text { alpha, } \\
\text { dis- } \\
\text { solved } \\
\text { ( } \mu \text { g/L } \\
\text { as } \\
\text { U-Nat) }\end{array}$ & $\begin{array}{c}\text { Gross } \\
\text { alpha, } \\
2-\sigma \\
\text { CE } \\
(\mu g / L \\
\text { as } \\
\text { U-Nat) }\end{array}$ & $\begin{array}{l}\text { Gross } \\
\text { beta, } \\
\text { dis- } \\
\text { solved } \\
\text { (pCiL } \\
\text { as } \\
\text { Cs-137) }\end{array}$ & $\begin{array}{c}\text { Gross } \\
\text { beta, } \\
2-\sigma \\
\mathrm{CE} \\
\text { (pCi/L } \\
\text { as } \\
\text { CS-137) }\end{array}$ & $\begin{array}{l}\text { Gross } \\
\text { beta, } \\
\text { dis- } \\
\text { solved } \\
\text { (pCiL } \\
\text { as Sr/ } \\
\text { Yt-90) }\end{array}$ & $\begin{array}{c}\text { Gross } \\
\text { beta, } \\
2-\sigma \\
\text { CE } \\
\text { (pCiL } \\
\text { as } \\
\text { SR/YT-90) }\end{array}$ & $\begin{array}{l}\text { USGS } \\
\text { well } \\
\text { number }\end{array}$ \\
\hline$<1.0$ & -- & -- & -. & 2.2 & 0.7 & & -. & 1162-Y? \\
\hline 1.2 & 0.8 & - & -- & 2.5 & .7 & -- & -- & 1163 \\
\hline 1.3 & 1.0 & -- & .. & 3.2 & .8 & -- & .- & 1164 \\
\hline 5.7 & 1.9 & - & -- & 11 & 1.0 & -- & -- & 1165 \\
\hline 5.4 & 2.1 & - & -- & 18 & 2.0 & -- & - & 1166 \\
\hline$<1.0$ & -- & .. & -- & 5.5 & 1.0 & -. & -- & 1167 \\
\hline 2.0 & - & - & - & 1.6 & .9 & - & - & 1168 \\
\hline -. & -- & 7.6 & 1.7 & 8.9 & 2.0 & 8.4 & 1.3 & 1172 \\
\hline- & - & 1.8 & .8 & 2.0 & .8 & 2.0 & .6 & 1175 \\
\hline- & -- & 2.5 & 1.0 & 4.6 & 1.0 & 4.2 & .9 & 1176 \\
\hline - & -- & 1.0 & .7 & 1.9 & .8 & 1.8 & .6 & 1177 \\
\hline .- & -- & 1.4 & .7 & 2.2 & .7 & 2.1 & .7 & 1178 \\
\hline- & -- & 120 & 13 & 79 & 9.0 & 70 & 8.0 & 1179 \\
\hline- & -- & 3.9 & 1.2 & 6.5 & 1.2 & 6.2 & 1.2 & 1180 \\
\hline -. & -. & 1.4 & .8 & 1.5 & .7 & 1.4 & .6 & 1181 \\
\hline- & -- & $<.4$ & -- & 1.1 & .6 & 1.1 & .5 & 1182 \\
\hline- & -- & 6.8 & 2.1 & 3.7 & 1.1 & 3.1 & .8 & 1183 \\
\hline-- & -- & 53 & 7.0 & 30 & 6.0 & 28 & 4.0 & 1184 \\
\hline -- & - & 8.4 & 1.8 & 7.1 & 1.7 & 6.7 & 1.2 & 1185 \\
\hline -- & -. & 22 & 3.0 & 15 & 3.0 & 14 & 2.0 & 1186 \\
\hline
\end{tabular}


APPENDIX--Caliper and natural gamma logs for wells in the Chickies Que tzite, southeastern Pennsylvania 
GEOPHYSICAL LOGS

In the Barren Hills, Chester County. $\mathrm{Pa}$.

Chickies Quartzite: Light- to dark-colored sandstone and quartzite; phyllitic quartzite; "Hellam conglomerate"

$$
\begin{array}{r}
\mathrm{CH}-3122 \\
3131 \\
3133 \\
3160 \\
3166 \\
3188 \\
3189 \\
3213 \\
3219 \\
3305 \\
3315
\end{array}
$$

On Welsh Mountain and Gap Hill. Lancaster County. Pa.

Chickies Quartzite: White to tan quartzite and sandstone; gray quartzite

$$
\begin{array}{r}
\text { LN- } 1702 \\
1703 \\
1713 \\
1715 \\
1716
\end{array}
$$

In the Hellam Hills. York County. $\mathrm{Pa}$.

Chickies Quartzite: "Hellam conglomerate"

YO- 1172

125 


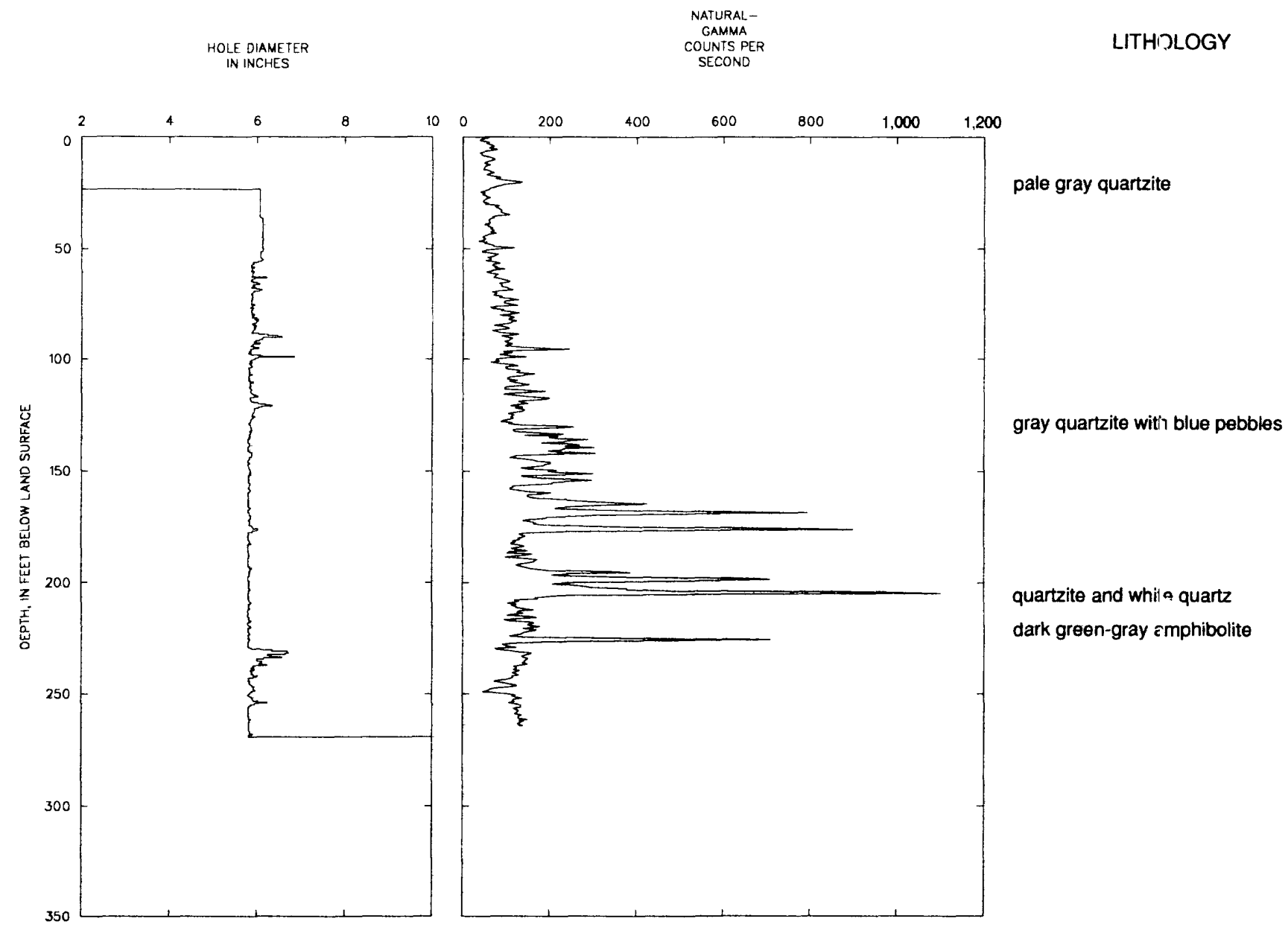

Caliper and natural gamma logs for well CH-3122 in the Chickies Quartzite, southeastern Pennsylvania. 


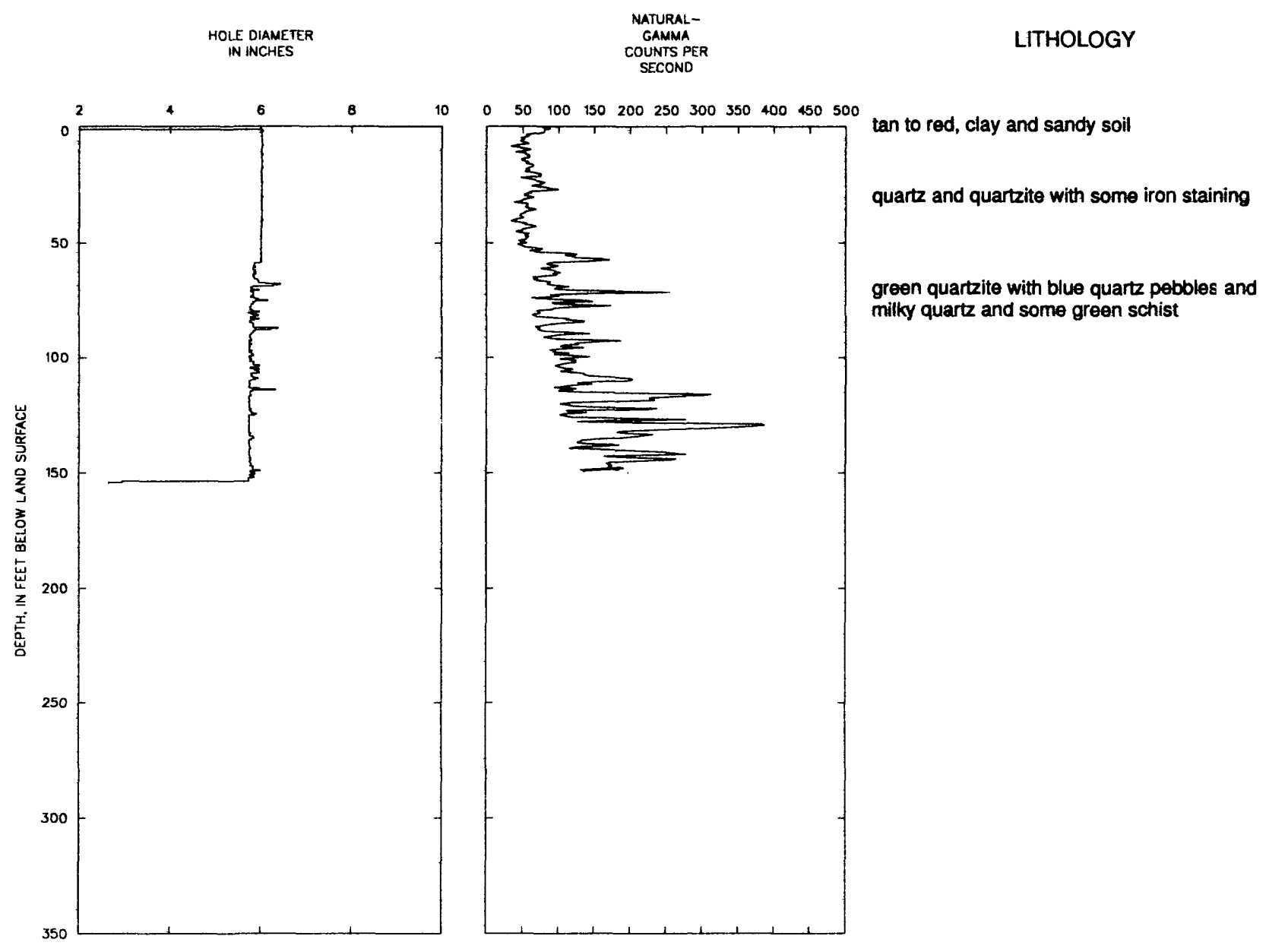

Caliper and natural gamma logs for well CH-3131 in the Chickies Quartzite, southeastern Pennsylvania. 


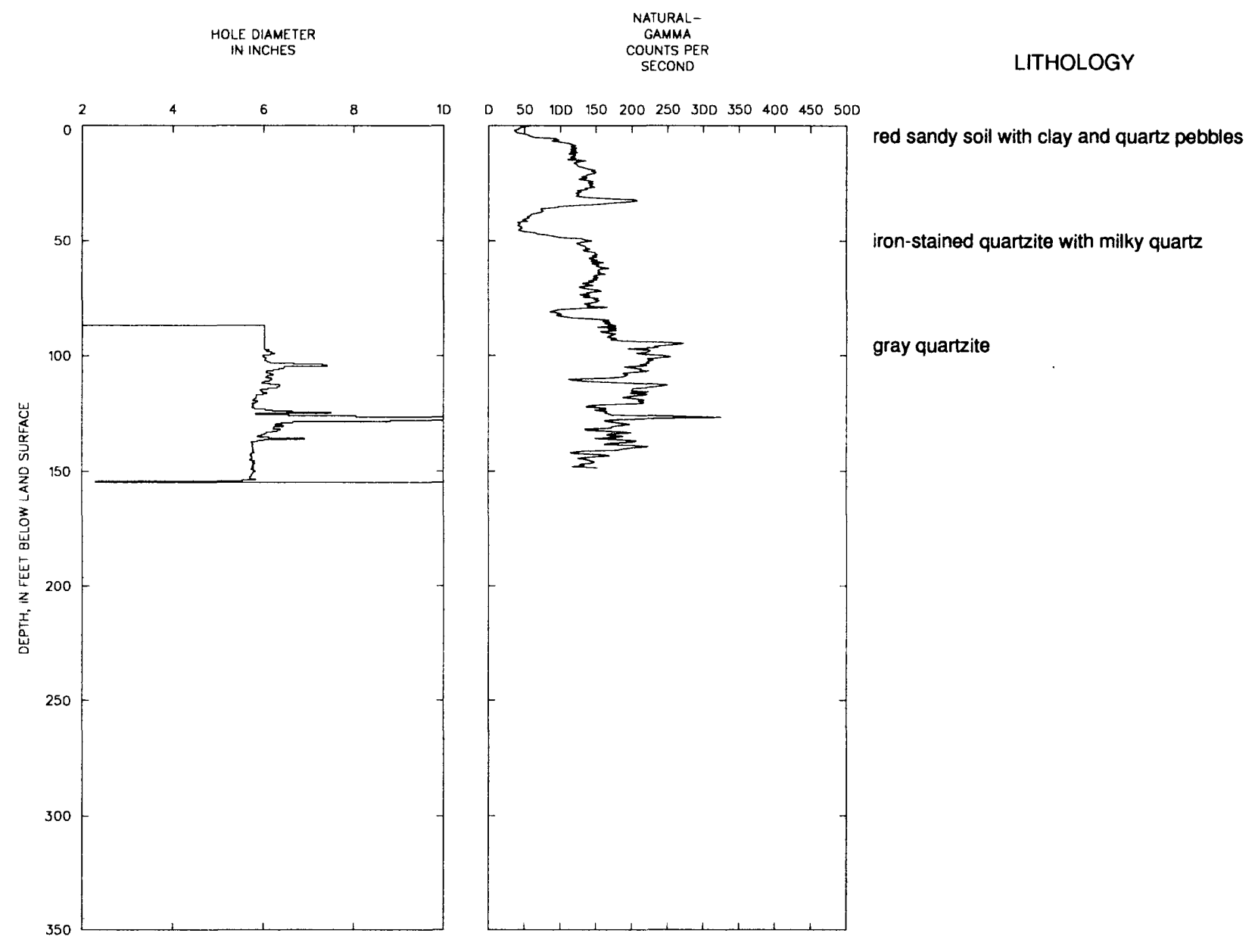

Caliper and natural gamma logs for well $\mathrm{CH}-3133$ in the Chickies Quartzite, southeastern Pennsylvania. 

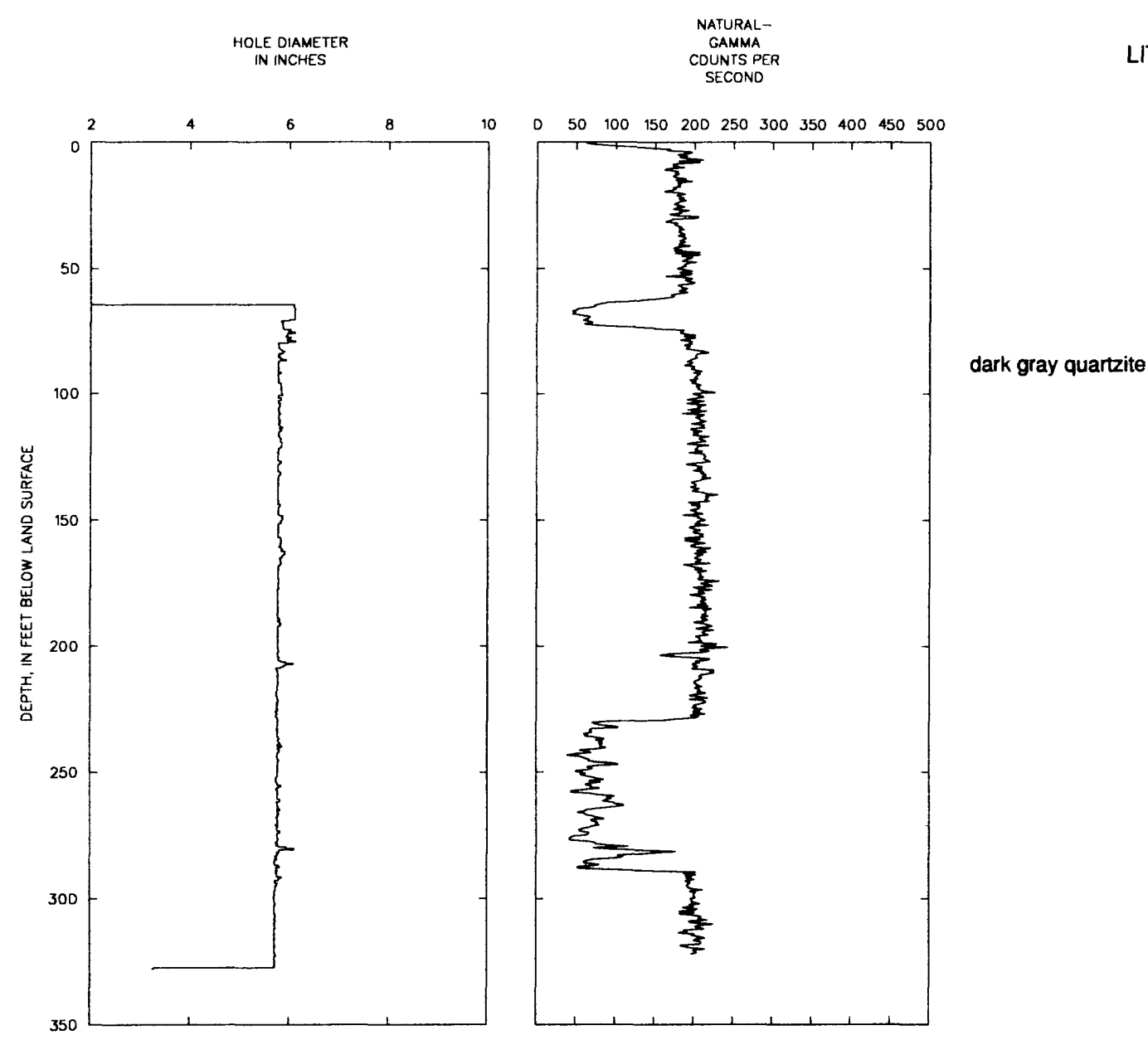

Caliper and natural gamma logs for well CH-3160 in the Chickies Quartzite, southeastern Pennsylvania. 


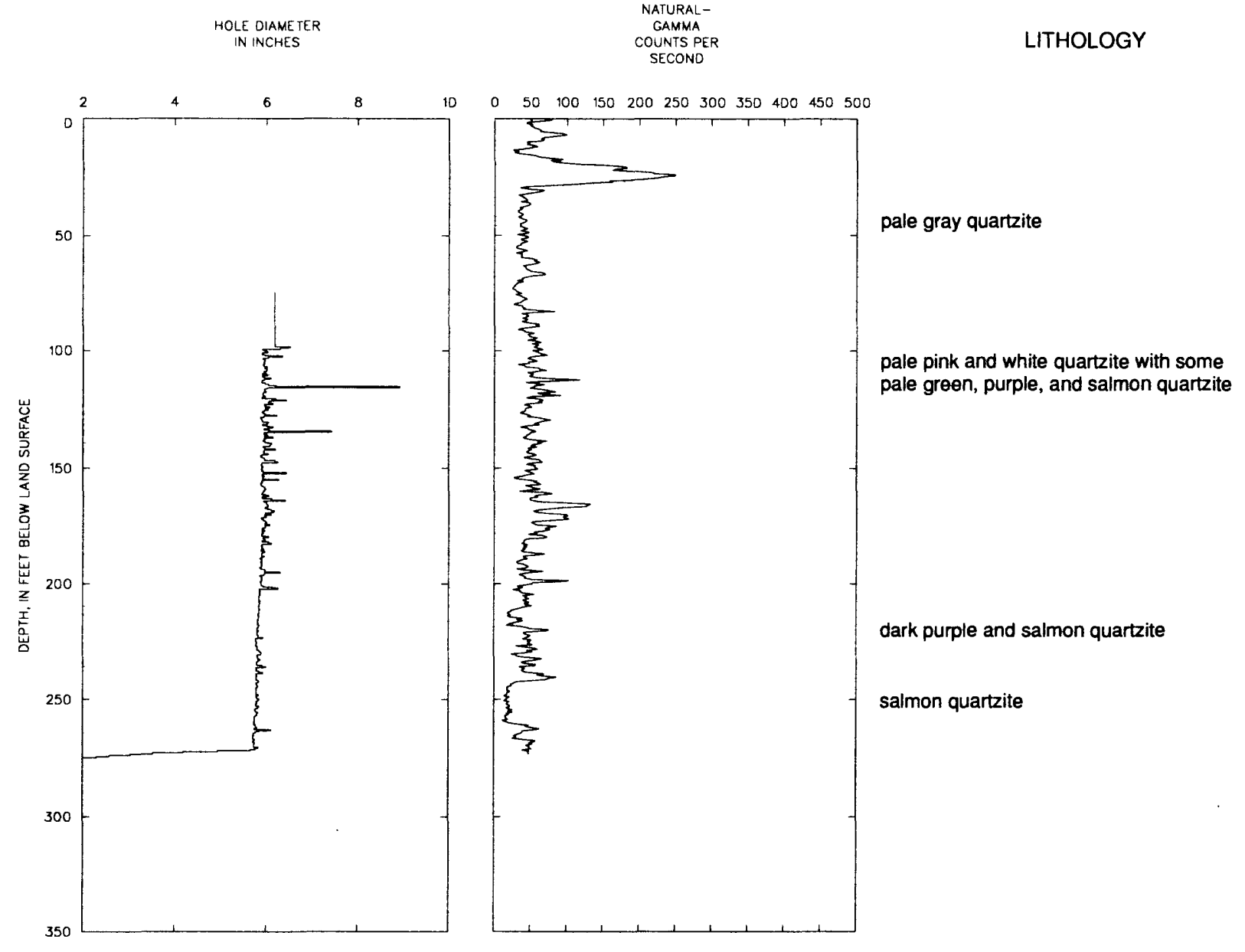

Caliper and natural gamma logs for well $\mathrm{CH}-3166$ in the Chickies Quartzite, southeastern Pennsylvania. 


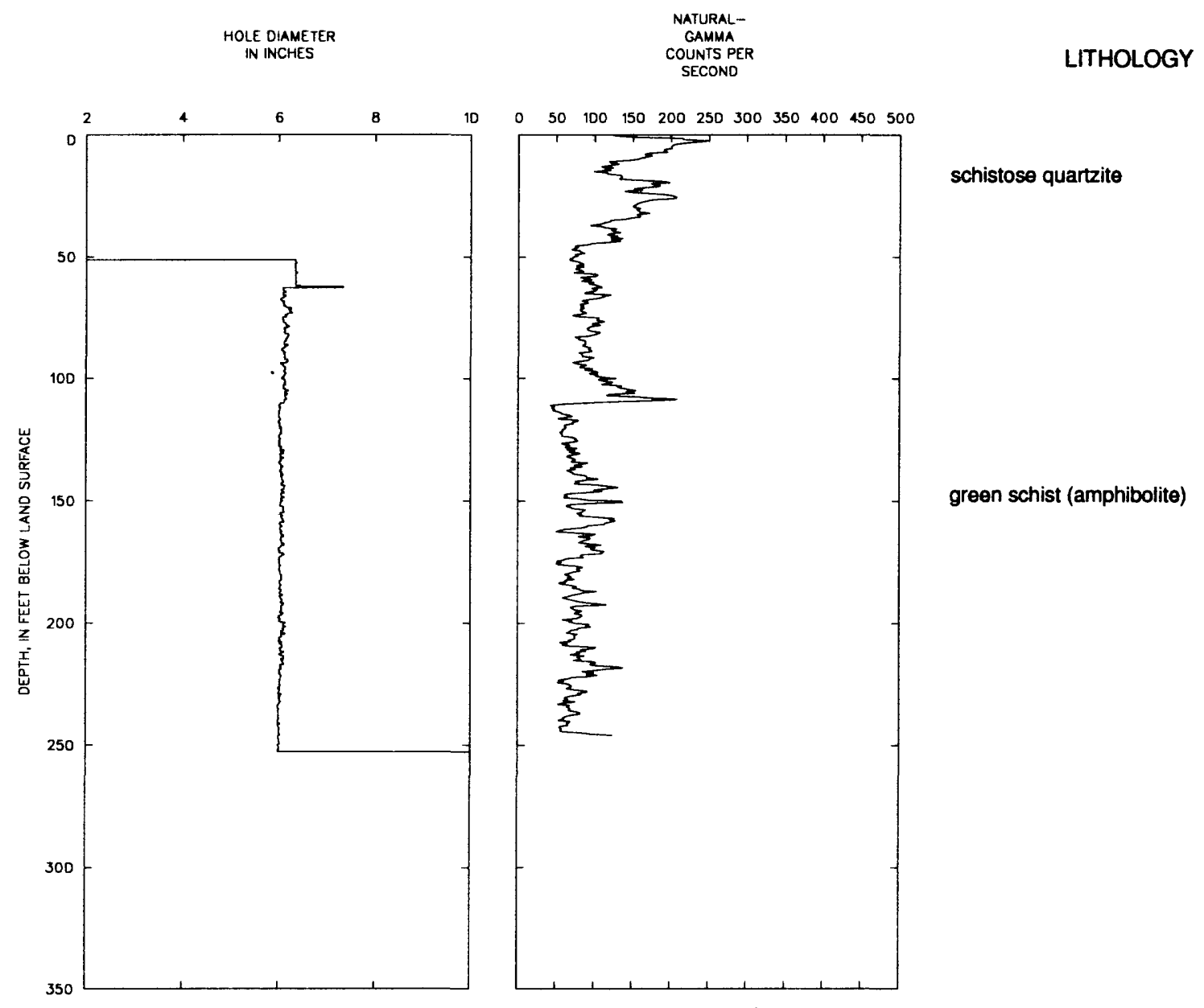

Caliper and natural gamma logs for well CH-3188 in the Chickies Quartzite, southeastern Pennsylvania. 


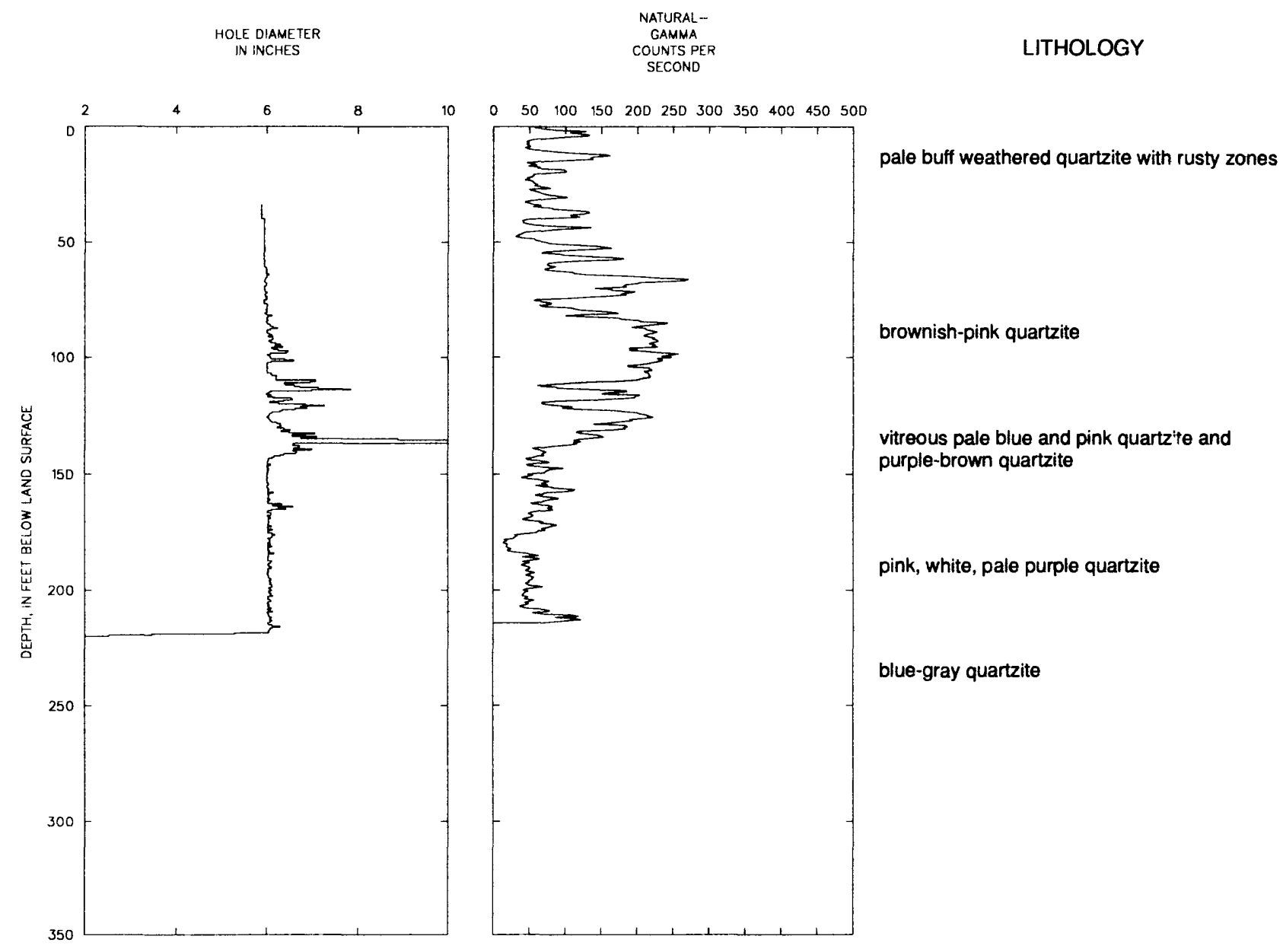

Caliper and natural gamma logs for well CH-3189 in the Chickies Quartzite, southeastern Pennsylvania. 


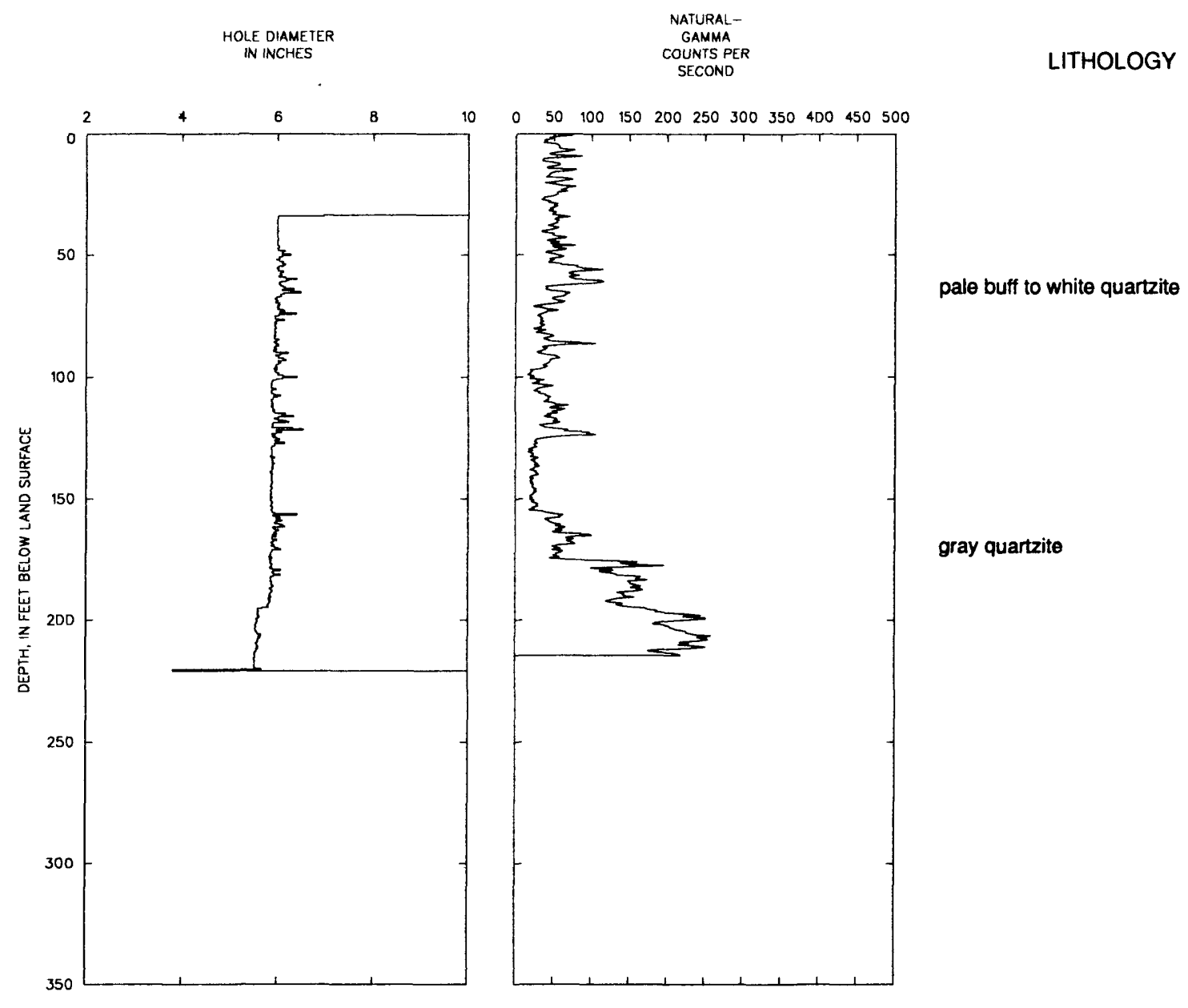

Caliper and natural gamma logs for well $\mathrm{CH}-3213$ in the Chickies Quartzite, southeastern Pennsylvania. 


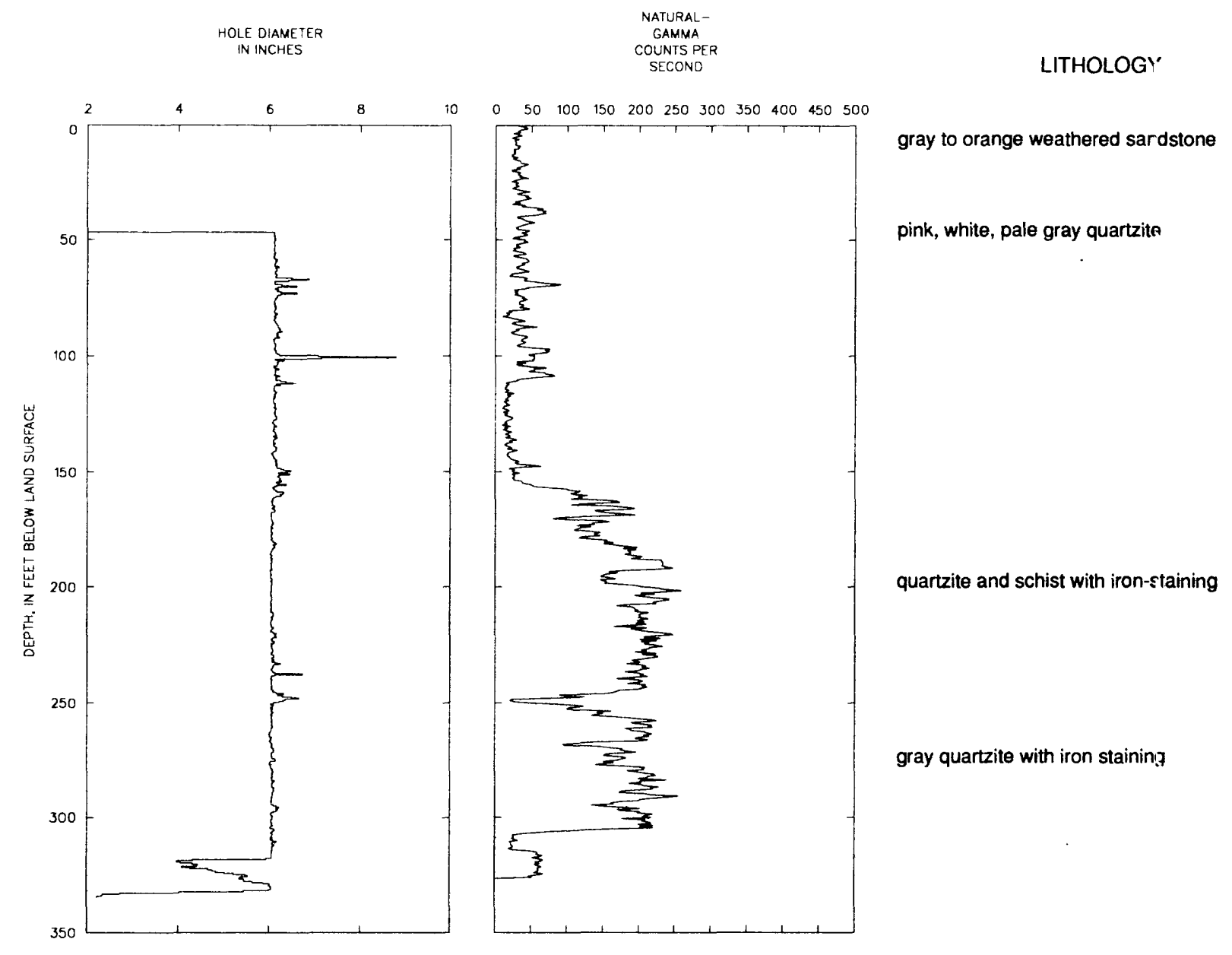

Caliper and natural gamma logs for well CH-3219 in the Chickies Quartzite, southeastern Pennsylvania. 

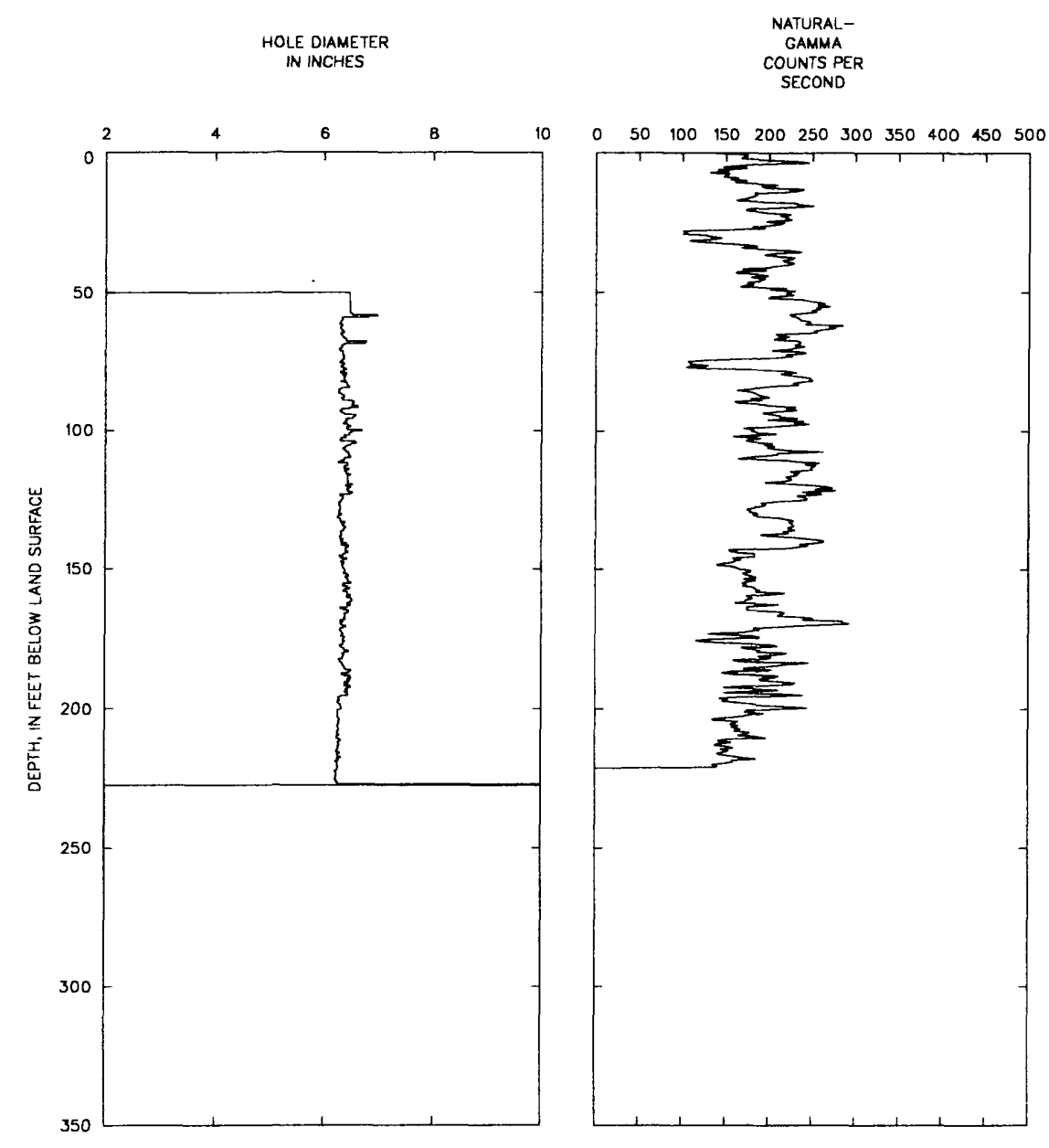

medium/dark gray quartzite

Caliper and natural gamma logs for well CH-3305 in the Chickies Quartzite, southeastern Pennsylvania. 


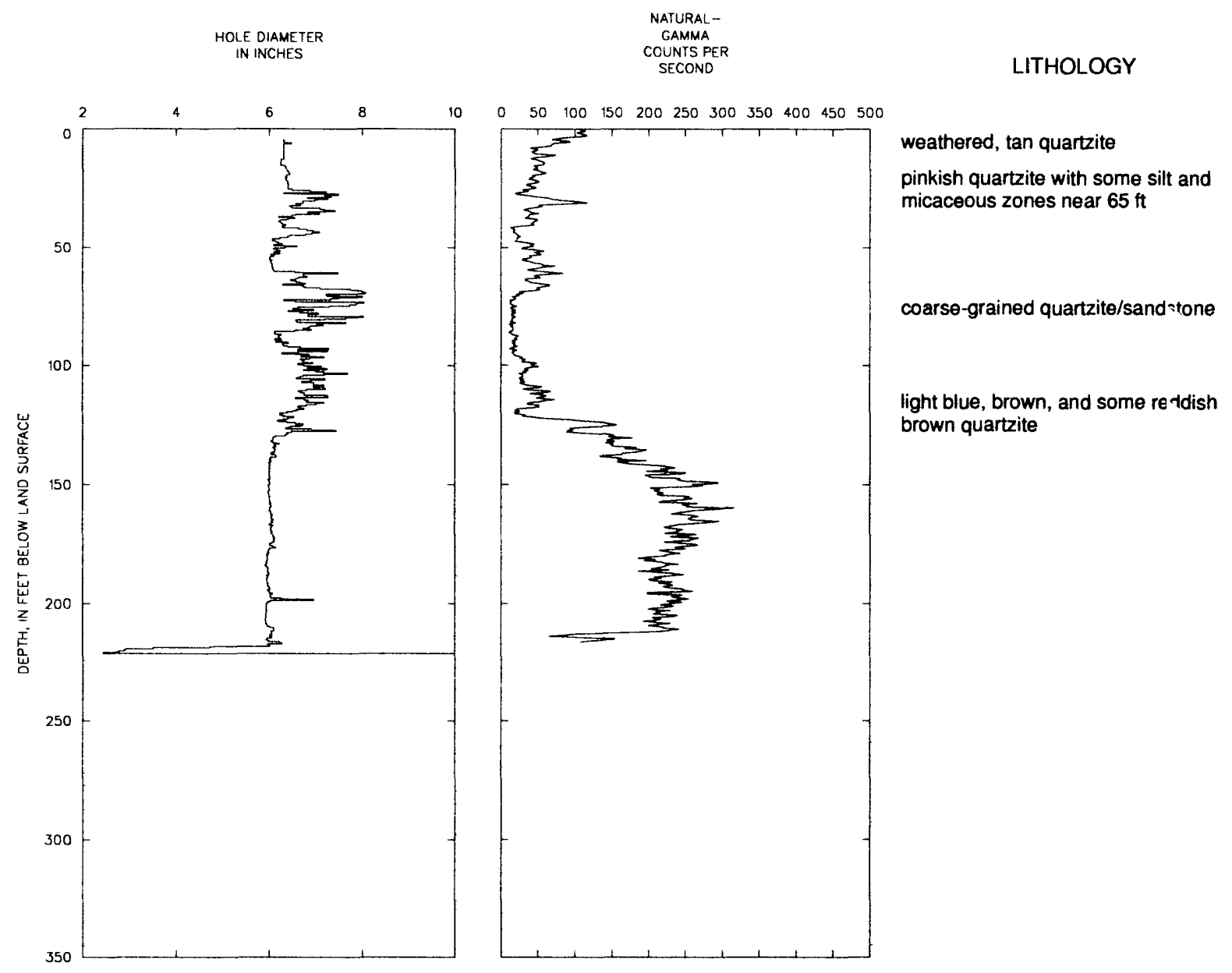

Caliper and natural gamma logs for well $\mathrm{CH}-3315$ in the Chickies Quartzite, southeastern Pennsylvania. 


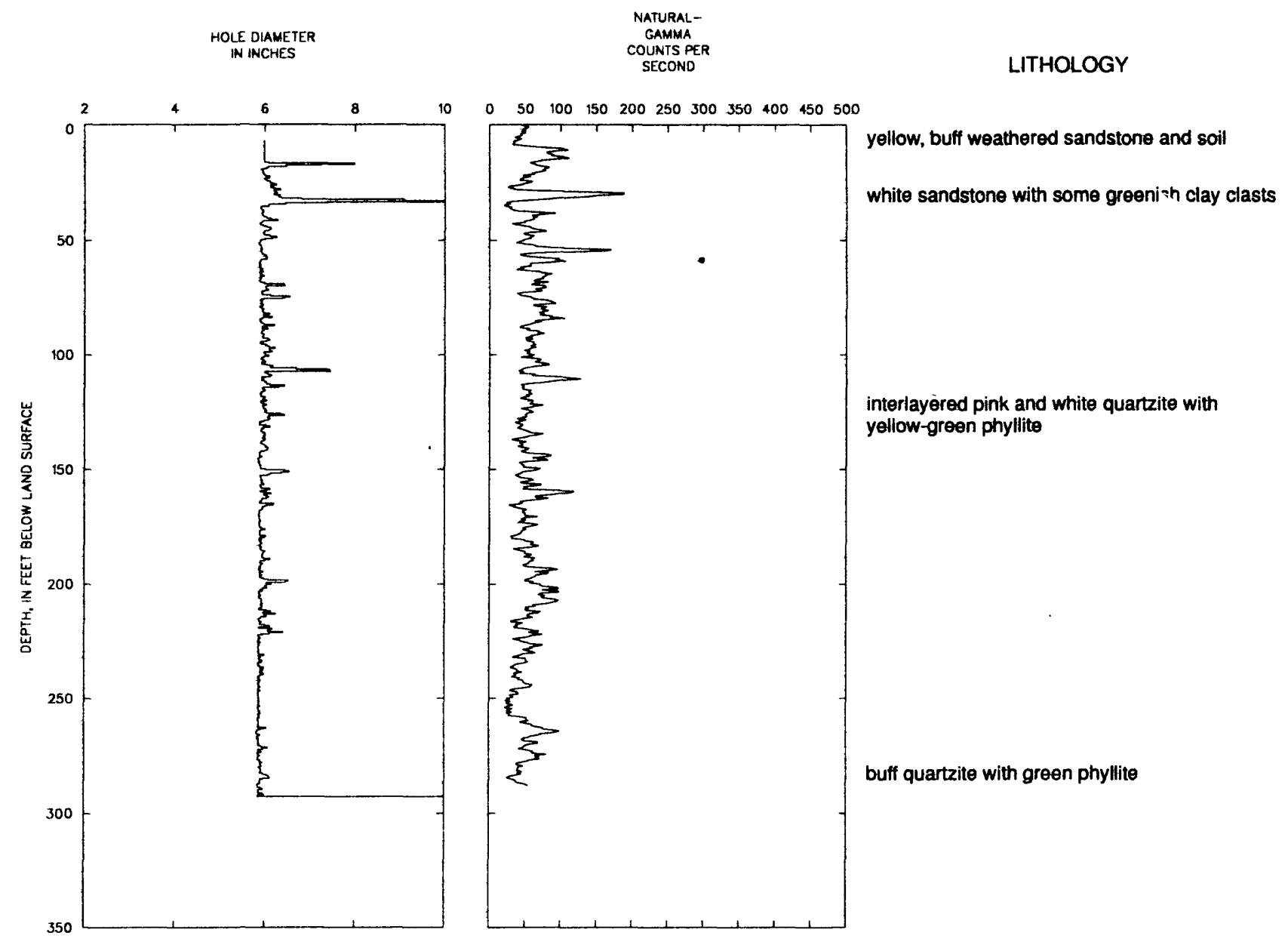

Caliper and natural gamma logs for well LN-1702 in the Chickies Quartzite, southeastern Pennsylvania. 


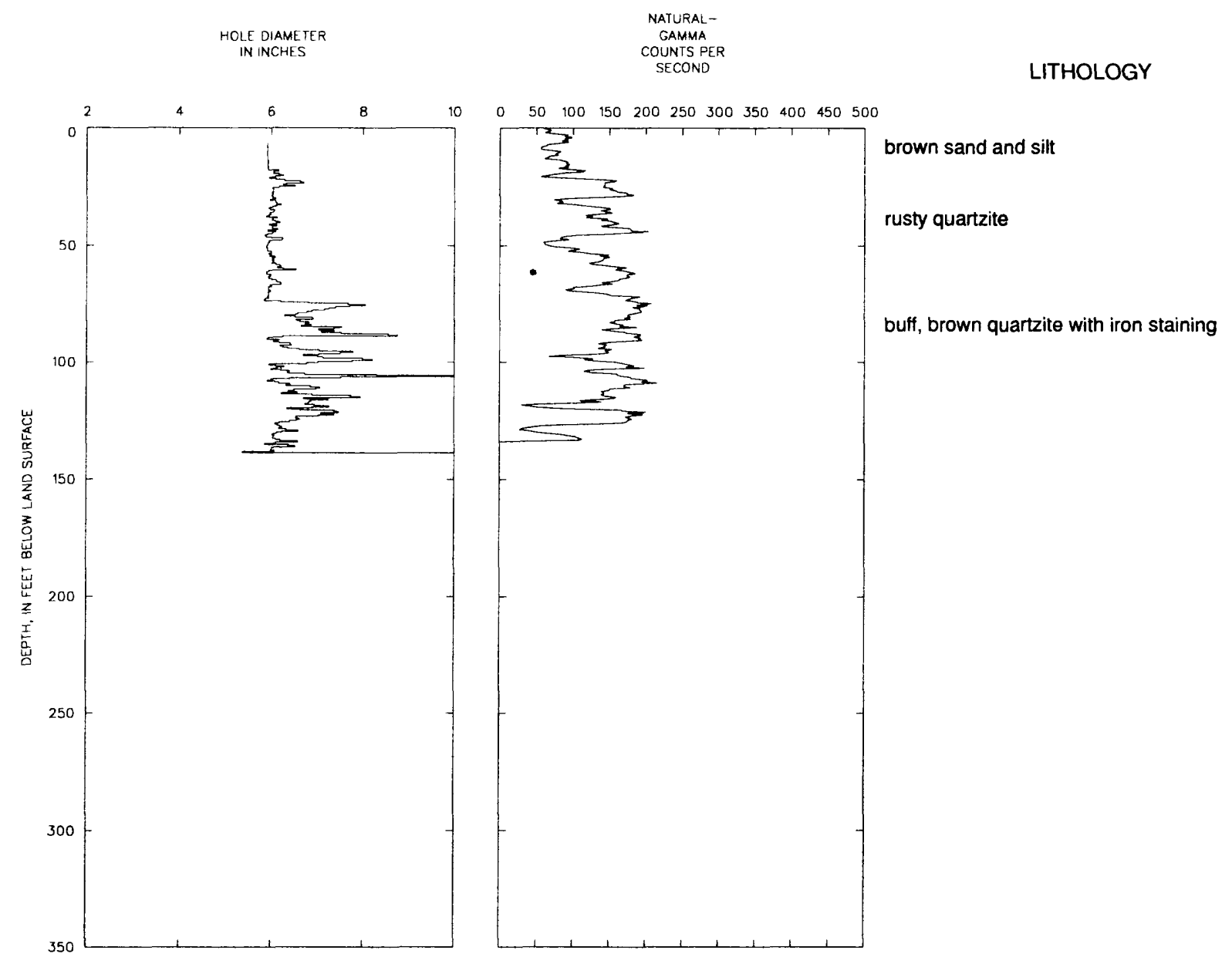

Caliper and natural gamma logs for well LN-1703 in the Chickies Quartzite, southeastern Pennsylvania. 


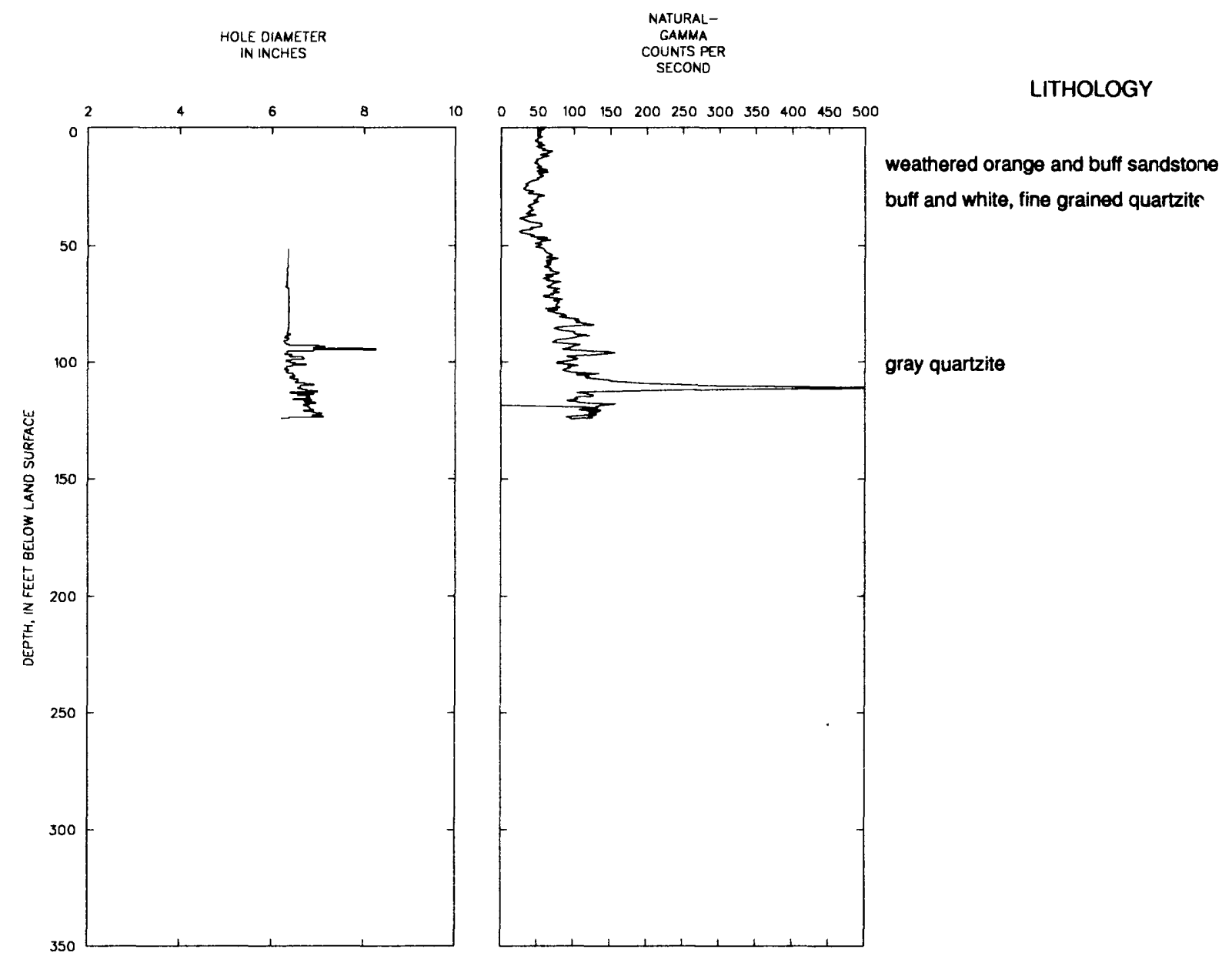

Caliper and natural gamma logs for well LN-1713 in the Chickies Quartzite, southeastern Pennsylvania. 


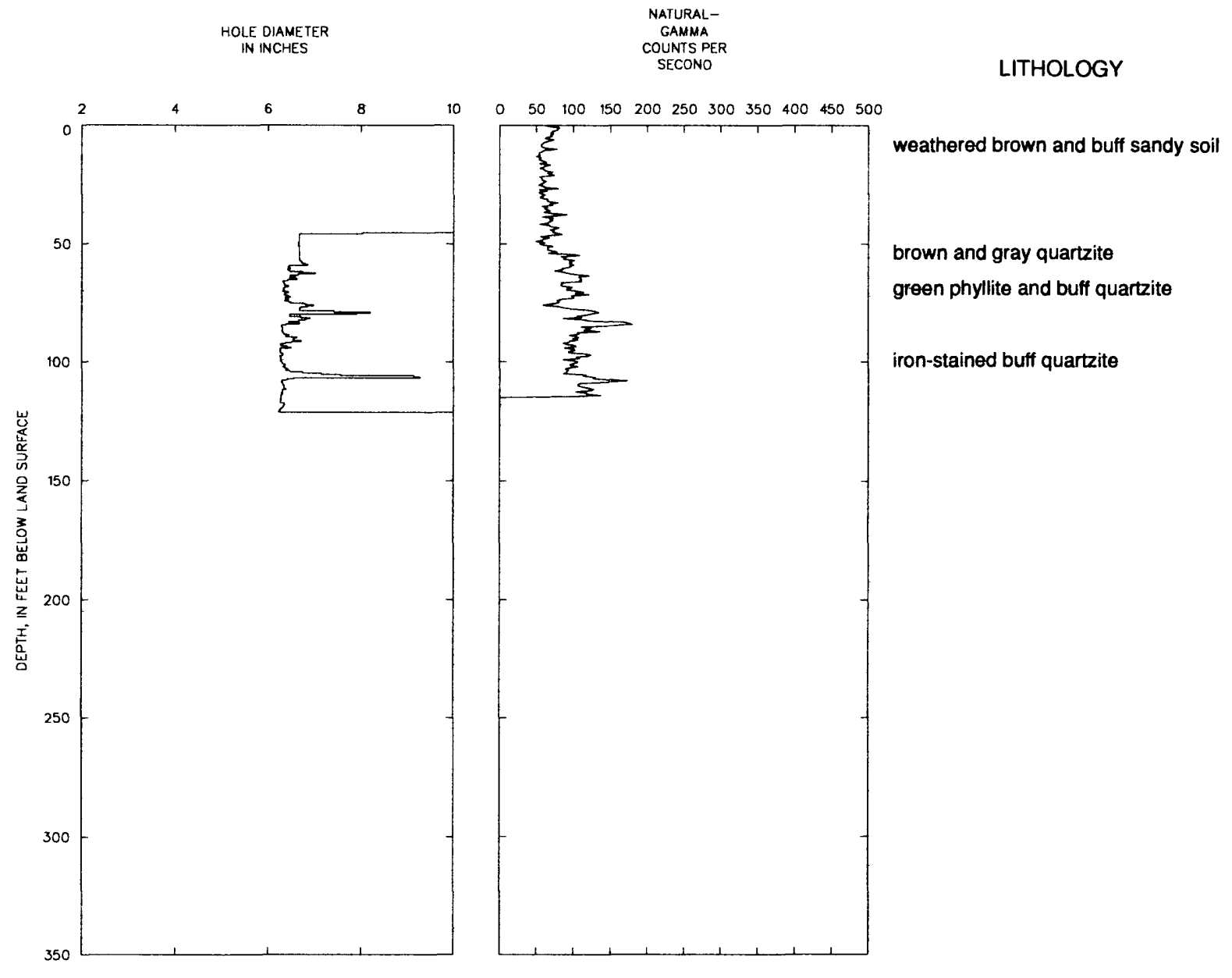

Caliper and natural gamma logs for well LN-1715 in the Chickies Quartzite, southeastern Pennsylvania. 


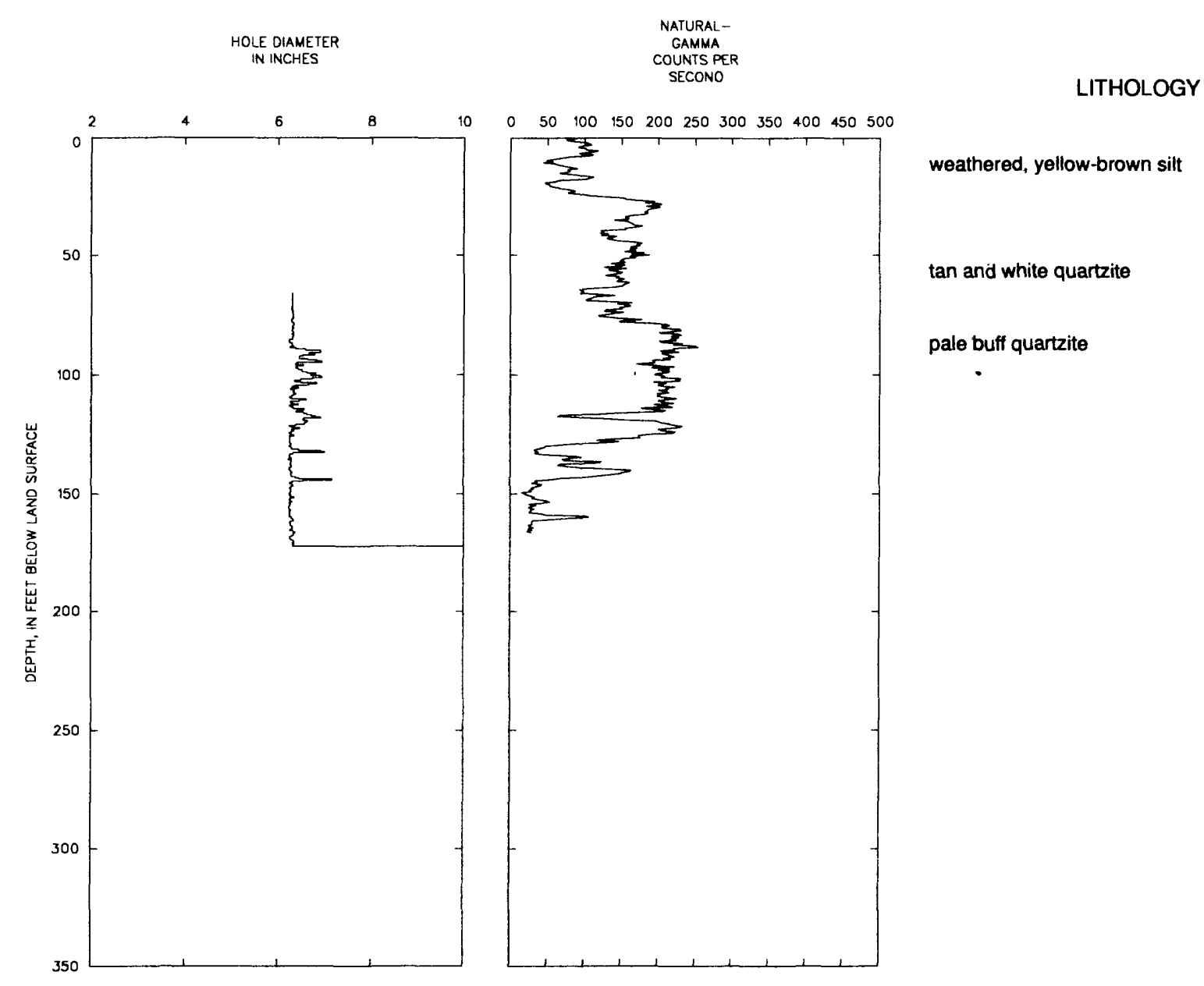

Caliper and natural gamma logs for well LN-1716 in the Chickies Quartzite, southeastern Pennsylvania. 


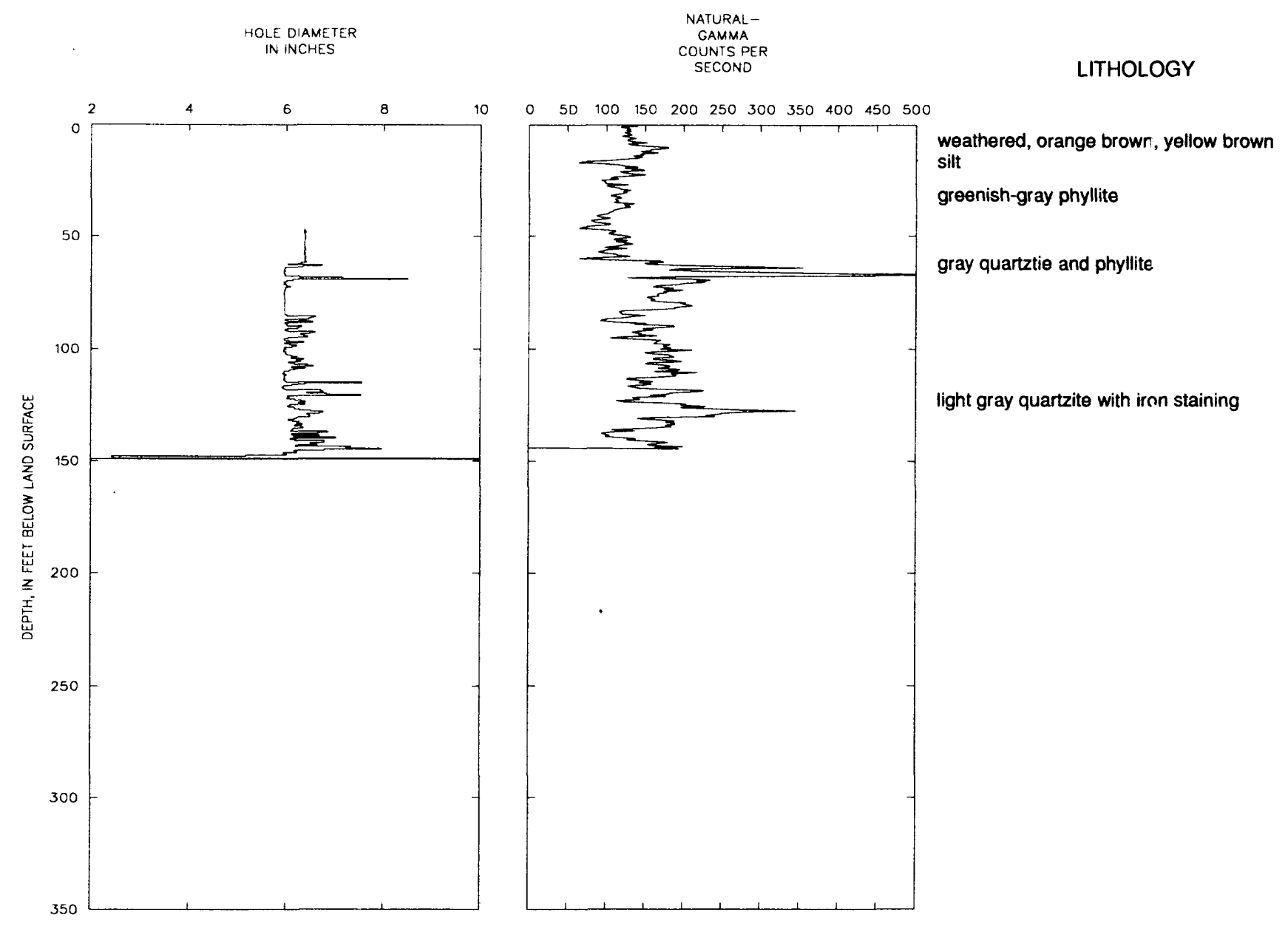

Caliper and natural gamma logs for well YO-1169 in the Chickies Quartzite, southeastern Pennsylvania. 


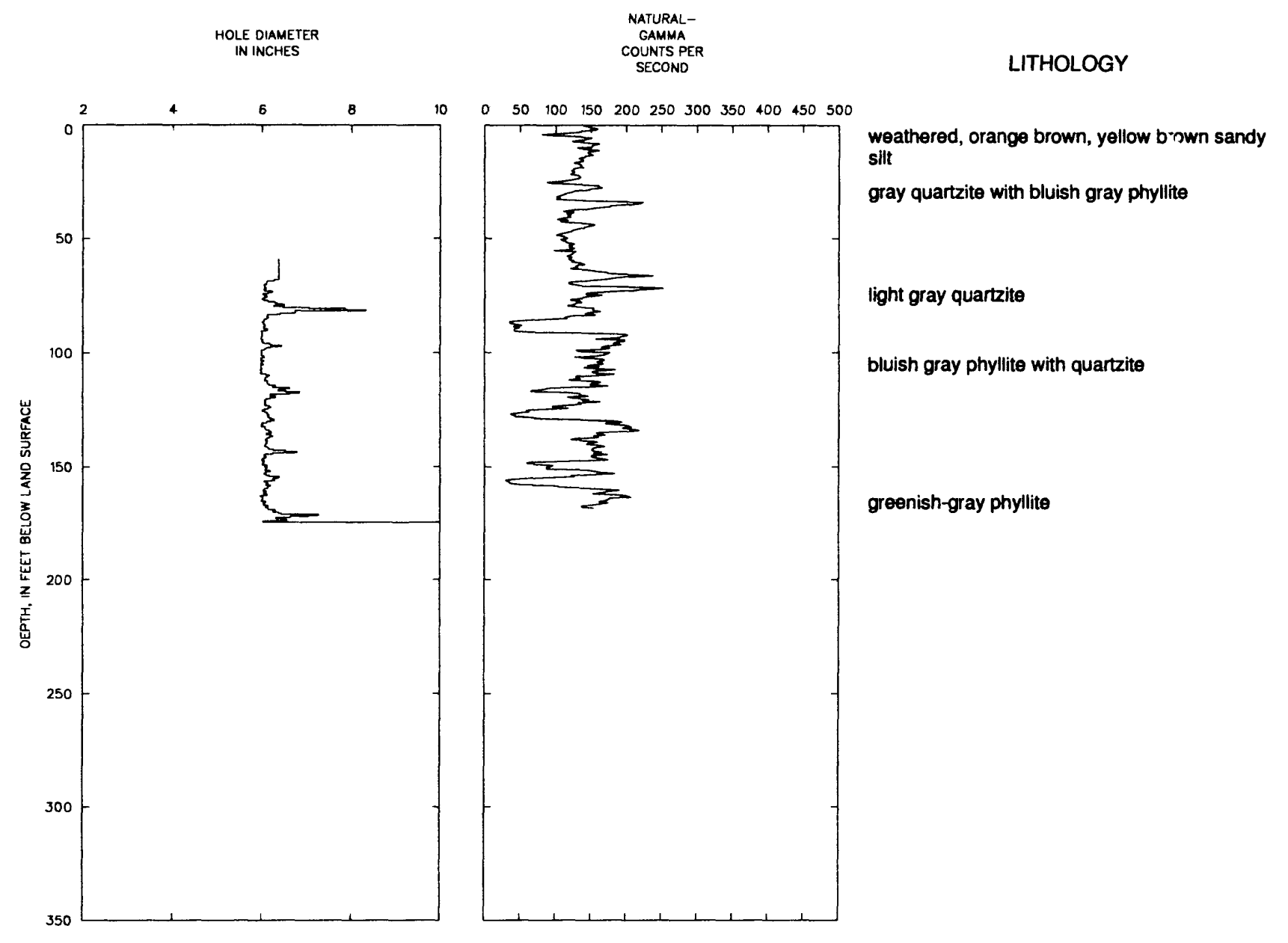

Caliper and natural gamma logs for well YO-1170 in the Chickies Quartzite, southeastern Pennsylvania. 


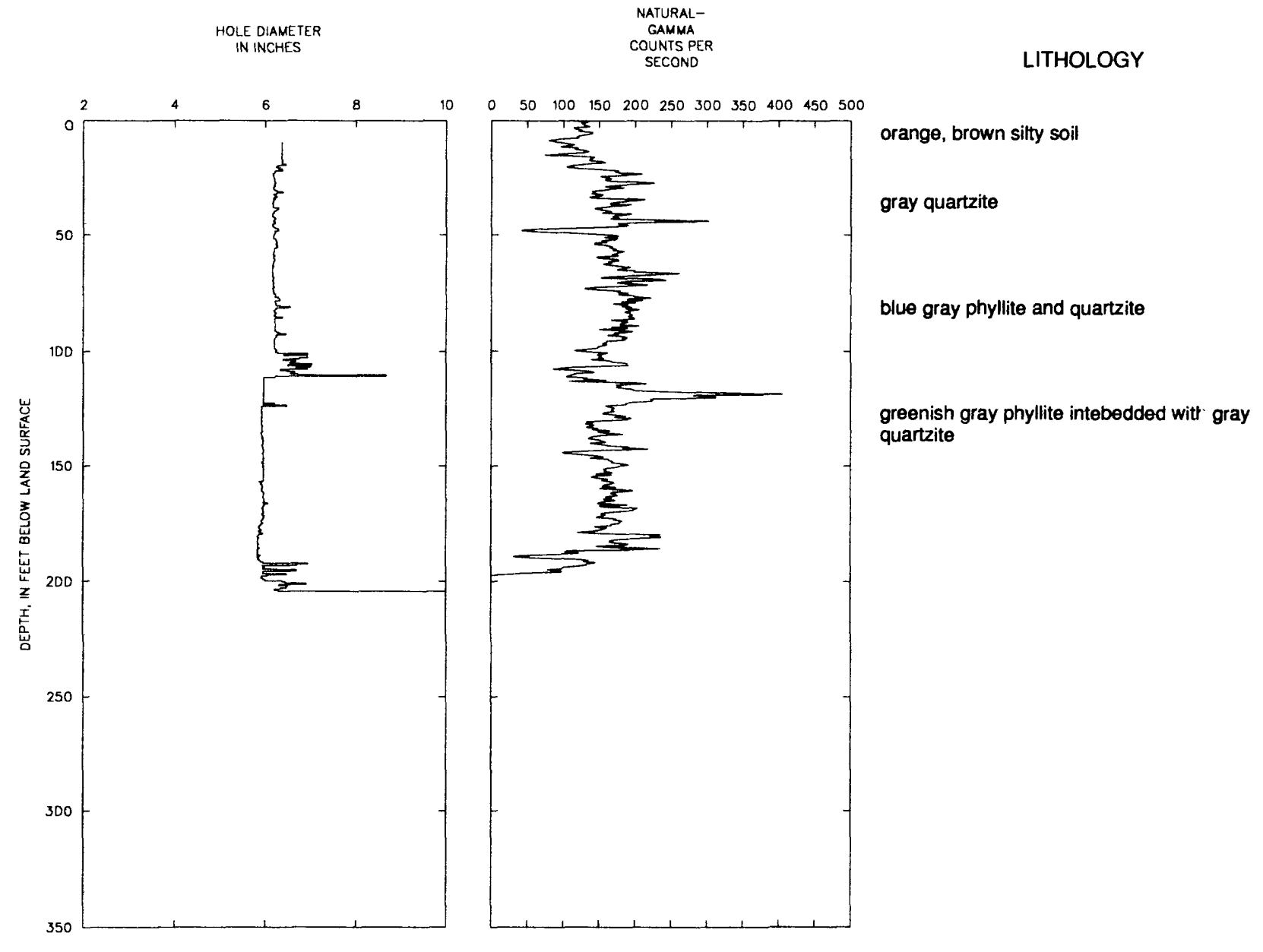

Caliper and natural gamma logs for well YO-1171 in the Chickies Quartzite, southeastern Pennsylvania. 


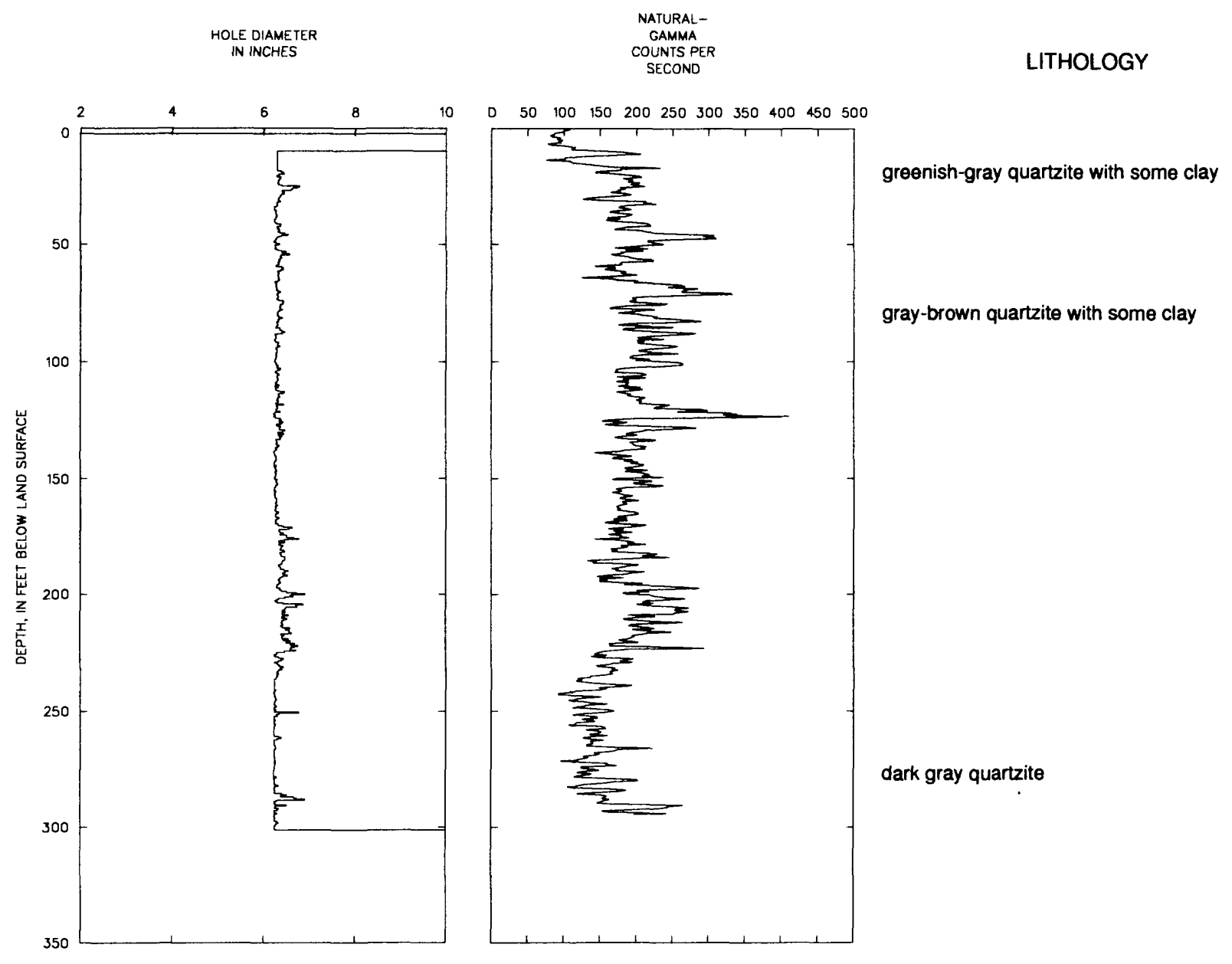

Caliper and natural gamma logs for well YO-1172 in the Chickies Quartzite, southeastern

Pennsylvania. 